\title{
An Index of Regulatory Practices for Financial Inclusion in Latin America: Enablers, Promoters, and Preventers
}

\section{Liliana Rojas-Suarez and Lucía Pacheco}

\begin{abstract}
This paper constructs an index of regulatory quality for improving financial inclusion for the purpose of assessing and comparing the quality of rules and regulations in a sample of eight Latin American countries. The index comprises 11 regulatory practices classified into three categories: those that determine the overall quality of the financial environment where providers of financial services that meet the needs of the poor operate (the enablers); those that deal with specific types of market frictions and regulate the provision of specific financial products and services (the promoters) to large segments of the population; and those that, albeit unintentionally, create distortions and barriers that adversely affect financial inclusion (the preventers). An important novelty of the index is that the assessment of individual regulatory practices not only takes into account accepted standards, but also recognizes that there are important interactions between regulations for financial inclusion as well as between these regulations and other type of government interventions. Among the countries in the sample, by mid-2017, Peru ranked first in this index, followed closely by Mexico. Chile, Colombia, Paraguay, and Uruguay obtained lukewarm results, although there were wide differences among these countries' individual results. Argentina and Brazil were the two countries with the lowest overall scores. An additional contribution of the paper is that, throughout the analysis, countries' specific areas of strengths and weakness in financial regulatory practices for improving financial inclusion are identified.
\end{abstract}

Keywords:financial inclusion, financial regulation, Latin America

JEL Codes:G21, G22, G23, I25, K21, N26, O10

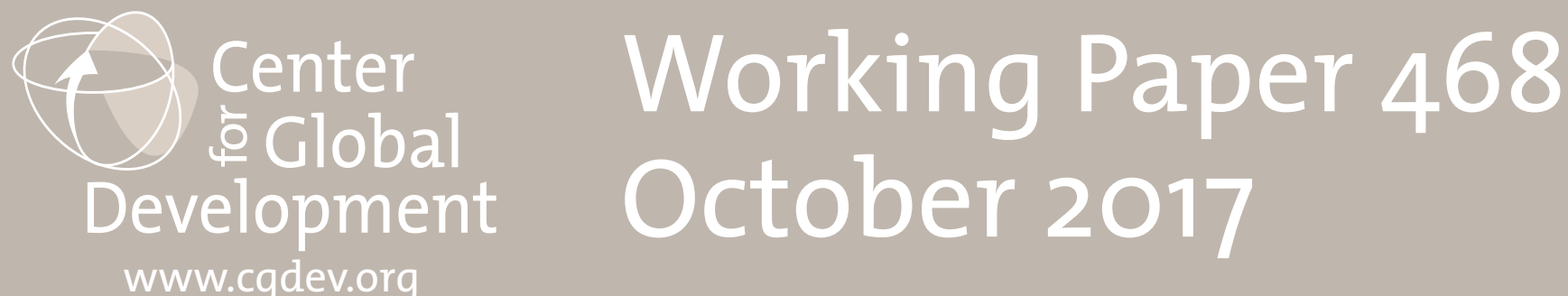




\title{
An Index of Regulatory Practices for Financial Inclusion in Latin America: Enablers, Promoters, and Preventers
}

\author{
Liliana Rojas-Suarez \\ Center for Global Development \\ Lucía Pacheco \\ BBVA
}

We are very grateful to Santiago Fernández de Lis and David Tuesta for their suggestions, comments, and invaluable insights. This paper has also benefited from the feedback and input of many BBVA research economists as well as from local experts from the Argentinian, Chilean, Colombia, Mexican, Paraguayan, Peruvian, and Uruguayan BBVA teams. We also want to thank Enestor do Santos for his insightful comments on the Brazilian framework, Carlos López Moctezuma for useful comments on this draft and Giovanni di Placido, from Fundación BBVA MicroFinanzas, for his extremely valuable feedback on the microcredit section. The authors are also grateful to an anonymous referee and to participants in a World Bank workshop for their comments. Finally, we would also wish to thank Rosa María Oliveros for her valuable research assistance. Any remaining errors are, of course, the sole responsibility of the authors. This paper was previously published by BBVA Research as Working Paper No. 17/15. The analysis, opinions, and conclusions included in this document are the property of the authors of the report and are not necessarily property of the BBVA Group.

Liliana Rojas-Suarez and Lucía Pacheco. 2017. "An Index of Regulatory Practices for Financial Inclusion in Latin America: Enablers, Promoters, and Preventers." CGD Working Paper 468. Washington, DC: Center for Global Development. https://www. cgdev.org/publication/index-regulatory-practices-financial-inclusion-latin-america

Center for Global Development 2055 L Street NW Washington, DC 20036

202.416.4000

(f) 202.416 .4050

www.cgdev.org
The Center for Global Development is an independent, nonprofit policy research organization dedicated to reducing global poverty and inequality and to making globalization work for the poor. Use and dissemination of this Working Paper is encouraged; however, reproduced copies may not be used for commercial purposes. Further usage is permitted under the terms of the Creative Commons License.

The views expressed in CGD Working Papers are those of the authors and should not be attributed to the board of directors, funders of the Center for Global Development, or the authors' respective organizations. 


\section{Contents}

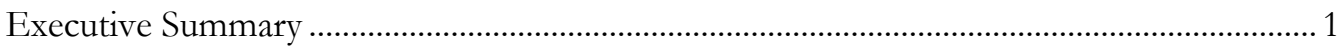

How Enabling Are the Regulatory Frameworks in Latin America? ........................................ 2

Assessing Regulations Classified as Promoters of Financial Inclusion .................................... 3

Assessing Regulations Constraining Financial Inclusion: The Preventers .............................. 7

The Overall Index of Regulations for Financial Inclusion ...................................................... 9

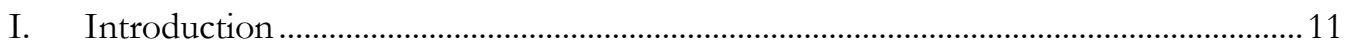

II. Assessing Regulations: Scope of the Study and Methodology.....................................12

1. Three Dimensions of Regulatory Practices Affecting Financial Inclusion: ............12

2. Constructing Indices of Regulatory Quality: The Methodology ...............................15

III. How Enabling Are the Regulatory Frameworks in Latin America? Country

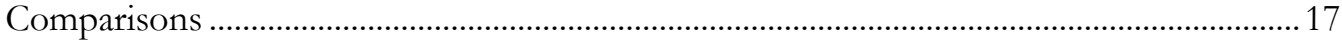

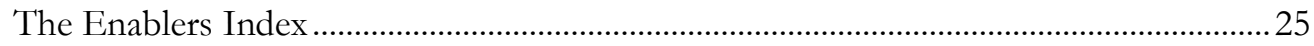

IV. Assessing Regulations classified as Promoters of Financial Inclusion......................26

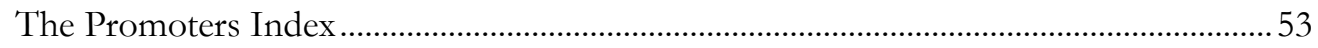

V. Assessing Regulations Constraining Financial Inclusion: The Preventers.....................55

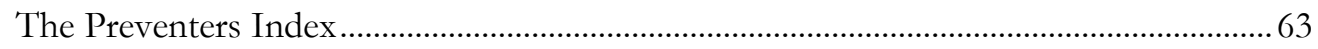

VI. The Overall Index of Regulations for Financial Inclusion ......................................... 64

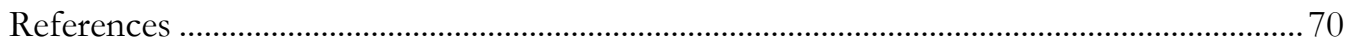

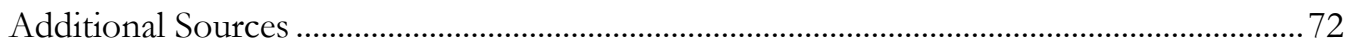

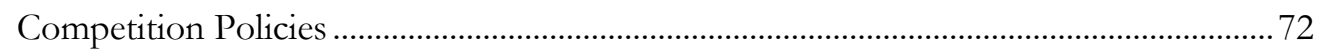

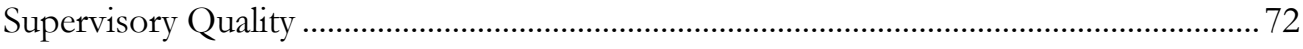

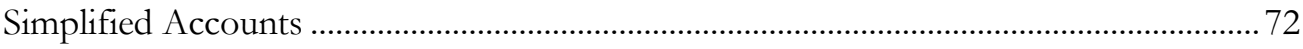

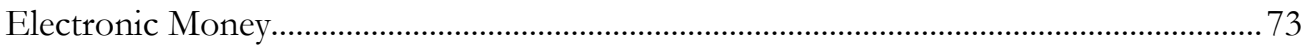

Banking Correspondents ................................................................................................ 74 


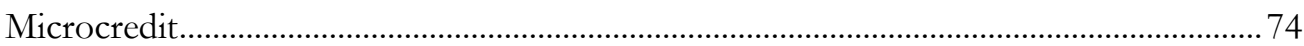

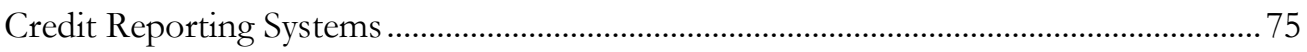

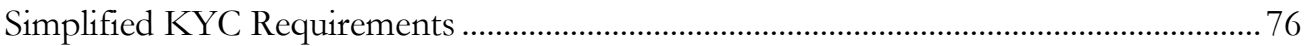

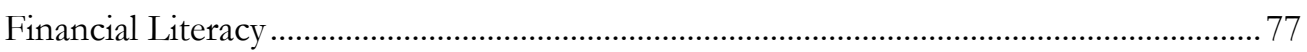

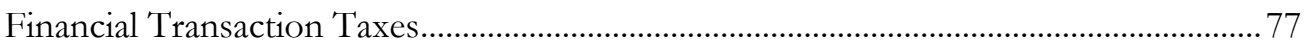

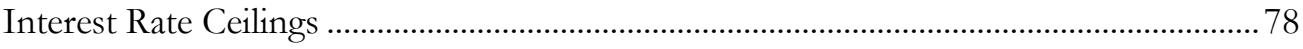

Directed Lending ...................................................................................................... 79

Annex I: Sub-Indices Indicators_-Definitions and Scoring Methodology ........................... 80

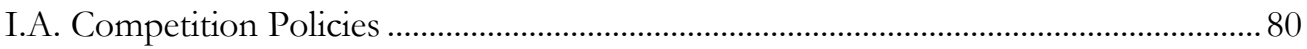

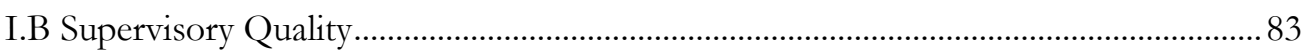

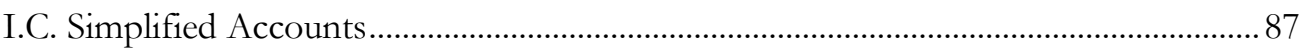

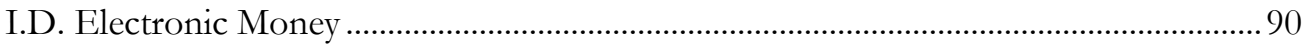

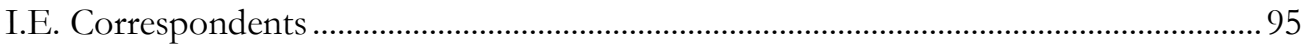

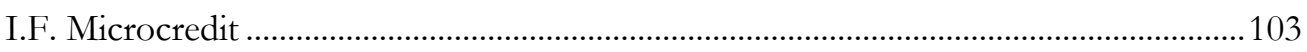

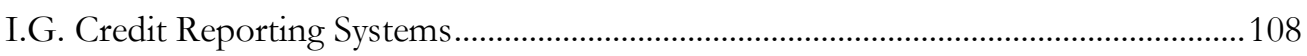

I.H. Simplified KYC Requirements ............................................................................. 112

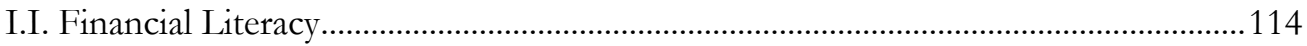

I.J. Financial Transaction Taxes .............................................................................117

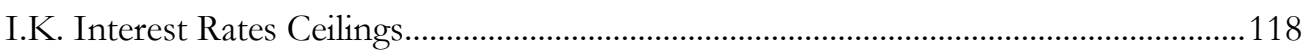

I.L. Directed Lending............................................................................................... 118

Annex II: Competition Policies: Summary of Regulatory Findings .......................................119

Annex III: Supervisory Quality: Methodological Considerations .........................................121

A. Original Questions and Scoring in Barth, Levine and Caprio (2005 and 2013).......121

B. Original and Updated Scores for the Indicators...........................................................124

Annex IV: Supervisory Quality: Summary of Regulatory Findings .....................................126 
Annex V: Regulatory Frameworks for Simplified Accounts...............................................128

Annex VI: Simplified Accounts: Summary of Regulatory Findings.....................................129

Annex VII: Regulatory Frameworks for Electronic Money..................................................131

Annex VIII: Electronic Money: Summary of Regulatory Findings ...................................132

Annex IX: Regulatory Frameworks for Correspondents.................................................135

Annex X: Correspondents: Summary of Regulatory Findings...............................................136

Annex XI: Microcredit: Summary of Regulatory Findings...................................................139

Annex XII: Credit Reporting Systems: Summary of Regulatory Findings .........................142

Annex XIII: Simplified KYC Requirements: Summary of Regulatory Findings...............144

Annex XIV: Financial Literacy: Summary of Regulatory Findings .....................................146

Annex XV: Financial Transaction Taxes: Summary of Regulatory Findings ......................148

Annex XVI: Financial Transaction Taxes in Brazil ................................................................149

1. Contribucao provisoria sobre movimentacao ou trasmissao de valores e de creditos e direitos de natureza financiera (CPMF) ........................................................................149

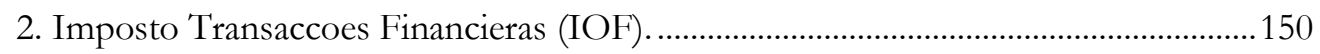

Annex XVII: Interest Rates Ceilings: Summary of Regulatory Findings .............................153

Annex XVIII: Directed Lending: Summary of Regulatory Findings...................................154

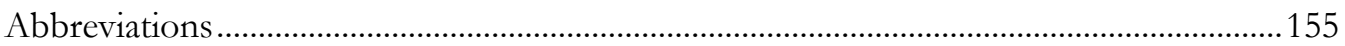




\section{Executive Summary}

This paper assesses and compares the quality of rules and regulations impinging on financial inclusion in a sample of eight Latin American countries: Argentina, Brazil, Chile, Colombia, Mexico, Paraguay, Peru, and Uruguay. By identifying weaknesses and strengths of specific regulatory practices in individual countries, the paper aims to support the efforts of policymakers in the region mandated with the task of improving financial inclusion.

The paper distinguishes itself from other empirical assessments of this kind in two important and complementary ways. ${ }^{1}$ First, by concentrating only in Latin America, the analysis focuses on issues and variables that are particularly relevant to the region. Second, the paper recognises that the effectiveness of a number of regulations for financial inclusion is influenced by the quality of other regulatory practices and by certain government interventions. That is, there is an interaction between regulations that affect their overall quality. In addition, relative to other work done in this area, this paper conducts a more specific and detailed assessment of the regulatory practices considered.

The 11 regulatory practices discussed in this paper are classified into three categories: those that determine the overall quality of the financial environment where providers of financial services operate (the enablers); those that deal with specific types of market frictions and describe the rules of the game for the provision of specific financial products and services (the promoters); and those that, albeit unintentionally, create distortions and barriers that adversely affect financial inclusion (the preventers). We construct an index for each of these three categories and sub-indices for the 11 regulatory practices/policies that form the indices (Table 1).

Table 1: Indices of Regulatory Quality and their components

\begin{tabular}{|c|c|c|c|c|c|}
\hline & Enablers & \multicolumn{2}{|r|}{ Promoters } & \multicolumn{2}{|r|}{ Preventers } \\
\hline 0 & $\begin{array}{l}\text { Competition } \\
\text { Policies } \\
\text { Supervisory } \\
\text { Quality }\end{array}$ & $\begin{array}{l}0 \\
0 \\
0 \\
0 \\
0 \\
0\end{array}$ & $\begin{array}{l}\text { Simplified Accounts } \\
\text { Electronic Money } \\
\text { Correspondents } \\
\text { Microcredit } \\
\text { Credit Reporting Systems } \\
\text { Simplified Know-Your- } \\
\text { Customer (KYC) } \\
\text { requirements }\end{array}$ & $\begin{array}{l}0 \\
0 \\
0\end{array}$ & $\begin{array}{l}\text { Transaction Taxes } \\
\text { Interest Rate Ceilings } \\
\text { Directed Lending }\end{array}$ \\
\hline
\end{tabular}

In addition, we also constructed a sub-index for assessing government efforts in promoting Financial Literacy. This sub-index is used as an adjustment factor in calculating the score of the Promoters index.

The assessment of individual regulatory practices is based on the construction of sub-indices, whose components include accepted standards as well as relevant interactions with other

${ }^{1}$ In particular, The Economist Intelligence Unit report: Global Microscope 
regulations and government interventions. Sub-indices receive scores in the 0-2 range and are then aggregated by categories to create the enablers, promoters, and preventers indices. A final, overall index incorporating all three categories is also constructed. The paper details the methodology utilized for the construction of the indices.

\section{How Enabling Are the Regulatory Frameworks in Latin America?}

A central feature of an enabling regulatory framework for financial inclusion is that it facilitates the adoption and adaptation of innovations that safely allow for an increased usage of financial services by large segments of the population, especially the poor. Thus, such enabling regulatory framework for financial inclusion needs to rest on two pillars. The first is the application of adequate competition policies that encourage a variety of providers to expand the range of customers receiving financial services. The second pillar is a complementary and robust supervisory regime to ensure progress in financial inclusion in a sustainable manner, and this regime requires supervisors to have adequate tools and sufficient autonomy to take action in the event that problems emerge in financial institutions. Thus, the Enablers index is composed of the Competition Policies sub-index and the Supervisory Quality sub-index.

The Competition Policies sub-index is made up of four indicators that define rules on (a) market entry, (b) market exit, (c) abuses of market power and (d) the contestability of inputs and interoperability. Results show that regulatory strengths and weaknesses vary significantly across countries. A common characteristic among the highest performers (Argentina, Chile, Colombia, Mexico and Paraguay with a score of either 1.8 or 1.7) is that all countries received the maximum score in the indicator abuses of market power. Beyond that, the regulatory differences are large. On the opposite side, Brazil receives the lowest overall score (1.3) among countries in the sample, closely followed by Uruguay (1.4).

The Supervisory Quality sub-index is formed by two indicators: the supervisory powers indicator and the independence of supervisors' indicator. On an overall basis, Peru and Paraguay stand out as the strongest countries in terms of the quality of the supervisory regime. By contrast, Argentina gets a very low overall score (0.7) and the last position in the sample. One important reason for this low score is that current legislation does not ensure the independence of the supervisor from political influence. In the rest of the countries, the scores also signal evidence of insufficient independence of the supervisor, albeit to a lesser extent than in Argentina. Regarding supervisory powers, Chile, Uruguay, Brazil and Mexico obtain relatively high scores.

Table 2 presents the Enablers index and its components. The value of the overall index is the simple average of the scores obtained for the two sub-indices. 
Table 2: The Enablers Index in Selected Latin American Countries. The Scores

\begin{tabular}{|l|c|c|c|c|c|c|c|c|}
\hline Criteria / Country & Argentina & \multicolumn{1}{c}{ Brazil } & \multicolumn{1}{c}{ Chile } & \multicolumn{1}{c}{ Colombia } & \multicolumn{1}{c}{ Mexico } & Paraguay & Peru & Uruguay \\
\hline Competition policies & 1.7 & 1.3 & 1.8 & 1.7 & 1.8 & 1.7 & 1.6 & 1.4 \\
Supervisory quality & 0.7 & 1.5 & 1.5 & 1.2 & 1.4 & 2 & 2 & 1.5 \\
Enablets Score & 1.2 & 1.4 & 1.7 & 1.5 & 1.6 & 1.9 & 1.8 & 1.5
\end{tabular}

Paraguay achieves the highest score in the Enablers index, while Chile, Peru and Mexico are not far behind. While the soundness of Competition Policies is the main source of strength in Chile and Mexico, a perfect score in Supervisory Quality supports the overall results in Peru. Brazil, Colombia and Uruguay achieve lukewarm results, while Argentina (with a score of only 1.2) occupies the last position among the countries in the sample. In this country, significant efforts are needed if the regulatory framework is going to enable progress in financial inclusion.

\section{Assessing Regulations Classified as Promoters of Financial Inclusion}

Promoters consist of regulatory frameworks that allow and encourage the usage of specific financial products and services designed to deal with market frictions that stand in the way of greater financial inclusion, such as (i) high transactions costs in the provision of financial services and (ii) informational asymmetries. There are three features that impinge on the construction of the Promoters index, stemming from the interrelationships between these frameworks and other regulations and policies. The first is that the power of a Promoter as a financial inclusion tool is affected by some characteristics of the overall regulatory environment (the enablers). For example, while it is desirable for the regulatory frameworks for Simplified Accounts and Electronic Money not to impose restrictions on fees and commissions charged by the suppliers of these products, this desirability holds only as long as adequate Competition Policies drive a healthy degree of competition between providers in the system. A second feature affecting the construction of the scoring system is that the effectiveness of a number of Promoters can be enhanced by additional government efforts. For example, by fostering the payment of salaries, pensions or transfer for social programmes through deposits in Simplified Accounts or Electronic Money accounts, the usage of these products is encouraged. In spite of these efforts, however, there is evidence that the usage by the poor of payments and savings products offered by the formal financial system is limited to the periodic withdrawal of the money received. In addition to issues of trust in the formal financial systemespecially in countries with a history of high levels of inflation-lack of financial literacy has often been identified as an important reason behind this occurrence. This brings us to the 
third feature affecting the scoring system: financial literacy affects the outcomes of all regulatory Promoters, and, therefore, the scoring of the overall Promoters index. ${ }^{2}$

The first promoter, Simplified accounts, refers to accounts with limits on balances and transactions and that are subject to streamlined KYC requirements, which can serve the dual purpose of protecting financial integrity and encouraging financial inclusion. Assessments of Simplified Accounts show large divergence between countries. Indicators defining minimum regulatory standards governing the provision of these accounts, show that no country receives a perfect score, but Mexico, Colombia, Peru and Uruguay (with a score of 1.6 or 1.5) perform best. On the opposite side, Brazil, Chile, Argentina and Paraguay attain the lowest scores in meeting minimum regulatory standards, while in Chile there is no dedicated regulatory framework for Simplified Accounts. In terms of additional government efforts to encourage the usage of Simplified Accounts, all countries but Uruguay have attempted to support these accounts through existing conditional cash transfer programmes. When all factors are considered, the Simplified accounts sub-index shows the strength of Colombia (with a score of 1.7) among the countries in the sample, while Brazil obtains the lowest score.

As more countries in the region are issuing regulations for the offering of Electronic Money, it is crucial to ensure that the regulatory framework for the provision of this service meets high standards. Thus, indicators defining minimum regulatory standards identify whether there is a dedicated regulatory framework for electronic money and assess whether rules and regulations for providers and their network of agents guarantee a level playing field among the different suppliers and safeguard the stability of the financial system and effectively protect customers.

Regulation on electronic money is quite new in the region and some countries have either not issued regulations (Argentina and Mexico) or the regulations are still incomplete (Chile). Among the rest of countries in the sample, Peru, Brazil and Colombia distinguish themselves for the high quality of their regulatory standards for electronic money, while in Paraguay and Uruguay there is room for improvement on this front. For instance, both countries lack sufficient provisions to safeguard customers' funds and there are important restrictions on the fees and commissions to be charged. Still, there are significant differences in countries' efforts to promote the use of electronic money that explain differences in the final scores for the electronic money sub-index.

The third promoter assesses the quality of the regulatory framework for Correspondents. The Correspondents sub-index is made up of nine indicators defining regulations that answer four sets of questions: (a) who qualify as correspondents and what can correspondents do?, (b) who is accountable for the activities of correspondents and how can this accountability be enforced?, (c) how do they deal with the issue of exclusivity, namely the right of a

\footnotetext{
${ }^{2}$ However, to maintain the focus on regulations classified as Promoters, we kept the adjustment factor for financial literacy at low levels.
} 
correspondent to be associated with only one financial institution?, and (d) is there any role for the regulation of fees and commissions associated with the operation of correspondents?

With a score of 1.97, Colombia almost gets the highest possible score as there are no significant regulatory impediments to the adequate operation of correspondents. ${ }^{3}$ Paraguay and Peru also get very high scores (1.8 and 1.9), with Mexico and Uruguay not far behind (1.7 and 1.6). Lower scores have been obtained by Brazil and Chile, although the areas where improvements are called for differ among these two countries. Finally, there is no regulatory framework for agents in place in Argentina and thus, this country obtains the lowest possible score.

Laws and regulations guiding the offering of microcredit products by banks and non-banks constitute the fourth element of the Promoters index. The Microcredit sub-index is made up of four indicators that reflect the distinctive features and inherent risks of this financial service: an indicator that deals with overarching characteristics of the regulatory framework and three focusing on legal rules to govern and oversee the provision of microcredit (prudential and nonprudential regulation and the framework for microcredit supervision).

Peru and Colombia (with overall scores of 1.9 and 1.6 respectively) attain the best positions among countries in the sample, although Colombia has room for improvement as regards prudential regulation. Other countries achieve more intermediate scores, with room for improvement in the regulatory framework (Mexico), non-prudential regulation (Argentina), microcredit supervision (Brazil) and prudential regulation (Chile). Finally, the lowest scores are obtained in Paraguay and Uruguay. Uruguay (together with Chile) stands out as the country in the sample that does not incorporate a definition of microcredit in the regulation; as a consequence, this country also lacks a regulatory framework for risk management of microcredit portfolios. Among the countries in the sample, Paraguay receives the lowest score in non-prudential regulation.

Credit reporting systems, formed by credit bureaus and credit registries, address the problem of the asymmetry of information in credit markets. Critically important, availability of comprehensive information on borrowers provides those at the base-of-the-pyramid with "reputational collateral", a potentially highly valuable asset arising from a positive credit history. ${ }^{4}$ The Credit Reporting Systems sub-index measures those rules that define the coverage, quality, accessibility and safety of credit information available either through a credit bureau, a credit registry, or both, through indicators on the comprehensiveness of information and the accessibility and safety of the information gathered.

Among all the sub-indices discussed in this paper, Credit Reporting Systems is notable for the high scores in most of the countries. For example, Argentina, Colombia, Mexico, Peru and Uruguay obtain the maximum score. In Brazil, the most important shortcoming identified is

\footnotetext{
3: Lack of explicit regulatory authorisation for certain transactions with no risk of fraud to be conducted off-line prevents Colombia from achieving an overall score of 2.

4: See CGAP (2011b)
} 
that there are deficiencies in certain legislation that prevents private credit bureaus from collecting positive information about borrowers. In Paraguay, private credit bureaus are only allowed to gather negative information and there are deficiencies in terms of the scope of information and lack of clarity in the legislation on how individuals can correct erroneous information. Finally, Chile is the country in the sample with the lowest score and this is largely the result of deficiencies in legislation regarding the comprehensiveness of information gathered.

The Simplified KYC Requirements sub-index assesses the extent to which the principle of proportionality is incorporated in countries' KYC rules and whether these rules are similarly applicable to alternative providers of financial services. It is made up of four indicators: an indicator that deals with the issue of creating a level playing field among providers, and three that deal with the adequate usage of simplified customer due diligence (CDD) procedures (identification, verification and record-keeping) for low-income customers. ${ }^{5}$

Results for this sub-index show that the countries in our sample can be divided into two groups: those with the highest possible (Argentina, Peru and Uruguay) or a very high (Brazil and Mexico) score, and those with low scores (Chile, Colombia and Paraguay). In Colombia, the regulation is not clear about how financial institutions can verify the identity of customers, while in Chile the regulation does not clearly define either the documents needed for a reliable verification of customers' identity or the record-keeping requirements. Finally, in Paraguay simplified CDD procedures do not apply to cooperatives, which, as reported by the World Bank (2014) could facilitate the opening of accounts in rural areas. In addition, when applicable, simplified identity requirements for KYC are too restrictive since they include proof of income.

Finally, as already mentioned, policies to enhance financial literacy impact the outcome of all regulatory Promoters. Thus, we have constructed a sub-index assessing the quality of government efforts to improve Financial Literacy, which is then used to adjust the scores in the Promoters index. The Financial Literacy sub-index is formed by two indicators: one on the institutional framework for financial education and another one assessing policy efforts in place. Among the countries in the sample, Brazil and Peru achieve the maximum score, as are the only two countries where there is a coordinated policy response for promoting financial education. On the other side, the low performers (Uruguay, Argentina and Paraguay) share a number of weaknesses, but the absence of mechanisms for cooperation among relevant public authorities and between the public and private sector stands out.

\footnotetext{
5: Due to insufficient guidance from standard-setting bodies, the Simplified KYC Requirements sub-index does not assess the quality of the enforcement framework for KYC rules. This is, unfortunately, an important shortcoming for the construction of and interpretation of results from the sub-index of Simplified KYC Requirements.
} 
Table 3 shows the Promoters Index and its components. ${ }^{6}$ With an adjusted score of 1.9, Peru achieved the highest score in the sample, while Colombia is relatively close behind, with an adjusted score of 1.75 . In the rest of the countries, the adjusted scores reflect significant room for improvement. In Brazil, most of the Promoters sub-indices achieve low values, with the exception of Simplified KYC and, to a certain extent, Credit Reporting Systems. In Mexico, top or very high scores in Credit Reporting Systems and Simplified KYC cannot offset the underperformance in some areas such as E-money. Mixed performance of Promoters is also a feature of Paraguay and Uruguay. In contrast, Chile did not achieve high scores in any of the Promoters. Financial Literacy policies also need to be upgraded in Chile, Mexico, Paraguay and Uruguay. Finally, Argentina gets the lowest adjusted score among the countries in the sample. In this case, there is a mix of Promoters with top scores and extremely weak ones. Efforts on Financial Literacy have a long way to go.

Table 3: The Unadjusted and Adjusted Promoters Index in Selected Latin American Countries. The Scores

\begin{tabular}{|c|c|c|c|c|c|c|c|c|}
\hline Criteria / Country & Argentina & Brazil & Chile & Colombia & Mexico & Paraguay & Peru & Uruguay \\
\hline Simplified accounts & 1.5 & 0.8 & 1.4 & 1.7 & 1 & 0.9 & 1.1 & 0.9 \\
\hline E-money & 0 & 1.2 & 0.8 & 1.9 & 0 & 1.7 & 1.6 & 1.6 \\
\hline Correspondents & 0 & 1.3 & 1.3 & 2 & 1.7 & 1.8 & 1.9 & 1.6 \\
\hline Microcredit & 1.1 & 1.2 & 1.1 & 1.6 & 1.3 & 1 & 1.9 & 1 \\
\hline $\begin{array}{l}\text { Credit Reporting } \\
\text { Systems }\end{array}$ & 2 & 1.6 & 1.3 & 2 & 2 & 1.4 & 2 & 2 \\
\hline Simplified $K Y C$ & 2 & 1.8 & 1 & 1 & 1.9 & 1.3 & 2 & 2 \\
\hline $\begin{array}{l}\text { Unadjusted Promoters } \\
\text { Score }\end{array}$ & 1.1 & 1.3 & 1.2 & 1.7 & 1.3 & 1.4 & 1.8 & 1.5 \\
\hline Financial Literacy & 0.9 & 2 & 1.3 & 1.5 & 1.5 & 0.9 & 2 & 0.8 \\
\hline $\begin{array}{l}\text { Adjusted Promoters } \\
\text { Score (for Financial } \\
\text { Literacy) }\end{array}$ & 1.1 & 1.4 & 1.25 & 1.75 & 1.35 & 1.4 & 1.9 & 1.5 \\
\hline
\end{tabular}

\section{Assessing Regulations Constraining Financial Inclusion: The Preventers}

Despite their good intentions, some regulations can result in significant distortions that hinder the use of financial services and promote severe inefficiencies. These financial inclusion preventers take many forms and vary across countries. However, the most widely

\footnotetext{
6: The value of the unadjusted index is the simple average of the scores obtained for the six sub-indices. However, as discussed above, Financial Literacy affects the outcomes of all regulatory promoters; this is reflected in the Adjusted Promoters Index.
} 
used regulations in this category are (a) taxes on financial transactions; (b) interest rate ceilings; and (c) directed lending.

Financial transaction taxes (FTT), that is, taxes applied to bank liabilities-typically fund withdrawals from checking and savings accounts 7 - encourage financial disintermediation by increasing the cost of making transactions through banks. However, not all transaction taxes are designed equally in those Latin American countries that rely on them. Some are more pervasive than others as regards financial inclusion: some taxes are also applied to credit operations, while others incorporate features that reduce their adverse effect. Among the countries in the sample, Uruguay and Paraguay stand out for achieving the highest possible score since these taxes are not used at all in their financial systems. At the opposite end, Brazil and Chile obtain a score of zero. In both cases the tax is levied on credit transactions and neither country has legislation in place that could mitigate the effect of the taxes on financial inclusion. Argentina, Colombia, Mexico and Peru have bank debit taxes in place. ${ }^{8}$ However, there are significant differences in regulations affecting the impact of the taxes on financial inclusion in these countries in terms of exemptions in the payment of the tax, the tax rate or whether the amount paid for the tax can be fully deducted against payment of other taxes.

Interest rate ceilings, often known as usury laws, stipulate maximum interest rates for loans to prevent credit providers from imposing excessive rates on debtors. Despite of its good intentions, it has been shown that this regulation has hindered access to credit by certain small and middle size enterprises (SMEs). In constructing the sub-index on Interest Rates Ceilings, we have used a single indicator that assesses whether: (a) caps are in place and (b) the extent to which existing caps are effectively distorting the provision of credit at the present time, especially to low income or excluded groups. Two countries in the sample, Mexico and Peru, do not use interest rate ceilings and, therefore, obtained the maximum score. By contrast, in Brazil, Colombia, Chile and Uruguay interest rate caps are in place and are reportedly assessed as creating important distortions in the provision of credit to small enterprises and low-income customers. Finally, in Argentina and Paraguay ceilings are set for interest rates on credit cards, but do not create distortions for the population at the base of the pyramid.

Finally, government interventions in credit markets through development banks can play an important role for financial inclusion in the presence of market failures, but only if their actions do not create additional market distortions. Thus, the sub-index of Directed Lending is based on an indicator whose value decreases as the market distortions created by government intervention increase. Chile, Mexico and Peru are the best performers in this category and obtain the maximum score. The other countries in the sample obtain a score of zero, because Governments in those countries significantly influence the allocation of credit

\footnotetext{
7: These bank debit taxes are the most common, although other countries also tax credit, securities or currency transactions.

8: In Argentina and Peru, the tax is also levied on credit transactions.
} 
through both directed lending programmes and direct lending from state-owned banks that create generalized distortions in credit markets.

Table 4 presents the Preventers index and its components. The value of the overall index is the simple average of the scores obtained for the three sub-indices.

Table 4: The Preventers Index in Selected Latin American Countries. The Scores

\begin{tabular}{|l|c|c|c|c|c|c|c|c|}
\hline Criteria / Country & Argentina & Brazil & \multicolumn{2}{c}{ Chile } & \multicolumn{2}{c|}{ Colombia } & Mexico & \multicolumn{2}{c|}{ Paraguay } & \multicolumn{2}{c}{ Peru } & Uruguay \\
\hline $\begin{array}{l}\text { Adjusted Financial } \\
\text { Transaction Taxes }\end{array}$ & 0.5 & 0 & 0 & 0.5 & 1 & 2 & 1 & 2 \\
Interest rate ceilings & 1 & 0 & 0 & 0 & 2 & 1 & 2 & 0 \\
Directed lending & 0 & 0 & 2 & 0 & 2 & 0 & 2 & 0 \\
Preventers Score & 0.5 & 0 & 0.7 & 0.2 & 1.7 & 1 & 1.7 & 0.7
\end{tabular}

The highest score for this index was obtained by Mexico and Peru (with a score of 1.7) largely because both countries received maximum scores in the sub-indices for Interest Rates Ceilings and Directed Lending. At the opposite end is Brazil with the lowest possible score in the three components in the index, closely followed by Colombia and Argentina. Chile and Uruguay also received very low scores, followed by Paraguay.

\section{The Overall Index of Regulations for Financial Inclusion}

The three estimated indices, the Enablers, the Promoters (adjusted) and the Preventers, can be combined to obtain an Overall Index of Regulations for Financial Inclusion (Table 5). As derived from the table, there is a large difference between countries regarding areas of strengths and weaknesses.

Table 5: The Overall Index of Regulations for Financial Inclusion in Selected Latin American Countries. The Scores

\begin{tabular}{|l|c|c|c|c|c|c|c|c|}
\hline Criteria / Country & Argentina & \multicolumn{1}{c}{ Brazil } & \multicolumn{1}{|c|}{ Chile } & \multicolumn{1}{c|}{ Colombia } & \multicolumn{1}{c|}{ Mexico } & Paraguay & Peru & Uruguay \\
\hline Enablers Index & 1.2 & 1.4 & 1.7 & 1.5 & 1.6 & 1.9 & 1.8 & 1.5 \\
Adjusted Promoters & 1.1 & 1.4 & 1.25 & 1.75 & 1.35 & 1.4 & 1.9 & 1.5 \\
Index & 0.5 & 0 & 0.7 & 0.2 & 1.7 & 1 & 1.7 & 0.7 \\
Preventers Index & 0.9 & 0.9 & 1.2 & 1.2 & 1.6 & 1.4 & 1.8 & 1.2 \\
\hline Overall Index Score & 0.9
\end{tabular}

Peru ranks first, followed closely by Mexico. Both countries scored well in the Enablers index, but while Peru received a very high score in the Adjusted Promoters index and a low score in the Preventers, Mexico obtained opposite results. With a score of 1.4, Paraguay takes third place. The country stands out due to the soundness of its Enabling regulations, but displayed important shortcomings in the other two indices. Chile, Colombia, and Uruguay 
share a common low score of 1.2. Just as with Paraguay, for Chile a high score in the Enablers index cannot offset low scores in the other two indices. In Colombia, the extremely low score of the Preventers index brings the value of the Overall Index down. Uruguay does not achieve high scores in any of the three indices, a feature shared with Argentina and Brazil, the two countries with the lowest overall scores. In these countries, major changes are needed if their regulatory frameworks are to reach their potential for improving financial inclusion.

A word of caution is important here. While central for financial inclusion, regulation is not the only factor influencing the demand for and the provision of financial services. Many constraints, such as institutional weaknesses, poverty, income inequality and macroeconomic imbalances can prevent improvements in financial inclusion. These obstacles can explain some stylized facts. For example, while Peru and Mexico obtain the top positions in the ranking regarding the quality of regulatory practices, they display very low levels of financial inclusion (World Bank Global Findex 2014). As identified in Rojas-Suarez (2016) institutional weaknesses might be the most important constraint for financial inclusion in these two countries.

As stated at the outset, the calculation of the scores has used a methodology that acknowledges both the peculiarities of Latin America and the interactions between the assessed regulations and those between regulatory practices and other types of government interventions in support of financial inclusion. It is our hope that these results serve to guide regulatory reforms. There is surely no unique way to define and aggregate the indicators, and different country rankings could be achieved if alternative scoring definitions or weights were defined; we, therefore, invite interested researchers to explore alternative methodologies that could guide future updates of this exercise. In this regard, beyond specific scores, perhaps the most important contribution of this paper lies in identifying with some detail the areas of strengths and weaknesses in financial regulatory practices for improving financial inclusion. 


\section{Introduction}

This paper assesses and compares the quality of rules and regulations impinging on financial inclusion in a sample of eight Latin American countries: Argentina, Brazil, Chile, Colombia, Mexico, Paraguay, Peru and Uruguay. By identifying weaknesses and strengths of specific regulatory practices in individual countries, the paper aims to support the efforts of policymakers in the region mandated with the task of improving financial inclusion.

The paper distinguishes itself from other empirical assessments of this kind in two important and complementary ways. ${ }^{9}$ First, by concentrating only in Latin America, the analysis focuses on issues and variables that are particularly relevant to the region. For example, given the importance of foreign banks in Latin America, the assessment of competition policies pays attention to the existence of regulatory practices than might create an unlevelled playing field between domestic (private and public) and foreign financial institutions. Moreover, given that a number of countries have started to issue regulations for the provision of e-money, this paper explores whether these new regulations contribute to the benefits of digital financial inclusion, while ensuring financial stability and integrity and consumer protection.

Second, the paper recognises that the effectiveness of a number of regulations for financial inclusion is influenced by the quality of other regulatory practices and by certain government interventions. That is, there is an interaction between regulations that affect their overall quality. Two examples can serve to clarify this point: first, a desirable characteristic for regulatory frameworks covering the offering of simplified bank accounts, with requirements tailored to the poor, is the absence of restrictions on fees and commissions to open and manage these accounts (since these restrictions could limit providers' ability to design commercially viable products). However, the desirability of this characteristic is not independent of the quality of competition policies. That is, leaving fees and commissions unrestricted is contingent on the prevention of deep-rooted monopoly powers through strong competition policies. A second example is the interaction between regulations that create incentives for the usage of a number of financial services aimed at the poor (such as microcredit, simplified accounts, and e-money) and regulatory policies for financial education. Specifically, the evidence suggests that the lack of financial literacy can be an important factor preventing the effective usage of these services. Thus, this paper's assessment of the quality of regulations for a set of specific financial products/services incorporates an assessment of the adequacy of regulatory policies on financial literacy.

The regulations discussed in this paper are by no means exhaustive of the potential regulatory changes that can be considered by policymakers to improve financial inclusion. Nevertheless, the sample discussed here is sufficiently diverse to cover the provision of payments and transfers services, savings and credit. ${ }^{10}$ We analyse 11 regulatory practices classified into three categories: those that determine the overall quality of the financial environment where providers of financial services operate (the enablers); those that deal with

9: Such as, for example, The Economist Intelligence Unit (2016) and Brookings (2017)

10: Regulations promoting the provision of insurance products are not discussed in the paper. 
specific types of market frictions and describe the rules of the game for the provision of specific financial products and services (the promoters); and those that, often unintentionally, create distortions and barriers that adversely affect financial inclusion (the preventers).

The assessment of individual regulatory practices is based on the construction of sub-indices, whose components include accepted standards as well as relevant interactions with other regulations and government interventions. Sub-indices are then aggregated by categories to create the enablers, promoters and preventers indices. A final, overall index incorporating all three categories is also constructed.

The rest of this paper is organised as follows: Section II defines the scope of the study by identifying the regulatory practices to be considered in the assessments. This section also explains the methodology used to construct the indices of regulatory quality for financial inclusion. Sections III through V deal separately with each of the three categories of regulatory practices considered (enablers, promoters and preventers). In each section, sub-indices for the individual regulations making up the relevant index are constructed. The components of each sub-index and its scoring system are defined. The scoring system is then applied to the countries in the sample to gauge the quality of the regulations considered. Section VI presents and discusses the results from an overall, aggregated index of regulatory practices for financial inclusion.

\section{Assessing Regulations: Scope of the Study and Methodology}

The scope of this study is defined by those regulations and policies impacting on the offering of financial services to low-income populations and their usage. This section groups these regulatory practices into categories and explains the methodology to be used in the rest of the paper to construct indices of regulatory quality.

\section{Three Dimensions of Regulatory Practices Affecting Financial Inclusion:}

Broadly speaking, regulatory practices and policies affecting financial inclusion can be classified into three categories: (a) those that characterise the overall financial environment in which providers of financial services that serve the needs of the poor operate (the enablers);

(b) those that aim to deal with specific market frictions and, therefore, facilitate and promote the provision of specific financial services to large segments of the population (the promoters); and (c) those that, often unintentionally, generate obstacles for expanding the supply of and demand for financial products and services (the preventers).

\section{a. Enablers}

A central feature of an enabling regulatory framework for financial inclusion is that it facilitates the adoption and adaptation of innovations that safely allow for an increased usage of financial services by large segments of the population, especially the poor. As documented in the literature, recent developments in technology imply that, to a large extent, advances in 
financial inclusion could be achieved through digital finance involving payments, savings, credit, and insurance products. While the opportunities that these new technologies can bring are certainly being recognised, so are the potential risks to the consumer and the overall financial system associated with the entrance of new players and new business models for the provision of financial services. Thus, an enabling regulatory framework for financial inclusion needs to rest on two pillars. The first is the application of adequate competition policies that encourage a variety of providers to expand the range of customers receiving financial services and the range of products that meet the needs of low-income populations. The second is a complementary and robust supervisory regime to ensure that progress in financial inclusion is consistent with the maintenance of stability and integrity of the overall financial system and the protection of consumers. As will be discussed below, this regime requires supervisors to have adequate tools and sufficient autonomy to take action in the event that problems emerge in financial institutions.

\section{b. Promoters}

Regulatory interventions classified as promoters deal with specific market frictions that stand in the way of greater financial inclusion, such as (i) high transactions costs in the provision of financial services and (ii) informational asymmetries. ${ }^{11}$

High transaction costs can result from multiple factors, including geographical conditions (whereby remote and low-density populations, especially in rural areas, are costly to serve), and fixed costs (arising from the use of financial infrastructure, legal and accounting services, due diligence requirements for either opening bank accounts or extending credit—including for meeting know your customer requirements — and monitoring of accounts). In the presence of fixed costs, financial intermediaries have to exploit economies of scale to become profitable and sustainable. As noted in Beck and de la Torre (2010), these economies of scale can be achieved through either high-volume or high value, but not necessarily through both. It is, therefore, not surprising that in a number of countries, where geographical constraints combine with high fixed costs, financial institutions achieve profitability by serving a limited number of "high-value" customers.

Regulations grouped as promoters can lower transactions costs by streamlining rules and requirements imposed on providers of financial services that serve the poor (to the extent that new risks to the soundness and integrity of the financial system are not created) or by allowing the use of new technologies that reduce the geographical barrier. Examples of these regulations include (a) permitting financial institutions to offer simplified accounts; (b) permitting banks and other financial institutions to establish a network of non-bank agents (correspondents) to deliver their services; (c) allowing banks and other qualified digital service providers to engage in payments and transfer services through the usage of electronic

\footnotetext{
11: High costs in the provision of financial services can also be the result of oligopolistic powers. However, in this paper regulations dealing with competition problems are classified under the "enablers" category.
} 
money $^{12}$; and (d) implementing less stringent know your customer (KYC) requirements for low-income, low-risk customers.

Constraints on financial inclusion arising from informational asymmetries are largely manifested in credit markets. Getting information about low income customers (households and firms) and their projects could involve punitive costs for lenders and thus, profitable investments could go unfunded. Moreover, lack of titling of land and other assets held by the poor prevent the usage of these assets as collateral to obtain loans. Examples of regulatory interventions that deal with these problems are: (a) implementation of new financial sector laws and regulations (or modification of old ones) guiding the offering of microcredit products by banks and non-banks financial institutions, while preventing customers' over-indebtedness; and (b) establishment of regulatory incentives to financial institutions for sharing borrowers' credit information (through a credit reporting system), including positive and negative information on the borrower's payment history. In the absence of physical collateral, poor borrowers' can build reputational collateral.

\section{c. Preventers}

Despite their good intentions, some regulations can result in significant distortions that hinder the use of financial services and promote severe inefficiencies. These financial inclusion preventers take many forms and vary across countries. However, the most widely used regulations in this category are (a) taxes on financial transactions; (b) interest rate ceilings; and (c) directed lending. Financial transaction taxes (FTT), that is, taxes applied to bank liabilities, typically fund withdrawals from chequing and savings accounts, ${ }^{13}$ are imposed for strictly fiscal purposes. While their intention is merely to collect government revenues, these taxes encourage financial disintermediation since depositors (individuals and firms) try to avoid paying the tax by making fewer transactions through banks and increasing the number of cash transactions. By increasing the cost of making transactions through banks (and other financial institutions whose liabilities are subject to the tax), the FT'T runs counter to the efforts of increasing people's usage of formal financial services. Moreover, the FTT weighs more heavily on smaller firms with fewer resources; the reason being that larger companies have a greater ability to avoid the tax through access to off-shore transactions and operations with derivatives.

Interest rate ceilings, often known as usury laws, stipulate maximum interest rates for loans to prevent credit providers from imposing excessive rates on debtors. Despite the good intentions of this regulation, it has been shown that its effects have been counterproductive in cases where the cap is set below the level the market would settle at. The regulation has hindered access to credit by certain small and middle size enterprises (SMEs) since, due to their risk characteristics, banks are only willing to lend to them at interest rates higher than

\footnotetext{
12 As clarified in section IV, electronic money is broadly defined as a "record of funds or value available to consumers stores on a payment device, such as a chip, a prepaid card, or a mobile phone, or on a computer system as a non-traditional account with a banking or non-banking entity" (World Bank, 2012)

13: These bank debit taxes are the most common, although other countries also tax credit, securities or currency transactions.
} 
the maximum ones allowed by law. What about consumers? Also chokes of lending to consumers.

In a similar vein, direct lending from state-owned banks and regulations ordering banks to allocate a certain share of their loan portfolio to economic sectors selected by the government (directed lending) can potentially hurt financial inclusion unless properly designed and mandated only on a temporary basis (to support the emergence of markets). The problem with these types of regulations is that they tend to reduce financial institutions' incentives to assess the quality of borrowers. As a result, resources might not be allocated to the most productive investments and might induce an increase in the ratio of nonperforming loans and financial stability concerns. Thus, not only would those SMEs and microenterprises excluded from the favoured sectors find themselves credit-constrained by the formal financial system, but also those SMEs and microenterprises working in the favoured sectors might find that their access to funding is not sustainable.

\section{Constructing Indices of Regulatory Quality: The Methodology}

We have constructed an index of regulatory quality for each of the three dimensions of regulations for financial inclusion discussed above. Each index is made up of several subindices. Specifically:

Table 1: Indices of Regulatory Quality and their components

\begin{tabular}{|c|c|c|}
\hline Enablers & Promoters & Preventers \\
\hline $\begin{array}{l}\text { o Competition } \\
\text { Policies } \\
\text { o Supervisory Quality }\end{array}$ & $\begin{array}{l}\text { o Simplified Accounts } \\
\text { o Electronic Money } \\
\text { o Correspondents } \\
\text { o Microcredit } \\
\text { o Credit Reporting Systems } \\
\text { o Simplified Know-Your- } \\
\text { Customer (KYC) } \\
\text { requirements }\end{array}$ & $\begin{array}{l}\text { o Transaction Taxes } \\
\text { o Interest Rate Ceilings } \\
\text { o Directed Lending }\end{array}$ \\
\hline
\end{tabular}

In addition, we have also constructed a sub-index of Financial Literacy which, as explained in Section IV, will be used as an adjustment factor to the score of the Promoters' sub-index.

Constructing each sub-index involves a number of indicators of regulatory quality. A scoring ranging from 0 to 2 is created for each indicator, where 0 denotes the lowest possible degree of quality of the indicator and 2 the highest. In the majority of cases, the scores are set up to take the value of 0,1 and $2 .{ }^{14}$ Although the selection of indicators comprising the subindices and the setting of the scoring system for each regulatory practice involve a significant

\footnotetext{
14: In some cases, however, there is no need for an intermediate score and, therefore, there are only two possible values attached to the indicator: 0 and 2 . Yet, in other cases, nuances in the regulation require additional gradations in the scoring; in those cases, we have added 0.5 increments ( 0.5 and/or 1.5 , specifically)
} 
amount of discretion, we have based our criteria on the existing literature and on the increasing number of best practice guides from multilateral organisations and other sources.

There are two distinctive novelties in the construction of the sub-indices. The first is that in order to assess the quality of a regulation (the value of a sub-index) we have considered the interaction of some desirable characteristics of the regulation with other regulatory practices. For example, to construct the sub-indices for the quality of Simplified Accounts and Electronic Money, we have incorporated the effect of competition policies. Specifically, we have established that a desirable feature of regulatory frameworks for Simplified Accounts and Electronic Money is the absence of restrictions on fees and commissions for opening, maintaining and undertaking transactions using those products, as long as there are adequate competition rules in the financial sector. In other words, the desirability of leaving fees and commissions unrestricted is contingent on the prevention of entrenched monopoly powers through strong competition policies.

The second novelty regards the interaction of a regulation with other government interventions that enhance the financial inclusion potential of the regulation. Continuing with the examples of Simplified Accounts and Electronic Money, the regulatory quality for the offering of these products is assessed more positively if the government promotes the usage of the accounts by individuals and small firms through additional efforts rather than if it remains on the sidelines. Moreover, a government programme that promotes the usage of the accounts by individuals and firms in the informal sector (in addition to the formal sector) will be assessed as enhancing regulatory quality even further.

The effect of financial literacy policies on the effectiveness of regulatory policies classified as Promoters is another example of the interaction between regulations and other government interventions. Thus, the value of our Promoters index is assessed more positively if the authorities actively engage in the design and implementation of high-quality financial literacy policies than if efforts by the authorities are either absent or deficient.

Because of differences in the types of the indicators considered in each sub-index, the weighting system also varies across sub-indices. For example, in some sub-indices, such as the ones on Supervisory Quality and Simplified KYC Requirements, all the indicators are weighted equally; therefore, the value of the sub-index is simply the average of the scores attached to the indicators. In contrast, in other sub-indices, such as the aforementioned regulatory frameworks for Simplified Accounts and Electronic Money, there are three types of variables: (a) the characteristics of these products as established in the regulation, (b) the interaction of some characteristics with the adequacy of competition policies and (c) the degree of the government's efforts to enhance the financial inclusion power of the products. In these cases, the scoring and weighting systems are slightly more complex, as will be discussed in section IV.

The value of each of the three Indices of Regulatory Quality is simply the average of the value of the relevant sub-indices. 
The aggregation of the indicators to form the sub-indices and indices is subjective in nature. It is important to make clear, however, that there is surely no unique way to aggregate the indicators, and different country rankings could be achieved if alternative scoring definitions or weights were defined. In fact, further reflection on our part or alternative research from others could lead to modifications in the methodology in future updates to this exercise.

The significant challenges associated with the aggregation of information to construct indices are widely recognized in the literature. The detailed information on individual countries is of great interest on its own right, and perhaps, the most important contribution of this paper is the identification of particular areas of strengths and weaknesses in countries' regulatory practices. Nonetheless, the construction of indices facilitates the comparison across countries and time. Thus, while being fully aware of the existing challenges we have formulated the set of 11 sub-indices and 3 indices as an attempt to better guide the efforts of interested policy makers, while inviting researchers to explore alternative methodologies for the aggregation.

In the following sections, each index is considered in turn. After explaining the construction of the index, the methodology is applied to assess the regulatory quality for financial inclusion in the eight Latin American countries in the sample.

\section{How Enabling Are the Regulatory Frameworks in Latin America? Country Comparisons}

Here we consider the two types of regulatory policies classified as enablers: competition policies and the adequacy of the supervisory regime. In what follows, the indicators forming each of the two Enablers sub-indices are identified, the scoring methods are defined and scores are attached to the selected Latin American countries.

\section{a. Enabler 1: The Quality of Competition Policies}

Adequate competition policies encourage participation by a variety of providers of financial services while ensuring the stability and integrity of the financial system and the protection of consumers. The Competition Policies sub-index is made up of four indicators that define rules on (a) market entry, (b) market exit, (c) abuses of market power and (d) the contestability of inputs and interoperability. This classification is based on a report chaired by Claessens and Rojas-Suarez (2016).

The indicator on market entry seeks to evaluate whether all qualified providers, both traditional and alternative (such as non-bank digital service providers (DSPs)), are allowed to participate in the supply of financial services that benefit large segments of the population. The idea is that entry regulations should be commensurate with the risks of the activities undertaken by providers and that these regulations should create a level playing field between providers. For example, rules for the entry and operations of banks should not discriminate between domestic and foreign banks that are both properly qualified. Moreover, rules on the operations of public banks should not crowd out the activities of private banks. In addition, entry requirements for non-bank DSPs that restrict their activities to payments and transfer 
services should be minimal and only focus on ensuring that the DSP has adequate technical and operational capabilities. ${ }^{15}$ In view of the recent and still limited activity of non-bank DSPs in Latin America, this paper analyses only the rules of entry for non-bank electronic money issuers.

The indicator on market exit measures whether laws and regulations ensure that all types of non-viable financial service providers leave the market. This requires that the rules be specified on an ex-ante basis. For DSPs that restrict their activities to payments and transfer services, with limited (intraday) or no exposure to loss and small overall transaction volumes, exit rules can largely follow commercial bankruptcy rules and procedures. The situation is different for banks and DSPs whose activities go beyond payments and transfers. In these cases, there should be comprehensive rules for dealing with bank failures, beyond those of commercial rules.

When considering exit rules for traditional banks, the indicator is adjusted to assess whether countries' regulations have adopted the international standards advanced by the Financial Stability Board (FSB)'s Key Attributes for Effective Resolution Regimes. These standards were introduced after the global financial crisis and require major banks to prepare and implement living wills or recovery and resolution plans. These plans are written documents that need to outline how banks would regain viability under severe financial pressure and the steps that local regulators would take if the institutions should fail despite these steps.

The indicator on abuses of market power explores whether sound antitrust rules are in place in the financial sector to prevent the emergence of institutions with excessive market power. In a strong regulatory and supervisory environment, the antitrust regulator must possess the necessary tools and resources to evaluate the state of competition and must have the authority to break up monopolies and penalise collusive and uncompetitive pricing behaviour.

Finally, the indicator on contestability of inputs and interoperability seeks to assess: (a) whether rules and regulations facilitate the accessibility of the different inputs and networks needed for the production and distribution of financial services (at competitive prices and efficiently distributed) for those providers that choose to use them; and (b) whether regulation regarding interoperability among financial services networks, such that any user on any network can transact with any other, is appropriate. Adequate regulatory behaviour implies that interoperability should not be mandated from inception in order not to unnecessarily constraint market development and innovation (Claessens and Rojas-Suarez, 2016). Contestability and interoperability affect the behaviour of ATM networks, the networks of agents serving banks or non-bank DSPs and credit information systems.

\footnotetext{
15: As stated in Claessens and Rojas-Suarez (2016), for DSPs that engage in activities that pose risks to consumers and to the stability of the financial system, such as those providing stores of value not fully backed by safe assets, credit or insurance, higher entry standards should apply, including "fit and proper" entry rules and tests.
} 
The precise definition of each indicator forming the sub-index on Competition Policies, as well as the scoring methodology, is presented in Annex I.A. ${ }^{16}$

The main sources of information used for each country's score have come from: (a) national legislation, (b) the IMF's latest available Financial Sector Assessment Programme Reports (FSAPs); (c) the IMF/World Bank's latest Detailed Assessment of Compliance on the Basel Core Principles for Effective Banking Supervision; and (d) a number of papers and reports, including: IMF, Financial Integration in Latin America (2016) and Economist Intelligence Unit, Global Microscope (2015). Additional sources of information can be found under Other Sources in the References Section.

Table 2 shows results for the Competition Policies sub-index when applied to our sample countries. Annex II presents a summary table characterising each indicator for individual countries

16: The works of Bikker and Spierdijk (2009), Castellanos et al (2015), Claessens (2009) and Mirzaei and Moore (2014) have been useful in defining the criteria for scoring of the quality of competition policies. 
Table 2: The Sub-Index of Competition Policies in Selected Latin American

Countries. The Scores

\begin{tabular}{|c|c|c|c|c|c|c|c|c|c|}
\hline \multicolumn{2}{|c|}{ Criteria / Country } & Argentina & Brazil & Chile & Colombia & Mexico & Paraguay & Peru & Uruguay \\
\hline \multicolumn{2}{|c|}{ 1. Market Entry } & 1.3 & 1.3 & 2 & 2 & 1.3 & 1.7 & 1.7 & 1.3 \\
\hline $1 \mathrm{~A}$ & $\begin{array}{l}\text { Foreign bank } \\
\text { restrictions }\end{array}$ & 2 & 1 & 2 & 2 & 2 & 2 & 2 & 2 \\
\hline $1 \mathrm{~B}$ & State-bank ownership & 2 & 1 & 2 & 2 & 2 & 1 & 1 & 0 (a) \\
\hline & $\begin{array}{l}\text { Entry of Digital } \\
\text { Service Providers }\end{array}$ & 0 & 2 & 2 & 2 (b) & 0 & 2 & 2 & 2 \\
\hline \multicolumn{2}{|c|}{ 2. Market Exit } & 1.5 & 2 & 1.8 & 0.8 & 2 & 1.8 & 0.8 & 1.8 \\
\hline $2 \mathrm{~A}$ & Exit rules for banks & 2 & 2 & 2 & 2 & 2 & 2 & 2 & 2 \\
\hline & $\begin{array}{l}\text { Adjusted for alignment } \\
\text { with international } \\
\text { standards }\end{array}$ & 1.5 & 2 & 1.5 & 1.5 & 2 & 1.5 & 1.5 & 1.5 \\
\hline $2 \mathrm{~B}$ & $\begin{array}{l}\text { Exit of Digital Service } \\
\text { Providers }\end{array}$ & n.a. & 2 & 2 & 0 & n.a. & 2 & 0 & 2 \\
\hline \multicolumn{2}{|c|}{ 3. Abuses of market power } & 2 & 1 & 2 & 2 & 2 & 2 & 2 & 1 \\
\hline \multicolumn{2}{|c|}{$\begin{array}{l}\text { 4. Contestability of inputs } \\
\text { and interoperability }\end{array}$} & 2 & 1 & 1.3 & 2 & 2 & 1.3 & 2 & 1.3 \\
\hline $4 \mathrm{~A}$ & ATMs & 2 & 0 & 2 & 2 & 2 & 0 & 2 & 2 \\
\hline $4 \mathrm{~B}$ & Agents & n.a. & 1 & 0 & 2 & 2 & 2 & 2 & 0 \\
\hline $4 \mathrm{C}$ & Credit Information & 2 & 2 & 2 & 2 & 2 & 2 & 2 & 2 \\
\hline \multicolumn{2}{|c|}{$\begin{array}{l}\text { Competition policies Sub- } \\
\text { Index Score }\end{array}$} & 1.7 & 1.3 & 1.8 & 1.7 & 1.8 & 1.7 & 1.6 & 1.4 \\
\hline
\end{tabular}

n.a.: Not applicable.

(a) The Uruguayan banking sector is marked by a high degree of segmentation between public and private banks. This sector is dominated by a large public bank (Banco de la República Oriental de Uruguay, BROU) which has a monopoly on public employee accounts through a law that has given the public bank access to funding at very low cost. There is also evidence of significant differences in terms of supervisory practices between public and private banks.

(b) In November 2016, a draft Decree was issued that modified Law 1735 of 2014, amending the regulation on electronic money to allow non-bank issuers (or SEDPEs) to grant low-value credit (credito de bajo monto). This new regulation, if approved, might require SEDPEs to be subject to insolvency rules different from commercial bankruptcy laws. As of April 2017, this draft decree has been presented before Congress, but has not yet been debated.

Results from this sub-index show that regulatory strengths and weaknesses vary significantly across countries. A common characteristic among the highest performers (Argentina, Chile, Colombia, Mexico and Paraguay with a score of either 1.8 or 1.7) is that all countries received the maximum score in the indicator abuses of market power. Beyond that, the regulatory differences are large. For example, Chile and Colombia are very strong in entry policies, but while Chile's regulation on market exit are sound, Colombia's rules in this area need further consideration. In particular, the exit of digital financial services providers 
(DSPs) is subject to the same rules as other financial institutions, regardless of whether DSPs are involved in the provision of credit or not. The current view in the literature is that if DSPs restrict their operations solely to the provision of payment services, rules governing their exit should be those established by commercial bankruptcy rules. ${ }^{17}$ Peru (with an overall score of 1.6) shares with Colombia the same inadequacies as regards rules on market exit (where these countries obtain the lowest scores).

Another example of underlying differences between countries is the comparison between Mexico and Paraguay. While Mexico scores highly regarding contestability of inputs and interoperability, the country receives the lowest score (together with Argentina, Brazil and Uruguay) in market entry (1.3). This is because digital service providers are not allowed to enter the financial services market. The opposite result can be seen in the case of Paraguay. In this country, market entry regulations receive a high score, but there is limited interoperability among ATMs that might require government intervention. ${ }^{18}$

Argentina and Uruguay share relatively low scores on market entry, but for different reasons. In Argentina, DSPs are not allowed to offer digital financial services. In Uruguay, while there are no regulatory concerns about the entry of DSPs in financial services markets, competition issues arise due to the high degree of segmentation between public and private banks and there is evidence of significant monopoly power from a major public bank.

Brazil receives the lowest overall score (1.3) among countries in the sample, closely followed by Uruguay (1.4). Brazil displays low scores in market entry and abuses of market power, and the lowest score in the sample in contestability of inputs and interoperability. Some of the regulatory shortcomings include a complex legal framework for the opening of branches and subsidiaries of foreign banks that ultimately requires approval by the President. Moreover, the legislation does not clearly set out the responsibilities of the Central Bank and the competition authority about which entity is responsible for guaranteeing adequate competition in the banking system and avoiding abuses of market power by banks.

Finally, one interesting result from the table is that all countries receive the maximum score when assessing the unadjusted exit rules for banks. However, when these rules are adjusted for compliance with international standards, only Brazil and Mexico maintain this maximum score. In all other countries, banks are not required to prepare living wills or resolution/recovery plans to have ready in case of a potential eruption of severe banking problems.

\footnotetext{
17: In Colombia, electronic money is considered a deposit and, therefore, is subject to the same deposit insurance enjoyed by banks. This is a positive development. However, while electronic money issuers do not engage in lending operations and financial intermediation, their institutional characteristics will differ significantly from those of banks.

18: According to the World Bank (2014), achieving full interoperability between the two ATM networks operating in the country could significantly enhance financial inclusion in remote areas: One of the two ATM networks (BEPSA) serves Banco Nacional de Fomento which plays a major role in government-to-person payments; however, this network is not interoperable with Bancard, the ATM network which serves private banks.
} 


\section{b. Enabler 2: The Adequacy of the Supervisory Regime (Supervisory Quality)}

A robust oversight system of financial service providers is needed to ensure progress in financial inclusion in a sustainable manner. Most of the experience in Latin America and other emerging markets shows that weak oversight of providers of financial services, especially those involved in leverage activities, can result in severe instabilities in the financial system. ${ }^{19}$ Resolution of these instabilities have often led to a reversal of financial inclusion gains. Failure to address deficiencies in a country's oversight capacity could prevent the implementation of reforms that would foster increased market dynamism and greater financial inclusion, without endangering consumer protection and overall financial stability.

The Supervisory Quality sub-index is made up of two indicators: the supervisory powers indicator and the independence of supervisors' indicator. The first indicator, originally proposed by Barth, Caprio and Levine (2005), measures the degree to which a country's bank supervisory agency has the authority to take specific actions when necessary. The indicator is made up of eleven components, which assess the supervisors' capacity to: (a) meet with auditors and directly obtain relevant information from them, as well as taking legal action against them in cases of negligence; (b) obtain off-balance sheet information from banks and impose provisioning requirements to cover losses when needed; (c) take corrective actions on financial institutions in problems, including declaring the insolvency of supervised institutions, changing the organisational structure of banks, replacing managers and directors, reducing or suspending dividends to shareholders and bonuses to bank directors and managers, and superseding shareholders' rights.

Barth et. al. (2013) reported results on this indicator (among others on bank regulation and supervision) based on surveys, with a worldwide coverage, conducted by the World Bank. Unfortunately, the latest update of their survey is for the period 2011-12, with detailed information contained in the World Bank database (2012). Thus, to attach countries' scores we follow a two-step methodology. In the first step, we take the scores (rescaled) as reported by Barth et. al. (2013). In the second step, we examine whether amendments to the relevant legislation have been introduced since 2011. In countries where that is the case, we update the scores as compared to the 2013 version. These updated scores also follow the quantification criteria used by Barth et. al. If relevant legislation has not been amended after 2011, we maintain the original scores (rescaled) assigned by Barth et.al. (2013).

The independence of supervisors indicator assesses whether there is interference by political powers in the activities of the supervisory authorities. Scores for this indicator are directly taken from the latest Economic Intelligence Unit (EIU) Global Microscope report (2016) ${ }^{20}$

\footnotetext{
19: Latin American examples of deep financial crises and the consequent declines in the financial inclusion indicator abound, just in the 1990s and early 2000s, there were episodes in Argentina, Ecuador, Colombia, Mexico, Uruguay and Venezuela.

20: Question 2.2 in the 2016 EIU Global Microscope asks the following question: Is the financial regulator politically independent?
} 
Due to the importance of this indicator, it receives a weighting of 50 percent in the construction of the sub-index.

The definition of each indicator comprising the sub-index, the scoring methodology and the weightings assigned to all the components of the sub-index are presented in Annex I.B.

Annex III presents the specific questions and scoring methodology advanced by Barth et. al. (2013) and the EIU Global Microscope 2016. The annex also contains a table showing cases in which the results from Barth et. al. (2013) have been updated.

As mentioned above, the main sources of information used in scoring of each country has come from Barth et.al (2013), World Bank (2012) and the EIU (2016). National legislation was used when updates to the scores in Barth et. al. were needed.

Table 3 shows preliminary results for the Supervisory Quality sub-index when applied to the group of countries in our sample. Annex IV presents a summary table characterising each indicator for individual countries.

Table 3: The Sub-Index of Supervisory Quality in Selected Latin American countries. The Scores

\begin{tabular}{|c|c|c|c|c|c|c|c|c|c|}
\hline \multicolumn{2}{|c|}{ Criteria / Country } & Argentina & Brazil & Chile & Colombia & Mexico & Paraguay & Peru & Uruguay \\
\hline 1 & Supervisory Powers & 1.4 & 1.9 & 2 & 1.3 & 1.7 & 2 & 2 & 2 \\
\hline $1 \mathrm{~A}$ & $\begin{array}{l}\text { Meeting with external } \\
\text { auditors }\end{array}$ & 2 & 0 & 2 & 2 & 2 & 2 & 2 & 2 \\
\hline 1B & $\begin{array}{l}\text { Be informed about } \\
\text { illicit activities, fraud, } \\
\text { insider abuse }\end{array}$ & 0 & 2 & 2 & 2 & 2 & 2 & 2 & 2 \\
\hline $1 \mathrm{C}$ & $\begin{array}{l}\text { Act against external } \\
\text { auditors }\end{array}$ & 2 & 2 & 2 & 2 & 2 & 2 & 2 & 2 \\
\hline $1 \mathrm{D}$ & $\begin{array}{l}\text { Change } \\
\text { organisational } \\
\text { structure of banks }\end{array}$ & 0 & 2 & 2 & 2 & 2 & 2 & 2 & 2 \\
\hline $1 \mathrm{E}$ & $\begin{array}{l}\text { Impose provisioning } \\
\text { requirements }\end{array}$ & 2 & 2 & 2 & 2 & 2 & 2 & 2 & 2 \\
\hline $1 \mathrm{~F}$ & $\begin{array}{l}\text { Disclosure of off- } \\
\text { balance sheet items }\end{array}$ & 2 & 2 & 2 & 2 & 2 & 2 & 2 & 2 \\
\hline $1 G$ & Suspend dividends & 2 & 2 & 2 & 0 & 2 & 2 & 2 & 2 \\
\hline $1 \mathrm{H}$ & $\begin{array}{l}\text { Suspend bonuses and } \\
\text { management fees }\end{array}$ & 0 & 2 & 2 & 0 & 2 & 2 & 2 & 2 \\
\hline $1 \mathrm{I}$ & $\begin{array}{l}\text { Declare bank } \\
\text { insolvency }\end{array}$ & 2 & 2 & 2 & 2 & 2 & 2 & 2 & 2 \\
\hline $1 \mathrm{~J}$ & $\begin{array}{l}\text { Supersede } \\
\text { shareholders' rights }\end{array}$ & 2 & 2 & 2 & 0 & 1 & 2 & 2 & 2 \\
\hline $1 \mathrm{~K}$ & $\begin{array}{l}\text { Replace managers } \\
\text { and directors }\end{array}$ & 2 & 2 & 2 & 2 & 1 & 2 & 2 & 2 \\
\hline 2 & $\begin{array}{l}\text { Independence of } \\
\text { the Supervisor }\end{array}$ & 0 & 1 & 1 & 1 & 1 & 2 & 2 & 1 \\
\hline $\begin{array}{l}\text { Supe } \\
\text { Inde. }\end{array}$ & $\begin{array}{l}\text { Scrvisory Quality Sub- } \\
x \text { Score }\end{array}$ & 0.7 & 1.5 & 1.5 & 1.2 & 1.4 & 2 & 2 & 1.5 \\
\hline
\end{tabular}


In Latin America, countries differ regarding the institution in charge of financial supervision. In Argentina, Brazil, Paraguay and Uruguay, the central bank has the mandate of supervising banks. In Chile, Colombia, Mexico and Peru, the supervisory authority is established as a separate entity. This difference, however, does not seem to affect the results on the quality of supervisory activities. For example, on an overall basis, Peru (where a separate, independent agency is in charge) and Paraguay (where the Central Bank supervises financial institutions) stand out as the strongest countries in terms of the quality of the supervisory regime: these two countries receive the maximum score in all the components of the subindex.

By contrast, Argentina gets a very low overall score (0.7) and the last position in the sample. One important reason for this low score is that current legislation does not ensure the independence of the supervisor from political influence. Particularly noteworthy is that there are no criteria in the law for the removal of the superintendent of supervision ${ }^{21}$ and there are no requirements for the reasons to be made public. Moreover, the superintendent is appointed for a three-year term while Central Bank's Governors are appointed for 6 years. Other reasons affecting Argentina's overall score are that: (a) bank auditors are not required to communicate directly to the superintendent any presumed involvement of bank directors or senior managers in illicit activities, fraud or insider abuse; (b) the supervisor lacks authority to order a bank to change its internal organisation structure; and (c) the supervisor cannot require banks to reduce or suspend bonuses paid to bank directors and managers.

In the rest of countries in the sample (Brazil, Chile, Colombia, Mexico and Uruguay), the scores from the Global Microscope (2016) also signal evidence of insufficient independence of the supervisor, albeit to a lesser extent than in Argentina. For example, in Chile the Superintendent is appointed by the President and can be dismissed by him/her without having to show cause; and in Uruguay there is no clarity in the law about the scope of the supervisory authority's technical and operational authority. ${ }^{22}$

Regarding the indicator on supervisory powers, Chile and Uruguay join Peru and Paraguay in obtaining a perfect score. Brazil and Mexico follow close behind (with scores of 1.9 and 1.7 respectively). Relatively speaking, Colombia is well behind with a score of 1.3. The reason for Colombia's lower score is that supervisors in this country do not have the power to: (a) reduce or suspend bonuses and remunerations to bank directors and managers; or (b) supersede shareholders' rights. Following Barth et. al. (2013), these two components have a higher weighting than most others in the supervisory powers indicator (see Annex I.B).

Beyond the specific scores for individual countries, it is important to notice that many countries in the region have made significant progress in the quality of supervision during

\footnotetext{
21: The Central Bank of Argentina conducts financial supervision through the SEFyC (Superintendencia de Entidades Financieras y Cambiarias). The Superintendent reports directly to the Board of Directors of the Central Bank of the Republic of Argentina (BCRA).

22: The SSF (Superintendencia de Servicios Financieros) operates in the Central Bank of Uruguay (BCU) and reports to the Board of Directors of the BCU.
} 
the 2000s. This can be shown by comparing the values of the scores in the survey results from Barth et. al. in 2003 versus those in $2011 .^{23}$ Indeed, as seen in the footnote, with the exception of Colombia (and Paraguay, which did not participate in the 2003 survey), the scores for the variable "official supervisory powers" increased in Argentina, Chile, Mexico, Peru and Uruguay. The score stayed constant in Brazil at a high value.

\section{The Enablers Index}

Table 4 presents the Enablers index and its components. The value of the overall index is the simple average of the scores obtained for the two sub-indices

Table 4: The Enablers Index in Selected Latin American Countries. The Scores

\begin{tabular}{|l|c|c|c|c|c|c|c|c|}
\hline Criteria / Country & Argentina & Brazil & Chile & Colombia & Mexico & Paraguay & Peru & Uruguay \\
\hline Competition policies & 1.7 & 1.3 & 1.8 & 1.7 & 1.8 & 1.7 & 1.6 & 1.4 \\
Supervisory quality & 0.7 & 1.5 & 1.5 & 1.2 & 1.4 & 2 & 2 & 1.5 \\
\hline Enablers Score & 1.2 & 1.4 & 1.7 & 1.5 & 1.6 & 1.9 & 1.8 & 1.5 \\
\hline
\end{tabular}

With a score of 1.9, Paraguay achieves the highest score in the Enablers index. Peru, Chile and Mexico (with scores of 1.8, 1.7 and 1.6 respectively) and Mexico are not far behind. While the soundness of Competition Policies is the main source of strength in Chile and Mexico, a perfect score in Supervisory Quality supports the overall results in Peru.

Brazil, Colombia and Uruguay achieve lukewarm results. In Brazil, the score for Competition Policies is the lowest among the countries in the sample. In Colombia, the strength of its Competition Policies cannot offset its weakness in the sub-index of Supervisory Quality. Uruguay's results are more balanced, with the two sub-indices reaching similar scores.

With a score of only 1.2, Argentina occupies the last position among the countries in the sample. In this country, significant efforts are needed if the regulatory framework is going to enable progress in financial inclusion.

23

\begin{tabular}{l|c|c|c|c|c|c|c|c} 
& Argentina & Brazil & Chile & Colombia & Mexico & Paraguay & Peru & Uruguay \\
\hline $\begin{array}{l}\text { Official Supervisory Powers, } \\
\text { 2003, rescaled }\end{array}$ & 1.1 & 1.9 & 1.6 & 1.9 & 1.3 & n.a. & 1.7 & 1.7 \\
$\begin{array}{l}\text { Official Supervisory Powers, } \\
\text { 2011, rescaled }\end{array}$ & 1.3 & 1.9 & 2 & 1.3 & 1.7 & 1.3 & 2 & 2
\end{tabular}

n.a.: not available

Source: World Bank Regulation and Supervision Surveys, Survey II and Survey IV 


\section{Assessing Regulations classified as Promoters of Financial Inclusion}

This section analyses the six regulatory practices classified as Promoters in Table 1. As stated previously, while the set of regulations discussed here is not exhaustive, they are representative of practices followed in Latin American countries. As with the Enablers, the indicators forming each of the Promoters sub-indices are identified, the scoring system is defined and scores are attached to the countries in our sample.

Promoters consist of regulatory frameworks that allow and encourage the usage of specific financial products and services. Stemming from the interrelationships between these frameworks and other regulations and policies, there are three features that impinge on the construction of the scoring system. The first is that the power of a Promoter as a financial inclusion tool is affected by some characteristics of the overall regulatory environment (the Enablers). For example, Competition Policies impact the efficacy of the regulatory frameworks for Simplified Accounts and Electronic Money: while it is desirable for these frameworks not to impose restrictions on fees and commissions charged by the suppliers of these products, this desirability holds only as long as adequate Competition Policies drive a healthy degree of competition between providers in the system. If, in contrast, entrenched monopoly powers control the supply of products, it is reasonable to expect regulatory actions to rein in the cost of accessing these products.

A second feature affecting the construction of the scoring system is that the effectiveness of a number of Promoters can be enhanced by additional government efforts. For example, by fostering the payment of salaries, pensions and other workers' benefits through deposits in Simplified Accounts, the usage of this product is encouraged among individuals in the formal sector. If in addition, transfers from social programmes are also made through deposits in Simplified Accounts or Electronic Money accounts, recipients in the informal sector will be encouraged to use these financial products.

In spite of these efforts, however, there is evidence that the usage by the poor of payments and savings products offered by the formal financial system is limited to the periodic withdrawal of the money received. Lack of financial literacy has often been identified as the reason behind this occurrence, as the owners of these accounts often do not know how to use their accounts for purchases, utility payments or savings. A similar argument applies to microcredit and the usage of other financial services, such as access to the credit information collected by credit reporting systems. This brings us to the third feature affecting the scoring system, namely policies on financial literacy. Indeed, financial literacy affects the outcomes of all regulatory Promoters, and, therefore, the scoring of the overall Promoters Index.

Thus, while the first two features are integrated in the construction of individual Promoters sub-indices, a variable which reflects practices regarding financial literacy is used to adjust the value of the overall Promoters Index. Details on the construction of the scoring system for the Promoters are explained in the sections that follow and in Annex I. 


\section{a. Promoter 1: Simplified Accounts}

Simplified accounts, accounts with limits on balances and transactions and that are subject to streamlined KYC requirements, can serve the dual purpose of protecting financial integrity and encouraging financial inclusion. Many poor people are unable to provide burdensome forms of documentation, such as proof of address and sources of income, which are usually required to open regular bank accounts. Thus, a regulatory framework establishing the characteristics of Simplified Accounts to be used by low-income populations should waive these requirements so that a basic form of legal identification may suffice. Also, a regulatory framework that facilitates the affiliation to these accounts through non-traditional channels, such as correspondents, or via electronic means, can help reduce transaction costs in the provision of formal financial services of remote populations, especially in rural areas.

To assess the quality of the regulatory practices and policies for Simplified Accounts, we use two sets of indicators. The first set is formed by minimum regulatory standards for the provision of these services. The second set includes government efforts that can enhance the inclusive capacity of these accounts.

The set of indicators defining minimum regulatory standards (eight indicators in total) corresponds to characteristics of clients and providers that can offer the accounts as well as identification requirements, approved channels for providing these accounts, limits on individual account balances and transactions and on the number of accounts that may be held by a single customer (individual or firm), and the regulatory stance regarding the charging of fees and commissions. Several of these indicators are taken from CAF et. al. (2013), which conducts a comprehensive study on this subject.

Out of the 8 indicators in this set, the fees and commissions variable deserves special attention. The accepted view is that an appropriate regulatory framework for Simplified Accounts imposes no restrictions on fees and commissions for opening or maintaining these accounts or performing transactions. The argument is that these types of restrictions could render the business of offering these accounts unviable and act as a disincentive to the design of inclusive business models. We agree with this view, but add a caveat. Unrestricted fees and commissions are desirable in the context of adequate Competition Policies that prevent the exercise of monopoly powers. In the presence of monopolistic behaviour, a second best solution calls for the imposition of certain limits on fees and commissions to avoid unduly high pricing. ${ }^{24}$ In order to take this caveat into account, we have constructed an adjusted fees and commissions variable, which takes into account the value of the sub-index Competition Policies, discussed in Section III.

The list of indicators defining minimum regulatory standards and the scoring methodology, including that used for the indicator, adjusted fees and commissions, is presented in Annex I.C.

The second set of indicators includes additional forms of government intervention that promote the usage of Simplified Accounts. These additional efforts include (but are

24: The first best solution is, of course, a reform in competition rules and regulations. 
not restricted to) requirements for depositing payments of wages, pensions or other forms of remunerations into simplified accounts. They also include the depositing of government transfers to low-income populations into these accounts. Ideally, these additional efforts should benefit populations in both the formal and the informal sector. To capture the importance of supporting financial inclusion in the informal sector, rather than creating one indicator for each type of deposit, we have collapsed these different indicators into one, additional government efforts, and assigned three possible scorings: 0 if the government has not conducted any interventions to improve the usage of simplified accounts; 1 if there are government interventions of the type described above and they benefit the formal sector only; and 2 if government interventions benefit both the formal and informal sectors.

As with the fees and commissions indicator, a caveat is necessary to better understand the role of the additional government efforts indicator. These interventions can best achieve their desired objective of enhancing financial inclusion if they do not generate distortions and do not crowd out services offered by the private sector. An example of crowding out arises if the payment of salaries and benefits through Simplified Accounts are made through compulsory deposits in public banks only, potentially displacing services that could be offered by private banks. To take this caveat into account, we have constructed an indicator entitled adjusted additional government efforts, which takes a lower value than the unadjusted indicator if the regulatory interventions involve crowding out effects. The scoring methodology for this indicator is presented in Annex I.C.

The Annex also describes the weighting system used to obtain the overall scoring for the Simplified Accounts sub-index.

The main sources of information used in scoring of each country are national legislation, CAF et. al. (2013) and the additional sources listed in the Reference Section.

Table 5 shows the results for the Simplified Accounts sub-index as applied to the group of Latin American countries. Annex VI presents a summary table highlighting characteristics of each indicator for individual countries. 
Table 5: The Sub-Index of Simplified Accounts in Selected Latin American countries. The Scores

\begin{tabular}{|c|c|c|c|c|c|c|c|c|}
\hline Criteria/ Country & Argentina & Brazil & Chile & Colombia & Mexico & Paraguay & Peru & Uruguay \\
\hline \multicolumn{9}{|c|}{ 1. Minimum regulatory standards } \\
\hline 1 Regulatory framework & 2 & 2 & 0 (a) & 2 & 2 & 2 & 2 & 1 \\
\hline 2 Clients & 0 & 0 & 0 & 0 & 2 & 0 & 0 & 2 \\
\hline 3 Providers & 2 & 0 & 0 & 1 & 2 & 0 & 2 & 3 \\
\hline $4 \begin{array}{l}\text { Permitted channels for } \\
\text { provision }\end{array}$ & 1 & 1 & 1 & 2 & 2 & 2 & 2 & 4 \\
\hline $5 \begin{array}{l}\text { Identification } \\
\text { requirements }\end{array}$ & 2 & 2 & 2 & 2 & 2 & 2 & 2 & 5 \\
\hline 6 Transactional limits & 1 & 2 & 1 & 1 & 2 & 2 & 1 & 6 \\
\hline $\begin{array}{l}7 \begin{array}{l}\text { Limits to the number of } \\
\text { accounts }\end{array}\end{array}$ & 1 & 1 & 2 & 2 & 1(b) & 1 & 1 & 7 \\
\hline 8 Fees and commissions & 0 & 0 & 2 & 2 & 0 & 0 & 2 & 8 \\
\hline $\begin{array}{l}\text { 8. a Adjusted fees and } \\
\text { Commissions (for quality } \\
\text { of competition policies) }\end{array}$ & 0 & 0 & 2 & 2 & 0 & 0 & 2 & 2 \\
\hline Score Set 1 & 1.1 & 1 & 1 & 1.5 & 1.6 & 1.1 & 1.5 & 1.5 \\
\hline \multicolumn{9}{|c|}{ 2. Additional government efforts } \\
\hline 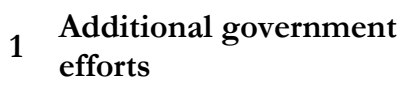 & 2 & 2 & 2 & 2 & 1 & 2 & 2 & 1 \\
\hline $\begin{array}{l}\text { Adjusted additional } \\
\text { government efforts (for } \\
\text { crowding out) }\end{array}$ & 2 & 0.5 & 2 & 2 & 0 & 0.5 & 0.5 & 0 \\
\hline Score Set 2 & 2 & 0.5 & 2 & 2 & 0 & 0.5 & 0.5 & 0 \\
\hline $\begin{array}{l}\text { Simplified Accounts Sub- } \\
\text { Index Score }\end{array}$ & 1.5 & 0.8 & 1.4 & 1.7 & 1 & 0.9 & 1.1 & 0.9 \\
\hline
\end{tabular}

Note: the term simplified accounts is not used in all countries; sometimes they are called basic accounts or simple accounts. Annex V states the specific name of the account, the regulator in charge and the applicable regulation in each country.

(a) Simplified accounts do not exist under Chilean regulations. However, Banco Estado created a product, CuentaRUT, associated to the individual's ID Number (Rol Único Tributario) that has similar characteristics to simplified accounts. The assessment on indicators 2-8 was based on this account. This product is subject to regulation on sight accounts, and therefore does not pay interest. Under this framework, any bank in Chile could in principle offer this type of account, but apart from Banco Estado no other bank has decided to launch this product. According to FOMIN (2015), approximately 40 percent of the Chilean population holds a CuentaRUT.

(b) In Mexico, the regulation does not impose a limit on the number of accounts, but instead transactional limits are assigned per client, per financial institution. This is assessed to mitigate the absence of limits to the number of accounts (CAF et al, 2013) and is why the country scores 1 instead of 0. 
Assessments of Simplified Accounts show large divergence between countries. In terms of minimum regulatory standards, no country receives a perfect score, but Mexico (with a score of 1.6) and Colombia, Peru and Uruguay (with a score of 1.5) perform best. Mexico's most important reason for losing points is that there are restrictions on the fees charged for the provision of certain services. ${ }^{25}$ An important shortcoming for most countries in the sample (including Colombia and Peru) is that small companies are not allowed to hold Simplified Accounts. Indeed, the only two exceptions are Mexico and Uruguay.

The lowest scores in minimum regulatory standards are attained by Brazil and Chile (with a score of 1.0) and Argentina and Paraguay (with a score of 1.1). Deficiencies in the scope of which clients may open Simplified Accounts and/or in which providers are permitted to offer these accounts; and/or restrictions on fees and commissions charged to opening and maintaining the accounts explain the low scores. In the case of Chile, there is no dedicated regulatory framework for Simplified Accounts, but BancoEstado has created a product (Cuenta RUT) with similar characteristics. This type of account could be offered by other financial institutions. However, to date there are no takers among other financial institutions. ${ }^{26}$

For all countries, the score of the adjusted fees and commissions indicator equals that of the unadjusted indicator. This is because the values of the Competition Policies scores are all greater than 1. In other words, while there is a clear need for improvement in the competition framework in a number of countries (see Section III), in no country were these weaknesses so strong as to encourage the entrenchment of monopolistic powers.

In terms of additional government efforts, all countries but Uruguay have attempted to support these accounts through existing conditional cash transfer programmes (Bolsa Familia in Brazil, Mas Familias en Acción (MFA) in Colombia, Chile Cuenta in Chile, PROSPERA in Mexico, Tekopora in Paraguay and Juntos in Peru). Also, in Argentina, payment of subsidies and Government transfer programmes is done through cajas de aborros, the simplified accounts. Not so encouraging, however, is the fact that in a number of countries in the sample, there is evidence of crowding out effects. For example, in Brazil, payments under the Bolsa Familia programme can only be made through the public bank Caixa Economica; in Mexico, payments under the PROSPERA programme can only be made through Bansefi, a development bank selected by the Board of the government programme Oportunidades; By contrast, in Colombia, all supervised financial institutions may obtain licenses for taking deposits under the $M F A$ programme.

The overall scores, when the indicators of minimum regulatory standards and additional government efforts are combined, indicate the strength of Colombia (with a score of 1.7) among the countries in the sample. In this sub-index, Brazil (closely followed by Paraguay, Uruguay and

\footnotetext{
25: In particular, financial institutions cannot charge for money withdrawals from their own ATM networks. 26: Private banks argue that offering the product is not profitable. These might be caused by the absence of a dedicated regulatory framework, but it is also alleged that it is difficult to offer the product as part of a package of banking products. Also, Jorge Rodríguez, Chairman of BancoEstado has stated that CuentaRUT generates significant losses for the bank, adding that this situation is unsustainable in the medium term (LaTercera.com, 2016)
} 
Mexico) obtains the lowest scores. Despite their high rankings when only the set of indicators reflecting minimum regulatory standards was considered, the lack of additional government efforts in Uruguay and the presence of crowding out effects in Mexico adversely affect these countries' overall scores.

\section{b. Promoter 2: Electronic Money}

Electronic Money can be broadly defined as "a record of funds or value available to consumers stored on a payment device, such as a chip, a prepaid card, or a mobile phone, or on a computer system as a non-traditional account with a banking or non-banking entity" (World Bank, 2012, p. 104). As stated in Claessens and Rojas-Suarez (2016), Electronic Money and other advances in digital financial services have the potential to contribute significantly to three features of financial inclusion: the expansion of financial services to reach large segments of the population (availability), at low cost (affordability), and in an efficient and safe manner (quality). ${ }^{27}$

Electronic Money in developing countries has mostly taken the form of mobile money (records of funds that are stored in mobile phones) used for payments and transfers. While mobile money is quite widespread in a number of countries, especially in Sub-Saharan Africa, its usage is limited, albeit increasing, in Latin America. As more countries in the region are issuing regulations for the offering of Electronic Money, it is crucial to ensure that the regulatory framework for the provision of this service meets high standards.

The assessment of the quality of regulatory policies and practices for Electronic Money follows a similar methodology to that employed for Simplified Accounts. As such, our analysis uses two sets of indicators: the first set is made up of indicators defining minimum regulatory standards and the second set includes government efforts that enhance the usage of Electronic Money.

The set of indicators defining minimum regulatory standards ( 8 indicators in total) identifies whether there is a dedicated regulatory framework for electronic money and assesses whether rules and regulations for providers and their network of agents guarantee a level playing field among the different suppliers and safeguard the stability of the financial system. The indicators also address: regulatory requirements for interoperability between networks of providers; identification requirements for the provision of the service; the regulatory stance on fees and commissions charged for the provision of the service; and regulatory requirements to safeguard consumers' funds. This last indicator assesses whether the provider can meet customers' demands for cash at all times and whether customers' funds are protected from possible insolvency either of the issuer or of the bank in which the issuer has deposited the funds. Several of these indicators are taken from GSMA (2016) and di Castri (2013).

\footnotetext{
27: It is important to differentiate electronic money from electronic banking. While the former does not necessitate customers to hold a bank account, the latter requires individuals to have a bank account in order to use mobile phones and the internet to perform financial transactions.
} 
As with Simplified Accounts, the indicator on fees and commissions interacts with the quality of Competition Policies. That is, we construct an adjusted fees and commissions indicator, which takes into account the value of the Competition Policies sub-index discussed in Section III. ${ }^{28}$

The precise definition of the indicators for minimum regulatory standards, along with the scoring methodology, is presented in Annex I.D.

The second set of indicators, which involves additional forms of government interventions that enhance the usage of Electronic Money, is identical to the indicators for Simplified Accounts, including an adjustment for the possibility of crowding out. Therefore, no further explanation of these indicators is needed. The scoring methodology for these indicators is presented in Annex I.D. This Annex also describes the weighting system used to obtain the overall scoring for the Electronic Money sub-index.

The main sources of information used in the score for each country are national legislation and the additional sources listed in the Reference Section.

Table 6 shows the results for the Electronic Money sub-index as applied to our sample of countries. Annex VIII presents a summary table highlighting characteristics of each indicator for individual countries.

\footnotetext{
28: Alternatively, we could have made the indicator of fees and commissions interact with the indicators characterising entry and interoperability requirements for providers of Electronic Money. Our preference for using the sub-index on Competition Policies is due to the fact that this sub-index includes other relevant factors such as the quality and enforcement of antitrust rules.
} 
Table 6: The Sub-Index of Electronic Money in Selected Latin American countries.

The Scores

\begin{tabular}{|c|c|c|c|c|c|c|c|c|c|}
\hline \multicolumn{2}{|c|}{ Criteria / Country } & Argentina & Brazil & Chile & Colombia & Mexico & Paraguay & Peru & Uruguay \\
\hline \multicolumn{10}{|c|}{ 1. Minimum regulatory standards } \\
\hline 1 & Regulatory framework & 0 (a) & 2 & 2 & 2 & $0(\mathrm{~b})$ & 2 & 2 & 2 \\
\hline 2 & Providers & n.a. & 2 & 2 & 2 & n.a. & $1(d)$ & 2 & 2 \\
\hline 3 & $\begin{array}{l}\text { Delimitation of } \\
\text { activity }\end{array}$ & n.a. & 2 & 2 & 2 & n.a. & 2 & 2 & 2 \\
\hline 4 & $\begin{array}{l}\text { Identification and } \\
\text { verification } \\
\text { requirements }\end{array}$ & n.a. & 2 & $0(\mathrm{c})$ & 2 & n.a. & 2 & 2 & 1(e) \\
\hline 5 & Use of agents & n.a. & 2 & $0(c)$ & 2 & n.a. & 2 & 2 & 1 \\
\hline \multirow[t]{4}{*}{6} & Protection of funds & n.a. & 2 & 1.3 & 2 & n.a. & 1.3 & 2 & 1.3 \\
\hline & 6A Liquidity & -- & 2 & 2 & 2 & -- & 2 & 2 & 2 \\
\hline & $\begin{array}{l}\text { 6B Protection against } \\
\text { issuer's insolvency }\end{array}$ & -- & 2 & 2 & $2(f)$ & -- & 2 & 2 & 2 \\
\hline & $\begin{array}{l}\text { 6C Protection against } \\
\text { bank's insolvency }\end{array}$ & -- & 2 & $0(\mathrm{c})$ & 2 & -- & 0 & 2 & 0 \\
\hline 7 & Interoperability & n.a. & 2 & 1 & 1 & n.a. & 2 & 2 & 1 \\
\hline 8 & Fees and commissions & n.a. & 2 & 2 & 2 & n.a. & 0 & 2 & 0 \\
\hline & $\begin{array}{l}\text { 8. a Adjustment fees and } \\
\text { commissions (for quality } \\
\text { of competition) }\end{array}$ & -- & 2 & 2 & 2 & -- & 0 & 2 & 0 \\
\hline \multicolumn{2}{|c|}{ Score Set 1} & 0 & 2 & 1.3 & 1.9 & 0 & 1.5 & 2 & 1.3 \\
\hline \multicolumn{10}{|c|}{ 2. Additional government efforts } \\
\hline & $\begin{array}{l}\text { Additional } \\
\text { government efforts } \\
\text { Adjusted additional } \\
\text { government efforts (for } \\
\text { crowding out) }\end{array}$ & n.a. & 0 & 0 & 2 & n.a. & 2 & 1 & 2 \\
\hline \multicolumn{2}{|c|}{ Score Set 2} & n.a. & 0 & 0 & 2 & n.a. & 2 & 1 & 2 \\
\hline \multicolumn{2}{|c|}{$\begin{array}{l}\text { Electronic Money Sub- } \\
\text { Index Score }\end{array}$} & 0 & 1.2 & 0.8 & 1.9 & 0 & 1.7 & 1.6 & 1.6 \\
\hline
\end{tabular}

n.a.: not applicable.

Note: the term electronic money is not used in all countries; sometimes the service is called electronic means of payment or electronic payments and deposits. Annex VII states the specific name of the product, the regulator in charge and the applicable regulation in each country

(a) There is no specific regulation on electronic money in Argentina as of April 2017

(b) There is no specific regulation on electronic money in Mexico as of April 2017, although the Government is working on a new law to regulate the Fintech sector (the Fintech Law) that will regulate this instrument. This Law expected later this year (El Law 20950 of October 2016 that regulated the issuance of prepaid cards by non- 
bank institutions mandated the Central Bank of Chile to issue additional regulations containing several technical details on the operations of such institutions. Following this mandate, in March 2017 the Central Bank launched a public consultation on a proposal to consolidate existing rules on payment cards, including capital and liquidity requirements for non-bank issuers of prepaid cards, rules to deal with operational risks and the requirements and limits for the offering of different types of prepaid cards. This proposal has not yet been formally adopted as of April 2017.

(d) In Paraguay, the Resolution that regulates EMPEs (Empresas de Medio de Pago Eelectrónico) does not deal with electronic payment services conducted by banks or financial companies. Therefore, depending on the provider, funds can be intermediated and generate interest payments.

(e) Simplified KYC requirements apply to e-money accounts for the payment of remunerations, social benefits and pensions. However, even under this simplified regime, individuals are required to provide proof of enrolment with the relevant social security agency and an estimation of monthly income. Other e-money services and products are not subject to any form of due diligence procedures.

(f) There is no specific provision on ring-fencing, but since e-money in Colombia is defined as a deposit, and funds are covered directly by the Deposit Guarantee Scheme, customer funds seem to be protected in case of the issuer's insolvency.

Regulation on electronic money is quite new in the region and some countries have either not issued regulations (as in the case of Argentina and Mexico) or the regulations are still incomplete (as in the case of Chile). Due to the lack of regulation at the time of writing, Argentina and Mexico received a score of zero. There are some signs of progress, though. For example, in Argentina, over the last year, the Central Bank has issued some regulations related to electronic payments for banks. ${ }^{29}$ Among other things, these rules allow banks to use mobile phones as "mobile wallets" linked to banks' sight accounts. In Mexico, a special type of banking license, subject to lighter capital requirements (Bancos de nicho) was created in 2009. They are allowed to offer electronic deposits, through a level 1 account. These deposits are considered no different from regular deposits. However, the Government has been working on a Law to regulate the Fintech sector in Mexico, which is expected later this year. Among other issues, the new "Fintech Law" will regulate electronic money (El Financiero, 2017).

In Chile, there is a dedicated regulatory framework for electronic money. A decree allowing non-bank institutions to also issue prepaid cards received final approval in August 2016 and entered into force in October 2016. However, technical details (such as the use of agents, requirements to obtain a prepaid card and providers' capital requirements) are to be defined in additional regulation to be issued by the Central Bank, as mandated in the aforementioned legislation. ${ }^{30}$ Due to these shortcomings, Chile's score only reaches 1.3.

\footnotetext{
29: Apart from these recent advances, Resolution 300/2014 of the Financial Information Unit provided a first approach to the concept of electronic money in the Argentinian legislation. However, as noted by Eraso (2016), the purpose of this is just to provide a conceptual definition of the instrument, not to regulate its functioning. Eraso also insists on the need to develop a specific regulatory framework for electronic money in order to capture its full potential.

30: Regulatory guidance on fees and commissions is also still pending. However, we have assigned a score of 2 to the indicator fees and commissions since the current regulatory framework does not impose any restrictions to fees and commissions for opening or maintaining electronic money or undertaking transactions that limit providers' ability to design viable product.
} 
Among the rest of countries in the sample, the assessment on the set of indicators minimum regulatory standards (Set 1 ) shows that three countries distinguish themselves as very high performers: Peru and Brazil, with a perfect score, and Colombia with a score of 1.9. ${ }^{31}$

Paraguay and Uruguay's performance leaves room for improvement (scores of 1.5 and 1.3 respectively). In the case of Paraguay, a regulatory prohibition on the charging of fees for converting electronic money back to $\operatorname{cash}^{32}$; the absence of provisions to safeguard customers' funds against the insolvency of the banks in which the provider has deposited these funds; and some distortions in the level playing field between bank and non-bank suppliers of electronic money hurt the score. In the case of Uruguay, suppliers are prohibited from charging commissions for opening, maintaining or withdrawing funds from electronic money accounts; there are no provisions to safeguard customers' funds against insolvency of the banks in which the funds are placed and KYC requirements can be simplified further. ${ }^{33}$

In terms of the indicator of additional government efforts (Set 2), in contrast to Simplified Accounts, only 4 countries have put in place programmes to support the development of electronic money. Social programmes, such as Mas Familias en Acción (MFA) in Colombia, can make payments through electronic deposits ${ }^{34}$; conditional transfer payments through Tekopora in Paraguay can be made using an electronic wallet; and the Law of Financial Inclusion in Uruguay allows workers, recipients of pensions or other beneficiaries to receive payments in electronic money instruments issued by banks, cooperatives and e-money issuers. In Peru, although payment of social benefits (Juntos, Pension 65 or Beca 18) using electronic money is still under consideration, there are certain taxes that can be paid through the electronic wallet BIM. ${ }^{35}$ In all the countries where additional government efforts are in place, there are no indications of crowding out effects on other products or institutions.

When the overall scoring is calculated, Colombia stands out with a score of 1.9. Paraguay takes second position (with a score of 1.7); Uruguay is tied with Peru in third place with a score of 1.6 and Brazil is left in fourth position (with a score of 1.2). All these changes in overall positions, compared to the scores when only the indicator on minimum regulatory standards was considered, reflect differences in countries' efforts to promote the use of electronic money. Because of the absence or lack of completion of regulation governing the activities of electronic money, Argentina, Mexico and Chile remained in the bottom three positions in the ranking.

\footnotetext{
31: As in the case of Simplified Accounts, for all the countries the score of the adjusted fees and commissions indicator equals that of the unadjusted indicator. This is because the scores of the sub-index on Competition Policies are all greater than one.

32: Prohibiting providers to charge fees on cash-out transactions generates incentives for providers to increase fees on other services. See UNCTAD (2012)

33: Also, in Uruguay, there is no regulatory guidance about interoperability.

34: As indicated in a footnote in the table, e-money in Colombia is defined as deposits

35: In particular, since November 2016 the RUS, a simplified tax for self-employed taxpayers and microbusinesses can be paid through BIM
} 


\section{c. Promoter 3: Correspondents}

Correspondents are non-financial entities engaged by financial institutions to provide financial services to low-income individuals, especially those located in remote and/or low population density areas. Through this business model, financial institutions avoid establishing branches or maintaining ATMs in locations where the latter delivery mechanisms would be unprofitable. By becoming access points to the formal financial system, correspondents support financial inclusion. As noted by Camara et. al. (2015), correspondents take the form of retail establishments that can belong to a broad range of sectors (grocery, gas stations, postal services, pharmacies, etc.), as long as they are bricks-and-mortar stores whose core business involves managing cash. ${ }^{36}$ In their most basic version, correspondents carry out only transactional operations (cash in, cash out and bill payments) but in many cases they have evolved to serve as a distribution channel for financial institutions' credit, saving and insurance products. The denomination used to refer to these establishments differs by country. Annex IX states the specific name given in each country to banking correspondents and the applicable legislation. For simplicity, we will refer to all of them here as "correspondents" or "agents".

It is important to emphasise that the term correspondents refers to any agent that acts on behalf of an institution that offers financial services, regardless of whether it is a bank or other type of institution (credit cooperatives, microfinance institutions, e-money provider, etc.). In this regard, the assessment of the quality of correspondents in this section also complements the discussion on usage of agents by electronic money providers presented in the previous section.

The Correspondents sub-index is made up of nine indicators defining regulations that answer four sets of questions: (a) who qualify as correspondents and what can correspondents do? (b) who is accountable for the activities of correspondents and how can this accountability be enforced? (c) how do they deal with the issue of exclusivity, namely the right of a correspondent to be associated with only one financial institution? and (d) is there any role for the regulation of fees and commissions associated with the operation of correspondents?

The first question is answered through the usage of five indicators. Improving financial inclusion requires the existence of clearly drafted regulation allowing financial institutions to engage the services of correspondents. Allowed institutions should include all types of regulated financial services providers (regulatory framework indicator). Constraints on the types of establishments that can act as correspondents should be kept to the minimum allowed by safety considerations; with the possibility of financial institutions contracting the services of a network administrator that manages and operates networks of correspondents (business model indicator). ${ }^{37}$ Moreover, the range of permitted financial service activities conducted by

\footnotetext{
36: The key difference with respect to other delivery channels such as financial institutions' branches, kiosks or ATMs is that, in the correspondents' business model, financial services are provided by the employees of the commercial establishment itself, not by the financial institution's employees or machines

37: To guarantee networks of agents able to provide professional customer services, manage liquidity and keep records, national regulations sometimes include restrictions to the legal form of the agents. For instance, some countries limit agents to legal persons, explicitly exclude those institutions whose activity is the provision of
} 
correspondents should be commensurable to the potential risks to the consumer and to the stability of the financial system. In this regard, while the provision of transactional services by correspondents is encouraged, the engagement of these agents in credit activities needs to be limited to transmitting the necessary documentation related to a loan application to the financial institution (permitted activities indicator). To avoid unnecessary regulatory obstruction, the regulation should allow financial institutions to set their own limits to the volume or balance of operations performed by correspondents, but these limits should be made public (transactional limits indicator). Finally, to protect consumers, the regulations need to require that the security and confidentiality of clients' information is guaranteed, that transactions take place in real time and through electronic systems connected to the central system of the financial institution, that clients receive records of transactions and that correspondents receive adequate training to serve customers (operational requirements indicator).

The accountability and supervision indicators address the second question. The financial institution (the principal) should be liable for the activities of its correspondents (the agents). By forcing providers to ensure the observance of legislative provisions by the agents, many regulatory concerns about the use of agents are alleviated, allowing regulators to design a more flexible legal framework in terms of the legal form of the agent or the services they may offer. ${ }^{38}$ In this regard, the role of supervisors is to assess the qualifications of financial institutions to engage correspondents and, when appropriate, authorise the use of these agents; but supervisors should not be involved in the authorisation of each new agency contract. Supervisors should also be able to conduct onsite and offsite inspection of correspondents' activities and request information and documentation when deemed necessary while avoiding excessive requirements that might hinder the provision of financial services to low-income populations.

To deal with the issue of agent exclusivity, the interoperability and exclusivity indicator measures whether regulators support but do not mandate interoperability, namely, the capacity of a correspondent to serve customers from several financial institutions. The issue here is that financial institutions first entering into the business of engaging correspondents need to have adequate incentives to invest in a network of agents. However, as the market deepens and agent networks expands, agent exclusivity becomes an issue of competition policy. Thus, the recommendation is for the regulation to permit exclusivity, at least in the initial stages of development, but ensure that the infrastructure used by correspondents to deliver financial services has the capacity to become interoperable at a later stage as markets develop.

Finally, the fees and commissions indicator follows the same principle used in the Simplified Accounts and Electronic Money sub-indices; that is, absent monopoly powers, regulation should impose no restrictions on the fees set by financial institutions to be charged to customers. In

financial services or prohibit non-for-profit institutions from acting as agents. However, as recognised by CGAP (2011a), CAF (2013a) and CNBV (2011), this may run counter to financial inclusion goals by unintentionally restricting the involvement of actors who could be the most promising agents. Evidence from several countries suggests that when the selection of micro-entrepreneurs and SMEs as agents is permitted, reaching rural areas becomes more feasible.

38: On this point, see CGAP (2011a) 
the presence of uncompetitive behaviour, however, regulatory intervention is warranted to prevent excessively high pricing. ${ }^{39}$ An additional component of this indicator is that, for consumer protection, regulation should not allow correspondents to charge extra fees and commissions to clients. Also, no regulatory restrictions should be established on the compensation paid by financial institutions to correspondents.

The scoring methodology for these indicators and the weighting system used to obtain the overall scores for the Correspondents sub-index is presented in Annex I.E.

The main sources of information used in the scoring of each country are national legislation and the additional sources listed in the Reference Section.

Table 7 presents results for the sub-index of Correspondents in Latin American countries. Annex X summarises the major characteristics of individual indicators in each country.

\footnotetext{
39: As in the case of Simplified Accounts and Electronic Money, we have taken this consideration into account by constructing an adjusted fees and commission indicator, which takes into account the value of the Competition Policies sub-index
} 
Table 7: The Sub-Index of Correspondents in Selected Latin American countries.

The Scores

\begin{tabular}{|c|c|c|c|c|c|c|c|c|}
\hline Criteria/ Country & Argentina & Brazil & Chile & Colombia & Mexico & Paraguay & Peru & Uruguay \\
\hline 1 Regulatory framework & 0 & 2 & 1 (b) & 2 & 2 & 1 & 2 & 2 \\
\hline 2 Accountability & n.a. & 2 & 2 & 2 & 2 & 2 & 2 & 2 \\
\hline 3 Business models & n.a. & 2 & 1.5 & 2 & 2 & 1.5 & 2 & 2 \\
\hline 3.A. Types of establishments & -- & 2 & 2 & 2 & 2 & 1 & 2 & 2 \\
\hline $\begin{array}{l}\text { 3.B. Management of the } \\
\text { network }\end{array}$ & -- & 2 & 1 & 2 & 2 & 2 & 2 & 2 \\
\hline 4 Permitted activities & n.a. & 2 & 1 (c) & 2 & 1.3 & 2 & 2 & 1.7 \\
\hline 4.A. Transactions & -- & 2 & 2 & 2 & 2 & 2 & 2 & 2 \\
\hline 4.B. Credit & -- & 2 & 1 & 2 & 0 & 2 & 2 & 2 \\
\hline 4.C. Affiliation of clients & -- & 2 & 0 & 2 & 2 & 2 & 2 & 1 \\
\hline 5 Transactional limits & n.a. & 1 & 2 & 2 & 1 & 2 & 2 & 2 \\
\hline 6 Operational requirements & n.a. & 1 & 1 & 1.8 & 2 & 1.8 & 1 & 1.5 \\
\hline 6.A. Security of the information & -- & 2 & 2 & 2 & 2 & 2 & 2 & 2 \\
\hline $\begin{array}{l}\text { 6.B. Training and capacity- } \\
\text { building }\end{array}$ & -- & 2 & 2 & 2 & 2 & 2 & 2 & 2 \\
\hline 6.C. Records of transactions & -- & 0 & 0 & 2 & 2 & 2 & 0 & 0 \\
\hline 6.D. On-line operations & -- & 0 & 0 & 1 & 2 & 1 & 0 & 2 \\
\hline 7 Supervision & n.a. & 1 & 1 & 2 & 1 & 2 & 2 & 1 \\
\hline 7.A. Authorisation & -- & 0 & 0 & 2 & 1 & 2 & 2 & 0 \\
\hline 7.B. Supervision & -- & 2 & 2 & 2 & 1 & 2 & 2 & 2 \\
\hline $\begin{array}{l}8 \begin{array}{l}\text { Interoperability and } \\
\text { exclusivity }\end{array} \\
\end{array}$ & n.a. & 1 & 1 & 2 & 2 & 2 & 2 & 0 \\
\hline 9 Fees and commissions & n.a. & 0 & 0.8 & 2 & 2 & 2 & 2 & 2 \\
\hline $\begin{array}{l}\text { 9.A. Compensation and fees } \\
\text { paid to correspondents }\end{array}$ & -- & 0 & 2 & 2 & 2 & 2 & 2 & 2 \\
\hline $\begin{array}{l}\text { 9.B. Fees and commissions } \\
\text { charged to clients } \\
\text { 9.BA. Adjusted fees and }\end{array}$ & -- & 0 & 0 & 2 & 2 & 2 & 2 & 2 \\
\hline $\begin{array}{l}\text { commissions paid to clients } \\
\text { (for quality of competition } \\
\text { policies) }\end{array}$ & -- & 0 & 0 & 2 & 2 & 2 & 2 & 2 \\
\hline $\begin{array}{l}\text { Correspondents Sub-Index } \\
\text { Score }\end{array}$ & 0 (a) & 1.3 & 1.3 & 1.97 & 1.7 & 1.8 & 1.9 & 1.6 \\
\hline
\end{tabular}

n.a.: not applicable.

(a) There is no regulatory framework for agents in place in Argentina

(b) The figure of agent or correspondent in Chile has not been formally defined or incorporated in the Chilean legal framework. However, banking institutions are allowed to outsource some services through establishments known as "proveedores de servicios externos" (which include providers of a variety of services—such as administrative 
support or hiring of personnel—and not just financial services). No additional regulation has been identified that applies to financial institutions other than banks

(c) Regulation does not provide an explicit list of financial products or services to be offered through correspondents, but states that the contract should address the definition of those activities to be outsourced. For instance, the network of correspondents of the public bank BancoEstado (Caja Vecina), provides the following activities: bill and utilities payments, payments of credits, cash deposits and withdrawals and transfers, according to CAF (2013b).

With a score of 1.97, Colombia almost gets the highest possible score as there are no significant regulatory impediments to the adequate operation of correspondents. ${ }^{40}$ Paraguay and Peru also get very high scores (1.8 and 1.9). In Paraguay, necessary improvement to reach the top score include extending the correspondents regulatory framework to financial institutions other than banks (such as credit cooperatives), permission for small financial institutions to act as correspondents for larger financial firms and a better balance in some operational requirements to give financial institutions sufficient freedom to define their models. In Peru, better clarity in the regulatory framework may be needed, for instance as regards the need of records of transactions to be delivered to clients or the conduct of operations on line.

At 1.7 and 1.6 Mexico and Uruguay's scores are in the middle of the countries in our sample (excluding Argentina), although regulation has been improving over the last years. For instance, at the inception of the correspondents in Mexico, the regulation applied only to banks. However, the 2014 Financial Sector Reform opened this possibility to entities in the Popular Credit and Savings Systems (Socaps and Sofipos) with the aim of facilitating the expansion of a sector which already catered to 7 million people, mainly in rural and semi urban areas (ElEconomista, 2013). Remaining areas for improvement include allowing correspondents to receive (from the public) and send (to the financial institution) the necessary information and documentation to obtain credit; as well as simplifying the supervisory processes for authorising and overseeing the operation of correspondents. Uruguay is the only country in the sample where agents' interoperability is mandated (financial institutions are prohibited from signing exclusivity arrangements with correspondents) and supervisors need to authorise each correspondent contracted by financial institutions.

Lower scores (1.3) have been obtained by Brazil and Chile. Although Brazil is among the world leaders in the usage of correspondents for advancing financial inclusion, there are some areas where improvements are called for. In particular, there is excessive government intervention in the setting of fees charged by financial institutions to clients for the services offered through correspondents and insufficient clarity regarding agents' interoperability. ${ }^{41}$

\footnotetext{
40: Lack of explicit regulatory authorisation for certain transactions with no risk of fraud to be conducted off-line prevents Colombia from achieving an overall score of 2.

${ }^{41}$ : In addition, contrary to best practices, financial institutions in Brazil do not require any type of authorisation to operate through correspondents' networks. This is also the case in Chile. As mentioned above, the authorisation process needs to establish that financial institutions have the capability to engage correspondents.
} 
In Chile, the regulation does not explicitly impede correspondents from charging additional fees to the contracting financial institution's clients. In addition, the regulation is silent regarding interoperability issues and there are some shortcomings in operational requirements. For example, there are no requirements for operations to be conducted online, even in the case of transactions with risk of fraud due to multiple withdrawals, and the regulation does not deal with the need to handle records of transactions.

In Argentina, there is no regulatory framework for agents in place, although CGAP (2010) reported that the Central Bank was in the process of drafting a regulation on the issue. However, this regulation has not materialised and no further communications from the BCRA on the issue have been issued. Furthermore, Cámara et al. (2015), which collected data on agents in over 70 economies, report that the number of active correspondents in Argentina is zero.

\section{d. Promoter 4: Microcredit}

Microfinance refers to the provision of formal financial services to poor and low-income population, as well as others excluded from the financial system. The term microfinance, however, covers a wide range of credit products (for business purposes, for consumptionsmoothing, for emergencies), savings, insurance, money transfers, etc. Focusing on microcredit, the literature identifies the following defining features: (i) it is a loan of smaller volume than traditional bank loans, (ii) it is not backed by conventional collateral pledges, (iii) the borrower is usually self-employed or informally employed and (iv) the lender follows a microlending methodology different from traditional lending methodologies. ${ }^{42}$ However, regulatory definitions for microcredit might differ for individual countries and should not be simply drawn from the literature. The best-suited regulatory definition in each country will depend on the specific objectives the regulation is meant to serve.

To assess the adequacy of a country's regulation on the provision of microcredit, the Microcredit sub-index is made up of four indicators reflecting the distinctive features of this financial service. The first indicator deals with overarching characteristics of the regulatory framework for microcredit; the last three focus on legal rules to govern and oversee the provision of microcredit products. These rules cover the areas of prudential regulation, nonprudential regulation and the supervisory framework.

Acknowledging that the particular features of microcredit give rise to different risks from those arising from traditional credit products, the indicator on regulatory framework calls for a formal definition and a differentiated regulatory treatment from that applied to traditional lending activities. The absence of a dedicated regulatory framework for microcredit could limit its potential development, since institutions engaged in this activity might be forced to comply with traditional financial regulations which are not suited to the particularities of the microlending activity or it might lead to abusive practices leading to over-indebtedness of the borrowers ${ }^{43}$ In building a differentiated regulatory framework, regulators should seek to

42: See CGAP (2012).

43: See Planet Finance (2011). 
create a level playing field in the microcredit market. This means that regulations should be the same for functionally similar services, regardless of the type of provider offering them, as long as they pose similar risks. ${ }^{44}$

While there is wide consensus on the need for this differentiated regulatory approach, experts and policy makers have not yet reached an agreement on how to build it. In fact, there is significant heterogeneity in the regulation governing the practice of microcredit across jurisdictions. However, over recent years, international institutions and standard setters have aimed at identifying best practices (CGAP, 2012; BCBS, 2010, 2016) which deal with the dual objective of achieving the traditional regulatory goals associated with the provision of financial services (namely, financial stability, financial integrity and consumer protection) and facilitating access to credit and promoting financial inclusion. These best practices have served as the basis for the construction of the indicators on prudential regulation, non-prudential regulation and the supervisory framework.

Generally speaking, prudential regulation aims at protecting the financial system from the risks of failure of one or several financial institutions, as well as protecting small depositors who lack the resources or capacity to monitor the institutions' behaviour and soundness themselves. In the case of microcredit, sound prudential regulation and, accordingly, our prudential regulation indicator seeks to ensure that the regulatory framework for risk management of microcredit portfolios is comprehensive, differentiated from those imposed on traditional credit portfolios, and includes rules on portfolio classification, provision and collateral. At the same time, the size of the loans and the nature of the borrowers justify lighter documentation requirements for microcredit than for conventional retail loans. ${ }^{45}$

The indicator on non-prudential regulation acknowledges the particular importance of appropriate financial consumer protection to low income population as these customers usually lack sufficient financial education and experience with formal financial services. Moreover, the indicator assesses whether microcredit providers disclose complete information about services offered, with an emphasis on the simplicity, accuracy and clarity of the information released. These regulatory requirements should apply equally to every microcredit provider.

Finally, the indicator on microcredit supervision assesses whether supervisory authorities have sufficient capacity to oversee microcredit institutions. Due to the distinctive features that characterise microcredit, its supervision demands specialised skills, procedures and tools that differ substantially from the ones used for conventional retail banking portfolios.

The scoring methodology for these indicators and the weighting system used to obtain the overall scores for the Microcredit sub-index is presented in Annex I.F.

\footnotetext{
44: As discussed throughout this document, a regulatory framework that sets a level playing field applied to all type of financial services and products (see Claessens and Rojas-Suarez, 2016)

45: See Annex I.F. for further detail on other prudential requirements for microcredit that might also need to be differentiated from traditional credit activities.
} 
The main sources of information used in the score for each country are national legislation for the scores on indicators related to regulation and the Global Microscope (2013 and 2016) for the indicator on microcredit supervision. Additional sources are listed in the Reference Section.

Table 8 presents results for the sub-index of Microcredit in Latin American countries. Annex $\mathrm{XI}$ summarises the major characteristics of individual indicators in each country.

Table 8: The Sub-Index of Microcredit in Selected Latin American countries: The Scores

\begin{tabular}{|c|c|c|c|c|c|c|c|c|c|}
\hline \multicolumn{2}{|c|}{ Criteria/ Country } & \multirow{2}{*}{$\begin{array}{c}\text { Argentina } \\
1\end{array}$} & \multirow{2}{*}{$\begin{array}{c}\text { Brazil } \\
2\end{array}$} & \multirow{2}{*}{$\begin{array}{c}\text { Chile } \\
1\end{array}$} & \multirow{2}{*}{$\begin{array}{c}\text { Colombia } \\
2\end{array}$} & \multirow{2}{*}{$\begin{array}{c}\text { Mexico } \\
1\end{array}$} & \multirow{2}{*}{$\begin{array}{c}\text { Paraguay } \\
1\end{array}$} & \multirow{2}{*}{$\begin{array}{c}\text { Peru } \\
2\end{array}$} & \multirow{2}{*}{$\begin{array}{c}\text { Uruguay } \\
1\end{array}$} \\
\hline 1 & Regulatory framework & & & & & & & & \\
\hline & 1A Regulatory definition & 2 & 2 & 0 & 2 & 2 & 2 & 2 & 0 \\
\hline & 1B Functional Approach & 0 & 2 & 2 & 2 & 0 & 0 & 2 & 2 \\
\hline \multirow[t]{3}{*}{2} & Prudential regulation & 1 & 0.5 & 0 & 1 & 1 & 1.5 & 2 & 0 \\
\hline & $\begin{array}{l}\text { 2A Regulatory framework } \\
\text { for risk management }\end{array}$ & 0 & 1 & 0 & 2 & 2 & 1 & 2 & 0 \\
\hline & $\begin{array}{l}\text { 2B Loan documentation } \\
\text { requirements }\end{array}$ & 2 & 0 & 0 & 0 & 0 & 2 & 2 & 0 \\
\hline \multirow[t]{3}{*}{3} & Microcredit supervision & 1.5 & 1 & 1.5 & 1.5 & 1.5 & 1.3 & 1.8 & 1.5 \\
\hline & $\begin{array}{l}\text { 3A Institutional framework } \\
\text { for microcredit } \\
\text { supervision }\end{array}$ & 1 & 1 & 1 & 1 & 1 & 1.5 & 1.5 & 1 \\
\hline & $\begin{array}{l}\text { 3B Supervision procedures } \\
\text { for microcredit }\end{array}$ & 2 & 1 & 2 & 2 & 2 & 1 & 2 & 2 \\
\hline \multirow[t]{3}{*}{4} & Non-prudential reg. & 0.8 & 1.3 & 1.8 & 2 & 1.5 & 0.3 & 2 & 1.3 \\
\hline & 4A Consumer protection & 1 & 2 & 2 & 2 & 1 & 0 & 2 & 2 \\
\hline & $\begin{array}{l}\text { 4B Disclosure and } \\
\text { transparency }\end{array}$ & 0.5 & 0.5 & 1.5 & 2 & 2 & 0.5 & 2 & 0.5 \\
\hline \multicolumn{2}{|r|}{ Microcredit Sub-Index Score } & 1.1 & 1.2 & 1.1 & 1.6 & 1.3 & 1 & 1.9 & 1 \\
\hline
\end{tabular}

Peru and Colombia (with overall scores of 1.9 and 1.6 respectively) attain the best positions among countries in the sample. Both countries got the highest possible scores in the indicators on regulatory framework and non-prudential regulation. There are, however, some significant differences between these two countries. For example, while Peru receives a perfect score in the indicator on prudential regulation, in Colombia this indicator receives a low value because of insufficient regulatory clarity for the documentation requirements needed to obtain microloans. ${ }^{46}$

\footnotetext{
46: For instance, improved clarity could be achieved by explicitly incorporating microcredit to the categories of financial products that can be subject to simplified KYC rules.
} 
Argentina, Brazil, Chile and Mexico are in intermediate positions with scores of 1.3 (Mexico), 1.2 (Brazil) and 1.1 (Argentina and Chile). The areas where the need for improvement is greatest, however, vary between these countries. In Mexico, the regulatory framework could benefit for a harmonized microcredit definition for all sectors allowed to offer it. Also, prudential regulations require amendments to incorporate differentiated loan documentation requirements. In Argentina, non-prudential regulations, especially in the area of disclosure and transparency, are not strong enough since not all microcredit providers (in this case those that are not regulated by the Central Bank) are required to give clear and complete information about the services offered to their clients. One of Brazil's weak areas is that of microcredit supervision. According to the EIU Global Microscope (2016), remote supervision is conducted through reporting requirements that are reasonable for banks but not tailored to microenterprise credit societies, which face essentially the same reporting requirements as banks. In Chile, prudential regulations require amendments, especially since there is no differentiated regulatory framework for risk management of microcredit portfolios.

The lowest overall scores are obtained by Paraguay and Uruguay (with scores of 1). Uruguay (together with Chile) stands out as the country in the sample that does not incorporate a definition of microcredit in the regulation; as a consequence, this country also lacks a regulatory framework for risk management of microcredit portfolios. Among the countries in the sample, Paraguay receives the lowest score in non-prudential regulation (0.3). This is because regulations on consumer protection are not uniform for banks, finance companies and cooperatives. As reported by the World Bank (2014), there is evidence of abusive collection practices for past due loans in the case of non-regulated institutions.

\section{e. Promoter 5: Credit Reporting Systems}

Insufficient information about borrowers is a key obstacle for the adequate provision of credit to large segments of the population. Without comprehensive and updated information on borrowers, lenders face significant trouble in evaluating borrowers' creditworthiness accurately. Asymmetry of information between lenders and borrowers can lead to significant misallocation of credit, where some borrowers accumulate debt beyond their repayment capacity (over-indebtedness), while others, with viable and profitable projects, are excluded from access to credit.

Credit reporting systems address the problem of the asymmetry of information in credit markets. Available empirical analysis suggests that the development of credit reporting systems, both public and private, has an influence on the development of the financial sector, financial stability and access to credit. ${ }^{47}$ Critically important, availability of comprehensive information on borrowers provides those at the base-of-the-pyramid with

47: This relationship is more pronounced for economies with a less developed financial sector. See IADB (2005) and World Bank (2016b). 
"reputational collateral", a potentially highly valuable asset arising from a positive credit history. 48

Credit reporting systems are formed by credit bureaus and credit registries. While in some countries, these terms are used interchangeably, here we follow the World Bank Doing Business Reports and define a credit bureau as a private firm or non-profit organisation that maintains a database on the creditworthiness of borrowers (individuals or firms) in the financial system and facilitates the exchange of credit information among creditors. A credit registry is defined as a database managed by the public sector, usually by the central bank or the superintendent of banks, which collects information on the creditworthiness of borrowers (individuals or firms) in the financial system and facilitates the exchange of credit information among banks and other regulated financial institutions.

The Credit Reporting Systems sub-index measures those rules that define the coverage, quality, accessibility and safety of credit information available either through a credit bureau, a credit registry, or both. It is made up of two indicators. The first indicator, comprehensiveness of information, assesses whether the credit reporting system needs to gather detailed information about firms and individuals, including positive and negative information about their repayment history, and whether this information is obtained from as many sources as possible and covers observations from a sufficient period of time.

The second indicator, accessibility and safety evaluates the soundness of the system, which should strike a balance between the goal of providing sufficient access to the information covered and the desire to preserve individual privacy. This refers to the rules governing the process of information-sharing, the lenders' ability to use data on borrowers to assess their creditworthiness and the extent to which privacy rights exist and are observed. Although there is no clear consensus on what the optimal framework for credit reporting systems might be, the World Bank (2011a) acknowledges that there is a clear trend worldwide towards ensuring that individuals are able to access and correct the information being kept about them.

The variables used in the construction of the two indicators follows closely the definitions used in the depth of credit information index in the World Bank Doing Business reports. The scoring methodology for these indicators and the weighting system used to obtain the overall scores for the Credit Reporting Systems sub-index is presented in Annex I.G.

The main sources of information used in the score of each country are national legislation and the additional sources listed in the Reference Section.

Table 9 presents results for the sub-index of Credit Reporting Systems in Latin American countries. Annex XII summarises the major regulatory characteristics of individual in each country.

48: See CGAP (2011b) 
Table 9: The Sub-Index of Credit Reporting Systems in Selected Latin American countries. The Scores

\begin{tabular}{l|c|c|c|c|c|c|c|c}
\hline $\begin{array}{l}\text { Criteria / Country } \\
\mathbf{1} \quad \text { Comprehensiveness } \\
\text { of information }\end{array}$ & $\mathbf{2}$ & $\mathbf{1 . 5}$ & $\mathbf{0 . 5}$ & $\mathbf{2}$ & $\mathbf{2}$ & $\mathbf{1}$ & $\mathbf{2}$ & $\mathbf{2}$ \\
$\begin{array}{l}\text { 1A Sources of } \\
\text { information }\end{array}$ & 2 & 2 & 1 & 2 & 2 & 0.5 & 2 & 2 \\
$\begin{array}{l}\text { 1B Nature of the } \\
\text { information }\end{array}$ & 2 & 0.5 & 0.5 & 2 & 2 & 0.5 & 2 & 2 \\
$\begin{array}{l}\text { 1C Borrowers covered } \\
\text { Accessibility and }\end{array}$ & 2 & 2 & 0 & 2 & 2 & 2 & 2 & 2 \\
\hline $\begin{array}{l}\text { safety } \\
\text { 2A Borrowers' access }\end{array}$ & 2 & 1 & 2 & 2 & 2 & 1 & 2 & 2 \\
2B Lenders' access & 2 & 2 & 2 & 2 & 2 & 2 & 2 & 2 \\
2C Data protection & 2 & 2 & 2 & 2 & 2 & 2 & 2 & 2 \\
$\begin{array}{l}\text { Credit Reporting } \\
\text { Systems Sub-Index } \\
\text { Score }\end{array}$ & $\mathbf{2}$ & $\mathbf{1 . 6}$ & $\mathbf{1 . 3}$ & $\mathbf{2}$ & $\mathbf{2}$ & $\mathbf{1 . 4}$ & $\mathbf{2}$ & $\mathbf{2}$
\end{tabular}

Among all the sub-indices discussed in this paper, Credit Reporting Systems is notable for the high scores in most of the countries. For example, Argentina, Colombia, Mexico, Peru and Uruguay obtain the maximum score. In these four countries, the regulatory frameworks for credit registries and bureaus are well designed in terms of the breadth, quality and security of information collected and provided to customers, allow for large coverage of borrowers, especially small and micro enterprises, and are, therefore, supportive of financial inclusion.

In Brazil, the most important shortcoming identified is that there are deficiencies in certain legislation that prevents private credit bureaus from collecting positive information about borrowers. As reported by the World Bank Doing Business Report (2017) and market participants, the request of having the explicit authorisation of customers to participate in the positive bureau (Cadastro Positivo) is hindering its development. ${ }^{49}$

In Paraguay, a score of 1.4 reflects that private credit bureaus are only allowed to gather negative information (the public register covers positive information, but only from banks) and deficiencies in terms of the scope of information. In addition, the legislation does not set out clear rules on how individuals can correct erroneous information in their credit information.

Chile is the country in the sample with the lowest score (1.3) and this is largely the result of deficiencies in legislation regarding the comprehensiveness of information: Private credit

49: The Central Bank of Brazil and the Brazilian Government have recognised this problem and presented a legal proposal to its solution. However, the proposal has not yet been adopted as of April 2017. 
bureaus are only allowed to gather negative information and are not allowed to collect information from utility companies. In addition, the law does not permit the disclosure of information of low-value loans; thus, micro enterprises are adversely affected. Due to these inadequacies, private bureaus' coverage only reaches 12.4 percent of the adult population, according to data provided by the World Bank.

\section{f. Promoter 6: Simplified KYC requirements}

Financial integrity is, together with financial stability and consumer protection, an essential objective for financial regulators. Recommendations by the Financial Action Task Force (FATF), ${ }^{50}$ although not legally binding at the national level, are recognised as the global standards for anti-money laundering (AML) and combating the financing of terrorism (CFT) (FATF, 2012, 2013).

An essential element of the AML/CFT framework are the rules that guarantee that financial institutions know the identity of the parties they engage with. These rules are referred to as know-your-customer rules (KYC rules), and basically deal with how financial services providers exercise due diligence in establishing the identity of their users (hereinafter customer due diligence or CDD). A system in which clients are not correctly identified and therefore allowed total anonymity is vulnerable to the risks of money laundering and the financing of terrorism. Thus, sound KYC rules are essential to ensure financial integrity.

However, the proper design of KYC, and more generally, the AML/CFT rules is not only important to guarantee the integrity of the financial system, but also to permit financial institutions to be willing to extend the full range of their financial products and services to a client, and, therefore, for financial inclusion. The impact of AML/CFT rules on the financial inclusion of economically and socially vulnerable people has been under discussion for years. For instance, research supported by the World Bank and the CGAP has concluded that AML/CFT regulations if not adequately calibrated can negatively affect access to, and usage of, financial services. ${ }^{51}$ Ultimately, financial inclusion and the integrity of the financial system are not only complementary but mutually reinforcing policy objectives. The financial services and transactions of financially-excluded people are pushed out of the regulated system, into an underground economy where transactions lack visibility and are thus difficult for the authorities to monitor, thus undermining AML/CFT measures (FATF, 2013).

Therefore, the challenge is to design international standards and national rules that guarantee the integrity of the financial system without hindering financial inclusion efforts, and ideally promoting them. This principle is shared by governments and policy-makers globally, and is recognised in the latest amendments to the FATF recommendations (FATF, 2012) that explicitly acknowledge the need for a risk-based approach that carefully balances both policy

\footnotetext{
50: FATF is the international body mandated by the G20 with the development and promotion of policies to protect the global financial system against the risks of money laundering and the financing of terrorism 51: See for instance: Bester, H., et al (2008), and De Koker, L. (2006).
} 
objectives. ${ }^{52}$ Generally speaking, a risk-based approach to KYC is based on the principle of proportionality: KYC rules need to reflect the reality and risks of different types of customers (Claessens and Rojas-Suárez, 2016; FATF, 2013). Acknowledging this fact, FATF allows exemptions from AML/CFT obligations in proven low-risks scenarios, which translate in the use of simplified CDD measures in such cases. This tiered approach to KYC allows regulators to distinguish between customers and transactions that pose higher or lower risks, and thus leads to practices that are effective, efficient and not too onerous for providers and regulators to apply.

The Simplified KYC Requirements sub-index assesses the extent to which the principle of proportionality is incorporated in countries' KYC rules and whether these rules are similarly applicable to alternative providers of financial services. It is made up of four indicators. The first indicator deals with the issue of creating a level playing field among providers. The last three deal with the adequate usage of simplified CDD procedures for low-income customers.

The indicator on level playing field evaluates whether KYC rules favour a particular set of financial service providers. That is, the rules should be equivalent for all alternative providers, including banks, other traditional financial institutions, providers of electronic money and other digital services providers (DSPs).

The rest of the indicators seek to determine whether a proportional, risk-based approach is applied to the entire procedure of (a) identifying the customer, (b) verifying his/her identity and (c) recording such information as prescribed by the law for a minimum period of 5 years according to the FATF Guidance. Under a tiered KYC requirement, customers' identification requirements for low-risk customers should only consist of basic information that is readily accessible for the low-income population, such as name, date of birth and national identification number.

Verification requirements poses important challenges for financial inclusion. While the reliable verification of customers' identity usually depends on strong customer identification credentials, in many countries the legal system for identification is weak or non-existent, making it impossible for financial institutions to verify an identity and thus undermining financial inclusion efforts (Gelb, 2016). Adequate verification requirements for low-income customers imply that national legislation clearly identifies the documents required to verify customers' identity. If the national ID system is weak or hard to access for low-income population, countries need to expand the range of acceptable identification means. ${ }^{53}$

Finally, the indicator on record-keeping requirements calls for countries to avoid excessively onerous procedures for keeping records on identification documents (such as creating hardcopies of photos and applications forms). Instead, these requirements need to be streamlined for low-income customers, especially since these customers are often served by

\footnotetext{
52: Additional guidance was provided by the FATF in 2013 with the goal of assisting jurisdiction in the implementation of an AML/CFT framework that is consistent with the goal of financial inclusion.

53: This has been acknowledged by the FATF Guidance (FATF, 2013).
} 
networks of agents formed by small shops that cannot afford the cost of getting and utilizing a printer or a camera-enabled phone. ${ }^{54}$ Other forms of record keeping contemplated by the FATF Guidance (2013), such as keeping electronic copies or merely recording reference details, can help to improve the business case of serving customers at the base of the pyramid.

The scoring methodology for these indicators is presented in Annex I.H. The main sources of information used in the scoring of each country are national legislation. Additional sources are listed in the Reference Section.

A point of clarification deserves attention. Due to insufficient guidance from standardsetting bodies, the Simplified KYC Requirements sub-index does not assess the quality of the enforcement framework for KYC rules. In particular, there is no proper guidance for identifying the degree of severity of violations of KYC rules and what the relevant sanctions should be. Ex ante clarity is needed on the severity of offenses and the amount of the penalties; otherwise, financial institutions will respond as if all infringements carry a very high penalty. This will reduce their incentives to engage with many clients, but especially with small, low-income clients, from whom the provider already expects relatively small profit (Claessens and Rojas-Suárez, 2016). Thus, this important component of a sound riskbased approach is needed to avoid financial institutions "de-risking" from entire categories of clients. ${ }^{55} 56$

Lacking these specific guidelines, we do not incorporate an indicator to assess the quality of the enforcement framework for KYC rules. This is, unfortunately, an important shortcoming for the construction of and interpretation of results from the sub-index of Simplified KYC Requirements.

Table 10 presents results for the sub-index of KYC Requirements in Latin American countries. Annex XIII summarises major characteristics of individual indicators in each country.

\footnotetext{
54: See Di Castri et.al. (2016)

55: However, regulators' enforcement practices have received relatively little attention from standard-setting bodies, compared with the principles financial institutions must comply with (McGough, 2016).

56: Following the risk-based, proportional approach, in the case of small-value accounts and limited transactions, penalties should be set depending on whether the financial institution responsible for complying with KYC requirements has failed to do so, and not based on whether how many violations have taken place. Furthermore, penalties should be set on a graduated basis and have a reasonable, ex ante defined upper limit, and should increase as the failure to comply becomes more serious and persistent (Claessens and Rojas-Suárez, 2016; McGough, 2016).
} 
Table 10: The Sub-Index of Simplified KYC Requirements in Selected Latin American countries. The Scores

\begin{tabular}{|c|c|c|c|c|c|c|c|c}
\hline Criteria / Country & Argentina & Brazil & Chile & Colombia & Mexico & Paraguay & Peru & Uruguay \\
\hline $\begin{array}{l}\text { Level playing field } \\
2\end{array}$ & 2 & 2 & 2 & 2 & 2 & 0 & 2 & 2 \\
$\begin{array}{l}\text { Identification } \\
\text { requirements }\end{array}$ & 2 & 1 & 2 & 2 & 2 & 1 & 2 & 2 \\
$3 \begin{array}{l}\text { Verification } \\
\text { requirements }\end{array}$ & 2 & 2 & 0 & 0 & 1.5 & 2 & 2 & 2 \\
$4 \begin{array}{l}\text { Record-keeping } \\
\text { requirements }\end{array}$ & 2 & 2 & 0 & 0 & 2 & 2 & 2 & 2 \\
\hline $\begin{array}{l}\text { Simplified KYC Sub- } \\
\text { Index Score }\end{array}$ & 2 & 1.8 & 1 & 1 & 1.9 & 1.3 & 2 & 2
\end{tabular}

Keeping in mind the important caveat regarding the lack of indicators for assessing the quality of the enforcement framework for KYC rules, the countries in our sample can be divided into two groups: those with the highest possible (Argentina, Peru and Uruguay) or a very high (Brazil and Mexico) score, and those with low scores (Chile, Colombia and Paraguay).

Colombia, with a score of 1 , loses points because the regulation is not clear about how financial institutions can verify the identity of customers. A case in point is regulation on simplified accounts: the rules state that financial institutions must have procedures in place to verify the content and veracity provided by customers, but it does not provide more clarity on how to do it. Moreover, the regulation contains excessively stringent recordkeeping requirements that impose the retention of physical copies of the documentation provided for the identification of clients for a minimum period of five years.

In Chile (with a score of 1), the regulation does not clearly define either the documents needed for a reliable verification of customers' identity or the record-keeping requirements. Finally, in Paraguay (with a score of 1.3), the simplified CDD procedures do not apply to cooperatives, which, as reported by the World Bank (2014) could facilitate the opening of accounts in rural areas. In addition, when applicable, simplified identity requirements for KYC are too restrictive since they include proof of income.

\section{g. A Non-Regulatory index: Financial Literacy}

As explained at the beginning of this section, policies to enhance financial literacy impact the outcome of all regulatory Promoters: regulations aimed at enhancing the offering and the use of financial products and services tailored to low income populations tend to have a higher probability of success in countries where authorities are more effective in designing and implementing policies for improving the financial education of these groups. To be more precise, in the context of financial inclusion, financial education facilitates access and encourages more widespread use of financial products and services by raising the awareness and understanding of such products. In fact, it is widely acknowledged that financial 
education helps reduce demand-side barriers to financial inclusion: it improves levels of financial literacy, can break down psychological barriers and raise awareness of innovations that can help reduce geographical barriers. ${ }^{57} 58$

Thus, here we construct an index assessing the quality of government efforts to improve Financial Literacy. This index is then used to adjust the scores in the Promoters index.

In constructing the index of Financial Literacy, we follow, to a large extent, the recommendations of the OECD/INFE High Level Principles on National Strategies for Financial Education, which contains valuable policy guidance to national regulators with a view to developing evidence-based, tailored approaches to financial education. ${ }^{59}$ Following these guidelines, the index of Financial Literacy is made up of two indicators.

The first indicator on financial education capacity assesses whether countries follow a nationally-coordinated approach that involves the cooperation of different stakeholdersfrom the public, private and non-for profit sectors, under the umbrella of a public institution with a clear mandate over financial education. Regarding the participation of the private financial sector, the OECD/INFE Principles highlight its importance as long as there is sufficient monitoring to prevent the emergence of conflicts of interest.

The second indicator on policy efforts evaluates whether financial education policies and strategies (a) include the identification of relevant target audiences and the timing of the delivery of this training, which preferably would take place at times when individuals are making long term plans or about to take important financial decisions, or when they are in an environment that is conducive to learning (school, college, workplace); (b) include a wide range of delivery and communication channels, tailored to the needs of the targeted audiences; and (c) are included in the design of welfare programmes such as the distribution of conditional transfers through simplified accounts.

The scoring methodology for these indicators and the weighting system used to obtain the score for the Financial Literacy index is presented in Annex I.I.

\footnotetext{
57: Financial education is defined as "the process by which financial consumers/investors improve their understanding of financial products, concepts and risks and, through information, instruction and/or objective advice, develop the skills and confidence to become more aware of financial risks and opportunities, to make informed choices, to know where to go for help, and to take other effective actions to improve their financial well-being" (OECD, 2005).

58: Over recent years, public institutions, international organisations and many national regulators have gained awareness of the need to foster financial literacy of individuals and households and to induce positive changes in their economic behaviour (introducing saving patterns, for instance). Policy makers now acknowledge the need to address the low financial literacy levels through financial education programmes and wider initiatives such as national strategies for financial education. (OECD, INFE, 2012; 2015).

59: According to García et al., (2012), there is no sufficient evidence to allow a thorough diagnosis of the needs and gaps in financial literacy within Latin America, complicating the process of identifying best practices, García et al. (2012) also signal that several policy programmes on financial literacy have been conducted in the absence of such evidence, leading to inefficient or ineffective outcomes.
} 
The main sources of information used in the scoring of each country are national legislation and the additional sources listed in the Reference Section.

Table 11 presents results for the index of Financial Literacy in Latin American countries. Annex XIV summarizes major characteristics of individual indicators in each country.

Table 11: The Financial Literacy Index in Selected Latin American Countries. The Scores

\begin{tabular}{|c|c|c|c|c|c|c|c|c|c|}
\hline \multicolumn{2}{|c|}{ Criteria / Country } & Argentina & Brazil & Chile & Colombia & Mexico & Paraguay & Peru & Uruguay \\
\hline \multirow[t]{3}{*}{1} & $\begin{array}{l}\text { Financial Education } \\
\text { Capacity }\end{array}$ & 0.5 & 2 & 1.3 & 1.3 & 1.3 & 0.5 & 2 & 0.5 \\
\hline & $\begin{array}{l}\text { 1A Institutional } \\
\text { Framework }\end{array}$ & 1 & 2 & 1.5 & $1.5(\mathrm{a})$ & 1.5 & 1 & 2 & 1 \\
\hline & 1B Coordination & 0 & 2 & 1 & 1 & 1 & 0 & 2 & 0 \\
\hline \multirow[t]{4}{*}{2} & Policy Efforts & 1.3 & 2 & 1.3 & 1.7 & 1.7 & 1.3 & 2 & 1 \\
\hline & 2A Target & 1 & 2 & 0 & 1 & 1 & 1 & 2 & 1 \\
\hline & $\begin{array}{l}\text { 2B Direct Access to } \\
\text { products }\end{array}$ & 2 & 2 & 2 & 2 & 2 & 2 & 2 & 0 \\
\hline & 2C Convenience & 1 & 2 & 2 & 2 & 2 & 1 & 2 & 2 \\
\hline \multicolumn{2}{|c|}{$\begin{array}{l}\text { Financial Literacy Index } \\
\text { Score }\end{array}$} & 0.9 & 2 & 1.3 & 1.5 & 1.5 & 0.9 & 2 & 0.8 \\
\hline
\end{tabular}

(a) In May 2017, the Intersectoral Commission on Economic and Financial Education issued for comments a National Economic and Financial Strategy. This Strategy, which is expected to be adopted in the coming months, will provide for a more coordinated, broad and robust response to financial education in Colombia, and may solve some outstanding issues, for instance as regards targeted audiences.

Countries can be grouped into three categories: high performers (Brazil and Peru); mediumlevel performers (Chile, Colombia and Mexico) and low performers (Argentina, Paraguay and Uruguay). Interestingly, countries in each category share similar strengths and weaknesses.

Brazil and Peru achieve the maximum score in the index and are the only two countries where there is a coordinated policy response among relevant authorities for promoting financial education. In Brazil, the National Strategy for Financial Education (ENEF, its Portuguese acronym) has been set under the responsibility of a Working Group coordinated by the Brazilian Securities and Exchange Commission. In Peru, the National Financial Inclusion Strategy (ENIF, its Spanish acronym) is oriented to financial education and jointly directed by the Superintendents of banking, insurance and pension funds and the Ministry of Education. Brazil and Peru are also the only two countries in the sample where the policies in place clearly identify target groups, and where coordination between the authorities and the private sector is also appropriate: private sector activities in this area are monitored to prevent conflicts of interest. 
Chile, Colombia and Mexico (with scores of 1.3, 1.5 and 1.5 respectively) share the same score (1.3) for the indicator Financial Education Capacity. In contrast to Brazil and Peru, in these three countries the participation of the private sector or financial service providers does not appear to be actively promoted (Chile) or monitored for the emergence of potential conflicts of interest (Colombia and Mexico). On the positive side, another similarity between these three countries is that they all get the top score in the component convenience since multiple channels are utilized for the provision of financial education. ${ }^{60}$

With an overall score of only 0.8 (Uruguay) or 0.9 (Argentina and Paraguay), the low performers share a number of weaknesses, but the absence of mechanisms for cooperation among relevant public authorities and between the public and private sector stands out. These three countries received a score of 0 in this component. Furthermore, financial education in these countries is mostly directed to the general population, despite being included in children and youth's education programmes. The lack of identification of specific target groups and the absence of consideration for the adequate timing to deliver financial education efforts reduces the effectiveness of these policies.

Ending on a positive note all the countries, with the exception of Uruguay, received the maximum score for the component of direct access to products. This means that financial education is incorporated in the design of welfare programmes, such as the distribution of conditional cash transfers. These programmes were identified in section IV.a within the discussion of the Promoter Simplified Accounts.

\section{The Promoters Index}

Table 12 shows the Promoters Index and its components. The value of the unadjusted index is the simple average of the scores obtained for the six sub-indices.

However, as discussed above, Financial Literacy affects the outcomes of all regulatory promoters. Therefore, we have created the Adjusted Promoters Index, which is also in the 0-2 range, and is dependent on the Financial Literacy sub-index score in the following way:

- If the Financial Literacy Sub-Index Score is lower than 1, then financial literacy policies are not strong and are unlikely to enhance the effectiveness of the regulatory Promoters. In this case, the score equals the Unadjusted Promoters Index.

- If the Financial Literacy Sub-Index Score is greater than 1 but lower than 1.7, a factor of 0.05 is added to the Unadjusted Promoters Index.

- If the Financial Literacy Sub-Index Score is greater than or equal to 1.7, a factor of 0.1 is added to the Unadjusted Promoters Index. ${ }^{61}$

\footnotetext{
60: See, Garcia et.al. (2012).

61: The maximum value that the Adjusted Promoted Index can take is 2 . Thus, if, after adding the score of the Unadjusted Promoters Index and that for Financial Literacy a country achieves a value greater than 2, the score of the Adjusted Promoted Index would be capped at 2. This issue did not appear in any of the countries in our sample; but could be an issue in future updates of this exercise.
} 
The adjustments are largely arbitrary; there are many different ways to generate the Adjusted Promoters Index and we certainly encourage researchers to propose alternative methodologies. In choosing the adjustment factors we have used two criteria. The first is simplicity. The second criterion aims to maintain the focus on regulations classified as Promoters; that is, we kept the adjustment factor at relatively low levels so that the adjusted score continued to reflect the strengths and weaknesses of the Promoters (rather than being obscured by the role of Financial Literacy).

Table 12: The Unadjusted and Adjusted Promoters Index in Selected Latin American Countries. The Scores

\begin{tabular}{|c|c|c|c|c|c|c|c|c|}
\hline Criteria / Country & Argentina & Brazil & Chile & Colombia & Mexico & Paraguay & Peru & Uruguay \\
\hline Simplified accounts & 1.5 & 0.8 & 1.4 & 1.7 & 1 & 0.9 & 1.1 & 0.9 \\
\hline E-money & 0 & 1.2 & 0.8 & 1.9 & $\mathbf{0}$ & 1.7 & 1.6 & 1.6 \\
\hline Correspondents & 0 & 1.3 & 1.3 & 2 & 1.7 & 1.8 & 1.9 & 1.6 \\
\hline Microcredit & 1.1 & 1.2 & 1.1 & 1.6 & 1.3 & 1 & 1.9 & 1 \\
\hline $\begin{array}{l}\text { Credit Reporting } \\
\text { Systems }\end{array}$ & 2 & 1.6 & 1.3 & 2 & 2 & 1.4 & 2 & 2 \\
\hline Simplified $K Y C$ & 2 & 1.8 & 1 & 1 & 1.9 & 1.3 & 2 & 2 \\
\hline $\begin{array}{l}\text { Unadjusted Promoters } \\
\text { Score }\end{array}$ & 1.1 & 1.3 & 1.2 & 1.7 & 1.3 & 1.4 & 1.8 & 1.5 \\
\hline Financial Literacy & 0.9 & 2 & 1.3 & 1.5 & 1.5 & 0.9 & 2 & 0.8 \\
\hline $\begin{array}{l}\text { Adjusted Promoters } \\
\text { Score (for Financial } \\
\text { Literacy) }\end{array}$ & 1.1 & 1.4 & 1.25 & 1.75 & 1.35 & 1.4 & 1.9 & 1.5 \\
\hline
\end{tabular}

With an adjusted score of 1.9, Peru achieved the highest score in the sample. The country's perfect (or almost perfect) scores in regulations supporting Credit Reporting Systems, Simplified KYC, Correspondents and Microcredit are the reasons for this outcome. The high-quality of its Financial Literacy policies further underpins the result. Colombia is relatively close behind, with an adjusted score of 1.75. In this case, its strongest areas of regulation are in E-money, Correspondents and Credit Reporting Systems.

In the rest of the countries, the adjusted scores reflect significant room for improvement. In Brazil, although the quality of its Financial Literacy policies is strong, most of the Promoters sub-indices achieve low values (with the exception of Simplified KYC and, to a certain extent, Credit Reporting Systems). In Mexico, top or very high scores in Credit Reporting Systems and Simplified KYC cannot offset the underperformance in some areas such as E-money. Mixed performance of Promoters is also a feature of Paraguay (high score in Correspondents but low ones in Simplified Accounts and Microcredit) and Uruguay (a perfect score in Simplified KYC and Credit Reporting Systems, and low scores in Microcredit and Simplified Accounts). By contrast, Chile did not achieve high scores in any of the Promoters. Financial Literacy policies also need to be upgraded in Chile, Mexico, Paraguay and Uruguay. 
Argentina gets the lowest adjusted score among the countries in the sample (1.1). In this case, there is a mix of Promoters with top scores (such as Credit Reporting Systems and Simplified KYC with a score of 2) and extremely weak ones (such as E-money and Correspondents with a score of 0). Efforts on Financial Literacy have a long way to go.

\section{Assessing Regulations Constraining Financial Inclusion: The Preventers}

This section ponders the three types of regulations classified as preventers in Table 1: transaction taxes, interest rate ceilings and directed lending. While there are certainly other regulatory practices acting as obstacles to financial inclusion, the three preventers discussed here are those most commonly used in Latin America. ${ }^{62}$ Regulations on know-your-customer, which can unintendedly deter the provision of financial services to the poor, are discussed in Section IV. The methodology for constructing the Preventers index and its three sub-indices is the same as that used in sections III and IV.

\section{a. Preventer 1: Financial Transaction Taxes}

Broadly speaking, there are several types of financial transaction taxes: bank debit taxes, bank credit taxes, securities transaction taxes and currency transaction taxes. This paper discusses only the first two categories of taxes given our focus on the direct effects on financial inclusion. ${ }^{63}$

Debit taxes have a long history in Latin America. Since the tax base is made up of bank deposits (and, sometimes, other bank liabilities) these taxes are easy to collect and, therefore, they were often initially imposed at times of severe economic and financial difficulties, when other forms of revenue collection have declined substantially (mostly during the 1990s). ${ }^{64}$ While reliance on these taxes has declined significantly in the region in the last decade, they are still in place in a number of countries, albeit with significant differences among the countries regarding the characteristics of the taxes.

In addition to other economic distortions generated by debit taxes, their adverse effects on financial inclusion are well known and have been discussed widely. ${ }^{65}$ Debit taxes create incentives for bank disintermediation and a move towards cash transactions and unregulated financial entities as individuals and firms attempt to avoid paying the taxes. Moreover, debit taxes could induce an increase in bank's interest rate spreads as banks respond to the profitability losses created by the disintermediation. All these effects impact small firms and the poor the most. In the case of small firms operating in the formal economy, their

\footnotetext{
62: See Rojas-Suarez (2007)

63: Taxes on securities and currency transactions might also have an indirect effect on financial inclusion to the extent that they affect financial intermediation.

64: For example, in Colombia, the tax was first implemented in 1998 to help finance the crisis resolution of mortgage institutions. In Peru, the tax was first introduced in 1989 as an emergency measure during the hyperinflation period.

65: See for example, Pecho Trigueros (2013) and Rojas-Suarez (2012).
} 
relatively limited resources prevent them from accessing off-shore markets and conducting operations with derivatives to avoid the tax, a privilege available to larger firms. In the case of individuals, higher transaction costs derived from a move towards cash operations and a larger reliance on informal financial markets run precisely against the central objective of financial inclusion; namely, increasing the proportion of the population undertaking financial transactions in the formal financial system.

As mentioned above, not all transaction taxes are designed equally in those Latin American countries that rely on them. Some are more pervasive than others as regards financial inclusion. Thus, in constructing the sub-index Financial Transaction Taxes, we took the following two considerations into account. The first is that countries where a transaction tax is applied to credit operations received the lowest possible score (zero to be precise), even if the tax does not affect debit operations. The reason for this is that, unless there are specific exceptions in the regulation, credit taxes penalise small businesses the most and provide incentives to obtain financing through the informal financial sector.

The second consideration is that rules and regulations might include some features that reduce the adverse effect of the debit tax on financial inclusion. Therefore, the indicator of financial transaction taxes is adjusted when one or more mitigating factors are in place (countries where mitigating factors are identified receive a higher score than countries where these factors have not been identified). Based on the Latin American experience, we have considered three mitigating factors: (a) bank customers have the opportunity to deduct or credit the tax against the payment of other taxes; (b) there are exemptions in the payment of the debit tax, when those exemptions are based on financial inclusion considerations; and (c) the debit tax is set at a rate close to zero; the only reason for keeping the tax is to provide bank customers with information from the country's Tax Authority for the purpose of collecting other taxes, such as income taxes.

The scoring methodology to calculate the unadjusted and adjusted (due to mitigating factors) indicators for financial transaction taxes are presented in Annex I.J. In this case, the overall score for the sub-index Financial Transaction Taxes is equal to the score for the adjusted indicator.

The information used to calculate countries' scores was mainly obtained from national tax authorities and from Pecho (2013). Additional sources are listed in the Reference Section.

Table 13 presents the Financial Transaction Taxes sub-index for our selected group of countries. A summary of the regulatory characteristics of each country is presented in Annex XV. Due to the complexity of the Brazilian case, Annex XVI presents a more detailed report on Brazil's regulations. 
Table 13: The Sub-Index of Financial Transaction Taxes in Selected Latin American Countries. The Scores

\begin{tabular}{l|c|c|c|c|c|c|c|c} 
Criteria / Country & Argentina & Brazil & Chile & Colombia & Mexico & Paraguay & Peru & Uruguay \\
\hline $\begin{array}{l}\text { Financial Transactions } \\
\text { Tax Score (unadjusted) } \\
\text { Mitigation Factors }\end{array}$ & $\mathbf{0}$ & $\mathbf{0 ~ ( a )}$ & $\mathbf{0}$ & $\mathbf{0}$ & $\mathbf{0}$ & $\mathbf{2}$ & $\mathbf{0}$ & $\mathbf{2}$ \\
$\begin{array}{l}\text { a. Adjustment for fiscal } \\
\text { deductions }\end{array}$ & -- & -- & -- & -- & 0.5 & n.a & 0.5 & n.a \\
$\begin{array}{l}\text { b. Adjustment for exceptions } \\
\text { in payment of tax (b) }\end{array}$ & 0.5 & -- & -- & 0.5 & 0.5 & n.a & -- & n.a \\
$\begin{array}{l}\text { c. Adjustment for close to } \\
\text { rero tax rate }\end{array}$ & -- & -- & -- & -- & -- & n.a & 0.5 & n.a \\
$\begin{array}{l}\text { Adjusted Financial } \\
\text { Transaction Tax }\end{array}$ & $\mathbf{0 . 5}$ & $\mathbf{0}$ & $\mathbf{0}$ & $\mathbf{0 . 5}$ & $\mathbf{1}$ & $\mathbf{2}$ & $\mathbf{1}$ & $\mathbf{2}$ \\
$\begin{array}{l}\text { Financial Transactions } \\
\text { Tax Sub-Index Score }\end{array}$ & $\mathbf{0 . 5}$ & $\mathbf{0}$ & $\mathbf{0}$ & $\mathbf{0 . 5}$ & $\mathbf{1}$ & $\mathbf{2}$ & $\mathbf{1}$ & $\mathbf{2}$
\end{tabular}

n.a.: not applicable

(a) Over time, Brazil has introduced two different financial transaction taxes, one on bank debit (CPMF) and one on financial operations (foreign exchange, insurance, credit), the IOF. The CPMF was in force until 2007, when it was revoked. The IOF remains in force, and taxes credit operations at a rate of 3 percent. The Government is considering reintroducing the bank debit tax (CPMF) in an effort to fight the fiscal deficit. Both have been found to distort financial intermediation, although the IOF is more punitive on credit operations. Furthermore, the rates and taxable operations of both taxes have been subject to continuous changes over time, and often the tax rate used on one of them has been raised to compensate for a decrease in the revenues collected by the other tax.

(b) In several countries there are a number of exceptions in the payment of the tax (for example, in Peru there are exemptions to the tax base that include deposits for payments of salaries or pensions). However, these exemptions are not aimed at reducing the adverse effect of the tax on access to financial services by the lowincome population.

The large differences across countries are evident from the table. Uruguay and Paraguay stand out for being the countries with the highest possible score since these taxes are not used at all in their financial systems. At the opposite end, Brazil and Chile obtain a score of zero. In both cases the tax is levied on credit transactions and neither country has legislation in place that could mitigate the effect of the taxes on financial inclusion. In Brazil, the tax on Financial Transactions (IOF for its acronym in Portuguese) is currently levied on credit ${ }^{66}$ at a rate of 3 percent on an annual basis; however, historically this tax has been applied to a large number of financial transactions, including securities transactions, and at high rates, for the purpose of stemming large capital inflows. In addition, the Brazilian authorities are currently considering the reintroduction of a tax on bank debit (the CPMF for its acronym in Portuguese) as a mechanism to boost public revenues. Specific characteristics and evolution of the IOF and CPMF taxes are discussed in Annex XVI.

66: The IOF is levied on credit, foreign exchange operations, insurance and security transactions. 
In Chile, the seal and stamp tax, is levied on consumption and mortgage credits. The tax base is the loan value and the tax rate equals 0.066 percent per month (with a maximum rate of 0.8 percent annually) The tax increased in 2016 from a previous annual rate of 0.4 percent. Since the rate is fixed for all types of credit, the effect of the tax is larger for loans of low value; therefore, low-income consumers and small and medium size enterprises are the most affected. ${ }^{67}$

Argentina, Colombia, Mexico and Peru have bank debit taxes in place. ${ }^{6}$ However, significant differences in regulations affecting the impact of the taxes on financial inclusion explain the differences in scores. For example, Peru receives an overall score of 1 since the tax payment can be fully deducted from personal income tax (mitigating factor a. in Table 11), and, importantly, the tax rate is very close to zero: 0.005 percent (mitigating factor c.). In fact, current legislation stipulates that a central reason for maintaining this tax is to obtain bank customer information to avoid tax evasion, money laundering and other financial crimes.

Although Mexico imposes a high tax rate ( 3 percent), the tax is imposed only on cash deposits that exceed 15,000 Mexican pesos (about US $\$ 750$ at the year-end 2016 exchange rate). Moreover, the amount paid for this tax can be fully credited against the personal income tax. Thus, Mexico's overall score of 1 is supported by the presence of mitigating factors a. and b. in Table 11.

With an overall score of 0.5 , Argentina and Colombia are the worst performers among those countries that use debit taxes. The main reason is that the only mitigating factor against the distortionary effects of the tax is the presence of exceptions in the payment of the tax (mitigating factor b.). In particular, in Argentina, transactions in simplified accounts are exempt from the tax.

In Colombia, each individual can hold one savings account, electronic deposit or prepaid card exempt from the tax. ${ }^{69}$ In addition, retirees can hold a second account, exempt from the tax, where their pensions can be deposited. Moreover, products aimed to promote financial inclusion (such as simplified accounts) also benefit from the exemption. In spite to its proven adverse effect on financial disintermediation, ${ }^{70}$ the tax was kept in place during the 2016 Tax Reform due to its importance as a source of fiscal revenues. ${ }^{71}$

\footnotetext{
${ }^{67}$ : See http://www.derechotributario.cl/2015/12/alza-de-impuesto-de-timbre-tendra-efecto-en-la-banca/

68: In Argentina and Peru, the tax is also levied on credit transactions.

69: Only if the sum of monthly transactions is up to 11 million Colombian pesos; about US $\$ 3,200$ at the year-end 2016 exchange rate.

70: Estimates from Asobancaria (2014) reveal that the demand for cash increased by 12 percentage points from 1999 (when the tax was introduced) to 2014.

71: According to the Colombian Comisión de Expertos para la Equidad y Competitividad Tributaria (Experts Commission for Equity and Competitiveness in Taxation (2015)) the financial transaction tax collected 0.8 percent of GDP by 2014. In the context of lower oil prices and fiscal vulnerabilities in Colombia, the Commission recommended maintaining the prevailing tax rate in the 2016 Fiscal Reform.
} 


\section{b. Preventer 2: Interest Rates Ceilings}

The authorities in countries that impose Interest Rate Ceilings on bank loans often use usury laws as the legal instrument to implement this policy. The reason is that the authorities' most common intention is to protect consumers (debtors) from paying excessive interest rates. Other types of rationale for capping interest rates involve allowing affordable credit to reach borrowers in certain sectors of the economy (such as the rural sector in Brazil). Despite its good intentions, however, the literature shows that this regulation has had counterproductive effects, since it has hindered access to credit for certain small enterprises and low-income individuals: in cases where the maximum interest rates allowed by law are insufficient to reflect the riskier characteristics of these type of customers, financial institutions have opted not to lend to these customers. In other cases, when the law permits, high fees and commissions are charged to offset the caps on interest rates. In any event, this regulation has often constrained financial sophistication as many SMEs and low-income individuals find that they can only meet their financial needs in the non-regulated informal markets. $^{72}$

The large majority of Latin American countries that impose caps on interest rates set maximum rates relative to a benchmark rate (as opposed to an absolute cap, which is a fixed nominal rate). ${ }^{73}$

In constructing the sub-index on Interest Rates Ceilings, we have used a single indicator that assesses whether: (a) caps are in place and (b) the extent to which existing caps are effectively distorting the provision of credit at the present time. In other words, while the presence of caps is generally considered a deterrent to financial deepening and financial inclusion, the legislation might not be binding at current rates. Alternatively, the caps could distort the allocation of some type of credit, but not that made to small firms and low-income households. In the worst-case scenario, the ceilings are adversely affecting credit to lowincome populations and firms. Thus, the indicator's scoring system penalises more countries where credit distortions, especially to low-income groups, are actually taking place, than countries where the potential exists for distortions, but where they were not materialising at the time of the assessment. The scoring system is presented in Annex I.K.

The main sources of information used in the score of each country are national legislation and information from Central Banks and Financial Supervisory authorities. Additional sources are listed in the Reference Section

The results from the assessment of our selected set of Latin American countries are presented in Table 14. A summary of the countries' regulatory characteristics can be found in Annex XVII.

\footnotetext{
72: See Munzele Maimbo and Henriquez Gallegos (2014) and Capera et.al. (2011)

73: According to Munzele Maimbo and Henriquez Gallegos (2014), among Latin American countries, only Venezuela was using an absolute cap as of 2014.
} 


\section{Table 14: The Sub-Index of Interest Rates Ceilings in Selected Latin American Countries. The Scores}

\begin{tabular}{|l|c|c|c|c|c|c|c|c|}
\hline Criteria / Country & Argentina & Brazil & Chile & Colombia & Mexico & Paraguay & Peru & Uruguay \\
\hline Interest rate ceilings & $1(a)$ & 0 & 0 & 0 & 2 & 1 & 2 & 0 \\
\hline $\begin{array}{l}\text { Interest rate ceilings Sub- } \\
\text { Index Score }\end{array}$ & 1 & 0 & 0 & 0 & 2 & 1 & 2 & 0
\end{tabular}

(a) The Government removed existing ceilings on interest rates charged on credit operations as well as the floor on deposit interest rates, but there are still limits imposed on rates on credit card transactions and on credits under directed lending programs. However, these limits do not seem to distort micro or low value credit. Furthermore, if the Government continued to maintain the ceilings high enough, and inflation reduction targets were achieved, the country would obtain a score of 1.5 , the highest among countries that have some form of cap in place.

Two countries in the sample, Mexico and Peru, do not use interest rate ceilings and, therefore, obtained the maximum score. By contrast, in Brazil, Colombia, Chile and Uruguay interest rate caps are in place and are reportedly assessed as creating important distortions in the provision of credit to small enterprises and low-income customers. ${ }^{74}$

In Argentina (with a score of 1), the new Government removed existing ceilings on interest rates charged on credit operations as well as the floor on deposit interest rates. As a result, compensatory interest rates are generally determined freely in the market, except from existing limits on rates for credit cards transactions, which are subject to a regulatory ceiling that has been found to create market distortions. Furthermore, directed lending programs in place (Linea de financiamiento para la producción y la inclusion financiera), which mandate banks to allocate a percentage of their deposits to finance predefined sectors and SMEs at rates set by the Central Bank seem also to generate distortions in credit markets. In 2016, the Government initiated a process of redesign of these policies to reduce the distortions and alleviate the burden on financial institutions.

Finally, Paraguay also obtained a score of 1 because of certain regulatory characteristics of ceilings on interest rates. While limits on interest rates on loans are not binding for any type of credit, including microloans (the cap is currently set at 130 percent of a moving average of

\footnotetext{
74: The Global Microscope (2016) assessed that sector-specific interest rates caps in Brazil have created significant distortions in the allocation of credit and driven up the cost of credit. In Chile, ABIF (2016) found that, following regulatory changes that reduced the cap on interest rates in December 2013, the number of low-income households that obtained credit from banks contracted (26 percent between 2013 and the first quarter of 2016). By contrast, the number of high-income debtors that obtained credit during the same period expanded by 33 percent. In Colombia, a recent study by ANIF (2016) found that the existing cap restricts access to credit for the low-income population. The study also reports that a liberalisation of interest rates could potentially benefit financial inclusion by allowing for an increase of around 20 percent in consumer credit and even more in microcredit. Finally, in Uruguay, Voelker (2011) reports a distortion in microcredit markets due to the methodology utilised by the Central Bank to establish the interest rate cap in this segment: the benchmark rate used to calculate the cap is based on the average of interest rates charged by regulated financial institutions on all types of credit. This rate, however, does not represent the operations of microfinance institutions.
} 
consumer lending rates) ${ }^{75}$ the introduction in 2015 of a regulation limiting interest rates on credit cards has reduced the use of these instruments. Although credit cards are used less by the low-income segments of the population, the new regulation has created distortions in the credit markets and has increased the difficulties of small firms in obtaining access to this finance mechanism.

\section{c. Preventer 3: Directed Lending}

Direct government intervention in credit markets with the aim of expanding access to credit by selected sectors can take different forms. The two forms of intervention most commonly used in Latin America are: (a) directed lending programmes, through which the government mandates banks to allocate a certain share of their loan portfolio to selected sectors, and (b) state bank lending, which is performed through first or second tier government institutions (development banks). First-tier banks lend to the public directly, while second-tier banks lend to other financial institutions which subsequently lend on to end customers.

Interventions through development banks can play an important role for financial inclusion in the presence of market failures (due to their strong focus on SMEs and individuals not served by other financial institutions), but only if their actions do not create additional market distortions. Indeed, the extensive literature on the subject concludes that the role of the government in finance must be limited to complementing, rather than substituting, private sector efforts. ${ }^{76}$ This suggests that second-tier development banks are more efficient, less costly and more effective than first-tier banks in addressing market failures (Marulanda and Paredes, 2005). ${ }^{77}$

In this context, the methodology for constructing the sub-index of Directed Lending (presented in Annex I.L) is based on an indicator whose value decreases as the market distortions created by government intervention increase. In the optimal scenario, the government simply does not interfere in the allocation of credit or its interventions are executed through second-tier banks that support and complement the existing efforts of the private sector. At the opposite end, the government intervenes by directly lending to selected customers in a way that competes with private banks or by mandating private banks to lend to specific sectors at pre-specified rates.

\footnotetext{
75 See World Bank (2014).

76: This view is supported by Marulanda and Paredes (2005), Vives (2005), De Luna-Martínez and Vicente (2012), World Bank (2013)

77: De Luna-Martínez and Vicente (2012) brought forward several arguments that support this view. First, second-tier development banks tend to have lower operating costs because financing is provided by the development banks to private financial institutions which subsequently select and assess the loan applications of end customers. Therefore, under this model the development bank can reach more end customers and cover more locations without incurring high operating costs. Second, credit risk is partially absorbed by the private financial institution that intermediates the development banks' funds. Finally, second-tier banks tend to report lower non-performing loan ratios than first-tier banks.
} 
National legislation and additional sources listed in the Reference Section were used to estimate the scores for the countries under study. The results for the sub-index Directed Lending are presented in Table 15. Annex XVIII presents a summary of countries' regulatory features.

Table 15: The Sub-Index of Directed Lending in Selected Latin American Countries. The Scores

\begin{tabular}{|l|c|c|c|c|c|c|c|c|}
\hline Criteria / Country & Argentina & Brazil & Chile & Colombia & Mexico & Paraguay & Peru & Uruguay \\
\hline Directed lending & 0 & 0 & 2 & 0 & 2 & 0 & 2 & 0 \\
\hline $\begin{array}{l}\text { Directed Lending Sub- } \\
\text { Index Score }\end{array}$ & 0 & 0 & 2 & 0 & 2 & 0 & 2 & 0
\end{tabular}

Chile, Mexico and Peru are the best performers in this category and obtain the maximum score. Development banks are present in these countries, but they do not create distortions in the allocation of credit. In Chile, Banco del Estado, the only development bank, is a firsttier bank that competes under market conditions with private commercial banks. In Mexico, development banks operate as second-tier institutions and channel their funding to strategic sectors through private banks, which make the individual credit decisions. According to the World Bank (2013), this model of operation has prevented the eruption of distortions in the credit markets. In Peru, the Financial Sector Law establishes that the Government must not intervene in the financial sector, except for its investment in four development banks; one of which, COFIDE, acts fully as a second-tier bank. Agrobanco and Banco de la Nacion may act as first-tier banks, but their activities are not perceived as distortionary.

The other countries in the sample obtain a score of zero. In Argentina, the Government significantly influences the allocation of credit: there are both directed lending programmes forcing financial institutions to invest in certain projects and state banks acting as first-tier banks. In Brazil, distortions associated with directed lending are abundant. For example, between 2010 and 2015, about 42 percent of Brazilian credit resources were earmarked and most of this credit (over 90 percent) was provided by the National Development Bank (BNDES), the Rural Credit National System (SNCR) and the Housing National System (SNH). In Brazil, directed lending combined with lending from first-tier public banks to create multiple distortions in the allocation of credit. In Paraguay, first-tier public institutions have benefited from preferential treatment from the Government and some of these banks are catering to sectors which are already being served by private banks. Preferential treatment to public banks is also found in Uruguay. For example, the Government provides explicit unlimited and permanent guarantees to first-tier banks, Banco República and Banco Hipotecario, thus providing them with a competitive edge.

Colombia is a more complex case. There is one first-tier public bank, several governmentcontrolled financial institutions and trust companies and three second-tier stated-owned development banks. Legislation for the functioning of Finagro, a Government Fund promoting the development of micro-, small- and medium-sized agricultural firms, points to the presence of credit market distortions. The regulation mandates private financial 
institutions to invest a percentage of their resources in Finagro's securities (Titulos de Desarrollo Agropecuario-TDAs), with very low profitability. Finagro, in turn, acts as a second-tier bank and channels these funds towards the agricultural sector through rediscount lines granted to first-tier banks. Agricultural loans are provided at interest rates set by the authorities. The evidence indicates that the fixed interest rates do not cover the costs and risks associated with funding small producers. Legislation, however, allows private banks to substitute the mandatory investments in TDAs with credit granted directly to the agricultural sector using banks' own resources. This has created an incentive for banks to avoid the large opportunity costs associated with investing in TDAs by providing direct credit to large- and medium-sized producers, whose lower risks characteristics can be covered by the fixed interest rates set by the government. Thus, while on the one hand, the TDA scheme penalises private banks, on the other the scheme can be avoided but at the cost of reducing lending to small-size agricultural producers. Indeed, although the legislation permits, and actually encourages, avoidance of contributions to Finagro, the alternative for the banks is to face directed lending with interest rate caps that distort the allocation of credit and hurt financial inclusion.

\section{The Preventers Index}

Table 16 presents the Preventers index and its components. The value of the overall index is the simple average of the scores obtained for the three sub-indices

Table 16: The Preventers Index in Selected Latin American Countries. The Scores

\begin{tabular}{|l|c|c|c|c|c|c|c|c|}
\hline Criteria / Country & Argentina & Brazil & Chile & Colombia & Mexico & Paraguay & Peru & Uruguay \\
\hline $\begin{array}{l}\text { Adjusted Financial } \\
\text { Transaction Taxes }\end{array}$ & 0.5 & 0 & 0 & 0.5 & 1 & 2 & 1 & 2 \\
Interest rate ceilings & 1 & 0 & 0 & 0 & 2 & 1 & 2 & 0 \\
Directed lending & 0 & 0 & 2 & 0 & 2 & 0 & 2 & 0 \\
Preventers Score & 0.5 & 0 & 0.7 & 0.2 & 1.7 & 1 & 1.7 & 0.7 \\
\hline
\end{tabular}

The highest score for this index was obtained by Mexico and Peru (with a score of 1.7) largely because both countries received maximum scores in the sub-indices for Interest Rates Ceilings and Directed Lending.

At the opposite end is Brazil with the lowest possible score in the three components in the index, closely followed by Colombia and Argentina with scores of only 0.2 and 0.5. Chile and Uruguay also received very low scores, followed by Paraguay. While Chile and Uruguay received the lowest possible score in two out of the three sub-indices, and the highest possible score in a third one, Argentina and Paraguay are more complex cases where the scores were all over the place. Interestingly, in spite of their relatively low overall scores, Paraguay and Uruguay stand out as the only two countries in the sample that do not have financial transaction taxes in place. 


\section{The Overall Index of Regulations for Financial Inclusion}

We have now reached the final stage of this exercise where the three estimated indices, the Enablers, the Promoters (adjusted) and the Preventers, can be combined to obtain an Overall Index of Regulations for Financial Inclusion. Table 17 presents that index and its components. The value of the overall index is the simple average of the scores obtained for the three components.

Table 17: The Overall Index of Regulations for Financial Inclusion in Selected Latin American Countries. The Scores

\begin{tabular}{|l|c|c|c|c|c|c|c|c|}
\hline Criteria / Country & Argentina & Brazil & Chile & Colombia & Mexico & Paraguay & Peru & Uruguay \\
\hline Enablers Index & 1.2 & 1.4 & 1.7 & 1.5 & 1.6 & 1.9 & 1.8 & 1.5 \\
$\begin{array}{l}\text { Adjusted Promoters } \\
\text { Index }\end{array}$ & 1.1 & 1.4 & 1.25 & 1.75 & 1.35 & 1.4 & 1.9 & 1.5 \\
Preventers Index & 0.5 & 0 & 0.7 & 0.2 & 1.7 & 1 & 1.7 & 0.7 \\
\hline Overall Index Score & 0.9 & 0.9 & 1.2 & 1.2 & 1.6 & 1.4 & 1.8 & 1.2
\end{tabular}

Peru ranks first as it had the highest score among the selected countries. Mexico followed it closely. Both countries scored well in the Enablers index, but obtained very different results in the Adjusted Promoters and Preventers indices. While Peru received a very high score in the former and a low score in the latter, Mexico obtained opposite results.

With a score of 1.4, Paraguay takes third place. The country stands out due to the soundness of its Enabling regulations (where it obtained the highest score among all countries), but displayed important shortcomings in the other two indices.

Chile, Colombia and Uruguay share a common low score of 1.2. Just as with Paraguay, for Chile a high score in the Enablers index cannot offset low scores in the other two indices. In Colombia, the extremely low score of the Preventers index brings the value of the Overall Index down. This despite the relatively high score of the Adjusted Promoters index, where it was second only to that of Peru.

Uruguay does not achieve high scores in any of the three indices. This feature is shared with Argentina and Brazil, the two countries with the lowest overall scores. In these countries, major changes are needed if their regulatory frameworks are to reach their potential for improving financial inclusion.

A word of caution is important here. While central for financial inclusion, regulation is not the only factor influencing the demand for and the provision of financial services. Many constraints, such as institutional weaknesses, poverty, income inequality and macroeconomic imbalances can prevent improvements in financial inclusion. These obstacles can explain some stylized facts. For example, while Peru and Mexico obtain the top positions in the ranking regarding the quality of regulatory practices, they display very low levels of financial inclusion (World Bank Global Findex 2014). As identified in Rojas-Suarez (2016) 
institutional weaknesses might be the most important constraint for financial inclusion in these two countries.

The calculation of the scores has used a methodology that acknowledges both the peculiarities of Latin America and the interactions between the assessed regulations and those between regulatory practices and other types of government interventions in support of financial inclusion. It is our hope that these results serve to guide regulatory reforms. As stated at the outset, there is surely no unique way to define and aggregate the indicators, and different country rankings could be achieved if alternative scoring definitions or weights were defined. Thus, once again we invite interested researchers to explore alternative methodologies that could guide future updates of this exercise. Beyond specific scores, perhaps an even more important contribution of this paper lies in identifying with some detail the areas of strengths and weaknesses in financial regulatory practices for improving financial inclusion. Thus, as a way of closing, Table 18 summarises these areas for each country and Chart 1 graphically presents the scoring results for the 11 regulatory indicators plus the indicator for financial literacy. 
Table 18: Regulatory provisions for financial inclusion in selected Latin American countries. Main strengths and weaknesses

\begin{tabular}{|c|c|c|}
\hline & Strengths & Weaknesses \\
\hline Argentina & $\begin{array}{l}\text { - Strong provisions for contestability and interoperability of relevant inputs } \\
\text { enhance the quality of competition policies } \\
\text { - There is a dedicated regulatory framework for simplified accounts and these } \\
\text { are used to distribute conditional cash transfers } \\
\text { - Credit reporting systems cover comprehensive information that is safe and } \\
\text { widely accessible for lenders and borrowers } \\
\text { - Proportionate regime for KYC }\end{array}$ & 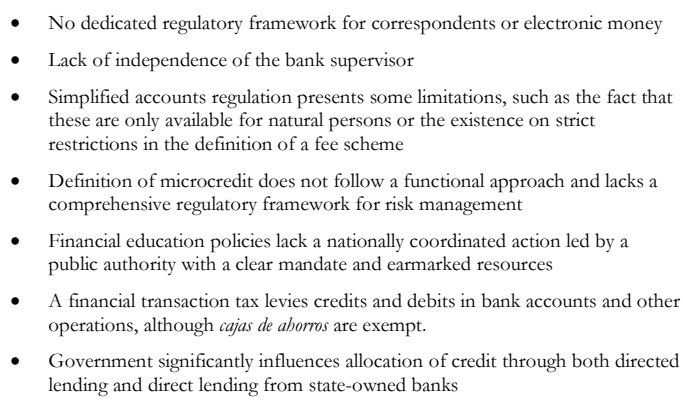 \\
\hline Brazil & $\begin{array}{l}\text { - Coordinated, comprehensive and targeted effort to enhance financial literacy } \\
\text { - Proportionate regime for KYC } \\
\text { - Supervisory framework rests on strong powers } \\
\text { - Dedicated framework for simplified accounts, which are used to distribute } \\
\text { conditional cash transfers } \\
\text { - Regulatory provisions on electronic money follow best practices } \\
\text { - Regulatory framework for correspondents in place for a long time, with } \\
\text { adequate provisions on accountability and comprehensive on the business } \\
\text { models and activities allowed } \\
\text { - Credit reporting systems are widely accessible for lenders and borrowers, with } \\
\text { sound provisions to ensure protection of personal data }\end{array}$ & $\begin{array}{l}\text { - The imposition of a tax on financial operations, directed lending through } \\
\text { recursos direcionados and lending from first-tier public banks, and caps on } \\
\text { interest rates create multiple distortions } \\
\text { - Additional government efforts to promote usage of simplified accounts crowd } \\
\text { out private sector efforts } \\
\text { - Restrictions on fees and commissions for simplified accounts might limit their } \\
\text { commercial appeal } \\
\text { - Potential of electronic money is not harnessed for the distribution of } \\
\text { conditional cash transfers } \\
\text { - Scheme of fees and commissions in the correspondents business model is not } \\
\text { aligned with best practices } \\
\text { - Microcredit lacks a comprehensive prudential regulation and supervision } \\
\text { framework tailored to the specificities of this activity } \\
\text { - Obstacles or gaps in the legislation of the Cadastro Positivo limit the availability } \\
\text { of positive information in private bureaus }\end{array}$ \\
\hline Chile & $\begin{array}{l}\text { - Strong competition policies } \\
\text { - Supervisory framework rests on strong monitoring and enforcement powers } \\
\text { - Simplified accounts offered by the public bank BancoEstado are seized for the } \\
\text { distribution of conditional cash transfers } \\
\text { - Regulatory framework to allow the issuance of prepaid cards by non-bank } \\
\text { institutions has recently been approved, although technical details are still } \\
\text { pending } \\
\text { - All providers of credit, regulated or not, are subject to consumer protection } \\
\text { and disclosure rules } \\
\text { - Credit reporting systems are widely accessible for lenders and borrowers and } \\
\text { there are sound provisions to ensure the protection of personal data }\end{array}$ & $\begin{array}{l}\text { - The imposition of a financial transaction tax levied on credit operations and } \\
\text { limits on interest rates create multiple distortions } \\
\text { - There is no dedicated regulatory framework for simplified accounts } \\
\text { - Potential of electronic money is not harnessed for the distribution of } \\
\text { conditional cash transfers } \\
\text { - There is no dedicated regulatory framework for correspondents, which could } \\
\text { lead to regulatory uncertainty as regards the activities that these agents can } \\
\text { perform or the fees they might charge } \\
\text { - Microcredit lacks a formal definition and a comprehensive prudential } \\
\text { regulation framework tailored to the specificities of this activity } \\
\text { - Private bureaus are only allowed to gather negative Credit reporting and there } \\
\text { are regulatory provisions limiting the historical data available on small-volume } \\
\text { borrowers } \\
\text { - Rules on KYC lack sufficient clarity as regards record-keeping and on how } \\
\text { financial institutions can verify their customers' identity }\end{array}$ \\
\hline Colombia & $\begin{array}{l}\text { - Strong competition policies } \\
\text { - Simplified accounts are seized for the distribution of conditional cash } \\
\text { transfers, are accessible through convenient channels and providers are given } \\
\text { sufficient room to design viable business models } \\
\text { - Regulatory provisions on electronic money mostly follow best practices and } \\
\text { its potential is harnessed for the distribution of conditional cash transfers } \\
\text { - Regulatory provisions on correspondents follow best practices } \\
\text { - Microcredit is formally defined and there is a comprehensive regulatory } \\
\text { framework for risk management, although it could benefit from tailored loan } \\
\text { documentation requirements } \\
\text { - Simplified KYC regime is allowed for financial products or services that aim } \\
\text { at financial inclusion, although the regime could benefit from additional clarity } \\
\text { on record-keeping } \\
\text { - Credit reporting systems cover comprehensive information that is safe and } \\
\text { widely accessible for lenders and borrowers } \\
\text { - Financial education policies are delivered through convenient channels and } \\
\text { included in the design of welfare programmes }\end{array}$ & $\begin{array}{l}\text { - The } 2016 \text { tax reform has stopped the progressive elimination of the financial } \\
\text { transaction tax }(4 \times 1000) \text {, although some products aimed to promote financial } \\
\text { inclusion are exempted } \\
\text { - There is a limit on interest rates that has been found to restrict access to credit } \\
\text { for low income population } \\
\text { - State interventions through directed lending in the agricultural sector is } \\
\text { creating distortions in credit markets } \\
\text { - The simplified accounts regulation has some limitations, such as the fact that } \\
\text { these are only available for natural persons }\end{array}$ \\
\hline
\end{tabular}




\begin{tabular}{|c|c|c|}
\hline & Strengths & Weaknesses \\
\hline Mexico & $\begin{array}{l}\text { - Strong competition policies } \\
\text { - Supervisory framework rests on strong powers } \\
\text { - Proportionate regime for KYC } \\
\text { - Credit reporting systems cover comprehensive information that is safe and } \\
\text { widely accessible for lenders and borrowers } \\
\text { - Comprehensive regulatory framework on simplified accounts that allows } \\
\text { individuals and small firms to access this product via convenient channels } \\
\text { - No ceilings are set on interest rates } \\
\text { - State intervention in credit markets is conducted through second-tier lending } \\
\text { by public development banks without evidence of distortions } \\
\text { - All providers of credit, regulated or not, are subject to consumer protection } \\
\text { and disclosure rules } \\
\text { - Financial education policies are delivered through convenient channels and } \\
\text { included in the design of welfare programmes } \\
\text { - Banks and other entities in the popular credit and savings systems are allowed } \\
\text { to offer a wide range of services through correspondents }\end{array}$ & $\begin{array}{l}\text { - No regulatory framework in place allows the provision of electronic money by } \\
\text { non-banks } \\
\text { - Potential of simplified accounts is not harnessed for the distribution of } \\
\text { conditional cash transfers } \\
\text { - Restrictions on fees and commissions charged for simplified accounts might } \\
\text { impede the design of attractive business models } \\
\text { - The supervisory processes for authorising and overseeing the operation of } \\
\text { correspondents is complex and time-consuming }\end{array}$ \\
\hline Paraguay & $\begin{array}{l}\text { - Strong competition policies } \\
\text { - Supervisory framework rests on strong powers and regulatory provisions that } \\
\text { ensure the independence of the supervisor } \\
\text { - Dedicated regulatory framework on simplified accounts that allows their } \\
\text { provision through convenient channels } \\
\text { - Potential of electronic money can be harnessed for the distribution of } \\
\text { conditional cash transfers } \\
\text { - Rules on correspondents allow banks to offer a wide range of services } \\
\text { through correspondents while ensuring adequate supervision and giving } \\
\text { sufficient freedom to set fees and commissions } \\
\text { - Credit reporting systems are widely accessible for lenders and subject to } \\
\text { strong data protection rules } \\
\text { - There is not a financial transaction tax in place }\end{array}$ & $\begin{array}{l}\text { - Regulations on simplified accounts, correspondents, microcredit or the } \\
\text { simplified KYC regime do not apply to institutions other than banks, such as } \\
\text { credit cooperatives } \\
\text { - Simplified accounts are only available for natural persons and regulation } \\
\text { imposes strict restrictions on the fees to be charged } \\
\text { - Additional government efforts to promote usage of simplified accounts crowd } \\
\text { out private sector efforts } \\
\text { - Rules on electronic money do not impose capital requirements on non-bank } \\
\text { providers to ensure adequate protection of funds } \\
\text { - Non-regulated credit providers are not subject to consumer protection and } \\
\text { - Iisclosure rules } \\
\text { - Information contained in Credit reporting systems is not comprehensive as } \\
\text { regards the sources and nature of the information } \\
\text { - KYC rules could be streamlined to favour financial inclusion. } \\
\text { - Financial education policies lack a nationally coordinated action led by a } \\
\text { public authority with a clear mandate and earmarked resources } \\
\text { State interventions through directed lending create distortions }\end{array}$ \\
\hline Peru & $\begin{array}{l}\text { - Supervisory framework rests on strong powers and regulatory provisions that } \\
\text { ensure the independence of the supervisor } \\
\text { - Competition policies benefit from rules that ensure contestability of relevant } \\
\text { inputs and interoperability } \\
\text { - Dedicated regulatory framework on simplified accounts that allows their } \\
\text { provision through convenient channels } \\
\text { - Regulatory provisions on electronic money follow best practices } \\
\text { - Microcredit is formally defined and subject to a comprehensive regulatory } \\
\text { - } \quad \text { Rules on correspondents largely follow best practices } \\
\text { - Proportionate regime for KYC } \\
\text { - Credit reporting systems cover comprehensive information that is safe and } \\
\text { - } \text { widely accessible for lenders and borrowers } \\
\text { Coordinated, comprehensive and targeted effort to enhance financial literacy }\end{array}$ & $\begin{array}{l}\text { - The simplified accounts regulation has some limitations, such as the fact that } \\
\text { these are only available for natural persons } \\
\text { - Additional government efforts to promote usage of simplified accounts crowd } \\
\text { out private sector efforts } \\
\text { - Potential of electronic money is not harnessed for the distribution of } \\
\text { conditional cash transfers }\end{array}$ \\
\hline Uruguay & $\begin{array}{l}\text { - Supervisory framework rests on strong powers } \\
\text { - Simplified accounts regulation allows individuals and small firms to access this } \\
\text { product } \\
\text { - Dedicated regulatory framework for the issuance of electronic money by non- } \\
\text { banks, which fosters payments of salary, pension or social benefits through } \\
\text { this instrument } \\
\text { - Rules on correspondents allow banks to offer a wide range of services } \\
\text { through correspondents giving sufficient freedom to set fees and } \\
\text { commissions } \\
\text { - Credit reporting systems cover comprehensive information that is safe and } \\
\text { - Pridely accessible for lenders and borrowers } \\
\text { - There is no financial transaction tax in place }\end{array}$ & $\begin{array}{l}\text { - Potential of electronic money is not harnessed for the distribution of } \\
\text { conditional cash transfers } \\
\text { - Simplified accounts regulation has some limitations, for instance regarding the } \\
\text { permitted opening channels } \\
\text { - Rules on electronic money do not impose capital requirements on non-bank } \\
\text { providers to ensure adequate protection of funds } \\
\text { - Regulation does not provide for interoperability of agent networks } \\
\text { - Promotion of financial education lacks a nationally coordinated action led by } \\
\text { a public authority with a clear legal mandate, as well as incorporating this goal } \\
\text { in welfare programmes } \\
\text { - Microcredit lacks a formal definition and a comprehensive prudential } \\
\text { regulation framework tailored to the specificities of this activity } \\
\text { - Interest rate ceilings and direct state interventions in credit markets create } \\
\text { multiple distortions }\end{array}$ \\
\hline
\end{tabular}


As the table show, despite significant differences in the overall scores, all countries show important areas of strengths and weaknesses. It is not necessary to repeat them here since they have been already discussed extensively throughout the document. In each country, the task for policymakers is to deal with their individual regulatory shortcomings. Future updates of estimates in this paper can serve as a useful tool to assess the extent of progress. Moreover, in the context of an evolving financial landscape that brings new opportunities but also new challenges for financial inclusion, further research is needed to continue improving the methodology for adequate assessment and comparisons between the countries. 


\section{Chart 1: Scores values for the components of The Overall Index of Regulations for Financial Inclusion in Selected Latin American Countries}
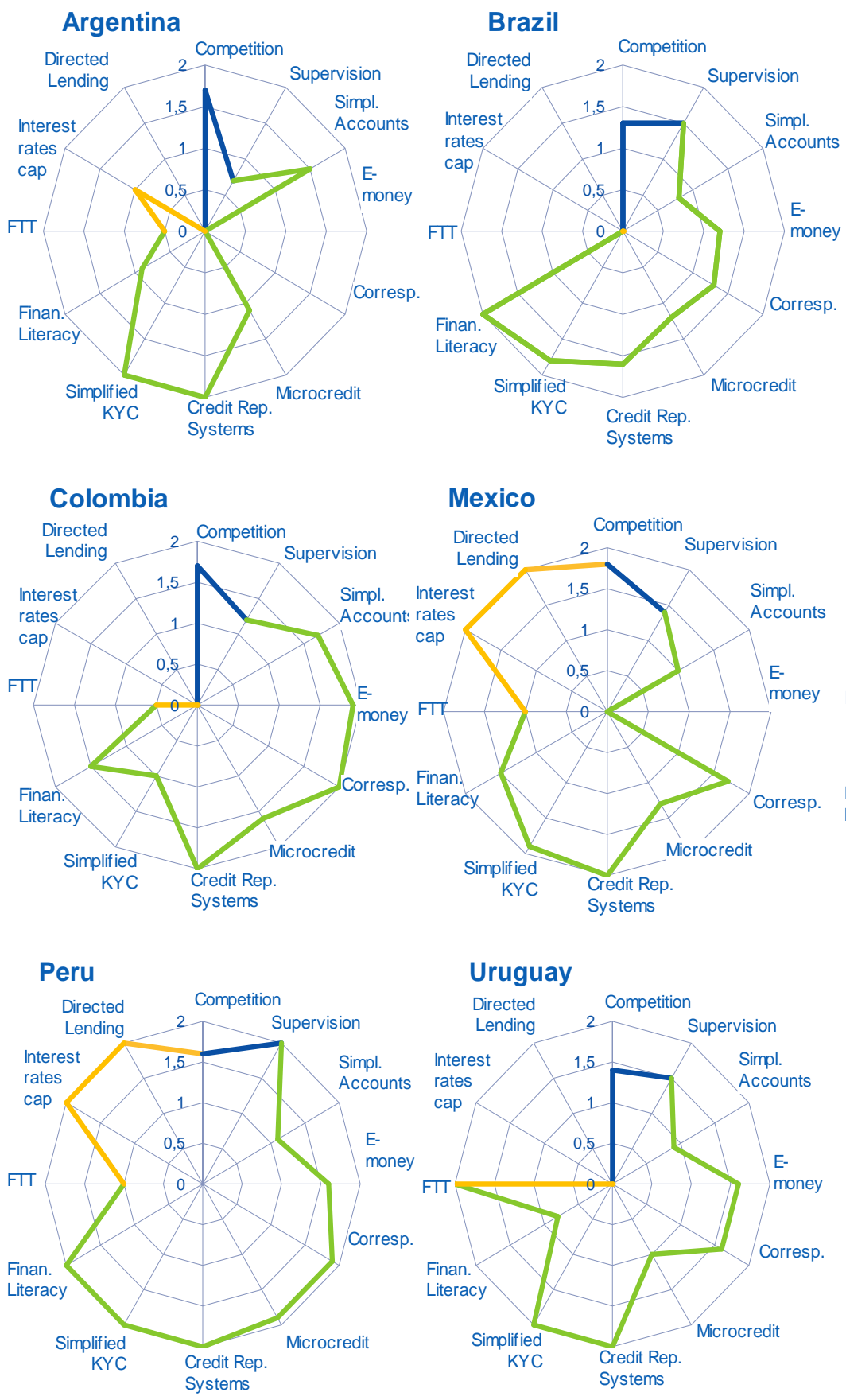
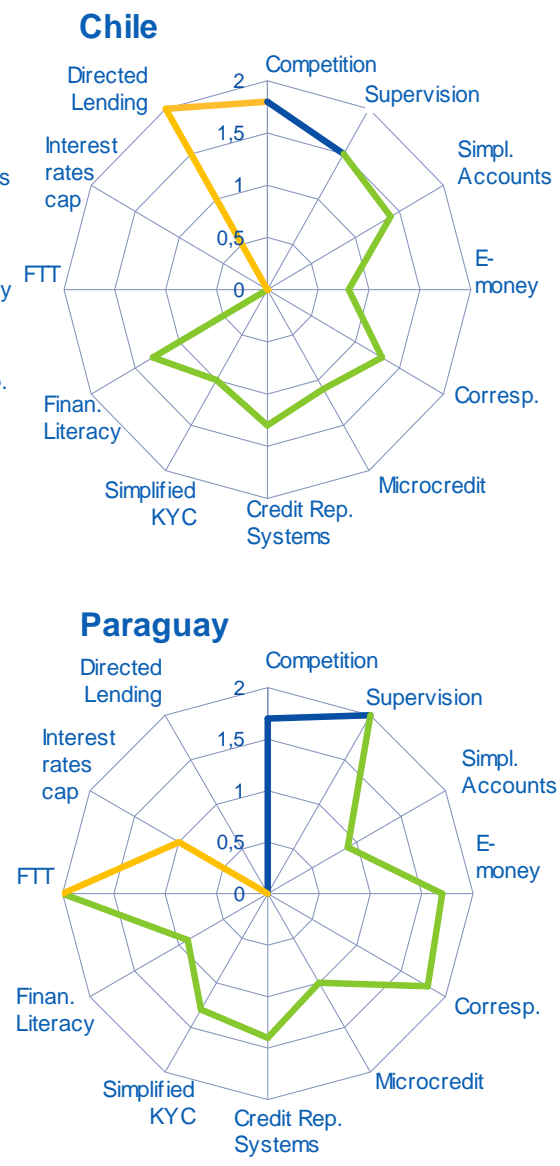


\section{References}

ASBA,2010, Guidelines of principles for effective regulation and supervision of microfinance operations Bank for International Settlements, 2015, "FSI Survey: Basel 2, 2.5 and 3 Implementation", July

Basel Committee on Banking Supervision, 2016, "Guidance on the Application of the Core Principles for

Effective Bank Supervision to the Regulation and Supervision of Institutions Relevant to Financial Inclusion, Bank for International Settlements, December.

-------, 2012, “Core Principles for Effective Banking Supervision”, Basel, October

----------, 2010 Microfinance activities and the Core Principles for Effective Banking Supervision

Beck, Thorsten and Augusto de la Torre, 2006, "The Basic Analytics of Access to Financial Services" Policy Research Working Papers No. 4026. Washington DC: The World Bank

Bikker, Jacob and Laura Spierdijk, 2009, "Measuring and Explaining Competition in the Financial Sector" Journal of Applied Business and Economics

Brookings, Center for Technology Innovation (2017), The 2017 Brookings Financial and Digital Inclusion Project Report: Building a Secure and Inclusive Global Financial Ecosystem, Washington DC, August.

CAF, 2013a. Banca Corresponsal e Inclusión Financiera: Marcos regulatorios en América Latina

CAF, FOMIN and TEC-IN, 2013, Banca Corresponsal e Inclusión Financiera: Marcos regulatorios en América Latina

Cámara, N., Tuesta, D. y Urbiola, P. (2015). Extendiendo el acceso al sistema financiero formal: el modelo de corresponsales bancarios. Documento de Trabajo BBVA Research.

Capera, L., Estrada, D., Murcia, A. 2011. Efectos de los límites a las tasas de interés sobre la profundización financiera. Reporte de Estabilidad Financiera del Banco de la República de Colombia.

Castellanos, Sara G., Del Ángel, Gustavo A.,Garza-García, Jesús G.; 2015, Competition and Efficiency in the Mexican Banking Industry. Chapter 6: Competition Policy in the Mexican Financial System.

CGAP, 2015. Supervision of banks and nonbanks operating through agents

-----------, 2012, “A Guide to Regulation and Supervision of Microfinance: Consensus Guidelines”, October

--------, 2011a. Regulating Banking Agents. Focus Note

, 2011b. Credit Reporting at the Base of the Pyramid. Key issues and success factors. Report for the September 2011 Access to Finance Forum.

-----------, 2011c. Transferencias de efectivo con fines sociales e inclusion financiera: Experiencia en cuatro países

CEPAL. Base de datos de programas de protección social no contributiva en América Latina y el Caribe. http://dds.cepal.org/bdptc/\#es

Claessens, Stijn and Liliana Rojas-Suarez, 2016, "Financial Regulations for Improving Financial Inclusion, Center for Global Development, March

Claessens, Stijn, 2009, "Competition in the Financial Sector: Overview of Policies." IMF Working Paper, No $\mathrm{WP} / 09 / 45$

CNBV, 2011. Corresponsales bancarios en América Latina. Análisis comparativo de la experiencia con corresponsales en Brasil, Colombia, México y Perú.

De Luna-Martínez, J., Vicente, C.L. 2012, Global Survey of Development Banks. World Bank, Policy

Research Working Paper 5969. February 2012

di Castri, Simone, 2013, Mobile Money: Enabling Regulatory Solutions”, GSMA, February

Dos Santos, V.; Espinato, C. 2015, The impact of regulation on the success of simplified savings accounts in promoting financial inclusion in Latin America. Working Paper Series, No. 05-2015. 
The Economist Intelligence Unit, 2015, “Global Microscope 2015: The Enabling Environment for Financial Inclusion"

---------, 2016, Global Microscope 2016: The Enabling Environment for Financial Inclusion

GSMA, 2016 "Safeguarding Mobile Money: How Providers and Regulators can Ensure that Customer Funds are Protected", January

---------, 2015, "State of the Industry Report: Mobile Money"

----------, Mobile Money deployment tracker. Available at:

http://www.gsma.com/mobilefordevelopment/m4d-tracker/mobile-money-deployment-tracker

IADB, 2005. Unlocking credit. The quest for deep and stable bank lending. IPES 2005

IMF, "Financial Sector Assessment Program", various countries and years

, Article IV Consultation reports, various countries and years

----------, "Detailed Assessment of Compliance--Basel Core Principles for Effective Banking Supervision", various countries and years

-----------, 2016, "Financial Integration in Latin America, March

Marulanda, B., Paredes, M., 2005. La evolución y perspectivas de la banca de desarrollo en Latinoamérica frente al caso colombiano. CEPAL. Serie Financiamiento del Desarrollo, 153.

Mirzaei, Ali and Tomoe Moore, 2014, "What are the driving forces of bank competition across different income groups of countries?” Lournal of International Financial Markets, Institutions and Money, 2014, vol. 32, issue $\mathrm{C}$, pages $38-71$

Muzele Maimbo, S., 2014, Interest rate Caps around the World. Still Popular, but a Blunt instrument. World Bank Policy Research Working Paper 7070.

Pacho Trigueros, M, 2013, Hechos estilizados de los Impuestos a las Transacciones Financieras en América Latina: 1990=2012. Centro Interamericano de Administraciones Tributarias

Planet Finance, 2011. Estudio sobre el marco normativo de las microfinanzas en Latinoámerica.

Poblete, M. 2012. An overview of the experience with banking transaction taxes in Latin America. BBVA Research Watch.

Robles, M.; Rubio, M.G; Stampini, M. 2015 ¿Las transferencias monetarias han sido capaces de llegar a los pobres de América Latina y el Caribe? Resumen de políticas del BID. Banco Inter-Americano de Desarrollo

Rojas-Suarez, Liliana, 2016, Financial Inclusion in Latin America: Facts, Obstacles and Central Banks' Policy Issues, IDB Discussion Paper No. IDB-DP-464, June

--------, 2012, La Experiencia del Impuesto a las Transacciones Financieras en América Latina: Temas y Lecciones. Presentación realizada en el VIII Seminario sobre la Agenda de Desarrollo Iberoamericana organizada por CIDOB, ESADE, SEGIB y CEPAL; file:///C:/Users/lrojassuarez/Downloads/Liliana+Rojas-Su $\%$ C3\%A1rez+ADI+2012+Sesi $\% \mathrm{C} 3 \% \mathrm{~B} 3 \mathrm{n}+2 \% 20(1)$.pdf

---------, 2007, The Provision of Banking Services in Latin America: Obstacles and Recommendations, Working Paper 124, Center for Global Development, June

Secretaria General Iberoamericana, 2006, La extension del crédito y los servicios financieros. Obstáculos, propuestas y buenas prácticas.

Sahay, R, M Cihak, P N’Diaya, A Barajas, S Mitra, A Kyobe, Y Nian Mooi and R Yousefi, 2015, Financial inclusion: can it meet multiple macroeconomic goals, IMF Staff Discussion Notes, no 15/17.

Tarazi, M., Kumar, K. 2011. Branchless banking interoperability and agent exclusivity. CGAP Blog. Available at: https://www.cgap.org/blog/branchless-banking-interoperability-and-agent-exclusivity

Tecnocom, 2015, Informe sobre tendencias en medios de pago 2014. Capítulo 5: Al detalle: Pagos gubernamentales (G2P). Informe Tecnocom en colaboración con AFI 
Trujillo-Tejada e.t al.,2015, How is microfinance being regulated in Latin America?

Vives, A., 2005, Banca de desarrollo. Condiciones para una gestión eficiente. BID, Serie de informes técnicos del Departamento de Desarrollo Sostenible

World Bank, 2016a. Doing business, Getting Credit Methodology. Available at: http://www.doingbusiness.org/Methodology/Getting-Credit

------------, 2016b. Doing Business 2017. Getting Credit: credit information. Casting a wide net to expand financial inclusion.

2015, Global Financial Development Report. Long-term Finance.

World Bank Global Findex Database 2014. Measuring Financial Inclusion Around the World, http://www.worldbank.org/en/programs/globalfindex

, 2013, Global Financial Development Report 2013. Rethinking the role of the State in Finance. Chapter 4: Direct State Interventions.

------------, 2012, "Developing a Comprehensive National Retail Payments Strategy: Consultative Report." Washington DC.

World Bank, 2011a. General Principles for Credit Reporting

\section{Additional Sources}

\section{Competition Policies}

Barth, James Gerard Caprio and Ross Levine, 2013. "Bank regulation and supervision in 180 countries from 1999 to 2011 ” Paper and database. World Bank.

BBVA Research Watch (2016). Resolution regimes in Latin America

COFECE, 2014, “Trabajo de Investigación y recomendaciones sobre las condiciones de competencia en el sector financiero y sus mercados en México"

Eraso Lomaquiz, Santiago, 2016. El dinero electrónico en el Derecho Argentino. Revista Jurídica La Ley, 2017-A.

World Bank. Bank Regulation and Supervision Survey. Published in 2013 and conducted in 2011-2012. Dataset and Questionnaire.

\section{Supervisory Quality}

Barth, J., Caprio, G., Levine, R., 2013. Bank Regulation and Supervision in 180 Countries 1999 - 2011:

Measure It, Improve It

----------, 2005. Rethinking bank regulation. Till Angels Govern. Cambridge University Press

Economist Intelligence Unit (2016). Global Microscope 2016. The Enabling Environment for Financial Inclusion.

World Bank, 2012. Bank regulation and supervision survey. Last updated 2012. Available at: http://econ.worldbank.org/WBSITE/EXTERNAL/EXTDEC/EXTRESEARCH/0, contentMDK:203 45037 pagePK:64214825 piPK:64214943 theSitePK:469382,00.html

\section{Simplified Accounts}

Balbuena, C. 2013, "An account for my transfers: Potentials and Limitations of Electronic Government to Person Payments in the Promotion of Financial Inclusion". SBS 
CEPAL. "Base de datos de programas de protección social no contributiva en América Latina y el Caribe" http://dds.cepal.org/bdptc/\#es

CGAP, 2011, "Transferencias de efectivo con fines sociales e inclusión financiera: Experiencias en cuatro países"

FOMIN, 2015, "Estudio técnico sobre la inclusión financiera en Chile"

Robles, M.; Rubio, M.G; Stampini, M. 2015, ¿Las transferencias monetarias han sido capaces de llegar a los pobres de América Latina y el Caribe? Resumen de políticas del BID

LaTercera.com (02/14/2016). "Presidente de BancoEstado: "La Cuenta Rut nos da US\$ 37 millones de pérdidas todos los años". Available at: http://www.latercera.com/noticia/presidente-de-bancoestado-lacuenta-rut-nos-da-us-37-millones-de-perdidas-todos-los-anos/

\section{Electronic Money}

Balbuena, C. 2013, An account for my transfers: potentials and limitations of electronic government to person payments in the promotion of financial inclusion. SBS

BBVA Research, 2013, Observatorio Económico: El marco regulatorio del dinero electrónico en Perú y la inclusión financiera

Congreso de Colombia, 2014, Ley 1735: "Por el cual se Dictan Medidas Tendientes a Promover el Acceso a los Servicios Financieros Transaccionales y se Dictan otras Disposiciones", October 21

CNBV México, 2014, Reporte Inclusión Financiera nº . Pp. 25

Gobierno de Colombia, "Decreto 1491 de 2015 sobre Sociedades Especializadas en Depósitos y Pagos Electrónicos (SEDPE)

GSMA, 2015, Regulación y Políticas para el Dinero Móvil en Paraguay: Versión, dinámicas de mercado y perspectivas de la industria. Available at: http://www.gsma.com/mobilefordevelopment/wpcontent/uploads/2015/11/2015_GSMA Regulacion-y-Politicas-para-el-Dinero-Movil-en-Paraguay.pdf

IADI, 2013, "Financial Inclusion and Deposit Insurance".

Marulanda, Beatriz, 2009, PLAN DE ACCION Cómo Fomentar la Implementación del Acceso a Servicios Financieros a través Celulares

Ministerio de Hacienda de Colombia, Unidad de Regulación Financiera, 2014, Documento Técnico sobre Reglamentación de Sociedades Especializadas en Depósitos y Pagos Electrónicos.

Payments Compliance, 2014, Brazil's new payments regulation. Available at: https://gamblingcompliance.com/sites/gamblingcompliance.com/files/attachments/page/PaymentsCo mplianceBrazil.pdf

Presidente de Colombia, 2015, Reglamentación 1491 de 2015 sobre Sociedades Especializadas en Depósitos y Pagos Electrónicos (SEDPE), July 13

Sotomayor, N.,2012, Setting the Regulatory Landscape for the Provision of Electronic Money in Peru. SBS Working Paper

Stuber, W., 2013, Brazil: The new rules for payment institutions and payment arrangements in Brazil. Available at: http://www.mondaq.com/brazil/x/275958/Financial+Services/THE+NEW+RULES+FOR+PAYME NT+INSTITUTIONS+AND+PAYMENT+ARRANGEMENTS+IN+BRAZIL

UNCTAD, 2012, Mobile Money for business development in the East African Community. A Comparative Study of Existing Platforms and Regulations, http://unctad.org/en/PublicationsLibrary/dtlstict2012d2 en.pdf 


\section{Banking Correspondents}

Banco Central de la República Argentina (02/06/2016). Nota de Prensa. "El BCRA fomenta la apertura de sucursales bancarias en todo el país". Available at:

http://www.bcra.gov.ar/Pdfs/Prensa_comunicacion/NotadePrensaII_02-06-16.pdf

Banco Mundial (2014). Nota técnica. Regulaciones para la Inclusión Financiera en Paraguay

CAF, 2013b. Banca Corresponsal e Inclusión Financiera: Modelos de negocio en América Latina

CGAP, 2011. Reglamentación de los agentes bancarios

CGAP, 2010. Regulation of branchless banking in Argentina

El Economista (08/12/2013). Sector de ahorro y crédito popular crecerá con reforma financiera. Available at: http://eleconomista.com.mx/sistema-financiero/2013/12/08/sector-ahorro-credito-popular-crecerareforma-financiera-cnbv

KPMG Indonesia, 2015, New Indonesian Branchless Banking and Microfinance Laws - a catalyst for microfinance growth? Available at: https://assets.kpmg.com/content/dam/kpmg/pdf/2016/07/id-ksafinancial-inclusion-indonesia.pdf

\section{Microcredit}

Andina.com.pe. (20.11.2013). Más ONF solicitan convertirse en Edpymes. http://www.andina.com.pe/agencia/noticia-mas-ong-solicitan-convertirse-edpymes-483428.aspx

Asobancaria, 2015. Microcrédito: buena salud de instrumento de inclusión financiera

Asobancaria,2015. Ley de precios transparentes: una mirada desde la banca.

Banca de las Oportunidades, Superintendencia Financiera de Colombia (2016). Reporte anual de inclusión financiera 2015.

Banco Mundial (2014). Regulaciones Financieras para la inclusión financiera en Paraguay. Nota Técnica.

Banerjee, A. V., Duflo, E., Glennerster, R., \& Kinnan, C. (2013). The miracle of microfinance? Evidence from a randomized evaluation, American Economic Journal: Applied Economics, vol 7(1)

BCB (2016). Relatório de Inclusao Financeira n³, 2015

BCB (2014).Relatório do Plano de Ação para Fortalecimento do Ambiente Institucional, Parceria Nacional para Inclusao Financeira

BCB. O que é sociedade de crédito ao microempreendedor e à empresa de pequeno porte?. Availabe at: http://www.bcb.gov.br/pre/composicao/scmepp.aspf

CLGroup (2009). Regulación y estatuto jurídicos de las entidades de microcrédito en Chile.

Condusef, 2015. Avances y logros de la reforma financiera en materia de protección al usuario. Available at: http://www.gob.mx/condusef/prensa/avancesy-logros-de-la-reforma-financiera-en-materia-deproteccion-al-usuario

Consumer Protection Area (Area de Defensa del Consumidor). Ministry of Finance.

COPEME. Reporte Financiero de Instituciones de Microfinanzas, Marzo 2016.

CPA-Ferrere, "Consultoría Nacional para el Marco Normativo de las Microfinanzas en Uruguay", Ec. Juan Voelker, Junio 2011.

Editorial Observatorio de Inclusión Financiera, 2016. Panorama de las microfinazas y la inclusión financiera en Uruguay. Available at: https://www.microfinancegateway.org/es/library/panorama-de-lasmicrofinanzas-y-la-inclusi $\% \mathrm{C} 3 \% \mathrm{~B} 3 \mathrm{n}$-financiera-en-uruguay

ElEconomista (21/07/2016). Regulación de microcrédito dará certeza a intermediarios: CNBV. Available at: http://eleconomista.com.mx/sistema-financiero/2016/07/21/regulacion-microcredito-dara-certezaintermediarios-cnbv 
ElEconomista (28/06/2016). CNBV afina regulación para el microcrédito. Available at: http://eleconomista.com.mx/sistema-financiero/2016/06/28/cnbv-afina-regulacion-microcredito

ElObservador. 21/06/2016. Defensa al Consumidor: 11\% de denuncias se relacionan a la inclusión financiera.

ElUniversal, 15.06.2016. Condusef recibe 14 mil quejas por despachos de cobranza. Available at: http://www.eluniversal.com.mx/articulo/cartera/finanzas/2016/06/15/condusef-recibe-14-mil-quejaspor-despachos-de-cobranza

Equilibrium, 2015, Análisis del Sistema Microfinanciero Peruano

Fundación Microfinanzas BBVA, 2015. Crédito de consumo de bajo monto en Colombia. Revista Progreso, Número 2. Available at: http://progresomicrofinanzas.org/credito-de-consumo-de-bajo-monto/

Garcia Silveira, M. (2015). Evoluçao da Estructura de microcredito no Brasil. Uma análise sobre o Programa Nacional de Microcredito Productivo Orientado.

Jáuregui, E., Martínez, M. 2014. México: Reforma y grandes retos para las microfinanzas. Available at: https://www.microfinancegateway.org/es/library/m\%C3\%A9xico-reforma-y-grandes-retos-para-lasmicrofinanzas

León, A., Díaz, E., Genta, E. 2012. Estado actual de las Microfinanzas en Uruguay, perspectivas y desarrollo en los países de la región.

Manual de defensa del consumidor en Uruguay.

Marulanda Consultores. 2011. Microfinanzas en México. Elaborado en colaboración con DAI Mexico.

Ministerio de Desarrollo Social, Gobierno de Argentina (2016). Microcréditos. http://www.desarrollosocial.gob.ar/tramitemicrocredito

Ministerio do Trabalho e Emprego, Programa Nacional de Microcredito Productivo Orientado, PNMPO.

Observatorio de Inclusión Financiera (OIF): http://oif.ccee.edu.uy/

Red de desarrollo para las microfinanzas. Informes anuales. http://www.redmicrofinanzas.cl/web/?page id=322

Superintendencia Financiera. Simulador y tarifas de servicios financieros. Tasas de interés activas por modalidad de crédito. Available at:

https://www.superfinanciera.gov.co/isp/loader.jsf?IServicio=Publicaciones\&lTipo=publicaciones\&lFun cion $=$ loadContenidoPublicacion\&id $=61298$

Trujillo-Tejada et al (2015) How is microfinance being regulated in Latin America?

\section{Credit Reporting Systems}

Aguirre and Repetto, 2016. Macroprudential policy evaluation using credit registry data: Argentina, 2009 -

2014. BCRA Economic Research. Available at: https://www.bis.org/events/ccacgdfsconf2016/agenda/argentina pres.pdf

Alternativas Juridicas (2014) Como consultar su historial de credito. Available at: http://www.alternativasjuridicas.com/index.php/noticias/3-newsflash/72-reportado-en-datacredito-Oen-la-cifin

BCB. Sistema de informaçoes de Crédito - SCR- Consulta às Informações do Cliente. 3.0.

http://www.bcb.gov.br/fis/crc/port/SCR_Manual_cidadao.pdf

BCB, 2016. FAQ - Sistema de Informações de Crédito (SCR)

BCU. ¿Qué es la Central de Riesgos Crediticios?. Available at: http://www.bcu.gub.uy/Servicios-Financieros$\underline{\text { SSF/Paginas/Central Riesgos.aspx }}$ 
BCU. Preguntas Frecuentes sobre la Central de Riesgos. http://www.bcu.gub.uy/servicios-financieros$\underline{\text { ssf/paginas/central_riesgos_preguntas.aspx }}$

El Comercio, 2014. Centrales de riesgo: ¿cómo evitar caer en la lista de morosos? Available at: http://elcomercio.pe/economia/peru/centrales-riesgo-como-evitar-caer-lista-morosos-noticia-1740758

Instituto Nacional de Transparencia, Como Ejercer tu Derecho a la Proteccion de los Datos Personales. Available at: http://inicio.inai.org.mx/SitePages/Como-ejercer-tu-derecho-a-proteccion-dedatos.aspx?a $=\mathrm{m} 5$

International Finance Corporation, 2015. Credit Bureaus Around the World

La ley, 2015. Deudores judiciales morosos figurarán en central de riesgos de la SBS. Availablet at: http://laley.pe/not/2125/-deudores-judiciales-morosos-figuraran-en-central-de-riesgos-de-la-sbs/

O Globo (2016). Cinco Maiores Bancos do Brasil Se Unem pelo Cadastro Positivo http://oglobo.globo.com/economia/negocios/cinco-maiores-bancos-do-brasil-se-unem-pelo-cadastropositivo-18513837

O Globo, 2016. Banco Central Vai Passar a Monitorar Operacoes de Credita Acima de R200,Available at: http://g1.globo.com/economia/seu-dinheiro/noticia/2016/03/banco-central-vai-passar-monitoraroperacoes-de-credito-acima-de-r-200.html

SBIF. Sistema de Deudores. Instrucciones Generales. http://www.sbif.cl/sbifweb/internet/archivos/norma 204 1.pdf

SBS. Preguntas frequentes. Available at: http://www.sbs.gob.pe/usuarios/preguntas-frecuentes

Serasa Consumidor, 2016. Protestos. Available at: http://www.serasaconsumidor.com.br/outrosservicos/protestos/

Servicios Integrados de Información S.A., 2016. Portal Ciudadano: Ley 20.575. Available at: https://www.siisa.com/new_home4/form_portal.asp

Valor Economico, 2015. Depois de um Ano e Meio, Cadastro Positivo Nao Avanca, Available at: https://site.cadastropositivo.com.br/depois-de-um-ano-e-meio-cadastro-positivo-nao-avanca/

World Bank, 2011b. Regulation of personal data protection and of reporting agencies. A comparison of selected countries in Latin America, the United States and the European Union.

----------, 2014. Nota técnica. Regulaciones para la inclusión financiera en Paraguay.

--------, 2016c Doing Business 2017: Measuring regulatory quality and efficiency. Country profiles , 2016d. Doing Business 2017: Getting credit.

http://www.doingbusiness.org/data/exploretopics/getting-credit

\section{Simplified KYC Requirements}

Bester, H., et al, 2008, Implementing FATF Standards in Developing Countries and Financial Inclusion: Findings and Guidelines. The FIRST Initiative. The World Bank, Washington, DC

De Koker, L. 2006, "Money laundering control and suppression of financing of terrorism: some thoughts on the impact of customer due diligence measures on financial exclusion", Journal of Financial Crime

Di Castri, S., Grossman, J., Sihin, R. 2015. Proportional risk-based AML/CFT regimes for mobile money. A framework for assessing risks and mitigation measures. GSMA

Durner, T., Shetret, L., 2015, Understanding bank de-risking and its effects on financial inclusion. An explanatory study. Global Center on Cooperative Security

Financial Action Task Force (FATF), 2014. Mutual Evaluation of Mexico. Seventh follow-up report ------------, 2014. Mutual Evaluation of Argentina. Eleventh follow-up report 
2013 Anti-Money Laundering and Terrorist Financing Measures and Financial Inclusion. FATF Guidance

--------------, 2012, International Standards on Combating Money Laundering and the Financing of Terrorism \& Proliferation

Gelb, A. 2016, Balancing Financial Integrity with Financial Inclusion: The risk-based approach to "Know your customer". CGD Policy Paper 074

La Crónica de Hoy, 2016/12/9. Urge la identificación nacional: ABM. Available at: http://www.cronica.com.mx/nacional.php

McGough, C. 2016. Evaluating the impact of AML/CFT regulations: an economic approach. Duke University

Pwc, 2016. Know your customer: quick reference guide

World Bank, 2016. Identification for development (ID4D) global database. Available at: http://data.worldbank.org/data-catalog/id4d-dataset

World Bank, 2014. Regulaciones financieras para la inclusión financiera en Paraguay

\section{Financial Literacy}

Atkinson, A. and F. Messy, 2013, Promoting Financial Inclusion through Financial Education: OECD/INFE Evidence, Policies and Practice, OECD Working Papers on Finance, Insurance and Private Pensions, No. 34

CGAP, 2011, Transferencias de efectivo con fines sociales e inclusión financiera: Experiencias en cuatro países

Garcia, N., Grifoni, A., Lopez, J.C. and Mejía, D., 2013, Financial Education in Latin America and the Caribbean: Rationale, Overview and Way Forward", OECD Working Papers on Finance, Insurance and Private Pensions, No.33

Innovations for Poverty Action, 2017. Beyond the Classroom: Evidence of New Directions in Financial Education. Innovation for Poverty Action Brief

OECD, INFE. 2015. National strategies for financial education. OECD/INFE Policy Handbook

---------, 2012. OECD/ INFE High-Level Principles on National Strategies for Financial Education

OECD. 2005. Recommendation on Principles and Good Practices for Financial Education and Awareness. Recommendation to the Council

Roa, M.J., Alonso, G., García, N., Rodríguez D.A., 2014. Educación e inclusión financieras en América Latina y el Caribe. Programas de los bancos centrales y las superintendencias financieras. CEMLA

\section{Financial Transaction Taxes}

Alburquerque, P., 2001, Os Impactos Econômicos da CPMF: Teoria e Evidência. BCB Trabalhos para Discussao, 21.

Asobancaria, 2014, La Reforma Tributaria es una Talanquera para la Inclusión Financiera. Semana Económica, Edición 976

Baca-Campodónico. J., Mello. L. Kirilenko, A., 2006, The rates and revenue of bank transaction taxes. OECD Working Paper, $\mathrm{n}^{\circ} 494$.

Beitler, D., 2010, Raising revenue. A review of Financial Transaction Taxes throughout the world.

Brasil Economico. (11/07/2016). Arrecadação da CPMF só entra no Orçamento 2017 com PEC aprovada até dezembro. Available at: http://economia.ig.com.br/2016-07-11/cpmf-imposto-cheque-ldo.html 
--. (13/05/2016). Meirelles deixa em aberto um eventual retorno da CPMF. Available at:

http://economia.ig.com.br/2016-05-13/meirelles-deixa-em-aberto-um-eventual-retorno-da-cpmf.html

Coelho, I., Ebrill, L., Summers, V., 2001, Bank Debit Taxes in Latin America: an analysis of recent trends.

IMF Working Paper.

Comisión de Expertos para la Equidad y Competitividad Tributaria, 2015, Informe Final presentado al Ministerio de Hacienda y Crédito Público

Financial Times, 2013, Brazil slashes financial transactions tax. Available at: https://www.ft.com/content/6c113a7c-cd74-11e2-90e8-00144feab7de

G1 Globo, 20/01/2015. Veja simulações dos efeitos da alta do IOF sobre o crédito ao consumidor. Available at: http://g1.globo.com/economia/seu-dinheiro/noticia/2015/01/veja-simulacoes-dos-efeitos-da-altado-iof-sobre-o-credito-ao-consumidor.html

Koyama, S., Nakane, M., 2001, Os Efeitos da CPMF sobre a Intermediação Financeira. BCB Trabalhos para Discussao, 23.

Larraín, C., 2006, Obstáculos para el Acceso a Servicios Financieros en Chile. Prepared for the General IberoAmerican Secretariat (SEGIB)

Lozano-Espitia, I., Rodriguez-Niño, N., Vargas-Herrera, H. Financial Transaction Tax and Banking Margins: An Empirical Note for Colombia. Banco de la Republica, Borradores de Economía, No 909.

Macedo, Roberto (31/08/2016). CPMF mais uma vez? O Povo online. Available at: http://www.opovo.com.br/app/opovo/opiniao/2016/08/31/noticiasjornalopiniao,3654566/cpmfmais-uma-vez.shtml

O Globo, 03/01/2008. Novo IOF vai pesar mais sobre crédito que CPMF. Available at: http://oglobo.globo.com/economia/novo-iof-vai-pesar-mais-sobre-credito-que-cpmf$\underline{3638304 \# \text { ixzz4Kn0cQHOY }}$

Penido do Freitas, M.C., Cagnin, R., 2013, Tributaçao das transaçoes financeiras: a experiencia brasileria com o IOF e a CPMF. CEPAL/IPEA

Portal Brasil (21/09/2015). Febraban: "medidas melhoram confiança e CPMF facilita reequilíbrio fiscal". Available at: http://www.brasil.gov.br/economia-e-emprego/2015/09/febraban-medidas-melhoramconfianca-dos-agentes-economicos-e-cpmf-facilita-reequilibrio-fiscal

Ruiz Álvarez, J.C., 2012, El Impuesto a los Depósitos en Efectivo (IDE): ¿Un incentivo a la informalidad. Centro de Estudios de las Finanzas Públicas, Cámara de Diputados del Congreso de la Unión.

Singh, A., Belaisch, A., Collyns, C., Masi, P., Krieger, R., Meredith, G., Rennhack, R., 2005, Stabilization and Reform in Latin America: A Macroeconomic Perspective on the Experience Since the Early 1990s. IMF Occasional Paper 238

Valero, H. J., 2007, Generalidades del Gravamen a los Movimientos Financieros (GMF) en Colombia. Oficina de Estudios Económicos, Dirección de Impuestos y Aduanas Nacionales.

\section{Interest Rate Ceilings}

Asobancaria. 18 agosto 2016. ¿Cuál es la tasa de usura actual? Available at: http://www.asobancaria.com/sabermassermas/cual-es-la-tasa-de-usura-actual/

Asociación de Bancos e Instituciones Financieras (2016). "Tasa máxima convencional y crédito de consumo," Serie Abif Informa $N^{\circ} 77$. (19 de mayo de 2016)

Castellanos, S. (2012). Interest rate caps: back to the future in LatAm? BBVA Research Watch

Clavijo et al. (2015). Regulación Bancaria: Sus costos y efectos sobre la bancarización. Asociación Nacional de Instituciones Financieras, Centro de Estudios Económicos. 
Fedesarrollo, 2012, Efectos y consecuencias del sistema de cálculo aplicado a las tasas de referencia y la determinación de la tasa de usura. FEDESARROLLO para el Programa de Políticas Publicas de USAID. Revisado por Ministerio de Hacienda y Crédito Público.

LaNación. (28/06/2016). Se eliminaron casi 71.000 tarjetas de crédito a mayo. Disponible en: http://www.lanacion.com.py/2016/06/28/se-eliminaron-casi-71-000-tarjetas-de-credito-a-mayo/

SBIF (2015). "Primer informe anual sobre los efectos de la aplicación de la Ley $\mathrm{N}^{\circ}$ 20.715," Documentos SBIF, 31 de marzo de 2015.

SBIF (2016). "Segundo informe anual sobre los efectos de la aplicación de la Ley N²0.715," Documentos SBIF, 4 de marzo de 2018.

Voelker, Juan, 2011 "Consultoría Nacional para el Marco Normativo de las Microfinanzas en Uruguay", CPA-Ferrere, Junio.

World Bank (2014) Regulaciones financieras para la inclusión financiera en Paraguay. Nota Técnica

\section{Directed Lending}

Asobancaria, 2014. Una mirada al crédito agropecuario. Semana Económica Edición 974

Banco Mundial (2014). Evaluación del lado de la oferta de la inclusión financiera en Paraguay. Nota Técnica Comisión Nacional de Banca y Valores, 2016, Reporte Nacional de Inclusión Financiera 7.

------, CNBV. Notas relevantes sobre la banca de desarrollo. Internet article available at: http://www.gob.mx/cnbv/acciones-y-programas/notas-relevantes-sobre-la-banca-de-desarrollo

El Mundo. 13/10/2014. El agro, entre la inversión forzosa y la cartera sustitutiva. Available at: http://www.elmundo.com/portal/noticias/economia/el agro entre la inversion forzosa y la carter a sustitutiva.php\#.V-upa mLSM8

FELABAN, 2013, Encuesta con información recopilada sobre el tratamiento de la banca estatal.

Held, G., Jimenez, L.P., 1999, Liberalización financiera, crisis y reforma del sistema bancario chileno: 19741999. Cepal.

IMF, 2013, Financial Sector Assessment Program Report on Uruguay.

-------, 2013. Financial Sector Assessment Program, Uruguay

OECD, 2016, Colombia: Review of the Financial System

Santos, F. K. (2016). Earmarked credit and misallocation: evidence from Brazil. Universidade de São Paulo World Bank, 2014, Financial Regulations for financial inclusion in Paraguay. Technical Note. 


\section{Annex I: Sub-Indices Indicators-Definitions and Scoring Methodology}

\section{I.A. Competition Policies}

The Competition Policies sub-index is made up of 4 indicators. Some of the indicators have two or three components. In that case, the score for the indicator is obtained as a simple average of the components' scores. The four indicators are then aggregated to obtain the final score, for which all indicators are equally weighted. Each indicator and its components obtained a value in the 0-2 range, with higher values representing a more enabling competition framework. An indicator/component may not apply to a particular country, in which case it is marked as n.a. (not applicable). This does not affect the aggregated score which is calculated by averaging the available indicator scores.

The four indicators and the scoring criteria are defined as follows:

\section{Market Entry}

\section{Component A. Foreign bank restrictions}

Description. It measures whether there are legal impediments to a foreign bank entering, operating in or exiting from a country's financial system.

Scoring.

2: Foreign banks are explicitly allowed to enter the country's banking system by establishing a branch or a subsidiary and no additional restrictions are imposed for their establishment, operation or exit.

1: There are legal impediments to foreign financial institutions entering, operating or exiting the country's banking system. For instance, in Brazil foreign banks are barred by the regulation from entering the country's banking system. Authorisation can only be obtained through Presidential approval.

0: Foreign banks cannot enter and operate in a country's banking system.

\section{Component B. State-bank ownership}

Description. An indicator that looks for the existence of legislative provisions on state-owned banks that might generate a crowding out effect on private banks, affecting competition.

Scoring.

2: There are no significant differences regarding supervision and regulation between public and private banks, and there is no evidence of a lack of a level playing field between public and private banks.

1: There are some differences regarding supervision and regulation between public and private banks or there is some evidence of lack of a level playing field.

0: There is evidence of a significant monopolistic power for a public bank. 


\section{Component C. Entry of digital financial services providers}

Description. Competition in a country's financial sector can benefit from allowing the entry of nonbank digital financial service providers (DSPs). In the case of DSPs that restrict their activities to transactional services or that offer stores of value fully backed by safe assets, entry requirements should be relatively minimal, with an option for ex post regulatory intervention as the market evolves and new risks arise. For the purposes of this exercise, we have looked at the rules governing the entry into the market of non-bank electronic money issuers.

Scoring.

2: Digital services providers (non-bank e-money issuers) are allowed to enter the market and provide financial services. For DSPs that restrict their activities to transactional services or that offer stores of value fully backed by safe assets, the requirements for entry are minimal and only focus on ensuring that the DSP has adequate technical and operational capabilities.

1: Digital services providers are allowed to enter the market and provide some financial services. However, for DSPs that restrict their activities to transactional services or that offer stores of value fully backed by safe assets, the requirements for entry are highly restrictive.

0: Digital service providers are not allowed to enter the market.

\section{Market exit}

Description. An indicator that measures whether existing laws and regulations ensure that providers which are no longer viable exit the market.

\section{Component A. Market exit rules for banks}

Description: There should be specific rules for dealing with bank failures, beyond commercial bankruptcy laws. Scoring:

2: There are comprehensive rules for dealing with bank failures, beyond commercial bankruptcy laws, and they are implemented.

0: There are no specific rules for dealing with bank failures beyond commercial bankruptcy laws.

\section{Market exit for banks adjusted for alignment with international standards}

Description. We introduce an adjustment that considers whether the country's bank resolution framework is aligned with international standards, as provided for in the FSB's Key Attributes for Effective Resolution Regimes.

Scoring. For countries that score 2 in Component a. we subtract 0.5 when one of the following conditions is met and $1(0.5+0.5)$, when the following two conditions are met:

- The country's resolution framework lacks sufficient resolution powers and tools. This powers 
and tools include the following: transfer of all or part of the business either to another financial institution or to a bridge institution, bail-in and liquidation procedure

- The authorities do not require the elaboration of recovery and resolution plans ${ }^{78}$ for systemic banks.

\section{Component B. Market exit rules for digital financial services providers}

Description: An indicator that measures if the laws and regulations on non-bank e-money issuers provide clear rules that allow the exit of market participants which are no longer viable.

Scoring:

2: Market exit rules for DSPs, such as e-money issuers, that restrict their activities to small payments and transfers and fully backed stores of value follow commercial bankruptcy laws, while providing some safeguards for the customers' funds.

0: There are no clearly defined rules for the exit of DSPs, or these rules are the same as those imposed on banks.

\section{Potential abuses of market power}

Description. This indicator measures the soundness of antitrust rules and their capacity to avoid the emergence of entities with excessive market power.

Scoring.

2: Antitrust rules, powers and enforcement capacity in place are sufficient to prevent potential abuses of market power in the financial sector.

1: Antitrust rules, powers and enforcement capacity are in place but may not always be sufficient to prevent potential abuses of market power in the financial sector.

0: Antitrust rules, powers and enforcement capacity are not in place.

\section{Contestability of inputs and interoperability}

Description. This indicator measures the extent to which different types of financial services providers have access on the same terms to the critical networks and inputs on which the provision of their services depends (i.e. inputs can be accessed at competitive prices and efficiently distributed). Also, it measures the degree of interoperability in financial services, such that users of any network can transact with customers of any other network. Interoperability ideally emerges as a market solution, but there may be cases when, to prevent entrenchment of monopoly/oligopoly powers, regulatory intervention may be needed. Thus, although interoperability should not be mandated from the inception to avoid unnecessarily constraining the market,

\footnotetext{
78: A key component of the financial regulatory framework introduced after the crisis is the requirement for major banks to prepare and implement living wills or recovery and resolution plans as referred to in the FSB's Key Attributes. These plans are written documents that must outline how banks would regain viability if they are under severe financial pressure and the steps the local regulators will take if, despite these steps, the institutions fail.
} 
regulatory intervention may be necessary once the regulator assesses that the market has reached a sustainable degree of development, since lack of interoperability might be an indicator of competition problems not addressed by the regulator (Claessens and Rojas-Suarez, 2016). The following inputs were considered:

\section{Component A. Interoperability of ATMs}

Scoring.

2: There is no evidence of lack of interoperability, related to competition problems, that could require government intervention.

0 : There is evidence of lack of interoperability, signalling competition problems, that could require government intervention.

\section{Component B. Contestability and interoperability of agents}

Scoring.

2: The regulation in place requires that systems and necessary infrastructure for the operation of agents' networks have the capacity to become interoperable, but does not prohibit exclusivity of agents.

1: The regulation in place does not deal with the interoperability of agents' networks.

0: Exclusivity is explicitly prohibited in the regulation OR the regulatory framework in place does not allow other institutions other than banks to operate through agents.

\section{Component C. Contestability and interoperability of credit reporting systems}

Scoring.

2: Banks and financial institutions are allowed to access borrowers credit information stored in existing credit bureaus or credit registries.

0 : The law is silent regarding the ability of banks and financial institutions to access borrowers' credit information stored in existing credit bureaus or credit registries.

\section{I.B Supervisory Quality}

The Supervisory Quality sub-index is made up of two indicators. The first indicator has eleven components while the second indicator has a single component. The two indicators are then aggregated with equal weights to obtain the final score. Each indicator and its components obtained a value in the $0-2$ range, with higher values representing a more enabling supervisory framework. 


\section{Supervisory Powers}

Description. This indicator strictly mirrors the index of official supervisory power from Barth, Caprio and Levine $(2005,2013)$ and therefore measures the degree to which a country's bank supervisory agency has the authority to take specific actions.

For the purposes of comparison and consistency with the rest of the paper, the scores presented are not necessarily in their original scale. When necessary, they have been rescaled to the $0-2$ range. Originally, the scores in Barth, Caprio and Levine (2013) were 0 or 1 for relevant questions in Components A to H, and 0 , 0.5 or 1 for Components I, J and $\mathrm{K}$. The score for the indicator is calculated using the following formula from Barth et. al. (2013).

Supervisory powers indicator score $=\left(A+B+C+D+E+F+G+H^{* 2}+I+J * 2+K^{* 2}\right) / 14{ }^{79}$

For further information on these scores and on the aggregation of the supervisory power index, please refer to Annex III.

\section{Component A. Meeting with external auditors}

Scoring.

2: The banking supervisor has the right to meet with the external auditors and discuss their report without the approval of the bank.

0: The banking supervisor does not have the right to meet with the external auditors and discuss their report without the approval of the bank.

\section{Component B. Be informed about illicit activities, fraud, insider abuse}

Scoring.

2: Auditors are required to communicate directly to the supervisory agency any presumed involvement of bank directors or senior managers in illicit activities, fraud, or insider abuse.

0: Auditors are not required to communicate directly to the supervisory agency any presumed involvement of bank directors or senior managers in illicit activities, fraud, or insider abuse

\section{Component C. Act against external auditors}

Scoring.

\footnotetext{
${ }^{79}$ Barth, Caprio and Levine (2013) assign a larger weight to some of the questions in the construction of the Official Supervisory Powers index. This is done by multiplying some surveys by two. This explains why Components H, J and K in our Supervisory powers indicator are also multiplied by two.
} 
2: The supervisor has the powers to take actions against the external auditor in cases where the supervisor identifies that the bank has received an inadequate audit.

0: The supervisor does not have the powers to take actions against the external auditor in cases where the supervisor identifies that the bank has received an inadequate audit.

\section{Component D. Change organisational structure of banks}

Scoring.

2: The supervisory authority can force a bank to change its internal organisational structure.

0: The supervisory authority cannot force a bank to change its internal organisational structure.

\section{Component E. Disclosure of off-balance sheet items}

Scoring.

2: Off-balance-sheet items are disclosed to supervisors.

0: Off-balance-sheet items are not disclosed to supervisors.

\section{Component F. Impose provisioning requirements}

Scoring.

2: The supervisory agency can require banks to constitute provisions to cover actual or potential losses.

0: The supervisory agency cannot require banks to constitute provisions to cover actual or potential losses.

\section{Component G. Suspend dividends}

Scoring.

2: The supervisory agency can require banks to reduce or suspend dividends to shareholders

0: The supervisory agency cannot require banks to reduce or suspend dividends to shareholders

\section{Component $\mathbf{H}$. Suspend bonuses and management fees}

Scoring.

2: The supervisory agency can require banks to reduce or suspend bonuses and other remuneration to bank directors and managers.

0: The supervisory agency cannot require banks to reduce bonuses and other remuneration to bank directors and managers. 


\section{Component I. Declare bank insolvency}

Scoring.

2: The banking supervisor has the power to declare bank insolvency.

1: The deposit insurance agency or a bank restructuring or asset management agency have the power to declare bank insolvency.

0: None of the above have the power to declare a bank insolvency

\section{Component J. Supersede shareholders' rights}

Scoring.

2: The banking supervisor has the power to supersede shareholders' rights.

1: The deposit insurance agency or a bank restructuring or asset management agency have the power to supersede shareholders' rights.

0: None of the above have the power to supersede shareholders' rights.

\section{Component K. Replace managers and directors}

Scoring.

2: The banking supervisor has the power to remove and replace managers and directors.

1: The deposit insurance agency or a bank restructuring or asset management agency have the power to remove and replace managers and directors.

0 : None of the above have the power to remove and replace managers and directors.

\section{Independence of the supervisor}

Description. This indicator tries to assess the degree to which the supervisory authority is independent from political influence and the degree to which the supervisory authority is able to make decisions independently of political considerations. For the purposes of providing reliable, objective and up-to-date information on the independence of the supervisor, we use question 2.1.2 from the latest available EIU Global Microscope.

Scoring.

2: The financial regulator is always independent of political influence.

1: The financial regulator is generally independent of political influence.

0: The financial regulator is often influenced by political dynamics. 


\section{I.C. Simplified Accounts}

This sub-index is made up of two sets of indicators: minimum regulatory standards and additional government efforts. The score for the first set, made up of 8 indicators, is obtained as a simple average of the scores for the indicators (with indicator $8 \mathrm{a}$, adjusted fees and commissions, rather than the unadjusted indicator 8 , being the relevant indicator included). The score for the second set equals the score of the indicator adjusted additional government efforts. To obtain the overall score for the sub-index, we have attached a weighting of 0.6 to the score for the first set and a weighting of 0.4 to the score for the second set. These weightings are arbitrary and alternative exercises can (and should) be conducted. The higher weighting attached to the first set simply reflects our perception that a well-designed regulatory framework for these accounts has the potential to go a long way towards improving financial inclusion, even if additional government efforts are not in place.

The indicators included in the two sets and the scoring criteria are as follows:

\section{$\underline{\text { Minimum regulatory standards }}$}

\section{Regulatory framework}

Scoring.

2: There is a dedicated regulatory framework for simplified accounts.

0: Simplified accounts are not a regulated product in the country.

\section{Clients}

Scoring.

2: Simplified accounts are available for individuals and small firms.

0: Simplified accounts are not available for small firms.

\section{Providers}

Scoring.

2: The product can be offered by all financial institutions that are authorised to take deposits, provided the regulatory framework allows for a level playing field among them.

1: The product can be offered by non-bank institutions, but not by all financial institutions that can take deposits.

$0:$ The product can only be offered by banks.

\section{Permitted channels for the provision of simplified accounts.}

Scoring.

2: The product can be offered and managed through banking correspondents and other digital means. 
1: The product can be offered through banking correspondents but not by non-bank digital means. However, the product can be managed through banking correspondents and/or other banks' digital means, such as mobile banking.

0: The product can neither be offered nor managed through banking correspondents or other forms of digital means.

\section{Identification and verification requirements for the provision of simplified accounts.}

Scoring.

2: Provision of simplified accounts falls under a simplified KYC regime. Identification and verification requirements are minimal, aiming to identify the account holder only, and are accessible for every individual (they do not involve proof of address, payment of utility bills or sources of income).

1: Provision of simplified accounts falls under a simplified KYC regime. However, identification and verification requirements are not truly minimal and could limit financial inclusion (information requirements are too restrictive or a significant percentage of the target population does not have access to the required documents).

0: Provision of simplified accounts is not subject to a simplified KYC regime OR regulations in place do not address this issue.

\section{Transactional limits.}

Scoring.

2: There are clear limits to the account balance (consistent with the income levels of poor populations) and to the monetary value of the transactions (deposits and withdrawals). Balances or transactions above the limit might lead to a graduation to a more complex account (or a regular account), provided additional due diligence requirements are fulfilled.

1: There are clear limits to the account balance (consistent with the income levels of poor populations) and to the monetary value of the transactions (deposits and withdrawals). Balances or transactions above the limit lead to the closure of the account.

0: Transactional limits are not defined or are too restrictive.

\section{Limits to number of accounts.}

\section{Scoring.}

2: Limits to the number of accounts held by an individual are set at the entity level, or are set at the system level and there is a platform or other mechanism in place in the country that allows providers to easily verify the number of simplified accounts an individual already holds.

1: Limits to the number of accounts held by an individual are set at system level and there is no platform or other mechanism in place in the country that allows providers to easily verify the number of simplified accounts an individual already holds. 
0: The number of accounts an individual can hold is not limited in the regulation.

\section{Fees and commissions}

Scoring.

2: There are no restrictions to fees and commissions for opening or maintaining simplified accounts or undertaking transactions that limit providers' ability to design viable products.

0: There are significant restrictions to fees and commissions for opening and maintaining simplified accounts that limit providers' ability to design viable products.

\section{- 8.a Adjusted Fees and commissions (for quality of competition policies)}

Scoring

2: There are no restrictions on fees and commissions for opening or maintaining simplified accounts or undertaking transactions that limit providers' ability to design viable products AND the sub-index on Competition Policies has a value greater than or equal to 1 ;

1: There are restrictions on fees and commissions for opening and maintaining simplified accounts that limit providers' ability to design viable products AND the sub-index on Competition Policies has a value lower than 1

0 : There are no restrictions on fees and commissions for opening or maintaining simplified accounts or undertaking transactions that limit providers' ability to design viable products AND the sub-index on Competition Policies has a value lower than 1;

0: There are significant restrictions on fees and commissions for opening and maintaining simplified accounts that limit providers' ability to design viable products AND the sub-index on Competition Policies has a value greater than or equal to 1

\section{Additional government efforts}

\section{Additional government efforts}

Scoring.

2: The government has implemented additional efforts to induce usage of simplified accounts, and these efforts reach both the formal and informal sector.

1: The government has implemented additional efforts to induce usage of simplified accounts, but these efforts have only reached the formal sector.

0: The government has not implemented additional efforts to induce usage of simplified accounts.

\section{- 1.a Adjusted additional government efforts (for crowding out)}

Description. Additional efforts by the government to promote usage of simplified accounts should not generate distortions or disincentives, by crowding out other financial services or institutions. 
Scoring.

2: The government has implemented additional efforts to induce usage of simplified accounts, and these efforts reach both the formal and informal sector AND no crowding out of other financial services or institutions has been identified.

1: The government has implemented additional efforts to induce usage of simplified accounts, but these efforts have only reached the formal sector AND no crowding out of other financial services or institutions has been identified.

0.5: The government has implemented additional efforts to induce usage of simplified accounts, and these efforts reach both the formal and informal sector AND crowding out of other financial services or institutions has been identified

0 : The government has implemented additional efforts to induce usage of simplified accounts, but these efforts have only reached the formal sector AND crowding out of other financial services or institutions has been identified

0: The government has not implemented any additional efforts to induce usage of simplified accounts.

\section{I.D. Electronic Money}

This sub-index is formed by two sets of indicators: minimum regulatory standards and additional government efforts. The score for the first set, made up of 8 indicators, is obtained as a simple average of the scores for the indicator (with indicator $8 \mathrm{a}$, adjusted fees and commissions, rather than the unadjusted indicator 8 , being the relevant indicator included). The score for the second set equals the score of the indicator adjusted

additional government efforts. To obtain the overall score for the sub-index, we have attached a weighting of 0.6 to the score for the first set and a weighting of 0.4 to the score for the second set. These weightings are arbitrary and alternative exercises can (and should) be conducted. The higher weighting attached to the first set simply reflects our perception that a well-designed regulatory framework for electronic money has the potential to go a long way towards improving financial inclusion, even if additional government efforts are not in place.

The indicators included in the two sets and the scoring criteria are as follows:

\section{$\underline{\text { Minimum regulatory standards }}$}

\section{Regulatory Framework}

Description: The indicator assesses whether there is regulation allowing for the provision of electronic money Scoring.

2: There is a dedicated regulatory framework for electronic money.

0: Electronic money is not regulated in the country.

\section{Providers}


Description. In order to fully exploit the potential of electronic money to advance financial inclusion, regulators should create a level playing field that allows both banks and non-bank providers to offer electronic money services. To guarantee financial stability, integrity and adequate consumer protection, the financial supervisor should conduct the oversight of electronic money providers by: (i) directly licensing the non-bank, (ii) requiring the non-bank to apply for an electronic money or payments banks licence, or (iii) requiring the nonbank to set up a subsidiary.

Scoring.

2: The regulatory framework effectively permits both banks and non-banks to compete on a level playing field in the provision of electronic money. Both banks and non-banks are under the supervision of the financial regulator.

1: The regulatory framework permits both banks and non-banks to issue electronic money, but there are provisions in the regulation that hinder the establishment of a level playing field.

0: Electronic money provision is limited to banks.

\section{Delimitation of activity}

Description. The regulatory framework should provide that all funds held by electronic money issuers (the socalled e-float) can be converted into cash. Therefore, the regulatory framework prevents electronic money issuers from intermediating the funds through lending. This way, funds are not subject to credit, market or liquidity risk and the business can be regulated differently than that of a credit-issuing institution (a bank).

Scoring. 2: Financial intermediation is prohibited, and therefore the electronic money issuer cannot grant credit.

0: Financial intermediation is permitted, and therefore the electronic money issuer can grant credit.

\section{Identification and verification requirements for the provision of electronic money}

Description. There should be appropriate KYC requirements to protect against the risk of money laundering and terrorist financing without unnecessarily restricting access to electronic money services for unbanked consumers.

Scoring.

2: A simplified KYC regime is allowed for the provision of electronic money, subject to appropriate limits to the balance and/or volume of transactions. Under this regime, identification and verification requirements are minimal and accessible for every individual (they do not involve proof of address, payment of utility bills or sources of income).

1: A simplified KYC regime is allowed for the provision of electronic money, subject to appropriate limits to the balance and/or volume of transactions. However, identification and verification requirements are not truly minimal and might limit financial inclusion (information requirements are too restrictive or a significant percentage of the target population does not have access to the required documents). 
0: Provision of e-money for low balance accounts is not subject to a simplified KYC regime OR the regulation in place does not address this issue.

\section{Use of agents}

Description. Regulation should enable electronic money providers to expand their reach through the use of third-party agents. However, they should retain accountability for the quality and soundness of the agents, safeguard customer funds held by agents and ensure that they maintain adequate liquidity to properly serve customers.

Scoring.

2: Electronic money providers have sufficient flexibility in choosing agents and outsourcing services. Services that can be outsourced include, at least, cash-in/cash-out and the full process of affiliation to an electronic money product. Providers retain accountability for the agents' operations.

1: Electronic money providers can outsource services though agents, but the process of affiliation cannot be completed by an agent (agents are only allowed to send and receive information and documentation). Providers retain accountability for the agents' operations.

0 : Electronic money providers cannot outsource services through agents OR the regulation in place does not address this issue.

\section{Protection of funds}

Description. An enabling regulatory framework must allow for the provision of electronic money by banks and non-banks, provided appropriate mechanisms are in place to safeguard consumers' funds. Although the ultimate decision will most likely be country-specific, customer funds are deemed to be effectively safeguarded when the following three conditions are met: (i) the electronic money provider can meet customers' demands for cash, (ii) customer funds are protected against the issuer's insolvency and (iii) customer funds are protected against insolvency of the bank in which the funds are deposited.

This translates into the following three components:

\section{Component A. Liquidity requirements}

Scoring.

2: Regulation requires providers to set aside funds equal to 100 percent of outstanding electronic money liabilities in safe and liquid investments (such as bank accounts, government bonds or other investments) in order to ensure that the mobile money provider can meet customers' demands for cash.

0 : This provision is not contemplated in the regulation in place. 


\section{Component B. Protection against issuer's insolvency}

Scoring.

2: Regulation requires e-money issuers to establish a ring-fencing mechanism (trust, fiduciary contract or other available mechanism ${ }^{80}$ ) to segregate customer funds.

0 : The regulation in place does not include any specific provision on ring-fencing of customer funds

\section{Component C. Protection against bank's insolvency}

Scoring.

2: Funds are safeguarded in case of insolvency of the bank, by using one or a combination of the following options:

a. Providing deposit insurance to the individual electronic money accounts (directly or through a passthrough regime ${ }^{81}$ ), if deemed feasible and cost-effective

b. Private insurance, in countries where the insurance market is sufficiently developed.

c. Monitoring the strength of the bank holding the funds

d. Requirements to diversify customer funds across multiple banks

e. Initial and on-going capital requirements. This should be proportionate in order not to unnecessarily limit innovation. There is no consensus regarding the appropriate level of minimum initial capital requirement. Regarding ongoing capital requirements, international experience points to a range between 2 and 3 percent.

0 : The regulation in place does not include any specific provision to safeguard customer funds against insolvency of the bank in which the funds are placed.

\section{Interoperability}

Description. Interoperability implies the ability of users of one network to transact with users of another network, which can be achieved at different levels—at the customer level, at the agent level or at the platform level. Regulatory intervention to ensure interoperability, if deemed necessary, should not be mandated from inception, in order not to unnecessarily constrain the market.

\section{Scoring.}

2: The regulation does not mandate the implementation of a specific interoperability model but requires that systems and necessary infrastructure have the capacity to become interoperable.

\footnotetext{
${ }^{80}$ : The selection of the legal mechanism will mostly depend on the country's legal system, and whether it is most influenced by common law or civil law.

81: Pass-through deposit insurance is defined as coverage for the ultimate retail customer instead of an intermediary. Therefore, in jurisdictions where pass-through deposit insurance is recognised, the deposit insurance provider acknowledges that under certain circumstances, funds that are combined and held in a single account may be better characterised as a number of smaller accounts for the purposes of deposit insurance. See IADI (2013).
} 
1: The regulation does not include any provisions related to interoperability.

0 : The interoperability mandate in the regulation constrains the development of the market OR the market for electronic money remains non-interoperable once it is highly developed, but no regulatory action has been undertaken to encourage interoperability.

\section{Fees and commissions}

Scoring.

2: There are no restrictions to fees and commissions for opening or maintaining electronic money products or undertaking transactions that limit providers' ability to design viable products.

0: There are significant restrictions to fees and commissions for opening and maintaining electronic money products that limit providers' ability to design viable products.

\section{- 8.a Adjusted fees and commissions (for quality of Competition Policies)}

Scoring

2: There are no restrictions on fees and commissions for opening or maintaining electronic money products or undertaking transactions that limit providers' ability to design viable products AND the sub-index on Competition Policies has a value greater than or equal to 1 ;

1: There are restrictions on fees and commissions for opening and maintaining electronic money products that limit providers' ability to design viable products AND the sub-index on Competition Policies has a value lower than 1

0: There are no restrictions on fees and commissions for opening or maintaining electronic money accounts or undertaking transactions that limit providers' ability to design viable products AND the sub-index on Competition Policies has a value lower than 1;

0: There are significant restrictions on fees and commissions for opening and maintaining electronic money accounts that limit providers' ability to design viable products AND the sub-index on Competition Policies has a value greater than or equal to 1 .

\section{$\underline{\text { Additional government efforts }}$}

\section{Additional government efforts}

Description: This indicator aims to assess whether the government has implemented additional efforts to induce usage of electronic money. These additional efforts include (but are not restricted to) payment of conditional transfers, wages, pensions and other forms of remuneration, beneficial fiscal transfer and promotion of usage by individuals and small firms. Ideally, these additional efforts should capture people from both the formal and the informal sector. 
Scoring.

2: The government has implemented additional efforts to induce usage of electronic money products, and these efforts reach both the formal and informal sector.

1: The government has implemented additional efforts to induce usage of electronic money products, but these efforts have only reached the formal sector.

0: The government has not implemented additional efforts to induce usage of electronic money products.

\section{- 1.a Adjusted additional government efforts (for crowding out)}

Scoring

2: The government has implemented additional efforts to induce usage of electronic money products, and these efforts reach both the formal and informal sector AND no crowding out of other financial services or institutions has been identified.

1: The government has implemented additional efforts to induce usage of electronic money products, but these efforts have only reached the formal sector AND no crowding out of other financial services or institutions has been identified.

0.5: The government has implemented additional efforts to induce usage of electronic money products, and these efforts reach both the formal and informal sector AND crowding out of other financial services or institutions has been identified

0 : The government has implemented additional efforts to induce usage of electronic money products, but these efforts have only reached the formal sector AND crowding out of other financial services or institutions has been identified

0: The government has not implemented additional efforts to induce usage of electronic money products.

\section{I.E. Correspondents}

The Correspondents sub-index is made up of 9 indicators. Some of the indicators have several components. In that case, the score for the indicator is obtained as a simple average of the components' scores. The value of the indicator on fees and commissions (indicator 9) is the weighted average of its components 9.A and 9.B.a, the latter to incorporate the adjustment for the quality of competition policies. Component 9.A. receives a weighting of 0.4 and component 9.B.a receives a weighting of 0.6. The higher weighting attached to 9.B.a is due to the importance to financial inclusion of regulations on fees and commissions charged to customers (by financial institutions and their correspondents)

Each indicator and its components obtained a value in the $0-2$ range, with higher values representing a more favourable framework. The indicators are then aggregated to obtain the final score, for which all indicators are equally weighted. 
If the correspondents' business model is not regulated and/or implemented in one country (therefore receiving a score of 0 in the first indicator), the rest of the indicators are qualified as not applicable (n.a.)

The definition of the indicators and the scoring criteria are as follows:

\section{Regulatory framework}

Description. The indicator assesses whether there is regulation in place to allow financial services providers to operate through agents and whether in addition to banks, other types of financial institutions (such as credit cooperatives, microfinance institutions) and other institutions authorised by the relevant authority (Central Bank or supervisory authority) to offer financial services (such as electronic money providers) are considered for authorisation to engage in agents' networks.

Scoring.

2: There is a framework in place to regulate operations by financial institutions through correspondents AND it applies to banks, other financial institutions (such as credit cooperatives or microfinance institutions) and other institutions authorised to offer financial services (e-money providers).

1: There is a framework in place to regulate operations by financial institutions through correspondents, BUT it does not apply to financial institutions other than banks (such as credit cooperatives or microfinance institutions) or other institutions authorised to offer financial services (e-money providers).

0 : There is no framework in place to regulate operations by financial institutions through correspondents

\section{Accountability}

Description. This indicator refers to the regulatory imposition on the contracting financial institutions of the liability for the agents' actions.

Scoring. 2: Regulation imposes full liability on financial institutions for all of the agents' actions and compliance with relevant regulation. 1: Financial institutions retain partial liability for the agents' actions. 0: Financial institutions do not retain accountability for the agents' action.

\section{Business models}

Description. The indicator assesses regulatory provisions that determine the potential reach of the network of correspondents, as a function of the types of establishments allowed, requirements related to the formality of the establishment (being incorporated as a company or registered in the fiscal census), restrictions in terms of location and the different management models allowed.

\section{Component A. Types of establishments allowed}

Description. The widespread recommendation is to limit restrictions to the range of agents allowed, avoid unnecessary formality requirements and location restrictions provided that financial institutions retain accountability for the financial services offered through the correspondents. Restricting the involvement of actors who may be the most promising agents due to their existing network, their location in underserved areas and/or their capacity to manage decentralised operations (such as savings and credit cooperatives, for example) should be avoided. 
Scoring.

2: Any establishment whose legal regime allows it to serve the public can serve as a correspondent, provided that financial institutions retain accountability for the financial services offered through the correspondents.

1: Any establishment whose legal regime allows it to serve the public can serve as a correspondent, except when its main business is providing financial services. Financial institutions retain accountability for the financial services offered through the correspondents.

0: Significant restrictions to the types of establishments allowed hinder the involvement of actors who may be valuable agents.

\section{Component B. Management of the network}

Description. Administrators of correspondents are widely identified as an essential element for the development of extensive networks of agents. This is an indirect management model, which can take many forms, although typically administrators participate in the selection, contracting and training of agents, as well as providing technical assistance. This figure reduces the cost of setting up an agent network for the contracting financial institution (CGAP, 2011a; CNBV, 2011). Thus, financial inclusion goals might benefit from regulation that allows an indirect management model, provided that financial institutions retain the responsibility for the financial services offered through the correspondents.

Scoring. 2: Financial institutions are allowed to operate through a network administrator AND financial institutions retain the responsibility for the financial services offered through the correspondents.

1: The regulation does not deal with this issue.

0: Financial institutions are not allowed to operate through a network administrator, OR they are allowed to do so without bearing the ultimate responsibility for the financial services offered through the correspondents.

\section{Permitted activities}

Description. This indicator captures the products and services that financial institutions can offer to their existing client base through correspondents, as well as the involvement the latter can have in the process of affiliating new clients. In general, regulators limit the role that correspondents can play in the provision of financial services, reflecting concerns over the reliability, security and competence of these third parties.

\section{Component A. Transactional services}

Description. This component measures the extent to which the regulation allows correspondents to offer transactional services, which are central to serving the most basic financial needs of the poor. These services include: (i) transfers, (ii) payments, (iii) deposits and withdrawals from bank accounts, (iv) disbursement and reimbursement of credit and (v) balance and movement enquiries. These all permit clients to conduct basic cash-in/cash-out operations in areas underserved by traditional branch or ATM channels.

Scoring. 
2: Regulation allows correspondents to offer at least four of the transactional services (i-v) listed above and these include transfers and payments.

1: Regulation allows correspondents to offer at least three of the transactional services (i-v) listed above and these include transfers and payments.

0: Regulation prohibits correspondents offering key transactional services (transfers and payments).

\section{Component B. Credit}

Description. Agents should not be permitted to play a decisive role in the process of granting credit on behalf of financial institutions, as this may raise concerns from a prudential perspective, as well as in terms of consumer protection, particularly if agent fees are linked to the volume of credit granted (CGAP, 2011a; CAF, 2013). However, agents could facilitate the provision of credit by collecting relevant information and documentation and sending it to bank employees, who will ultimately take the decision.

Scoring.

2: Correspondents can send and receive the information and documentation necessary for a loan to be granted.

1: Regulation does not specify the involvement of the agents in the process of granting credit.

0: Correspondents cannot send and receive the information and documentation necessary to grant a loan, OR are allowed to extend credit on behalf of financial institutions.

\section{Component C. Affiliation of new clients}

Description. Agents should be permitted to conduct customer due diligence, at least for financial products and with clients assessed as being of low risk for money laundering and terrorist financing. Therefore, agents should be allowed to complete the process of affiliation at least for simplified financial products (simplified bank accounts, electronic money) and expand access to standard accounts by collecting and sending relevant information and documentation (CGAP, 2011a; CAF, 2013). In any case, financial institutions must always be held liable for agent compliance with AML/CFT rules

Scoring.

2: Correspondents can complete the process of affiliation, at least for simplified financial products (simplified bank accounts, electronic money), even if they can only send and receive information and documentation for standard accounts, provided that financial institutions are held liable for agent compliance with AML/CFT rules.

1: Correspondents can only send and receive information and documentation, but not complete the process, even for simplified accounts.

0: Correspondents cannot intervene in the process of affiliation. 


\section{Transactional limits}

Description. This indicator assesses any limits to the volume or balance of operations, in general or by type of transaction (i.e. cash deposits and withdrawals) that the regulation establishes either by point of service or in aggregate.

Scoring.

2: Regulation requires the establishment to define limits to the volume or balance of operations performed by agents, but gives some room for each intermediary to set them.

1: Regulation does not deal with this issue.

0: Regulation specifies the limits to the volume or balance of operations performed by agents, and they are considered too restrictive.

\section{Operational requirements}

Description. The indicator values regulatory provisions that drive the cost of deployment and management of a network of correspondents. In particular, it assesses regulatory definitions related to the security of the information, training, in-line operation and records of transactions. This indicator is essential for the development of inclusive agents' networks given the economic implications of meeting operational requirements.

\section{Component A. Security of the information}

Description. Regulations on correspondents or agents should guarantee that these actors have the means and capacity to guarantee the security of the information handled, as well as ensuring the confidentiality of clients and operations. This requirement must always be fulfilled, irrespective of the cost implications (CAF, 2013a)

Scoring. 2: The security and confidentiality of client information is guaranteed through accessible means.

1: The security and confidentiality of client information is guaranteed through overly complex procedures and mechanisms.

0: Regulation does not deal with this issue.

\section{Component B. Training and capacity-building}

Description. Regulations on correspondents should guarantee that the accountable financial institution verifies that all employees of the correspondents have the necessary training and capacity to perform the activities they contract.

Scoring.

2: Correspondents are required to follow an accessible capacity-building process.

0: Regulation does not deal with this issue. 


\section{Component C. Records of transactions}

Description. Records of transactions need to be delivered to clients, although it might be more efficient from an economic perspective not to impose the delivery in hard copy as this might increase the cost of operations for agents (installing, supplying and maintaining printers)

Scoring.

2: Records of transactions can be delivered in hard copy or electronic format, as chosen by the client.

1: Records of transactions must be delivered in hard copy.

0 : Regulation does not deal with this issue.

\section{Component D. Online operations}

Description. The requirement to carry out transactions online implies that transactions must be carried out in real time and through electronic systems connected to the central systems of the bank. The requirement for online operations could be relaxed in certain specific instances, especially in the case of deposit or cash-in transactions, such as deposit in accounts, balance enquiries, payments of services and credits, among others in which there is no risk of fraud through multiple withdrawals. ${ }^{82}$ Even in these cases, however, it would be necessary to reconcile the offline transaction with the verification of applicable limits for simplified record accounts, if any. Flexibility of online operation can be important in contexts where it is not feasible, technically or economically, to implement continuous connectivity.

Scoring.

2: Online operation is required for every transaction that involves a withdrawal, although some degree of flexibility is allowed for payment or deposit transactions with no risk of fraud by multiple withdrawals.

1: All operations must be performed online, regardless of their nature.

0: Regulation does not require operations to be performed online, even in the case of transactions with risk of fraud through multiple withdrawals.

82: See CAF (2013a) 


\section{Supervision}

Description. The indicator relates to the initial (authorisation) and ongoing oversight requirements of the financial supervisor, as well as reporting requirements. In general, the supervisor should have clear and sufficient legal powers to issue regulations regarding agents and to monitor and enforce regulatory compliance. But at the same time, supervision should be risk-based, and based on an assessment of significance, to ensure supervisory resources are deployed effectively. ${ }^{83}$

\section{Component A. Authorisation}

Description. The authorisation process for using agents as a new channel should strike a balance between the need to review the proposed agent business and the need to optimise the use of supervisory resources. Thus, the authorisation should be for the financial institution to start using agents, and not for each new agency contract. As reported by CGAP (2015), the latter has been identified as a major obstacle by financial services providers in several countries.

Scoring.

2: Authorisation is for the financial institution to start using agents, and not for each new agency contract.

1: Authorisation is required for each new agency contract, but done in a bulk. Annual renewals are not necessary in order not to excessively burden providers.

0: Authorisation is required for each new agency contract and annual renewals are requested OR no authorisation is required.

\section{Component B. Ongoing supervision}

Description. Supervisors should be able to conduct offsite and onsite inspection of the agents' activities, by receiving relevant information and documentation and being enabled to visit the agents' premises if deemed necessary. However, reporting requirements should be consistent with the nature of the operations so as not to excessively burden financial providers. ${ }^{84}$

Scoring.

2: The supervisor can effectively supervise correspondents. This implies that the supervisor is enabled to conduct onsite inspections or visits to the correspondents, as well as request information and documentation that is reasonable and consistent with the correspondents' operations.

1: The supervisor has the capacity to supervise correspondents, but it is limited in some way. This implies that the supervisor is either not authorised to conduct onsite inspections or visits to the correspondents or that it cannot request information and documentation that is reasonable and consistent with the correspondents' operations.

83: See CGAP, 2015

84: CAF, 2013a 
0: The supervisor has no capacity to supervise correspondents, or the information requirements imposed are too restrictive given the nature and risks associated with the correspondents' operations.

\section{Interoperability and exclusivity}

Description. The indicator assesses the conditions on agents' interoperability as it relates to exclusivity (i.e. any given commercial establishment can only act as a correspondent for one institution). While interoperability increases the chances that multiple financial institutions will penetrate remote areas and locations, it is not advisable for regulators to mandate interoperability, especially at the early stage of development of the agents' networks since first movers might be reluctant to invest in the creation of these networks, as competitors might take advantage of the efforts to identify, train and oversee agents. The consensus, therefore, is to recommend that regulators allow agent exclusivity for financial institutions at least in the initial stages of development of the sector, as long as the platforms are interconnected to allow suppliers to compete effectively in the long term. ${ }^{85}$

\section{Scoring.}

2: Exclusivity is allowed but regulation requires that systems and necessary infrastructure should have the capacity to become interoperable.

1: Regulation does not deal with this issue.

0: Exclusivity is explicitly forbidden.

\section{Fees and commissions}

Description. The indicator assesses regulatory provisions related to fees charged to customers through correspondents and to the compensation paid by the financial institutions to the correspondents. Following best practices, financial services providers should be allowed to freely set the fees charged to consumers, unless entrenched monopoly powers are in place; financial institutions and correspondents should be allowed to freely negotiate the compensation and fees paid to correspondents; and correspondents should not be permitted to charge additional fees and commissions to customers.

\section{Component A. Compensation and fees paid to correspondents}

\section{Scoring}

2: There are no restrictions to the fees and/or remuneration set by the financial institution in contracting agents' services.

0 : There are significant restrictions to the fees or commissions set by the financial institution for the agents.

\footnotetext{
85: Although none of the countries in our sample explicitly mandates agent exclusivity, other countries have done so. For instance, regulation on branchless banking in Indonesia mandates that agents may only partner with one service provider (OJK Regulation No. 19/POJK.03/2014 dated 18 November 2014. See, KPMG Indonesia (2015)). However, Indonesia seems to be an exemption on this, and therefore this possibility has not been incorporated into the scoring.
} 


\section{Component B. Fees and commissions charged to clients}

Scoring.

2: There are no restrictions to the fees and commissions set by the financial institutions on clients, provided that correspondents cannot unilaterally charge additional fees to clients.

0: There are significant restrictions to the fees and commissions set by the financial institutions on clients OR the correspondents can unilaterally charge additional fees to clients.

- 9.B.a Adjusted fees and commissions charged to clients (for quality of competition policies)

Scoring

2: There are no restrictions to the fees and commissions set by the financial institutions on clients, correspondents cannot unilaterally charge additional fees to clients AND the sub-index on Competition Policies has a value greater than or equal to 1 ;

1: There are restrictions to the fees and commissions set by the financial institutions on clients, correspondents cannot by themselves charge additional fees to the client AND the sub-index on Competition Policies has a value lower than 1 ;

0 : There are no restrictions to the fees and commissions set by the financial institutions on clients AND the sub-index on Competition Policies has a value lower than 1;

0 : There are significant restrictions to the fees and commissions set by the financial institutions on clients AND the sub-index on Competition Policies takes a value greater than or equal to 1.

0: Correspondents can unilaterally charge additional fees to clients.

\section{I.F. Microcredit}

The Microcredit sub-index is made up of 4 indicators. The selection and subsequent definition of the indicators builds on the CGAP Consensus Guidelines on regulation and supervision of microfinance from 2012. Some of the indicators have several components. In that case, the score for the indicator is obtained as a simple average of the scores for the component. Each indicator and its components obtained a value in the 0-2 range, with higher values representing a more favourable framework. The indicators are then aggregated to obtain the final score, for which all indicators are weighted equally.

The definition of indicators and their components as well as the scoring criteria is given below.

\section{Regulatory framework}

Description. The regulatory framework for microcredit can be a promoter by permitting non-bank entities to engage in lending, by adjusting rules so that existing institutions can reach new customers or offer new services, by allowing the formation of new microfinance institutions (MFIs). When acting as a promoter, however, the regulation should aim at increasing competition and creating a level playing field. 


\section{Component A. Regulatory definition and dedicated framework ${ }^{86}$}

Description. The distinctive features of microcredit give rise to different risks, and this calls for a differentiated regulatory treatment from that applied to traditional lending activities (CGAP, 2012). The lack of a dedicated regulatory framework for microcredit might limit its outreach, since institutions engaged in this activity might be forced to comply with traditional financial regulations which are not suited to the particular features of the microlending activity. Furthermore, evidence from different studies at the MIT Poverty Action Lab ${ }^{87}$ point out that there is a clear differentiation in the impact on the borrowers of microcredit for productive activities and consumption lending. These studies point to a larger permanent effect on borrowers' income and welfare arising from microcredit to finance productive activities. Therefore, this differentiation should also be accounted for in the definition and regulation of microcredit.

Scoring.

2: There is an explicit definition and regulatory framework for the promotion of microcredit, and the regulation differentiates depending on the use of the funds.

1: Microcredit is defined but there is no dedicated regulatory framework or it does not differentiate depending on the use of the funds.

0: Microcredit is neither formally regulated nor defined.

\section{Component B. Functional approach}

Description: Regulation of financial services, and in this case, of microcredit, should always follow a functional approach that guarantees similar regulation for similar functions. A functional approach, therefore, is an approach to financial services regulation in which services of the same nature are regulated in the same way, rather than, for example, according to the type of provider (Claessens and Rojas-Suarez, 2016). This is essential in order to ensure a level playing field that fosters competition and reduces the risk of regulatory arbitrage.

Scoring.

2: Regulation on microcredit follows a functional approach.

0: Regulation on microcredit does not follow a functional approach, creating a non-level playing field or giving rise to regulatory arbitrage.

\section{Prudential regulation}

Description. Prudential regulation should apply to all deposit-taking microcredit institutions, but prudential requirements should be differentiated from those imposed on traditional credit portfolios, given the particular

\footnotetext{
86: We will not discuss whether rules on microcredit are incorporated by amending existing financial sector legislation or by creating a new specific framework, as this decision seems to be mostly influenced by country-specific factors (CGAP, 2012).

87: See for example Banerjee, A. V., Duflo, E., Glennerster, R., \& Kinnan, C. (2013)
} 
features of microcredit portfolios. The issues discussed below include the most common requirements under prudential regulatory frameworks, but others might need an adjustment as well. ${ }^{88}$

\section{Component A. Regulatory framework for risk management}

Scoring.

2: There is a differentiated and comprehensive risk regulatory framework for risk management for microcredit. A comprehensive risk management framework should cover rules on portfolio classification, provisions and collateral.

1: There is a differentiated regulatory framework for risk management, but it is not comprehensive.

0: There is no differentiated regulatory framework for risk management.

\section{Component B. Documentation requirements}

Description. The size of the loans and the nature and level of riskiness of the borrowers justify lighter documentation requirements for microcredit than for conventional retail portfolios (CGAP, 2012). For instance, in the granting of a traditional microloan there is no collateral appraisal and it also makes little sense to request formal financial statements of the borrower's business.

Scoring.

2: Loan documentation requirements are simplified for microcredit granting.

0: Loan documentation requirements are not simplified for microcredit granting.

\section{Microcredit supervision}

Description. Broader access to credit can compromise financial stability if not coupled with high-quality supervision standards (Sahay et al, 2015). In the context of microcredit, this requires an effective allocation of supervisory resources and a specialised understanding of the microcredit activity and the nature of the risks involved, which differ substantially from the ones that supervisors monitor for conventional retail bank portfolios. For instance, the quality of a typical microloan portfolio cannot be assessed in the same way as occurs with conventional commercial loans (BCBS, 2016). Therefore, this indicator aims to assess the capacity of the financial authorities to effectively oversee microcredit institutions, together with the necessary remedial and corrective powers. This depends on the knowledge, skills, resources and processes of the supervisory team to understand and oversee the risks involved in microcredit.

\footnotetext{
88: International institutions such as CGAP or the BCBS have engaged in a long debate on whether higher capital or liquidity requirements should be imposed on institutions that are deeply engaged in microcredit than those applied on traditional diversified financial institutions. For instance, BCBS (2010) states that in cases where deposit-taking institutions have fewer options to raise capital compared to banks or exhibit a more pronounced risk profile, a higher capital adequacy ratio might be justified. However, assessing national regulations in this regard would require a very deep, rigorous assessment of the nature, activities, funding structures and inherent risks of all the institutions that engage in microlending, which is beyond the scope of this work.
} 
Scoring. The scoring builds on the work by Trujillo-Tejeda et al. (2015), which summarises the guidelines and best practices outlined by three international institutions: the Association of Supervisors of Banks of the Americas (ASBA, 2010), the Basel Committee on Banking Supervision (BCBS, 2010) and the Consultative Group to Assist the Poor (CGAP, 2012).

The recommendations made by ASBA, BCBS and CGAP, summarised by Trujillo-Tejeda (2015) have then been combined to construct the following two components.

\section{Component A. Institutional framework for microcredit supervision}

Description. This component aims to assess the capacity of the financial authorities to effectively oversee microcredit institutions. It summarises the following recommendations from ASBA, CGAP and BCBS: (i) supervise deposit-taking depositions, (ii) regulate cooperatives above a specific size and serving nonmembers; (iii) create a specialised department for microfinance supervision and (iv) design specific tools regarding sanctions and corrective measures.

Scoring

2: At least all institutions engaged in microlending that take deposits from the public are subject to prudential supervision, as well as cooperatives above a specific size. There is a specialised department or agency for the supervision of microcredit and supervisors count with specific tools regarding sanctions and corrective measures for microcredit.

1.5: At least all institutions engaged in microlending that take deposits from the public are subject to prudential supervision, as well as cooperatives above a specific size. There is a specialised department or agency for the supervision of microcredit, but supervisors do not have specific tools regarding sanctions and corrective measures for microcredit.

1: At least all institutions engaged in microlending that take deposits from the public are subject to prudential supervision, as well as cooperatives above a specific size. There is not a specialised department or agency for the supervision of microcredit or specific tools regarding sanctions and corrective measures for microcredit.

0: Not all institutions engaged in microlending that take deposits from the public are subject to prudential supervision.

\section{Component B. Supervision procedures for microcredit}

Description. This component assesses the approach and procedures for the supervision of microcredit activity. It summarises the following recommendations from ASBA, CGAP and BCBS: (i) require simpler requirements to institutions that do not take deposits and (ii) apply the same disciplinary regime to all institutions and (iii) allow in situ and remote supervision procedures.

Scoring.

2: Regulation contemplates in situ and remote supervision procedures AND the latter is conducted through reporting requirements that are tailored to the size and complexity of the institutions. 
1: Regulation does not contemplate in situ supervision procedures OR remote supervision is conducted through reporting requirements not tailored to the size and complexity of the institutions.

0: Regulation does not contemplate in situ supervision procedures AND remote supervision is conducted through reporting requirements not tailored to the size and complexity of the institutions.

\section{Non-prudential regulation}

Description. Non-prudential regulation governs the business conduct of financial institutions. There is a general consensus that all providers should be subject to non-prudential regulatory requirements to protect consumers and avoid other types of fraud, and these requirements should be based on the type of activity or transaction, and not on the nature of the institution and whether it is prudentially regulated or not. Therefore, non-prudential regulation generally applies to both depositary and non-depositary institutions and generally focuses on the following issues: adequacy and transparency of the information and ensuring effective protection of microcredit clients.

Two topics that are commonly cited when analysing the non-prudential requirements for microcredit are the existence of interest rate caps on microloans and the quality and accessibility of credit reporting systems. However, both issues have been dealt with in detail in other sub-indices and are not touched upon here.

\section{Component A. Consumer protection}

Description. Financial consumer protection is of particular relevance when applied to the low-income population, as in general they show lower levels of financial education and have little experience with formal financial services. In broad terms, a comprehensive consumer protection framework focuses on ensuring fair treatment of clients—avoiding discrimination against clients or abusive lending and collection practices—and giving clients the opportunity of addressing complaints and handling disputes through an affordable mechanism (CGAP, 2012). As far as possible, all providers of a given financial service should be subject to the same consumer protection standards (Claessens and Rojas-Suarez, 2016; CGAP, 2012). All microcredit clients should be entitled to the same level of protection, and therefore should be protected to the same extent from abusive practices regardless which type of financial provider offers the service.

Scoring.

2: A comprehensive consumer protection framework exists and similar rules apply to every microcredit provider.

1: A consumer protection framework exists and similar rules apply to every microcredit provider, but they are not comprehensive, at least for some provider.

0: Consumer protection rules are significantly different among the different microcredit providers or some type of microcredit provider is not subject to any consumer protection requirements.

\section{Component B. Disclosure and Transparency}

Description. Microcredit providers should be required to give clients comprehensive information about the services offered, including their terms and costs. However, there are diminishing returns to the volume of information disclosed. Therefore, regulation should focus on simplicity, accuracy and clarity, rather than on 
the quantity of data made available to consumers (CGAP, 2012). Furthermore, transparency rules often represent an additional effort by the regulator to facilitate comparability of products and providers. Such efforts can facilitate informed decision-making for microcredit clients and promote competition in the market.

Scoring.

2: All microcredit providers are required to give clients clear and complete information about services offered, including their terms and costs AND the regulator publishes information in an accessible, complete and comparable way.

1.5: All microcredit providers are required to give clients clear and complete information about services offered, including their terms and costs BUT the regulator does not publish information in an accessible, complete and comparable way.

0.5: Not all microcredit providers are required to give clients clear and complete information about services offered, including their terms and costs, BUT the regulator publishes information on regulated institutions in an accessible, complete and comparable way.

0: Not all microcredit providers are required to give clients clear and complete information about services offered, including their terms and costs AND the regulator does not publish information in an accessible, complete and comparable way.

\section{I.G. Credit Reporting Systems}

The Credit Reporting Systems sub-index is made up of 2 indicators: The comprehensiveness of information indicator and the accessibility and safety indicator. The indicators have several components and the score for each indicator is obtained as the average of the scores for its components. Each indicator and its components obtain a value in the $0-2$ range, with higher values representing a more favourable framework. The indicators are then aggregated to obtain the final score, for which the two indicators are equally weighted.

The definition of indicators and their components and the scoring criteria are shown below.

\section{Comprehensiveness of information}

Description. The indicator captures the scope and coverage of the information that can or must be stored in credit information systems, building on the belief that credit history data from alternative sources, in addition to banks and other financial institutions, is critical to the establishment of a well-developed and inclusive financial infrastructure. Also, it attempts to capture the nature of the information and the types of borrowers covered. In defining the scoring method used, it is important to note that regulations applicable to public credit registries are on a "requirement basis" (that is, in general, rules on public credit registries require financial institutions to disclose a set of information defined by law). By contrast, rules regarding private bureaus are usually on a "permission basis" (that is, rules define which information can and cannot be gathered in a private credit bureau, but there are no explicit requirements or mandates)

\section{Component A. Sources of information}


Description. This component assesses whether credit reporting systems are required (in the case of public registries) or permitted (in the case of private bureaus) to report repayment data from institutions other than banks. The rationale behind this requirement/permission arises from the fact that smaller firms and individuals usually rely heavily on informal sources such as borrowing from family and friends or from unregulated lenders. If the credit reporting system only covers credit information from banks, an individual without an established credit history would face significant obstacles to securing a loan from a formal financial institution. This situation can be mitigated if information covered in the credit reporting system includes up-to-date data from other sources, such as payment and credit records from utility companies, trade creditors, retailers and microfinance institutions. Countries in the sample show different levels of credit bureau/registry coverage. In general, coverage is higher in countries when regulation allows a broader set of information to be contained in the credit information system. ${ }^{89}$

Scoring.

2: If existing, public credit registries are required to contain information from all regulated financial intermediaries, AND

There are no legal impediments to private credit bureaus gathering information from banks and other financial institutions, retailers and utilities companies

1: If existing, public credit registries are required to contain information from all regulated financial intermediaries, AND

There are no legal impediments to private credit bureaus gathering information from banks, other financial institutions, and some but not all of the additional sources available

0.5: 1: If existing, public credit registries are required to contain information from all regulated financial intermediaries, BUT

89: Credit bureau/registry coverage reports the number of individuals and firms listed in a credit bureau/registry's database as of January 1, 2016. The number is expressed as a percentage of the adult population (the population age 15 and above in 2015, according to the World Bank's World Development Indicators). The definition and data were obtained from the World Bank's 2017 Doing Business Report.

$\begin{array}{lcc} & \text { Credit registry coverage (\% adults) } & \text { Credit bureau coverage }(\% \text { adults) } \\ \text { Argentina } & 41.6 & 100 \\ \text { Brazil } & 53.4 & 78.9 \\ \text { Chile } & 48.4 & 12.4 \\ \text { Colombia } & \text { n.a. } & 92.1 \\ \text { Mexico } & \text { n.a. } & 100 \\ \text { Paraguay } & 24.4 & 45.3 \\ \text { Peru } & 37.4 & 100 \\ \text { Uruguay } & 100 & 100 \\ & \end{array}$


Private credit bureaus are allowed to gather information from banks and other financial but not from any additional sources (such as retailers or utilities companies)

0: Credit reporting systems are not operational or not required to be regularly updated

\section{Component B. Nature of the information}

Description. The component assesses whether credit information systems need to include comprehensive negative and positive information on each data subject. Positive information covers facts of contractually compliant behaviour. It includes detailed statements about outstanding credit, amount of loans, repayment patterns, assets and liabilities, as well as guarantees and/or collateral. By contrast, negative credit reporting, or negative information normally refers to unfulfilled financial obligations, such as late payments, defaults or arrears and bankruptcies. It may also include statements about lawsuits, liens and judgments that are obtained from courts or other official sources. ${ }^{91}$ For low-income population, positive information constitutes a sort of "reputation collateral" that can be a highly valuable asset in replacement of the tangible collateral they often lack. ${ }^{92}$

Scoring.

2: Private credit bureaus are allowed to gather comprehensive negative and positive information, AND, when existing, public credit registries are required to do so.

1: Private credit bureaus are allowed to gather comprehensive negative and positive information, BUT existing public credit registries are only required to gather negative information.

0.5: Existing public credit registries are required to gather negative and positive information, BUT private credit bureaus are only allowed to gather negative information.

0: Private credit bureaus are only allowed to gather negative information AND public credit registries, when existing, are only required to gather negative information.

\section{Component C. Borrowers covered}

Description. Credit markets for small companies or microentrepreneurs is the segment of the credit market most likely to be affected by the problem of asymmetry of information, as there is generally no independent analysis of these companies. Thus, for improving financial inclusion, credit information systems should include data covering these firms.

\footnotetext{
90: Public credit registries gather information from regulated financial intermediaries and, therefore, do not include information from other sources, such as retailers or utilities companies. Hence, public registries only cover the population that has been previously engaged within the formal financial system; unlike the private bureaus which can reach individuals that have never been engaged with the formal financial system. Consequently, the inclusion of positive information in the private bureau takes on greater importance from the point of view of promoting financial inclusion.

91: See World Bank (2011a)

92: Moreover, financial institutions in Latin American countries have claimed to place greater importance on this information than on the tangible collateral backing the loan (IADB, 2005).
} 
Scoring.

2: Public credit registries are required to and cover data on both firms and individuals, including on SMEs, microentrepreneurs and other microcredit clients AND private credit bureaus are allowed to do so.

0: Public credit registries are not required to cover data either on both firms and individuals, or on microcredit clients, OR private credit bureaus are not allowed to cover data on firms, individuals or microcredit clients.

\section{Accessibility and safety}

Description. The indicator assesses the feasibility and ease of borrowers to access their data in the credit bureau/credit register and of lenders to access borrowers' credit information and use it to assess their creditworthiness, as well as the level of security offered to participants in the credit reporting system.

\section{Component A. Borrowers' access}

Description. Effective protection of borrowers in a credit reporting system requires also effectively safeguarding them from the negative consequences of inaccurate data collection. Thus, customers should be given the right to access the information held on them, and be able to challenge and correct it if necessary. Ideally, this procedure should be straightforward and inexpensive for borrowers.

Scoring.

2: The law requires that borrowers can access their credit information and are able to amend existing mistakes in public credit registries and private credit bureaus.

1: The law requires that borrowers can access their credit information but the process to amend existing mistakes is difficult or unaffordable.

0: The law is silent regarding borrowers' access to their credit information or does not enable them to amend existing mistakes

\section{Component B. Lenders' access}

Description. The information contained in the credit reporting system should be available for users of the system in a prompt and convenient manner to enable them to carry out their functions appropriately. Thus, lenders should be able to access standardised information on borrowers through an online platform. ${ }^{93}$

Scoring.

\footnotetext{
93: In some cases, credit reporting service providers add value to the data they gather by consolidating various information pieces and introducing additional tools to help users assess the risk profile of each borrower. These value-added services might include, for instance, credit scoring, which is defined as a statistical method of evaluating the probability of a prospective borrower to fulfil their financial obligations associated with a loan. However, provision of these services tend not to be regulated. In the countries in our sample, only Mexico explicitly allows for the provision of these value-added services. In practice, however, credit bureaus in many other countries provide them.
} 
2: 'Banks and financial institutions are allowed to access borrowers' credit information online (for example, through an online platform, a system-to-system connection)

0: The law is silent regarding the ability of banks and financial institutions to access borrowers' credit information online (for example, through an online platform, a system-to-system connection).

\section{Component C. Data protection}

Description. The Data protection component assesses the extent to which privacy rights exist and are observed. This refers to the level of security offered to borrowers regarding the uses and protection of their information and legal protection for lenders regarding confidentiality issues.

Scoring.

2: There are rules in place to protect privacy rights for borrowers and lenders, and these rules are effectively enforced.

1: Rules in place to protect privacy rights do not cover either borrowers or lenders, or they are not effectively enforced.

0 : There are no rules in place to protect privacy rights for borrowers and lenders.

\section{I.H. Simplified KYC Requirements}

The Simplified KYC sub-index is made up of 4 indicators. Each indicator obtains a value in the 0-2 range, with higher values representing a more favourable framework. The indicators are then aggregated to obtain the final score, for which all indicators are equally weighted.

The definition of the indicators and the scoring criteria are shown below.

\section{Level playing field}

Description. Recommendations on KYC need to be consistent with the general principle of a level playing field. Therefore, they should be similar for all the providers of the same service and not favour banks, electronic money providers or any other institution.

Scoring.

2: $\mathrm{KYC}$ rules are equivalent for all providers of the same financial service, thus supporting a level playing field.

0: KYC rules are not equivalent for all providers of the same financial service, thus hindering a level playing field.

\section{Identification requirements}


Description. The FATF recommendations do not specify the exact customer information that financial services providers must collect. Under a risk-based, tiered KYC requirement, customer identification for low-risk scenarios would typically consist of name, date of birth and identification number. However, national legislation varies considerably, with some countries requiring other types of information such as customer's occupation, income, proof of address, or payslip receipt, which could be unavailable or unaffordable for the low-income population to obtain. In fact, according to the 2014 World Bank's Global Findex Survey, documentation requirements are among the most important barriers to account ownership, cited by 18 percent of adults without an account globally. Still, the FATF Guidance rightly notes that tiered KYC requirements never mean an exemption of CDD, but rather a simplification.

Scoring.

2: KYC requirements are scaled to the size, nature and risks of clients and transactions. Simplified identification requirements are minimal, trying to identify the individual only, and are accessible for every individual (they do not involve proof of address, payment of utility bills or sources of income).

1: KYC requirements are partly scaled to the size, nature and risks of clients and transactions. However, simplified identification requirements are not truly minimal and could limit financial inclusion (information requirements are too restrictive or a significant percentage of the target population does not have access to the required documents).

0: KYC requirements are not scaled to the size, nature and risks of clients and transactions.

\section{Verification requirements}

Description. According to the financial industry, the verification stage is usually the most difficult, burdensome and costly part of the CDD procedure (FATF, 2013). Usually, countries rely on government-issued ID systems to ensure reliable verification of customers' identity. However, a prerequisite for this to be effective is that these systems are robust enough to avoid the risk of individuals opening several accounts under different identities. Furthermore, sometimes the national legal system is non-existent, not widespread or not affordable for low-income population. In such cases, countries need to introduce some flexibility by relying on a broader range of identification measures that can be reliably checked by financial service providers. In some cases, regulators could allow alternative accredited forms of identification, such as a voting card, a student card, a letter form a village chief or other community leader, a tax certificate, healthcare document or a birth certificate. The FATF Guidance cites these and other examples of acceptable IDs, while cautioning countries to be mindful of the higher risk of fraud or abuse of these alternative forms of identification. ${ }^{94}$ In any case, when necessary, national identification systems should be strengthened to facilitate compliance with KYC while not hindering financial inclusion efforts.

Scoring.

2: National legislation clearly identifies the documents that can be used to reliably verify customer's identity AND the national ID system is strong, accessible, affordable for low income population and its veracity can be reliably checked by financial services providers.

\footnotetext{
94: This approach has been followed for instance in Fiji. Other countries, such as the Democratic Republic of Congo, have opted to align SIM card registration with KYC requirements for mobile money (Di Castri et al, 2015).
} 
1.5 National legislation clearly defines the documents that can be used to reliable verify customers' identity, BUT the national ID system is weak, not accessible or not affordable for low-income population. However, in those cases a broader range of identifications means are accepted.

0.5: National legislation clearly defines the documents that can be used to reliably verify customers' identity, BUT the national ID system is weak, not accessible or affordable for low income population AND no other forms of identification means are accepted.

0.5: National legislation clearly defines the documents that can be used to reliably verify customers' identity. The national ID or alternative means is accessible for low income population BUT its veracity cannot be reliably checked by financial services providers.

0: National legislation does not clearly define the documents that can be used to reliably verify the identity of customers.

\section{Record-keeping requirements}

Description. The FATF Recommendations state that providers of financial services should keep records of the identification data obtained through the customer due diligence process for at least five years. This includes keeping record of official identification documents, such as passports, driver's licences, identity cards or any other relevant document or analysis. The record-keeping requirement is fully applicable to the CDD procedures and information, regardless of the risks associated with the transaction. However, the FATF Guidance does not impose the retention of physical copy of the documentation provided, and instead allows different forms of record-keeping, such as electronic storage or even a handwritten recording of the reference details of the identity documents (reference number, relevant dates and identity details). This is particularly important in the context of financial inclusion where the ability to operate through agents is of the utmost importance. ${ }^{95}$

Scoring.

2: Record-keeping requirements are streamlined, for instance, by permitting records to be kept electronically or through a handwritten recording of the reference details of the identity documents.

1: Record-keeping requirements impose the retention of physical copy of the documentation provided

0: The regulation does not define record-keeping requirements.

\section{I.I. Financial Literacy}

The Financial Literacy sub-index is made up of 2 indicators, which have several components. The score for each indicator is obtained as a simple average of the scores of the components. Each indicator and its components obtained a value in the 0-2 range, with higher values representing a more favourable framework. The indicators are then aggregated with equal weighting to obtain the final score.

95 In fact, as reported by FATF (2013) developed countries such as Australia, Canada or the United States do not impose photocopying requirements due to the risk of identity fraud and breach of privacy laws. 
The definition of the indicators and the scoring criteria are shown below.

\section{Financial education capacity}

\section{Component A. Institutional framework}

Description. Following the OECD/INFE 2012 High Level Principles, financial education policies are better framed within a nationally coordinated approach that recognises the importance of financial education. Furthermore, the Principles also suggest that there should be one or more public institutions with a clear and formal responsibility for financial education, and resources specifically earmarked for achieving this goal. This institution might be a finance or education ministry, the central bank, the financial supervisor or even a specifically created body made up of multiple stakeholders. This have been found to improve accountability and visibility to the public and facilitate coordination in the implementation phase (OECD/INFE, 2015).

Scoring.

2: There is a coordinated policy response in place in the country for promoting financial education. There are also one or more public institutions with an explicit mandate for financial education.

1.5: There is no coordinated policy response for promoting financial education in the country but there are one or more public institutions with an explicit mandate for financial education.

1: There is not a coordinated policy response for promoting financial education in the country, but some policies have been put in place by public institutions, even if they do not have an explicit mandate for financial education.

0: No policy has been put in place for promoting financial education in the country or there is no institution aiming at promoting financial education.

\section{Component B. Coordination}

Description. The framework for promoting financial education should involve cross-sectoral coordination at national level of all interest stakeholders (public and private). These should encompass all relevant public authorities (including ministries, the central bank and financial authorities), but their actions should be mindful not to substitute or duplicate existing efficient initiatives by private parties. Furthermore, the OECD/INFE High Level Principles suggest that the role of the private sector and financial services providers should be promoted, although this participation should be monitored to avoid the emergence of conflicts of interest

Scoring.

2: The framework for promoting financial education involves cross-sectoral coordination at national level of relevant public authorities as well as the private sector, AND the latter is subject to monitoring to avoid potential conflicts of interest. 
1: The framework for promoting financial education involves cross-sectoral coordination at national level of relevant public authorities, BUT the participation by the private sector is either not considered or not monitored.

0: The framework for promoting financial education does not involve cross-sectoral coordination at national level of relevant public authorities and the private sector.

\section{Policy efforts}

\section{Component A. Target}

Description. Financial education policies should be provided to individuals who are in an environment that is conducive to learning, such as adolescents or young adults at school, college or the workplace. The timing of financial education policies is also crucial, and evidence suggests that timing financial education efforts to coincide with important financial decisions increases the likelihood of lasting improved financial knowledge or an influence on financial behaviour (OECD/INFE, 2012; IPA; 2017).

Scoring.

2: Financial education policies identify target groups, including individuals who are in an environment that is conducive to learning or coinciding with important financial decisions. Financial education has been incorporated into the education programme.

1: Financial education policies do not identify target groups but are targeted at the general public. Financial education has been incorporated into the education programme.

0: Financial education policies do not identify target groups but are targeted to the general public. Financial education has not been incorporated into the education programme.

\section{Component B. Direct access to products}

Description. Providing financial education alongside to access to appropriate financial products can have important benefits (OECD, 2015). On the one hand, the potential for accessing a financial product can be a powerful incentive for people signing up for financial education. On the other hand, it can help increase understanding of the financial product or service, thus boosting the potential impact on access and use of financial products of other policies. One way to achieve this objective is to incorporate financial education considerations in the design of welfare programmes, such as the distribution of conditional cash transfers through simplified accounts. In fact, there is evidence that the low level of usage of these accounts in several countries is largely explained by the low levels of financial literacy of the transfer recipients (CGAP, 2011)

2: Financial education is included in the design of welfare programmes such as the distribution of conditional cash transfers through simplified accounts.

0: Financial education is not included in the design of welfare programmes such as the distribution of conditional cash transfers through simplified accounts.

\section{Component C. Convenience}


Description. One of the main challenges faced by public authorities implementing financial education policies is how to ensure that these policies reach and change the financial behaviour of the target population. To this end, these policies should employ a wide range of appropriate delivery and communication channels, such as websites, the media and seminars (OECD, 2012, 2015; IPA; 2017)

Scoring.

2: Access to information and advice is facilitated through multi-channel delivery, including through alternative and innovative channels such as media or social networks.

1: Access to information and advice is facilitated through multi-channel delivery, but not through alternative and innovative channels such as media or social networks.

0: Access to information and advice is not facilitated through multi-channel delivery.

\section{I.J. Financial Transaction Taxes}

Description. This sub-index is made up of one indicator that measures the usage of financial transaction taxes adjusted to consider mitigating factors that constrain the adverse impact of the taxes on financial inclusion. In a first step, the unadjusted indicator is constructed using the following scoring system:

\section{Scoring}

2: There is no tax on financial transactions in force in the country.

0 : There is a tax on financial transactions in force in the country (whether debit or credit transactions)

In a second step the indicator is adjusted by increasing its value if there are any mitigating factors. The adjustment takes place in the following way:

\section{A Adjustment for fiscal deductions}

+0.5: The financial transaction tax can be fully deducted or credited against the payment of other taxes (for instance, personal income tax or the value-added tax)

\section{B Adjustment for exceptions in payment of tax}

+0.5 : The design of the tax base or exemptions helps reduce the adverse effect of the tax on access to financial services by the low-income population

\section{Adjustment for close to zero tax rate}

+0.5 : The tax rate is very close to zero to allow the gathering of information by the fiscal authority, thus helping increase the collection of other taxes.

The resulting adjusted score equals the overall score for the sub-index. 


\section{I.K. Interest Rates Ceilings}

Description: This sub-index is made up of one indicator that assesses whether interest rate ceilings distort the provision of credit. The larger the constraints created by the regulation on the provision of credit to small enterprises or low income customers, the lower the score.

Scoring.

2: There are no interest rate ceilings

1.5: There are interest rate ceilings but they are not restrictive for the provision of any type of credit.

1: There are interest rate ceilings, and even though they are restrictive for the provision of some types of credit, they do not distort the provision of microcredit or low value credit.

0: There are interest rate ceilings, and they are restrictive for the provision of microcredit or low value credit.

The score attached to each country equals that country's overall score for the sub-index on Interest Rates Ceilings

\section{I.L. Directed Lending}

Description: This sub-index is made up of one indicator that assesses whether government interventions distort credit markets and hamper financial inclusion. The larger the distortions created, either through government mandates to private banks to allocate credit to specific sectors or by direct lending provided by first-tier public banks under non-competitive conditions, the lower the scores.

Scoring

2: The Government does not interfere in the allocation of credit OR it does so in a way that ensures that public sectors efforts complement rather than substitute (crowd in rather than crowd out) private sector efforts to allocate credit. The latter refers to a second-tier bank lending model that addresses existing market failures without creating additional distortions.

1: Credit allocation is influenced by the Government through a second-tier bank lending model or through direct lending by a state-owned bank, and the scheme introduces partial distortions in localised credit markets.

0: Credit allocation is influenced by the Government either in the form of directed lending or through direct lending by (first tier) state-owned banks. This creates a general distortion in credit markets.

The score attached to each country equals that country's overall score for the sub-index on Directed Lending. 


\section{Annex II: Competition Policies: Summary of Regulatory Findings}

\begin{tabular}{|c|c|c|c|c|c|c|c|c|}
\hline Criteria/ Country & Argentina & Brazil & Chile & Colombia & Mexico & Paraguay & Peru & Uruguay \\
\hline 1. Market entry & 1.3 & 1.3 & 2 & 2 & 1.3 & 1.7 & 1.7 & 1.3 \\
\hline $\begin{array}{l}\text { 1A. Foreign bank } \\
\text { restriction }\end{array}$ & $\begin{array}{l}2 \text { There are no legal } \\
\text { impediments to foreign } \\
\text { financial institutions } \\
\text { entering, operating or } \\
\text { exiting Argentina. The } \\
\text { legal regime provides } \\
\text { for equal treatment of } \\
\text { foreign and domestic } \\
\text { entities. }\end{array}$ & $\begin{array}{l}1 \text { The Constitution } \\
\text { prohibits branches and } \\
\text { subsidiaries of foreign } \\
\text { banks, but provides } \\
\text { waivers through a } \\
\text { complex legal } \\
\text { framework that } \\
\text { ultimately requires } \\
\text { approval by the } \\
\text { President. }\end{array}$ & $\begin{array}{l}2 \text { Financial legislation } \\
\text { allows explicitly for the } \\
\text { opening of both } \\
\text { subsidiaries and branches. }\end{array}$ & $\begin{array}{l}2 \text { Financial legislation } \\
\text { allows explicitly for } \\
\text { the opening of both } \\
\text { subsidiaries and } \\
\text { branches. }\end{array}$ & $\begin{array}{l}2 \text { Legislation does not } \\
\text { contemplate the } \\
\text { establishment of } \\
\text { branches of foreign } \\
\text { banks. The only way } \\
\text { to operate as a bank is } \\
\text { by establishing a } \\
\text { Mexican corporation }\end{array}$ & $\begin{array}{l}2 \text { Financial legislation } \\
\text { allows explicitly for the } \\
\text { opening of both } \\
\text { subsidiaries and } \\
\text { branches. }\end{array}$ & $\begin{array}{l}2 \text { There are no legal } \\
\text { impediments to foreign } \\
\text { financial institutions } \\
\text { entering, operating or } \\
\text { exiting Peru. The legal } \\
\text { regime provides for } \\
\text { equal treatment of } \\
\text { foreign and domestic } \\
\text { entities. }\end{array}$ & $\begin{array}{l}2 \text { Foreign banks are } \\
\text { allowed to set up } \\
\text { subsidiaries and } \\
\text { branches in Uruguay }\end{array}$ \\
\hline 1B. State-bank ownership & $\begin{array}{l}2 \text { The } 12 \text { state-owned } \\
\text { banks account for about } \\
45 \% \text { banking sector } \\
\text { assets. Some of these } \\
\text { institutions compete } \\
\text { with commercial banks } \\
\text { as first-tier banks, but } \\
\text { they are subject to the } \\
\text { same regulation and } \\
\text { supervision }\end{array}$ & $\begin{array}{l}1 \text { Public banks have } \\
\text { access to less } \\
\text { expensive funding } \\
\text { than commercial } \\
\text { banks. However, they } \\
\text { are subject to the same } \\
\text { regulation and } \\
\text { supervision. }\end{array}$ & $\begin{array}{l}2 \text { Public banks compete } \\
\text { with private banks under } \\
\text { the same conditions, and } \\
\text { are subject to the same } \\
\text { regulation and } \\
\text { supervision. }\end{array}$ & $\begin{array}{l}2 \text { Public banks } \\
\text { compete with private } \\
\text { banks under the same } \\
\text { conditions, and are } \\
\text { subject to the same } \\
\text { regulation and } \\
\text { supervision. }\end{array}$ & $\begin{array}{l}2 \text { Public banks compete } \\
\text { with private banks } \\
\text { under the same } \\
\text { conditions, and are } \\
\text { subject to the same } \\
\text { regulation and } \\
\text { supervision. }\end{array}$ & $\begin{array}{l}1 \text { Public banks compete on } \\
\text { unequal terms with } \\
\text { private banks, as they } \\
\text { have exclusivity over } \\
\text { some activities which } \\
\text { allow them to get funded } \\
\text { at lower costs. The } \\
\text { organic Law of each } \\
\text { public institution prevails } \\
\text { over the Financial Sector } \\
\text { Law }\end{array}$ & $\begin{array}{l}1 \text { Public banks compete } \\
\text { on unequal terms with } \\
\text { private banks. They } \\
\text { have the exclusivity } \\
\text { over some activities } \\
\text { which allow them to } \\
\text { get funded at lower } \\
\text { costs. }\end{array}$ & $\begin{array}{l}0 \text { The sector is marked by } \\
\text { a high degree of } \\
\text { segmentation between } \\
\text { public and private } \\
\text { banks. Until recently, } \\
\text { BROU enjoyed a } \\
\text { monopoly on public } \\
\text { employee accounts by } \\
\text { law. }\end{array}$ \\
\hline $\begin{array}{l}\text { 1C. Entry of Digital } \\
\text { Service Providers (DSPs) }\end{array}$ & $\begin{array}{l}0 \text { DSPs are not allowed to } \\
\text { enter the market for the } \\
\text { provision of digital } \\
\text { financial services }\end{array}$ & $\begin{array}{l}2 \text { For DSPs that restrict } \\
\text { activities to } \\
\text { transactional services } \\
\text { or that offer stores of } \\
\text { value fully backed by } \\
\text { safe assets, entry } \\
\text { requirements are } \\
\text { minimal. }\end{array}$ & $\begin{array}{l}2 \text { For DSPs that restrict } \\
\text { their activities to } \\
\text { transactional services or } \\
\text { that offer stores of value } \\
\text { fully backed by safe } \\
\text { assets, the requirements } \\
\text { for entry are minimal. }\end{array}$ & $\begin{array}{l}2 \text { For DSPs that restrict } \\
\text { activities to } \\
\text { transactional services } \\
\text { or that offer stores of } \\
\text { value fully backed by } \\
\text { safe assets, entry } \\
\text { requirements are } \\
\text { minimal. }\end{array}$ & $\begin{array}{l}0 \text { DSPs are not allowed } \\
\text { to enter the market for } \\
\text { the provision of digital } \\
\text { financial services }\end{array}$ & $\begin{array}{l}2 \text { For DSPs that restrict } \\
\text { their activities to } \\
\text { transactional services or } \\
\text { that offer stores of value } \\
\text { fully backed by safe } \\
\text { assets, the requirements } \\
\text { for entry are minimal. }\end{array}$ & $\begin{array}{l}2 \text { For DSPs that restrict } \\
\text { activities to } \\
\text { transactional services } \\
\text { or that offer stores of } \\
\text { value fully backed by } \\
\text { safe assets, entry } \\
\text { requirements are } \\
\text { minimal. }\end{array}$ & $\begin{array}{l}2 \text { For DSPs that restrict } \\
\text { activities to } \\
\text { transactional services or } \\
\text { that offer stores of } \\
\text { value fully backed by } \\
\text { safe assets, entry } \\
\text { requirements are } \\
\text { minimal. }\end{array}$ \\
\hline 2. Market exit & 1.5 & 2 & 1.8 & 0.8 & 2 & 1.8 & 0.8 & 1.8 \\
\hline 2A. Exist rules for banks & 2 & 2 & 2 & 2 & 2 & 2 & 2 & 2 \\
\hline $\begin{array}{l}\text { Adjustment for alignment } \\
\text { with international } \\
\text { standards }\end{array}$ & $\begin{array}{l}\text { 1.5 Tools available include } \\
\text { transfers of assets and } \\
\text { liabilities and } \\
\text { liquidation. The country } \\
\text { does not require the } \\
\text { elaboration of neither } \\
\text { resolution nor recovery } \\
\text { plans }\end{array}$ & $\begin{array}{l}2 \text { Tools available include } \\
\text { transfers of assets and } \\
\text { liabilities and } \\
\text { liquidation. } \\
\text { Brazil has adopted } \\
\text { FSB standards on } \\
\text { recovery and } \\
\text { resolution plans. }\end{array}$ & $\begin{array}{l}\text { 1.5 Tools available include } \\
\text { transfers of assets and } \\
\text { liabilities and liquidation. } \\
\text { The country does not } \\
\text { require the elaboration of } \\
\text { neither resolution nor } \\
\text { recovery plans }\end{array}$ & $\begin{array}{l}\text { 1.5 Tools available } \\
\text { include transfers of } \\
\text { assets and liabilities } \\
\text { and liquidation. The } \\
\text { country does not } \\
\text { require resolution nor } \\
\text { recovery plans }\end{array}$ & $\begin{array}{l}2 \text { Tools available include } \\
\text { transfers of assets and } \\
\text { liabilities and } \\
\text { liquidation. The } \\
\text { country requires the } \\
\text { elaboration of } \\
\text { resolution and } \\
\text { recovery plans }\end{array}$ & $\begin{array}{l}\text { 1.5 Tools available include } \\
\text { transfers of assets and } \\
\text { liabilities and liquidation. } \\
\text { The country does not } \\
\text { require the elaboration } \\
\text { of neither resolution nor } \\
\text { recovery plans }\end{array}$ & $\begin{array}{l}\text { 1.5 Tools available include } \\
\text { transfers of assets and } \\
\text { liabilities and } \\
\text { liquidation. The } \\
\text { country does not } \\
\text { require the elaboration } \\
\text { of neither resolution } \\
\text { nor recovery plans }\end{array}$ & $\begin{array}{l}\text { 1.5 Tools available include } \\
\text { transfers of assets and } \\
\text { liabilities and } \\
\text { liquidation. The } \\
\text { country does not } \\
\text { require the elaboration } \\
\text { of neither resolution } \\
\text { nor recovery plans }\end{array}$ \\
\hline $\begin{array}{l}\text { 2B. Exit of Digital } \\
\text { Service Providers }\end{array}$ & $\begin{array}{l}\text { n.a. Digital services } \\
\text { providers are not } \\
\text { allowed to enter the } \\
\text { market for the } \\
\text { provision of digital } \\
\text { financial services }\end{array}$ & $\begin{array}{l}2 \text { Market exit rules for } \\
\text { payment institutions } \\
\text { follow commercial } \\
\text { bankruptcy laws, while } \\
\text { providing safeguards } \\
\text { for customers' funds. }\end{array}$ & $\begin{array}{l}2 \text { Market exit rules for non- } \\
\text { bank e-money issuers } \\
\text { follow commercial } \\
\text { bankruptcy laws, while } \\
\text { providing safeguards for } \\
\text { customers' funds. }\end{array}$ & $\begin{array}{l}0 \text { In case of insolvency } \\
\text { DSPs are governed } \\
\text { by the same rules that } \\
\text { apply for other } \\
\text { financial institutions } \\
\text { like banks. }\end{array}$ & $\begin{array}{l}\text { n.a. Digital services } \\
\text { providers are not } \\
\text { allowed to enter the } \\
\text { market for the } \\
\text { provision of digital } \\
\text { financial services }\end{array}$ & $\begin{array}{l}2 \text { Market exit rules for } \\
\text { non-bank e-money } \\
\text { issuers follow } \\
\text { commercial bankruptcy } \\
\text { laws, while providing } \\
\text { safeguards for } \\
\text { customers' funds. }\end{array}$ & $\begin{array}{l}0 \text { In case of insolvency } \\
\text { DSPs are governed by } \\
\text { the same rules that } \\
\text { apply for other } \\
\text { financial institutions } \\
\text { like banks. }\end{array}$ & $\begin{array}{l}2 \text { Market exit rules for } \\
\text { non-bank e-money } \\
\text { issuers follow } \\
\text { commercial bankruptcy } \\
\text { laws, while providing } \\
\text { safeguards for } \\
\text { customers' funds. }\end{array}$ \\
\hline
\end{tabular}




\begin{tabular}{|c|c|c|c|c|c|c|c|c|}
\hline Criteria/ Country & Argentina & Brazil & Chile & Colombia & Mexico & Paraguay & Peru & Uruguay \\
\hline 3. Abuses of market power & $\begin{array}{l}2 \text { The anti-competition } \\
\text { authority (CNDC) is the } \\
\text { authority responsible for } \\
\text { enforcing competition } \\
\text { law in all sectors. In the } \\
\text { financial sector, mergers } \\
\text { have to be approved } \\
\text { also by the Central } \\
\text { Bank. The new } \\
\text { Government has made } \\
\text { an effort to make the } \\
\text { CNDC more efficient } \\
\text { and proactive }\end{array}$ & $\begin{array}{l}1 \text { Legislation does not } \\
\text { clearly set out the } \\
\text { responsibilities of the } \\
\text { BCB and the } \\
\text { competition authority } \\
\text { (Cade) as regards the } \\
\text { banking system }\end{array}$ & $\begin{array}{l}2 \text { The national competition } \\
\text { authority has the tools to } \\
\text { analyze different markets } \\
\text { and the state of } \\
\text { competition in each of } \\
\text { them and, if necessary, } \\
\text { propose to the Court the } \\
\text { imposition of sanctions } \\
\text { for practices that are } \\
\text { contrary to free } \\
\text { competition. }\end{array}$ & $\begin{array}{l}2 \text { Free competition is a } \\
\text { constitutional right. } \\
\text { SFC has powers to } \\
\text { avoid abuses of } \\
\text { market power, } \\
\text { granted by Law } 1340 \\
\text { of } 2009 \text { and Circular } \\
\text { Externa } 039 \text { of } 2011 .\end{array}$ & $\begin{array}{l}2 \text { The authority that } \\
\text { protects financial } \\
\text { consumers can order } \\
\text { changes to abusive } \\
\text { clauses in financial } \\
\text { institutions contracts. } \\
\text { The Competition } \\
\text { authority can impose } \\
\text { sanctions to avoid } \\
\text { monopolistic practices }\end{array}$ & $\begin{array}{l}2 \text { Competition Laws apply } \\
\text { to financial markets, as } \\
\text { does the National } \\
\text { Competition } \\
\text { Commission. Rules } \\
\text { prohibit agreements that } \\
\text { limit competition, } \\
\text { abusive conduct related } \\
\text { to predatory pricing, } \\
\text { rules of market } \\
\text { concentration and } \\
\text { evaluation }\end{array}$ & $\begin{array}{l}2 \text { The competition } \\
\text { authority is the } \\
\text { National Institute for } \\
\text { the Defense of } \\
\text { Competition and } \\
\text { Protection of } \\
\text { Intellectual Property } \\
\text { (INDECOPI). } \\
\text { Indecopi oversees } \\
\text { competition in any } \\
\text { sector, including the } \\
\text { financial sector. }\end{array}$ & $\begin{array}{l}1 \text { Competition could be } \\
\text { enhanced by addressing } \\
\text { legal privileges, } \\
\text { information sharing, } \\
\text { and sub-optimal } \\
\text { proprietary financial } \\
\text { infrastructure. } \text {. } 1 \text { ROU } \\
\text { has a monopoly on } \\
\text { serving the public } \\
\text { sector }\end{array}$ \\
\hline $\begin{array}{l}\text { 4. Contestability of inputs } \\
\text { and interoperability }\end{array}$ & 2 & 1 & 1.3 & 2 & 2 & 1.3 & 2 & 1.3 \\
\hline 4A. ATMs & $\begin{array}{l}2 \text { There is no evidence of } \\
\text { lack of interoperability } \\
\text { that could require } \\
\text { regulatory intervention. } \\
\text { There are two networks } \\
\text { of ATMs in Argentina: } \\
\text { Banelco and RED Link, } \\
\text { which are } \\
\text { interconnected. }\end{array}$ & $\begin{array}{l}0 \text { There is evidence of } \\
\text { lack of interoperability } \\
\text { that could require } \\
\text { regulatory } \\
\text { intervention. The } \\
\text { existence of different } \\
\text { systems and security } \\
\text { mechanisms hinder } \\
\text { the communication } \\
\text { between institutions }\end{array}$ & $\begin{array}{l}2 \text { There is no evidence of } \\
\text { lack of interoperability } \\
\text { that could require } \\
\text { regulatory intervention. } \\
\text { There are three ATM } \\
\text { networks in Chile, which } \\
\text { are interconnected, so } \\
\text { that any client can operate } \\
\text { from any ATM of any } \\
\text { bank }\end{array}$ & $\begin{array}{l}2 \text { There is no evidence } \\
\text { of lack of } \\
\text { interoperability that } \\
\text { could require } \\
\text { regulatory } \\
\text { intervention. The } \\
\text { three ATM networks } \\
\text { are interconnected, so } \\
\text { that any client can } \\
\text { operate from any } \\
\text { ATM of any bank }\end{array}$ & $\begin{array}{l}2 \text { There is no evidence } \\
\text { of lack of } \\
\text { interoperability that } \\
\text { could require } \\
\text { regulatory } \\
\text { intervention. The } \\
\text { ATM network is } \\
\text { interconnected, } \\
\text { allowing account } \\
\text { holders to withdraw } \\
\text { cash via ATMs of any } \\
\text { bank. }\end{array}$ & $\begin{array}{l}0 \text { There is evidence of lack } \\
\text { of interoperability that } \\
\text { could require regulatory } \\
\text { intervention. The two } \\
\text { ATM networks (BEPSA, } \\
\text { which serves BNF, and } \\
\text { Bancard - which serves } \\
\text { private commercial } \\
\text { banks) are not } \\
\text { interoperable. }\end{array}$ & $\begin{array}{l}2 \text { ATMs in the country } \\
\text { are largely } \\
\text { interoperable. There is } \\
\text { no evidence of lack of } \\
\text { interoperability that } \\
\text { could require } \\
\text { regulatory intervention. }\end{array}$ & $\begin{array}{l}2 \text { There has been a recent } \\
\text { regulatory intervention } \\
\text { to address previous } \\
\text { anticompetitive } \\
\text { practices. Financial } \\
\text { Inclusion Law and } \\
\text { regulations issued in } \\
2014 \text { have extended } \\
\text { interoperability to the } \\
\text { ATM and POS } \\
\text { networks. }\end{array}$ \\
\hline 4B. Agents & $\begin{array}{l}\text { n.a. There is no regulatory } \\
\text { framework for agents in } \\
\text { Argentina }\end{array}$ & $\begin{array}{l}1 \text { Regulation on agents } \\
\text { applies to institutions } \\
\text { authorized by BCB. It } \\
\text { does not deal with } \\
\text { exclusivity, although in } \\
\text { practice } \\
\text { correspondents must } \\
\text { work within the } \\
\text { separate platforms of } \\
\text { each institution. }\end{array}$ & $\begin{array}{l}0 \text { Banks can outsource } \\
\text { some services through } \\
\text { "proveedores de servicios } \\
\text { externos". No additional } \\
\text { regulation applies to non- } \\
\text { bank financial } \\
\text { institutions. Regulation in } \\
\text { place for banks does not } \\
\text { deal with interoperability. }\end{array}$ & $\begin{array}{l}2 \text { Regulated financial } \\
\text { institutions, including } \\
\text { SEDPEs, may } \\
\text { provide services } \\
\text { through } \\
\text { correspondents. } \\
\text { Exclusivity is not } \\
\text { mandated. In } \\
\text { practice, there are } \\
\text { exclusivity } \\
\text { arrangements so it is } \\
\text { not prohibited }\end{array}$ & $\begin{array}{l}2 \text { Multiple and } \\
\text { development banking } \\
\text { institutions, Socaps } \\
\text { and Sofipos are } \\
\text { allowed to operate via } \\
\text { correspondents. } \\
\text { Exclusivity is explicitly } \\
\text { permitted by the } \\
\text { regulation, although it } \\
\text { is not mandated. }\end{array}$ & $\begin{array}{l}2 \text { Banks, cooperatives and } \\
\text { non-bank e-money } \\
\text { issuers can operate } \\
\text { through agents. Agents } \\
\text { are allowed by Law to } \\
\text { operate with one or } \\
\text { more financial } \\
\text { institutions, so } \\
\text { exclusivity is not } \\
\text { mandated nor forbidden }\end{array}$ & $\begin{array}{l}2 \text { Banks, other financial } \\
\text { institutions and } \\
\text { electronic money } \\
\text { issuers are allowed to } \\
\text { operate via agents. } \\
\text { Regulations does not } \\
\text { require agent } \\
\text { exclusivity, even if it is } \\
\text { not prohibited }\end{array}$ & $\begin{array}{l}0 \text { Regulation explicitly } \\
\text { prohibits exclusivity } \\
\text { arrangements with } \\
\text { correspondents. } \\
\text { Regulation applies to } \\
\text { banks, cooperatives and } \\
\text { savings group } \\
\text { administrators. E- } \\
\text { money issuers can also } \\
\text { operate through agents. }\end{array}$ \\
\hline $\begin{array}{l}\text { 4C. Credit Reporting } \\
\text { Systems }\end{array}$ & $\begin{array}{l}2 \text { Banks, financing } \\
\text { companies, savings and } \\
\text { loans entities and credit } \\
\text { companies (Cajas de } \\
\text { crédito) are allowed to } \\
\text { access information from } \\
\text { the credit bureau and } \\
\text { the credit registry } \\
\text { online. }\end{array}$ & $\begin{array}{l}2 \text { Regulated financial } \\
\text { institutions can access } \\
\text { data on borrowers. } \\
\text { Private bureaus' data is } \\
\text { available for natural or } \\
\text { legal persons with } \\
\text { whom the borrower } \\
\text { maintains a } \\
\text { commercial/credit } \\
\text { relationship }\end{array}$ & $\begin{array}{l}2 \text { Financial Institutions can } \\
\text { access information from } \\
\text { the public registry. Data } \\
\text { contained in private } \\
\text { bureaus can only be used } \\
\text { for credit assessment, and } \\
\text { therefore can be accessed } \\
\text { by lenders. }\end{array}$ & $\begin{array}{l}2 \text { Banks and financial } \\
\text { companies are } \\
\text { allowed to access } \\
\text { information on } \\
\text { borrowers from the } \\
\text { credit bureaus. }\end{array}$ & $\begin{array}{l}2 \text { Financial institutions, } \\
\text { commercial companies } \\
\text { can access information } \\
\text { from the bureau, if } \\
\text { this borrower has } \\
\text { given its explicit } \\
\text { authorization. }\end{array}$ & $\begin{array}{l}2 \text { Banks and financial } \\
\text { companies can access } \\
\text { information on } \\
\text { borrowers from the } \\
\text { credit bureaus and in the } \\
\text { public registry, according } \\
\text { to the regulation in place. }\end{array}$ & $\begin{array}{l}2 \text { Banks and financial } \\
\text { companies can access } \\
\text { information on } \\
\text { borrowers from the } \\
\text { credit bureaus and in } \\
\text { the public registry. }\end{array}$ & $\begin{array}{l}2 \text { Banks and financial } \\
\text { companies and other } \\
\text { credit companies are } \\
\text { allowed to access } \\
\text { information on } \\
\text { borrowers from the } \\
\text { credit bureaus and in } \\
\text { the public registry, as } \\
\text { regulated in the relevant } \\
\text { legislation. }\end{array}$ \\
\hline $\begin{array}{l}\text { Competition Policies } \\
\text { Sub-Index Score }\end{array}$ & 1.7 & 1.3 & 1.8 & 1.7 & 1.8 & 1.7 & 1.6 & 1.4 \\
\hline
\end{tabular}




\section{Annex III: Supervisory Quality: Methodological Considerations}

\section{A. Original Questions and Scoring in Barth, Levine and Caprio (2005 and 2013)}

Based on their book (2005) James Barth, Gerard Caprio and Ross Levine constructed 52 indices on the quality of financial regulation and supervision. Among the indices constructed, the authors developed an index of official supervisory power to measure the degree to which a country's bank supervisory agency has the authority to take specific actions. It is based on the answers from specific survey questions:

(1) Does the supervisory agency have the right to meet with external auditors about banks?

Survey question: 5.10. Does the banking supervisor have the right to meet with the external auditors and discuss their report without the approval of the bank? a. No; b. Yes, it happens on a regular basis; $c$. Yes, it happens on an exceptional basis. Quantification: For question 5.10: $\mathrm{a}=0$; $\mathrm{b}$ or $\mathrm{c}=1$.

This survey question corresponds to Component A in our Supervisory Powers indicator.

(2) Are auditors required to communicate directly to the supervisory agency about illicit activities, fraud, or insider abuse?

Survey question: 5.9. Are auditors required to communicate directly to the supervisory agency any presumed involvement of bank directors or senior managers in illicit activities, fraud, or insider abuse? Quantification: Yes $=1 ;$ No $=0$.

This survey question corresponds to Component B in our Supervisory Powers indicator.

(3) Can supervisors take legal action against external auditors for negligence?

Survey question: 5.12(b). In cases where the supervisor identifies that the bank has received an inadequate audit, does the supervisor have the powers to take actions against ...(b) The external auditor? Quantification: Yes $=1 ; \mathrm{No}=0$

This survey question corresponds to Component C in our Supervisory Powers indicator.

(4) Can the supervisory authority force a bank to change its internal organizational structure?

Survey question: 12.3.2 Can the supervisory authority force a bank to change its internal organizational structure? Quantification: Yes $=1 ;$ No $=0$

This survey question corresponds to Component D in our Supervisory Powers indicator.

(5) Are off-balance-sheet items disclosed to supervisors? 
Survey question: 10.5(b). Do banks disclose to the supervisors ...(b) Off-balance sheet items?

Quantification: $Y e s=1 ;$ No $=0$

This survey question corresponds to Component E in our Supervisory Powers indicator.

(6) Can the supervisory agency order the bank's directors or management to set aside reserves for potential losses?

Survey question: 11.1(f) Please indicate whether the following enforcement powers are available to the supervisory agency. (f) Require banks to constitute provisions to cover actual or potential losses.

Quantification: Yes $=1 ;$ No $=0$

This survey question corresponds to Component F in our Supervisory Powers indicator.

(7) Can the supervisory agency suspend the directors' decision to distribute dividends?

Survey question: 11.1(j) Please indicate whether the following enforcement powers are available to the supervisory agency. (j). Require banks to reduce or suspend dividends to shareholders. Quantification: Yes $=1 ;$ No $=0$

This survey question corresponds to Component G in our Supervisory Powers indicator.

(8) Can the supervisory agency suspend the directors' decision to distribute bonuses, and management fees?

Survey question: 11.1(k) Please indicate whether the following enforcement powers are available to the supervisory agency. (k) Require banks to reduce or suspend bonuses and other remuneration to bank directors and managers. Quantification: Yes $=1 ; \mathrm{No}=0$

This survey question corresponds to Component H in our Supervisory Powers indicator.

(9) Can the supervisory agency supersede the rights of bank shareholders and declare a bank insolvent?

Survey question: 11.5(a) Which authority has the powers to perform the following problem bank resolution activities (a). declare insolvency? Quantification: $\mathrm{BS}=$ Bank Supervisor $=1 ; \mathrm{DIA}=$ Deposit Insurance Agency $=0.5 ; \mathrm{BR} / \mathrm{AMC}=$ Bank Restructuring or Asset Management Agency $=0.5 ; \mathrm{C}=$ Court $=0$; and OTH $=$ Other - please specify $=0$.

This survey question corresponds to Component I in our Supervisory Powers indicator.

(10)Can the supervisory agency suspend some or all ownership rights?

Survey question: 11.5(b) Which authority has the powers to perform the following problem bank resolution activities (b). Supersede shareholders' rights? Quantification: BS $=$ Bank Supervisor $=1$; DIA $=$ Deposit Insurance Agency $=0.5 ; \mathrm{BR} / \mathrm{AMC}=$ Bank Restructuring or Asset Management Agency $=0.5 ; \mathrm{C}=$ Court $=0$; and OTH $=$ Other - please specify $=0$.

This survey question corresponds to Component J in our Supervisory Powers indicator. 


\section{(11) Can the supervisory agency supersede shareholder rights, remove and replace}

management, and remove and replace directors?

Survey question: 11.5(c) Which authority has the powers to perform the following problem bank resolution activities (c). Remove and replace bank senior management and directors? Quantification: $\mathrm{BS}=$ Bank Supervisor $=1 ;$ DIA $=$ Deposit Insurance Agency $=0.5 ; \mathrm{BR} / \mathrm{AMC}=$ Bank Restructuring or Asset Management Agency $=0.5 ; \mathrm{C}=$ Court $=0$; and OTH $=$ Other please specify $=0$.

This survey question corresponds to Component $\mathrm{K}$ in our Supervisory Powers indicator.

Quantification of the index: $5.10+5.9+5.12(\mathrm{~b})+12.3 .2+10.5(\mathrm{~b})+11.1(\mathrm{f})+11.1(\mathrm{j})$ $+11.1(\mathrm{k}) * 2+11.5(\mathrm{a})+11.5(\mathrm{~b}) * 2+11.5(\mathrm{c}) * 296$

The official supervisory index ranges from zero to 14, with higher numbers indicating greater power.

96: Barth, Caprio and Levine (2013) assign more weight to some of the questions in the construction of the Official Supervisory Powers index. This explains why the scores for survey questions 11.1(k), 11.5(b) and 11(c) are multiplied by two. 


\section{B. Original and Updated Scores for the Indicators}

Source: Barth, Caprio, Levine Database

(1) Component A. Survey question 5.10 Does the banking supervisor have the right to meet with the external auditors and discuss their report without the approval of the bank?

Quantification ORIGINAL (based on 2011-2012 data)

Quantification UPDATED

(2) Component B. Survey question 5.9 Are auditors required to communicate directly to the supervisory agency any presumed involvement of bank directors or senior managers in illicit activities, fraud, or insider abuse?

Quantification ORIGINAL (based on 2011-2012 data)

Quantification UPDATED

(3) Component C. Survey question 5.12 In cases where the supervisor identifies that the bank has received an inadequate audit, does the supervisor have the powers to take actions against ...(b) the external auditor

Quantification ORIGINAL (based on 2011-2012 data) Quantification UPDATED

(4) Component D. Survey question 12.3.2 Can the supervisory authority force a bank to change its internal organizational structure?

Quantification ORIGINAL (based on 2011-2012 data) Quantification UPDATED

(5) Component E. Survey question 10.5. Do banks disclose to the supervisors ...(b) Off-balance sheet items?

Quantification ORIGINAL (based on 2011-2012 data)

Quantification UPDATED

(6) Component F. Survey question 11.1(f) Please indicate whether the following enforcement powers are a vailable to the supervisoty agency. (f) Require banks to constitute provisions to cover actual or potential losses.

Quantification ORIGINAL (based on 2011-2012 data)

Quantification UPDATED

\begin{tabular}{|c|c|c|c|c|c|c|c|}
\hline Argentina & Brazil & Chile & Colombia & Mexico & Paraguay & Peru & Uruguay \\
\hline Yes & No & Yes & Yes & Yes & Yes & Yes & Yes \\
\hline 1 & 0 & 1 & 1 & 1 & 1 & 1 & 1 \\
\hline 1 & 0 & 1 & 1 & 1 & 1 & 1 & 1 \\
\hline No & Yes & Yes & Yes & Yes & Yes & Yes & Yes \\
\hline 0 & 1 & 1 & 1 & 1 & 1 & 1 & 1 \\
\hline 0 & 1 & 1 & 1 & 1 & 1 & 1 & 1 \\
\hline Yes & Yes & Yes & Yes & Yes & Yes & Yes & Yes \\
\hline 1 & 1 & 1 & 1 & 1 & 1 & 1 & 1 \\
\hline 1 & 1 & 1 & 1 & 1 & 1 & 1 & 1 \\
\hline No & Yes & Yes & Yes & Yes & Yes & Yes & Yes \\
\hline 0 & 1 & 1 & 1 & 1 & 1 & 1 & 1 \\
\hline 0 & 1 & 1 & 1 & 1 & 1 & 1 & 1 \\
\hline Yes & Yes & Yes & Yes & Yes & Yes & Yes & Yes \\
\hline 1 & 1 & 1 & 1 & 1 & 1 & 1 & 1 \\
\hline 1 & 1 & 1 & 1 & 1 & 1 & 1 & 1 \\
\hline Yes & Yes & Yes & Yes & --- & Yes & Yes & Yes \\
\hline 1 & 1 & 1 & 1 & 1 & 1 & 1 & 1 \\
\hline 1 & 1 & 1 & 1 & 1 & 1 & 1 & 1 \\
\hline
\end{tabular}


(7) Component G. Survey question 11.1 Please indicate whether the following enforcement powers are a vailable to the supervisory agency. (j). Require banks to reduce or suspend dividends to shareholders.

Quantification ORIGINAL (based on 2011-2012 data)

Quantification UPDATED

(8) Component H. Survey question 11.1 Please indicate whether the following enforcement powers are a vailable to the supervisory agency. (k) Require banks to reduce or suspend bonuses and other remuneration to bank directors and managers

Quantification ORIGINAL (based on 2011-2012 data)

Quantification UPDATED

(9) Component I. Survey question 11.5(a) Which authority has the powers to perform the following problem bank resolution activities (a). declare insolvency?

Quantification ORIGINAL (based on 2011-2012 data)

Quantification UPDATED

(10) Component J. Survey question 11.5(b) Which authority has the powers to

perform the following problem bank resolution activities (b). Supersede Bank Supervisor

shareholders' tights?

Quantification ORIGINAL (based on 2011-2012 data)

Quantification UPDATED

(11) Component $K$ Survey question 11.5(c) Which authority has the powers to

perform the following problem bank resolution activities (c). Remove and replace Bank Supervisor

bank senior management and directors?

Quantification ORIGINAL (based on 2011-2012 data)

Quantification UPDATED

Official Supervisory Power Index ORGINAL - BASED ON 2011-2012 DATA) Scale 0-14

Official Supervisory Power Index UPDATED - Scale 0-14

The Sub-Index
1. Supervisory Powers (re-scaled)
Political independence of the financial regulator (scale 0-2) Question 2.1.2 in the Global Microscope: Is the financial regulator politically independent?

2. Independence of the Supervisor

\begin{tabular}{|c|c|c|c|c|c|c|c|}
\hline No & Yes & Yes & No & Yes & Yes & Yes & Yes \\
\hline 0 & 1 & 1 & 0 & 1 & 1 & 1 & 1 \\
\hline 1 & 1 & 1 & 0 & 1 & 1 & 1 & 1 \\
\hline No & Yes & Yes & No & Yes & Yes & Yes & Yes \\
\hline 0 & 1 & 1 & 0 & 1 & 1 & 1 & 1 \\
\hline 0 & 1 & 1 & 0 & 1 & 1 & 1 & 1 \\
\hline Bank Supervisor & $\begin{array}{c}\text { Bank } \\
\text { Supervisor }\end{array}$ & $\begin{array}{c}\text { Bank } \\
\text { Supervisor }\end{array}$ & $\begin{array}{c}\text { Bank } \\
\text { Supervisor }\end{array}$ & $\begin{array}{c}\text { Deposit } \\
\text { Insurance } \\
\text { Agency }\end{array}$ & $\begin{array}{c}\text { BANCO } \\
\text { CENTRAL }\end{array}$ & $\begin{array}{c}\text { Bank } \\
\text { Supervisor }\end{array}$ & Bank Supervisor \\
\hline 1 & 1 & 1 & 1 & 1 & 0 & 1 & 1 \\
\hline 1 & 1 & 1 & 1 & 1 & 1 & 1 & 1 \\
\hline Bank Supervisor & $\begin{array}{c}\text { Bank } \\
\text { Supervisor }\end{array}$ & $\begin{array}{c}\text { Bank } \\
\text { Supervisor }\end{array}$ & Court & $\begin{array}{c}\text { Deposit } \\
\text { Insurance } \\
\text { Agency }\end{array}$ & $\begin{array}{c}\text { BANCO } \\
\text { CENTRAL }\end{array}$ & $\begin{array}{c}\text { Bank } \\
\text { Supervisor }\end{array}$ & Bank Supervisor \\
\hline 1 & 1 & 1 & 0 & 0.5 & 0 & 1 & 1 \\
\hline 1 & 1 & 1 & 0 & 0.5 & 1 & 1 & 1 \\
\hline Bank Supervisor & $\begin{array}{c}\text { Bank } \\
\text { Supervisor }\end{array}$ & $\begin{array}{c}\text { Bank } \\
\text { Supervisor }\end{array}$ & $\begin{array}{c}\text { Bank } \\
\text { Supervisor }\end{array}$ & $\begin{array}{c}\text { Deposit } \\
\text { Insurance } \\
\text { Agency }\end{array}$ & $\begin{array}{c}\text { BANCO } \\
\text { CENTRAL }\end{array}$ & $\begin{array}{c}\text { Bank } \\
\text { Supervisor }\end{array}$ & Bank Supervisor \\
\hline 1 & 1 & 1 & 1 & 0.5 & 0 & 1 & 1 \\
\hline 1 & 1 & 1 & 1 & 0.5 & 1 & 1 & 1 \\
\hline 9 & 13 & 14 & 9 & 12 & 9 & 14 & 14 \\
\hline 10 & 13 & 14 & 9 & 12 & 14 & 14 & 14 \\
\hline 1.4 & 1.9 & 2 & 1.3 & 1.7 & 2 & 2 & 2 \\
\hline 0 & 1 & 1 & 1 & 1 & 2 & 2 & 1 \\
\hline 0 & 1 & 1 & 1 & 1 & 2 & 2 & 1 \\
\hline 0.7 & 1.5 & 1.5 & 1.2 & 1.4 & 2 & 2 & 1.5 \\
\hline
\end{tabular}

Supervisory Quality sub-Index 
Annex IV: Supervisory Quality: Summary of Regulatory Findings

\begin{tabular}{|c|c|c|c|c|c|c|c|c|}
\hline Criteria/ Country & Argentina & Brazil & Chile & Colombia & Mexico & Paraguay & Peru & Uruguay \\
\hline 1. Regulatory framework & 1.4 & 1.9 & 2 & 1.3 & 1.7 & 2 & 2 & 2 \\
\hline $\begin{array}{l}\text { 1A. Meeting with } \\
\text { external auditors }\end{array}$ & $\begin{array}{l}2 \text { The banking supervisor } \\
\text { can meet with external } \\
\text { auditors and discuss } \\
\text { thir report without } \\
\text { approval of the bank }\end{array}$ & $\begin{array}{l}0 \text { The banking } \\
\text { supervisor cannot } \\
\text { meet with external } \\
\text { auditors and discuss } \\
\text { their report without } \\
\text { approval of the bank }\end{array}$ & $\begin{array}{l}2 \text { The banking supervisor } \\
\text { can meet with external } \\
\text { auditors and discuss their } \\
\text { report without approval } \\
\text { of the bank }\end{array}$ & $\begin{array}{l}2 \text { The banking supervisor } \\
\text { can meet with external } \\
\text { auditors and discuss } \\
\text { their report without } \\
\text { approval of the bank }\end{array}$ & $\begin{array}{l}2 \text { The banking } \\
\text { supervisor can meet } \\
\text { with external auditors } \\
\text { and discuss their } \\
\text { report without } \\
\text { approval of the bank }\end{array}$ & $\begin{array}{l}2 \text { The banking supervisor } \\
\text { can meet with external } \\
\text { auditors and discuss their } \\
\text { report without approval of } \\
\text { the bank }\end{array}$ & $\begin{array}{l}2 \text { The banking supervisor } \\
\text { can meet with external } \\
\text { auditors and discuss } \\
\text { their report without } \\
\text { approval of the bank }\end{array}$ & $\begin{array}{l}2 \text { The banking supervisor } \\
\text { can meet with external } \\
\text { auditors and discuss } \\
\text { their report without } \\
\text { approval of the bank }\end{array}$ \\
\hline $\begin{array}{l}\text { 1B. Be informed } \\
\text { about illicit activities, } \\
\text { fraud, insider abuse }\end{array}$ & $\begin{array}{l}0 \text { Auditors are not } \\
\text { required to } \\
\text { communicate directly to } \\
\text { the supervisory agency } \\
\text { presumed involvement } \\
\text { of bank directors/ } \\
\text { senior managers in illicit } \\
\text { activities, fraud, or } \\
\text { insider abuse }\end{array}$ & $\begin{array}{l}2 \text { Auditors are required } \\
\text { to communicate } \\
\text { directly to the } \\
\text { supervisory agency } \\
\text { presumed involvement } \\
\text { of bank directors/ } \\
\text { senior managers in } \\
\text { illicit activities, fraud, } \\
\text { or insider abuse }\end{array}$ & $\begin{array}{l}2 \text { Auditors are required to } \\
\text { communicate directly to } \\
\text { the supervisory agency } \\
\text { presumed involvement of } \\
\text { bank directors/ senior } \\
\text { managers in illicit } \\
\text { activities, fraud, or insider } \\
\text { abuse. }\end{array}$ & $\begin{array}{l}2 \text { Auditors are required } \\
\text { to communicate } \\
\text { directly to the } \\
\text { supervisory agency } \\
\text { presumed involvement } \\
\text { of bank directors/ } \\
\text { senior managers in } \\
\text { illicit activities, fraud, } \\
\text { or insider abuse }\end{array}$ & $\begin{array}{l}2 \text { Auditors are required } \\
\text { to communicate } \\
\text { directly to the } \\
\text { supervisory agency } \\
\text { presumed involvement } \\
\text { of bank directors/ } \\
\text { senior managers in } \\
\text { illicit activities, fraud, } \\
\text { or insider abuse }\end{array}$ & $\begin{array}{l}2 \text { Auditors are required to } \\
\text { communicate directly to } \\
\text { the supervisory agency } \\
\text { presumed involvement of } \\
\text { bank directors/ senior } \\
\text { managers in illicit } \\
\text { activities, fraud, or insider } \\
\text { abuse }\end{array}$ & $\begin{array}{l}2 \text { Auditors are required } \\
\text { to communicate } \\
\text { directly to the } \\
\text { supervisory agency } \\
\text { presumed involvement } \\
\text { of bank directors/ } \\
\text { senior managers in } \\
\text { illicit activities, fraud, } \\
\text { or insider abuse }\end{array}$ & $\begin{array}{l}2 \text { Auditors are required to } \\
\text { communicate directly } \\
\text { to the supervisory } \\
\text { agency presumed } \\
\text { involvement of bank } \\
\text { directors/ senior } \\
\text { managers in illicit } \\
\text { activities, fraud, or } \\
\text { insider abuse. }\end{array}$ \\
\hline $\begin{array}{l}\text { 1C. Act against } \\
\text { external auditors }\end{array}$ & $\begin{array}{l}2 \text { The supervisor can take } \\
\text { actions against the } \\
\text { external auditor in cases } \\
\text { where the supervisor } \\
\text { identifies that the bank } \\
\text { has received an } \\
\text { inadequate audit. }\end{array}$ & $\begin{array}{l}2 \text { The supervisor can } \\
\text { take actions against } \\
\text { the external auditor in } \\
\text { cases where the } \\
\text { supervisor identifies } \\
\text { that the bank has } \\
\text { received an inadequate } \\
\text { audit }\end{array}$ & $\begin{array}{l}2 \text { The supervisor can take } \\
\text { actions against the } \\
\text { external auditor in cases } \\
\text { where the supervisor } \\
\text { identifies that the bank } \\
\text { has received an } \\
\text { inadequate audit. }\end{array}$ & $\begin{array}{l}2 \text { The supervisor can take } \\
\text { actions against the } \\
\text { external auditor in } \\
\text { cases where the } \\
\text { supervisor identifies } \\
\text { that the bank has } \\
\text { received an inadequate } \\
\text { audit }\end{array}$ & $\begin{array}{l}2 \text { The supervisor can } \\
\text { take actions against } \\
\text { the external auditor in } \\
\text { cases where the } \\
\text { supervisor identifies } \\
\text { that the bank has } \\
\text { received an inadequate } \\
\text { audit }\end{array}$ & $\begin{array}{l}2 \text { The supervisor can take } \\
\text { actions against the external } \\
\text { auditor in cases where the } \\
\text { supervisor identifies that } \\
\text { the bank has received an } \\
\text { inadequate audit }\end{array}$ & $\begin{array}{l}2 \text { The supervisor can } \\
\text { take actions against the } \\
\text { external auditor in } \\
\text { cases where the } \\
\text { supervisor identifies } \\
\text { that the bank has } \\
\text { received an inadequate } \\
\text { audit }\end{array}$ & $\begin{array}{l}2 \text { The supervisor can take } \\
\text { actions against the } \\
\text { external auditor in cases } \\
\text { where the supervisor } \\
\text { identifies that the bank } \\
\text { has received an } \\
\text { inadequate audit }\end{array}$ \\
\hline $\begin{array}{l}\text { 1D. Change } \\
\text { organizational } \\
\text { structure of banks }\end{array}$ & $\begin{array}{l}0 \text { The supervisory } \\
\text { authority cannot force a } \\
\text { bank to change its } \\
\text { internal organizational } \\
\text { structure }\end{array}$ & $\begin{array}{l}2 \text { The supervisory } \\
\text { authority can force a } \\
\text { bank to change its } \\
\text { internal organizational } \\
\text { structure }\end{array}$ & $\begin{array}{l}2 \text { The supervisory authority } \\
\text { can force a bank to } \\
\text { change its internal } \\
\text { organizational structure }\end{array}$ & $\begin{array}{l}2 \text { The supervisory } \\
\text { authority can force a } \\
\text { bank to change its } \\
\text { internal organizational } \\
\text { structure }\end{array}$ & $\begin{array}{l}2 \text { The supervisory } \\
\text { authority can force a } \\
\text { bank to change its } \\
\text { internal organizational } \\
\text { structure }\end{array}$ & $\begin{array}{l}2 \text { The supervisory authority } \\
\text { can force a bank to change } \\
\text { its internal organizational } \\
\text { structure }\end{array}$ & $\begin{array}{l}2 \text { The supervisory } \\
\text { authority can force a } \\
\text { bank to change its } \\
\text { internal organizational } \\
\text { structure }\end{array}$ & $\begin{array}{l}2 \text { The supervisory } \\
\text { authority can force a } \\
\text { bank to change its } \\
\text { internal organizational } \\
\text { structure }\end{array}$ \\
\hline $\begin{array}{l}\text { 1E. Disclosure of off- } \\
\text { balance sheet items }\end{array}$ & $\begin{array}{l}2 \text { Off-balance-sheet items } \\
\text { are disclosed to } \\
\text { supervisors }\end{array}$ & $\begin{array}{l}2 \text { Off-balance-sheet } \\
\text { items are disclosed to } \\
\text { supervisors }\end{array}$ & $\begin{array}{l}2 \text { Off-balance-sheet items } \\
\text { are disclosed to } \\
\text { supervisors }\end{array}$ & $\begin{array}{l}2 \text { Off-balance-sheet } \\
\text { items are disclosed to } \\
\text { supervisors }\end{array}$ & $\begin{array}{l}2 \text { Off-balance-sheet } \\
\text { items are disclosed to } \\
\text { supervisors }\end{array}$ & $\begin{array}{l}2 \text { Off-balance-sheet items } \\
\text { are disclosed to } \\
\text { supervisors }\end{array}$ & $\begin{array}{l}2 \text { Off-balance-sheet } \\
\text { items are disclosed to } \\
\text { supervisors }\end{array}$ & $\begin{array}{l}2 \text { Off-balance-sheet items } \\
\text { are disclosed to } \\
\text { supervisors }\end{array}$ \\
\hline $\begin{array}{l}\text { 1F. Impose } \\
\text { provisioning } \\
\text { requirements }\end{array}$ & $\begin{array}{l}2 \text { The supervisory agency } \\
\text { can require banks to } \\
\text { constitute provisions to } \\
\text { cover losses }\end{array}$ & $\begin{array}{l}2 \text { The supervisory } \\
\text { agency can require } \\
\text { banks to constitute } \\
\text { provisions to cover } \\
\text { losses }\end{array}$ & $\begin{array}{l}2 \text { The supervisory agency } \\
\text { can require banks to } \\
\text { constitute provisions to } \\
\text { cover losses }\end{array}$ & $\begin{array}{l}2 \text { The supervisory agency } \\
\text { can require banks to } \\
\text { constitute provisions to } \\
\text { cover losses }\end{array}$ & $\begin{array}{l}2 \text { The supervisory } \\
\text { agency can require } \\
\text { banks to constitute } \\
\text { provisions to cover } \\
\text { losses }\end{array}$ & $\begin{array}{l}2 \text { The supervisory agency } \\
\text { can require banks to } \\
\text { constitute provisions to } \\
\text { cover losses }\end{array}$ & $\begin{array}{l}2 \text { The supervisory agency } \\
\text { can require banks to } \\
\text { constitute provisions to } \\
\text { cover losses }\end{array}$ & $\begin{array}{l}2 \text { The supervisory agency } \\
\text { can require banks to } \\
\text { constitute provisions to } \\
\text { cover losses }\end{array}$ \\
\hline $\begin{array}{l}\text { 1G. Suspend } \\
\text { dividends }\end{array}$ & $\begin{array}{l}2 \text { The supervisory agency } \\
\text { can require banks to } \\
\text { reduce or suspend } \\
\text { dividends to } \\
\text { shareholders. Updated } \\
\text { on the basis of Art. } 34\end{array}$ & $\begin{array}{l}2 \text { The supervisory } \\
\text { agency can require } \\
\text { banks to reduce or } \\
\text { suspend dividends to } \\
\text { shareholders }\end{array}$ & $\begin{array}{l}2 \text { The supervisory agency } \\
\text { can require banks to } \\
\text { reduce or suspend } \\
\text { dividends to shareholders }\end{array}$ & $\begin{array}{l}0 \text { The supervisory agency } \\
\text { cannot require banks to } \\
\text { reduce or suspend } \\
\text { dividends to } \\
\text { shareholders }\end{array}$ & $\begin{array}{l}2 \text { The supervisory } \\
\text { agency can require } \\
\text { banks to reduce or } \\
\text { suspend dividends to } \\
\text { shareholders }\end{array}$ & $\begin{array}{l}2 \text { The supervisory agency } \\
\text { can require banks to } \\
\text { reduce or suspend } \\
\text { dividends to shareholders }\end{array}$ & $\begin{array}{l}2 \text { The supervisory agency } \\
\text { can require banks to } \\
\text { reduce or suspend } \\
\text { dividends to } \\
\text { shareholders }\end{array}$ & $\begin{array}{l}2 \text { The supervisory agency } \\
\text { can require banks to } \\
\text { reduce or suspend } \\
\text { dividends to } \\
\text { shareholders }\end{array}$ \\
\hline
\end{tabular}




\begin{tabular}{|c|c|c|c|c|c|c|c|c|}
\hline Criteria/ Country & Argentina & Brazil & Chile & Colombia & Mexico & Paraguay & Peru & Uruguay \\
\hline $\begin{array}{l}\text { 1H. Suspend bonuses } \\
\text { and management fees }\end{array}$ & $\begin{array}{l}0 \text { The supervisory agency } \\
\text { cannot require banks to } \\
\text { reduce bonuses and } \\
\text { other remuneration to } \\
\text { bank directors and } \\
\text { managers }\end{array}$ & $\begin{array}{l}2 \text { The supervisory } \\
\text { agency can require } \\
\text { banks to reduce or } \\
\text { suspend bonuses and } \\
\text { other remuneration to } \\
\text { bank directors and } \\
\text { managers. }\end{array}$ & $\begin{array}{l}2 \text { The supervisory agency } \\
\text { can require banks to } \\
\text { reduce or suspend } \\
\text { bonuses and other } \\
\text { remuneration to bank } \\
\text { directors and managers. }\end{array}$ & $\begin{array}{l}0 \text { The supervisory agency } \\
\text { cannot require banks to } \\
\text { reduce bonuses and } \\
\text { other remuneration to } \\
\text { bank directors and } \\
\text { managers }\end{array}$ & $\begin{array}{l}2 \text { The supervisory } \\
\text { agency can require } \\
\text { banks to reduce or } \\
\text { suspend bonuses and } \\
\text { other remuneration to } \\
\text { bank directors and } \\
\text { managers. }\end{array}$ & $\begin{array}{l}2 \text { The supervisory agency } \\
\text { can require banks to } \\
\text { reduce or suspend bonuses } \\
\text { and other remuneration to } \\
\text { bank directors and } \\
\text { managers. }\end{array}$ & $\begin{array}{l}2 \text { The supervisory agency } \\
\text { can require banks to } \\
\text { reduce or suspend } \\
\text { bonuses and other } \\
\text { remuneration to bank } \\
\text { directors and managers. }\end{array}$ & $\begin{array}{l}2 \text { The supervisory agency } \\
\text { can require banks to } \\
\text { reduce or suspend } \\
\text { bonuses and other } \\
\text { remuneration to bank } \\
\text { directors and managers. }\end{array}$ \\
\hline $\begin{array}{l}\text { 1I. Declare bank } \\
\text { insolvency }\end{array}$ & $\begin{array}{l}2 \text { The banking supervisor } \\
\text { can declare bank } \\
\text { insolvency }\end{array}$ & $\begin{array}{l}2 \text { The banking } \\
\text { supervisor can declare } \\
\text { bank insolvency }\end{array}$ & $\begin{array}{l}2 \text { The banking supervisor } \\
\text { can declare bank } \\
\text { insolvency }\end{array}$ & $\begin{array}{l}2 \text { The banking supervisor } \\
\text { can declare bank } \\
\text { insolvency }\end{array}$ & $\begin{array}{l}2 \text { The banking } \\
\text { supervisor can declare } \\
\text { bank insolvency }\end{array}$ & $\begin{array}{l}2 \text { The banking supervisor } \\
\text { can declare bank } \\
\text { insolvency. Updated on } \\
\text { the basis of Art. } 12 \text { of Law } \\
2.334\end{array}$ & $\begin{array}{l}2 \text { The banking supervisor } \\
\text { can declare bank } \\
\text { insolvency }\end{array}$ & $\begin{array}{l}2 \text { The banking supervisor } \\
\text { can declare bank } \\
\text { insolvency }\end{array}$ \\
\hline $\begin{array}{l}\text { 1J. Supersede } \\
\text { shareholders' rights }\end{array}$ & $\begin{array}{l}2 \text { The banking supervisor } \\
\text { can supersede } \\
\text { shareholders' rights. }\end{array}$ & $\begin{array}{l}2 \text { The banking } \\
\text { supervisor can } \\
\text { supersede } \\
\text { shareholders' rights }\end{array}$ & $\begin{array}{l}2 \text { The banking supervisor } \\
\text { can supersede } \\
\text { shareholders' rights. }\end{array}$ & $\begin{array}{l}0 \text { Neither the bank } \\
\text { supervisor, the deposit } \\
\text { insurance agency or a } \\
\text { bank restructuring can } \\
\text { supersede shareholders' } \\
\text { rights }\end{array}$ & $\begin{array}{l}1 \text { The deposit insurance } \\
\text { agency has the power } \\
\text { to supersede } \\
\text { shareholders' rights }\end{array}$ & $\begin{array}{l}2 \text { The banking supervisor } \\
\text { can supersede } \\
\text { shareholders' rights. } \\
\text { Updated based on Art. } 16 \\
\text { of Law } 2.334\end{array}$ & $\begin{array}{l}2 \text { The banking supervisor } \\
\text { can supersede } \\
\text { shareholders' rights. }\end{array}$ & $\begin{array}{l}2 \text { The banking supervisor } \\
\text { can supersede } \\
\text { shareholders' rights. }\end{array}$ \\
\hline $\begin{array}{l}\text { 1K. Replace managers } \\
\text { and directors }\end{array}$ & $\begin{array}{l}2 \text { The banking supervisor } \\
\text { can remove and replace } \\
\text { managers and directors }\end{array}$ & $\begin{array}{l}2 \text { The banking } \\
\text { supervisor can remove } \\
\text { and replace managers } \\
\text { and directors }\end{array}$ & $\begin{array}{l}2 \text { The banking supervisor } \\
\text { can remove and replace } \\
\text { managers and directors }\end{array}$ & $\begin{array}{l}2 \text { The banking supervisor } \\
\text { can remove and replace } \\
\text { managers and directors }\end{array}$ & $\begin{array}{l}1 \text { The deposit insurance } \\
\text { agency can remove } \\
\text { and replace managers } \\
\text { and directors }\end{array}$ & $\begin{array}{l}2 \text { The banking supervisor } \\
\text { can remove and replace } \\
\text { managers and directors. } \\
\text { Updated based on Art. } 16 \\
\text { of Law } 2.334\end{array}$ & $\begin{array}{l}2 \text { The banking supervisor } \\
\text { can remove and replace } \\
\text { managers and directors }\end{array}$ & $\begin{array}{l}2 \text { The banking supervisor } \\
\text { can remove and replace } \\
\text { managers and directors }\end{array}$ \\
\hline $\begin{array}{l}\text { 2. Independence of } \\
\text { the Supervisor }\end{array}$ & 0 & 1 & 1 & 1 & 1 & 2 & 2 & 1 \\
\hline $\begin{array}{l}\text { 2A. Independence of } \\
\text { the Supervisor }\end{array}$ & $\begin{array}{l}0 \text { According to EIU } \\
\text { (2016), the financial } \\
\text { regulator is often } \\
\text { influenced by political } \\
\text { dynamics. The BCRA } \\
\text { Charter, latest amended } \\
\text { in } 2012 \text { establishes that } \\
\text { Board Members are } \\
\text { appointed by the } \\
\text { Executive for } 6 \text { years, } \\
\text { while the } \\
\text { superintendent of } \\
\text { supervision is appointed } \\
\text { for } 3 \text { years. There are } \\
\text { no regulatory provisions } \\
\text { regarding reasons for } \\
\text { removal of the } \\
\text { superintendent and on } \\
\text { the need to make the } \\
\text { decision public }\end{array}$ & $\begin{array}{l}1 \text { According to EIU } \\
\text { (2016), the financial } \\
\text { regulator is generally } \\
\text { independent from } \\
\text { political influence. The } \\
\text { Law does not require } \\
\text { "due cause" for the } \\
\text { removal of the } \\
\text { Governor, and it does } \\
\text { not provide for a fixed } \\
\text { term. A constitutional } \\
\text { amendment to } \\
\text { strengthen the BCB's } \\
\text { operational autonomy } \\
\text { was proposed in 2016, } \\
\text { but it does not deal } \\
\text { with the Bank's } \\
\text { independence }\end{array}$ & $\begin{array}{l}1 \text { According to EIU (2016), } \\
\text { the financial regulator is } \\
\text { generally independent } \\
\text { from political influence. } \\
\text { According to the General } \\
\text { Banking Law, SBIF is } \\
\text { autonomous, with full } \\
\text { legal capacity, regulated } \\
\text { by that same Law. The } \\
\text { Superintendent is } \\
\text { appointed by the } \\
\text { President of Chile with } \\
\text { no fixed term, and may be } \\
\text { dismissed without cause. }\end{array}$ & $\begin{array}{l}1 \text { According to EIU } \\
\text { (2016), the financial } \\
\text { regulator is generally } \\
\text { independent from } \\
\text { political influence. } \\
\text { Traditionally, } \\
\text { legislation did not set a } \\
\text { fixed term for the } \\
\text { superintendent, who } \\
\text { could be removed at } \\
\text { any time by the } \\
\text { president. A } 2015 \text { Law } \\
\text { defined a fix term and } \\
\text { requested removal with } \\
\text { "due cause". The } \\
\text { decision of appointing } \\
\text { the Superintendent } \\
\text { remains with the } \\
\text { President. }\end{array}$ & $\begin{array}{l}1 \text { According to EIU } \\
\text { (2016), the financial } \\
\text { regulator is generally } \\
\text { independent from } \\
\text { political influence. } \\
\text { Legally, there are no } \\
\text { explicit tenors for the } \\
\text { appointment of the } \\
\text { President of the } \\
\text { CNBV. CNBV senior } \\
\text { staff can be removed } \\
\text { at the discretion of the } \\
\text { President of the } \\
\text { CNBV. The CNBV is } \\
\text { dependent on the } \\
\text { Ministry of Finance } \\
\text { for its budget }\end{array}$ & $\begin{array}{l}2 \text { According to EIU (2016), } \\
\text { the financial regulator is } \\
\text { always independent from } \\
\text { political influence. } \\
\text { Although the term of the } \\
\text { Superintendent of Banks is } \\
\text { not fixed by law, the } \\
\text { Charter of the Central } \\
\text { Bank defines the reasons } \\
\text { that might lead to the } \\
\text { removal of the supervisor. }\end{array}$ & $\begin{array}{l}2 \text { According to EIU } \\
\text { (2016), the financial } \\
\text { regulator is always } \\
\text { independent from } \\
\text { political influence. The } \\
\text { SBS is an independent } \\
\text { agency that manages its } \\
\text { own budget. } \\
\text { Furthermore, the } \\
\text { Superintendent is } \\
\text { appointed for a fixed } \\
\text { term of } 5 \text { years. This is } \\
\text { regulated under the } \\
\text { Political Constitution } \\
\text { of Peru and the } \\
\text { General Law on the } \\
\text { Financial System }\end{array}$ & $\begin{array}{l}1 \text { According to EIU } \\
\text { (2016), the financial } \\
\text { regulator is generally } \\
\text { independent from } \\
\text { political influence. } \\
\text { There is no clarity in } \\
\text { the law about the scope } \\
\text { of the SSF's technical } \\
\text { and operational } \\
\text { autonomy. The BCU } \\
\text { Law does not specify } \\
\text { grounds for the } \\
\text { removal of Directors } \\
\text { and of the } \\
\text { Superintendent, nor the } \\
\text { need to make public the } \\
\text { reasons for such } \\
\text { decision. }\end{array}$ \\
\hline $\begin{array}{l}\text { Supervisory Quality Sub-Index } \\
\text { Score }\end{array}$ & 0.7 & 1.5 & 1.5 & 1.2 & 1.4 & 2 & 2 & 1.5 \\
\hline
\end{tabular}




\section{Annex V: Regulatory Frameworks for Simplified Accounts}

\begin{tabular}{|c|c|c|c|}
\hline Country & Product & Regulator & Applicable Legislation \\
\hline Argentina & Caja de ahorros & $\begin{array}{l}\text { Central Bank of the } \\
\text { Republic (BCRA) }\end{array}$ & $\begin{array}{l}\text { BCRA Comunication "A" } 5127 \\
\text { Resolution UIF } 121 / 11 \text { and amendments }\end{array}$ \\
\hline Brazil & $\begin{array}{l}\text { Simplified account } \\
\text { (Contas simples) }\end{array}$ & $\begin{array}{l}\text { Banco Central do } \\
\text { Brasil }\end{array}$ & $\begin{array}{l}\text { Resolutions CMN } 3211 \text { (2004) and } 3881 \text { (2010), and } \\
\text { Circular No } 3731 \text { (2014) }\end{array}$ \\
\hline Chile & $\begin{array}{l}\text { Simplified accounts } \\
\text { are not a regulated } \\
\text { product }\end{array}$ & SBIF & $\begin{array}{l}\text { Rules on sight accounts. Compendium of Financial } \\
\text { Rules of the Central Bank. Chapter III B.1.1. and } \\
\text { Chapters 1-14, 2-1, 2-2 and 2-4 RAN }\end{array}$ \\
\hline \multirow[t]{2}{*}{ Colombia } & $\begin{array}{l}\text { Savings account of } \\
\text { simplified opening } \\
\text { regime (Cuenta de } \\
\text { aborro de trámite } \\
\text { simplificado, CATS) }\end{array}$ & $\begin{array}{l}\text { Superintendencia } \\
\text { Financiera (SFC) } \\
\text { Finance Ministry }\end{array}$ & $\begin{array}{l}\text { Circulars } 053 \text { (2009) and } 013 \text { (2013) } \\
\text { Circular Básica Jurídica, Title IV, Chapter IV }\end{array}$ \\
\hline & $\begin{array}{l}\text { Electronic Savings } \\
\text { Account (Cuenta de } \\
\text { ahorro electronica, } \\
\text { CAE) }\end{array}$ & $\begin{array}{l}\text { Superintendencia } \\
\text { Financiera (SFC) } \\
\text { Finance Ministry }\end{array}$ & $\begin{array}{l}\text { Decree } 2555 \text { (2010) } \\
\text { Circular } 08 \text { (2009) } \\
\text { Circular Básica Jurídica, Title IV, Chapter IV }\end{array}$ \\
\hline Mexico & $\begin{array}{l}\text { Simplified File } \\
\text { Accounts of Level 1, } \\
2 \text { or } 3 \\
\text { (Cuentas de Expediente } \\
\text { Simplificado) }\end{array}$ & $\begin{array}{l}\text { Bank of Mexico } \\
\text { Banking and } \\
\text { Securities } \\
\text { Commission } \\
\text { (CNBV) } \\
\text { Ministry of } \\
\text { Finance and } \\
\text { Public Credit } \\
\text { (SHCP) }\end{array}$ & $\begin{array}{l}\text { Credit Institutions Law - LIC - (art. 115) and General } \\
\text { provisions referred to in art. } 115 \text { of the LIC } \\
\text { Banxico Circulars 03/2012, 22/2010 and 14/2011 }\end{array}$ \\
\hline Paraguay & $\begin{array}{l}\text { Basic Savings } \\
\text { Account (Cuenta } \\
\text { Básica de Ahorro, } \\
\text { CBA) }\end{array}$ & $\begin{array}{l}\text { Central Bank of } \\
\text { Paraguay (BCP) }\end{array}$ & Resolution 25, Act 51. July 18 $18^{\text {th }}, 2013$ \\
\hline Peru & $\begin{array}{l}\text { Basic account } \\
\text { (Cuentas básicas) }\end{array}$ & $\begin{array}{l}\text { Superintendencia de } \\
\text { Banca, Seguros y } \\
\text { AFP (SBS) }\end{array}$ & Resolutions SBS 2018/ 2011, 2660/2015 and 8181/2012 \\
\hline \multirow[t]{2}{*}{ Uruguay } & $\begin{array}{l}\text { Basic Savings } \\
\text { Account (Cuenta } \\
\text { Básica de Ahorro) }\end{array}$ & $\begin{array}{l}\text { Central Bank of } \\
\text { Uruguay (BCU) }\end{array}$ & $\begin{array}{l}\text { BCU Circular 2152/2013 } \\
\text { Law 19.210/2014 on Financial Inclusion } \\
\text { BCU Circular 2201/2014 }\end{array}$ \\
\hline & $\begin{array}{l}\text { Simplified accounts } \\
\text { for small enterprises }\end{array}$ & $\begin{array}{l}\text { Central Bank of } \\
\text { Uruguay (BCU) }\end{array}$ & $\begin{array}{l}\text { Law } 19.210 / 2014 \text { on Financial Inclusion } \\
\text { BCU Circular } 2201 / 2014\end{array}$ \\
\hline
\end{tabular}




\section{Annex VI: Simplified Accounts: Summary of Regulatory Findings}

\begin{tabular}{|c|c|c|c|c|c|c|c|c|}
\hline Criteria/ Country & Argentina & Brazil & Chile & Colombia & Mexico & Paraguay & Peru & Uruguay \\
\hline \multicolumn{9}{|c|}{ 1. Minimum regulatory standards } \\
\hline 1. Regulatory framework & 2 & 2 & $\begin{array}{l}0 \text { Simplified accounts are } \\
\text { not a regulated product in } \\
\text { Chile, but the public bank } \\
\text { BancoEstado offers a } \\
\text { similar product } \\
\text { (CuentaRUT). }\end{array}$ & 2 & 2 & 2 & 2 & 2 \\
\hline 2. Clients & 0 Only natural persons & 0 Only natural persons & $\begin{array}{l}0 \text { CuentaRUT is only } \\
\text { available for natural } \\
\text { persons }\end{array}$ & 0 Only natural persons & $\begin{array}{l}2 \text { Account levels } 1 \text { and } 2 \\
\text { can be offered to } \\
\text { natural and legal } \\
\text { persons }\end{array}$ & 0 Only natural persons & 0 Only natural persons & $\begin{array}{l}2 \text { Law } 19.210 / 2014 \text { creates } \\
\text { the simplified accounts } \\
\text { for small enterprises }\end{array}$ \\
\hline 3. Providers & $\begin{array}{l}2 \text { Commercial banks, } \\
\text { financing companies, } \\
\text { cajas de crédito, and } \\
\text { savings and loans } \\
\text { institutions. }\end{array}$ & $\begin{array}{l}0 \text { Simplified accounts } \\
\text { can only be offered by } \\
\text { banks }\end{array}$ & $\begin{array}{l}0 \text { CuentaRUT can only be } \\
\text { provided by banks. } \\
\text { Currently, only } \\
\text { BancoEstado offers it }\end{array}$ & $\begin{array}{l}1 \text { Only credit institutions, } \\
\text { but not credit } \\
\text { cooperatives }\end{array}$ & $\begin{array}{l}2 \text { Only banks and } \\
\text { Socaps, but not } \\
\text { Sofipos. }\end{array}$ & $\begin{array}{l}0 \text { Only banks and financing } \\
\text { companies, but not } \\
\text { cooperatives. }\end{array}$ & $\begin{array}{l}2 \text { All institutions that are } \\
\text { authorized to take } \\
\text { deposits }\end{array}$ & $\begin{array}{l}1 \text { Simplified opening } \\
\text { procedures apply to both } \\
\text { banks and cooperatives. }\end{array}$ \\
\hline $\begin{array}{l}\text { 4. Permitted channels for the } \\
\text { provision of simplified } \\
\text { accounts }\end{array}$ & $\begin{array}{l}1 \text { Simplified accounts can } \\
\text { be opened in person or } \\
\text { via electronic means. } \\
\text { Agents are not } \\
\text { regulated. }\end{array}$ & $\begin{array}{l}1 \text { Opening via agents is } \\
\text { permitted, but remote } \\
\text { opening is not. }\end{array}$ & $\begin{array}{l}1 \text { CuentaRUT can be } \\
\text { opened by electronic } \\
\text { means }\end{array}$ & $\begin{array}{l}2 \text { Simplified accounts can } \\
\text { be opened via agents } \\
\text { and by electronic means }\end{array}$ & $\begin{array}{l}2 \text { Remote opening is } \\
\text { permitted for accounts } \\
\text { of level } 1 \text { and } 2 \text {, while } \\
\text { agents can open } \\
\text { accounts of level 1,2 } \\
\text { and } 3 .\end{array}$ & $\begin{array}{l}2 \text { Accounts can be opened } \\
\text { in a branch, correspondent } \\
\text { or via any electronic mean } \\
\text { (phone, internet, or other) }\end{array}$ & $\begin{array}{l}2 \text { Under the simplified } \\
\text { regime in the } \\
\text { Transparency } \\
\text { Regulation, remote } \\
\text { opening is permitted. } \\
\text { Agents can also open } \\
\text { them }\end{array}$ & $\begin{array}{l}0 \text { Correspondents can only } \\
\text { receive information and } \\
\text { documentation, not } \\
\text { open the accounts. } \\
\text { Remote opening is not } \\
\text { permitted }\end{array}$ \\
\hline $\begin{array}{l}\text { 5. Identification and } \\
\text { verification requirements for } \\
\text { the provision of simplified } \\
\text { accounts. }\end{array}$ & $\begin{array}{l}2 \text { Information } \\
\text { requirements for } \\
\text { opening the account } \\
\text { are minimum and } \\
\text { feasible for any } \\
\text { individual }\end{array}$ & $\begin{array}{l}2 \text { Information } \\
\text { requirements for } \\
\text { opening the account } \\
\text { are minimum and } \\
\text { feasible for any } \\
\text { individual }\end{array}$ & $\begin{array}{l}2 \text { Information requirements } \\
\text { for opening the account } \\
\text { are minimum and feasible } \\
\text { for any individual. }\end{array}$ & $\begin{array}{l}2 \text { Information } \\
\text { requirements for } \\
\text { opening the account are } \\
\text { minimum and feasible } \\
\text { for any individual }\end{array}$ & $\begin{array}{l}2 \text { Information } \\
\text { requirements for } \\
\text { opening the account } \\
\text { are minimum and } \\
\text { feasible for any } \\
\text { individual }\end{array}$ & $\begin{array}{l}2 \text { Information requirements } \\
\text { for opening the account } \\
\text { are minimum and feasible } \\
\text { for any individual }\end{array}$ & $\begin{array}{l}2 \text { Information } \\
\text { requirements for } \\
\text { opening the account } \\
\text { are minimum and } \\
\text { feasible for any } \\
\text { individual }\end{array}$ & $\begin{array}{l}2 \text { Information } \\
\text { requirements for } \\
\text { opening the account are } \\
\text { minimum and feasible } \\
\text { for any individual }\end{array}$ \\
\hline 6. Transactional limits & $\begin{array}{l}1 \text { Balance cannot exceed } \\
25 \text { minimum wages } \\
\text { (USD 12400), and the } \\
\text { monthly volume of } \\
\text { transactions, } 4 \\
\text { minimum wages (USD } \\
\text { 2000) } \\
\text { No graduation is } \\
\text { envisaged in case the } \\
\text { above limits are } \\
\text { breached. }\end{array}$ & $\begin{array}{l}2 \text { Balance and monthly } \\
\text { volume of } \\
\text { transactions cannot } \\
\text { exceed R } \$ 3000(880 \\
\text { USD). If this limit is } \\
\text { breached, the account } \\
\text { can be converted into } \\
\text { a standard account } \\
\text { provided additional } \\
\text { KYC requirements } \\
\text { are fulfilled. }\end{array}$ & $\begin{array}{l}1 \text { Maximum balance: } 3 \\
\text { million pesos (4800 USD). } \\
\text { Maximum volume of } \\
\text { deposits: } 2 \text { million pesos. } \\
\text { Additional daily limits to } \\
\text { deposits and transactions } \\
\text { are set. No graduation is } \\
\text { envisaged in case the } \\
\text { above limits are breached. }\end{array}$ & $\begin{array}{l}1 \text { Sum of monthly debit } \\
\text { operations: } 3 \text { minimum } \\
\text { wages ( } 700 \text { USD) } \\
\text { Maximum balance: } 8 \\
\text { minimum monthly } \\
\text { wages (1800 USD). No } \\
\text { graduation is envisaged } \\
\text { in case the above limits } \\
\text { are breached. }\end{array}$ & $\begin{array}{l}2 \text { Monthly volume of } \\
\text { deposits for levels } 1,2 \\
\text { and 3: } 750 \text { UDIS (255 } \\
\text { USD), } 3000 \text { UDIS } \\
\text { (1022 USD) and } \\
10.000 \text { UDIS (3406 } \\
\text { USD). If limits are } \\
\text { breached, account } \\
\text { graduation is } \\
\text { envisaged, provided } \\
\text { additional KYC } \\
\text { requirements are } \\
\text { fulfilled). }\end{array}$ & $\begin{array}{l}2 \text { Sum of monthly deposits: } \\
\text { up to six minimum wages } \\
\text { (approximately USD } \\
\text { 1897). Clients that wish to } \\
\text { operate above this limit } \\
\text { need to comply with the } \\
\text { requirements of traditional } \\
\text { accounts }\end{array}$ & $\begin{array}{l}1 \text { Balance cannot exceed } \\
\text { S/. } 2000 \text { (627 USD), } \\
\text { daily deposits S/. } 1000 \\
\text { (313 USD), and the } \\
\text { sum of monthly } \\
\text { transactions S/. } 4000 \\
\text { (1254). If this limit is } \\
\text { breached, the bank will } \\
\text { proceed to close the } \\
\text { account }\end{array}$ & $\begin{array}{l}2 \text { Balance: } 831 \text { USD } \\
\text { Monthly deposit: } 2851 \\
\text { USD. If these limits are } \\
\text { breached, the institution } \\
\text { must apply additional } \\
\text { due diligence procedures } \\
\text { and inform the client } \\
\text { that he ceases to operate } \\
\text { under the simplified } \\
\text { regime. }\end{array}$ \\
\hline $\begin{array}{l}\text { 7. Limits to the number of } \\
\text { accounts }\end{array}$ & $\begin{array}{l}1 \text { Only one simplified } \\
\text { account in the system } \\
\text { per person }\end{array}$ & $\begin{array}{l}1 \text { Only one simplified } \\
\text { account in the system } \\
\text { per person }\end{array}$ & $\begin{array}{l}2 \text { Only one CuentaRUT per } \\
\text { individual }\end{array}$ & $\begin{array}{l}2 \text { Only one simplified } \\
\text { account per person in } \\
\text { each institution }\end{array}$ & $\begin{array}{l}1 \text { Regulation does not set } \\
\text { limits to the number of } \\
\text { accounts, but } \\
\text { transactional limits are } \\
\text { set per client in each } \\
\text { institution }\end{array}$ & $\begin{array}{l}1 \text { Only one simplified } \\
\text { account per entity and a } \\
\text { maximum of two in the } \\
\text { system. Institutions must } \\
\text { have procedures to verify } \\
\text { this is satisfied. }\end{array}$ & $\begin{array}{l}1 \text { Only one simplified } \\
\text { account per client and } \\
\text { institution. Maximum } \\
\text { of four in the financial } \\
\text { system. }\end{array}$ & $\begin{array}{l}1 \text { Only one simplified } \\
\text { account per client in the } \\
\text { system. Institutions must } \\
\text { inform the SSF of the } \\
\text { opening and closure of } \\
\text { these accounts. }\end{array}$ \\
\hline
\end{tabular}




\begin{tabular}{|c|c|c|c|c|c|c|c|c|}
\hline Criteria/ Country & Argentina & Brazil & Chile & Colombia & Mexico & Paraguay & Peru & Uruguay \\
\hline 8. Fees and commissions & $\begin{array}{l}0 \text { Institutions cannot } \\
\text { charge fees for opening, } \\
\text { maintaining or } \\
\text { operating with the } \\
\text { accounts. Institutions } \\
\text { must offer for free a } \\
\text { debit card, and all } \\
\text { operations via ATM or } \\
\text { internet banking. }\end{array}$ & $\begin{array}{l}\text { 0 Institutions cannot } \\
\text { charge fees for } \\
\text { opening, maintaining } \\
\text { or operating with the } \\
\text { accounts, except } \\
\text { when more than four } \\
\text { withdrawals or } \\
\text { deposits are } \\
\text { performed each } \\
\text { month }\end{array}$ & $\begin{array}{l}2 \text { No commissions for } \\
\text { opening or maintaining } \\
\text { the account, but there are } \\
\text { transaction fees. }\end{array}$ & $\begin{array}{l}2 \text { Regulation does not } \\
\text { intervene nor regulate } \\
\text { the fees and } \\
\text { commissions }\end{array}$ & $\begin{array}{l}0 \text { There are restrictions } \\
\text { on fees charged for the } \\
\text { provision of some } \\
\text { services. In particular, } \\
\text { institutions cannot } \\
\text { charge for money } \\
\text { withdrawals in their } \\
\text { own ATM network }\end{array}$ & $\begin{array}{l}0 \text { Free-cost monthly } \\
\text { transactions: deposits in } \\
\text { their own ATMs, } \\
\text { correspondents or } \\
\text { mobile/electronic } \\
\text { banking, four money } \\
\text { withdrawals from their } \\
\text { own ATMs or } \\
\text { correspondents, two } \\
\text { balance enquiries. } \\
\text { Institutions can charge } \\
\text { fees for additional } \\
\text { transactions }\end{array}$ & $\begin{array}{l}2 \text { Regulation does not } \\
\text { intervene nor regulate } \\
\text { the fees and } \\
\text { commissions }\end{array}$ & $\begin{array}{l}2 \text { Regulation does not } \\
\text { intervene nor regulate } \\
\text { the fees and } \\
\text { commissions }\end{array}$ \\
\hline $\begin{array}{l}\text { 8A. Adjusted fees and } \\
\text { commissions (for } \\
\text { Competition policies) }\end{array}$ & 0 & 0 & 2 & 2 & 0 & 0 & 2 & 2 \\
\hline Score Set 1 & 1.1 & 1 & 1 & 1.5 & 1.6 & 1.1 & 1.5 & 1.5 \\
\hline \multicolumn{9}{|c|}{ 2. Additional government efforts } \\
\hline $\begin{array}{l}\text { 1. Additional government } \\
\text { efforts }\end{array}$ & $\begin{array}{l}2 \text { Payment of subsidies } \\
\text { and Governments' } \\
\text { transfer programs is } \\
\text { done through cajas de } \\
\text { aborros (simplified } \\
\text { accounts) }\end{array}$ & $\begin{array}{l}2 \text { Payment of the } \\
\text { conditional transfer } \\
\text { program Bolsa Familia } \\
\text { can be done through a } \\
\text { simplified account at } \\
\text { Caixa Economica. }\end{array}$ & $\begin{array}{l}2 \text { Program "Cbile Cuenta" } \\
\text { includes the option to } \\
\text { request the opening of a } \\
\text { CuentaRUT at the } \\
\text { moment of applying to } \\
\text { any social benefit. }\end{array}$ & $\begin{array}{l}2 \text { Payment of the } \\
\text { conditional transfer } \\
\text { program Más Familias } \\
\text { en Acción can be done } \\
\text { through CATS, CAEs } \\
\text { or electronic deposits. }\end{array}$ & $\begin{array}{l}1 \text { Payment of the } \\
\text { conditional transfer } \\
\text { program Prospera can } \\
\text { be done through a level } \\
2 \text { account at Bansefi. } \\
\text { However, it seems that } \\
\text { this effort is only able } \\
\text { to reach people in } \\
\text { urban areas. }\end{array}$ & $\begin{array}{l}2 \text { Payment of the } \\
\text { conditional transfer } \\
\text { program Tekoporã can be } \\
\text { done through simplified } \\
\text { accounts at Banco Nacional } \\
\text { de Fomento or through an } \\
\text { electronic wallet }\end{array}$ & $\begin{array}{l}2 \text { Payment of the } \\
\text { conditional transfer } \\
\text { program Juntos can be } \\
\text { done through } \\
\text { simplified accounts at } \\
\text { Banco de la Nación. } \\
\text { This effort seems to } \\
\text { reach both the formal } \\
\text { and informal sector. }\end{array}$ & $\begin{array}{l}0 \text { Simplified accounts } \\
\text { cannot be used to receive } \\
\text { social security benefits or } \\
\text { any form social of } \\
\text { assistance. There is a } \\
\text { specific product for this } \\
\text { Cuentas para pago de } \\
\text { prestaciones sociales, which } \\
\text { only allows deposits } \\
\text { from Government } \\
\text { payments,withdrawals at } \\
\text { branches, and payments } \\
\text { by direct debit. }\end{array}$ \\
\hline $\begin{array}{l}\text { 1A. Adjusted additional } \\
\text { government efforts (for } \\
\text { Crowding out) }\end{array}$ & $\begin{array}{l}2 \text { Payment of social } \\
\text { benefits may be } \\
\text { received at an account } \\
\text { of any bank. }\end{array}$ & $\begin{array}{l}0.5 \text { There seems to be a } \\
\text { crowding out of other } \\
\text { products or } \\
\text { institutions, as the } \\
\text { Law establishes that } \\
\text { Bolsa Familia payments } \\
\text { are made through } \\
\text { Caixa. }\end{array}$ & $\begin{array}{l}2 \text { Payment of social } \\
\text { benefits might be } \\
\text { received at any account of } \\
\text { any bank or in cash. }\end{array}$ & $\begin{array}{l}2 \text { The tender is open to } \\
\text { all supervised } \\
\text { institutions. The } \\
\text { individual can choose } \\
\text { the payment method } \\
\text { and institutions may } \\
\text { define the product as } \\
\text { CATS or CAE or e- } \\
\text { money. }\end{array}$ & $\begin{array}{l}0 \text { There seems to be a } \\
\text { crowding out of other } \\
\text { products or institutions. } \\
\text { The allocation of this } \\
\text { service with Bansefi did } \\
\text { not follow an open } \\
\text { tender. }\end{array}$ & $\begin{array}{l}0.5 \text { There is a crowding out of } \\
\text { other products or } \\
\text { institutions, according to a } \\
\text { World Bank 2014 Report } \\
\text { on regulations for financial } \\
\text { inclusion in Paraguay. }\end{array}$ & $\begin{array}{l}0.5 \text { There seems to be a } \\
\text { crowding out of other } \\
\text { products or institutions }\end{array}$ & 0 \\
\hline Score Set 2 & 2 & 0.5 & 2 & 2 & 0 & 0.5 & 0.5 & 0 \\
\hline $\begin{array}{l}\text { Simplified Accounts Sub- } \\
\text { Index Score }\end{array}$ & 1.5 & 0.8 & 1.4 & 1.7 & 1 & 0.9 & 1.1 & 0.9 \\
\hline
\end{tabular}




\section{Annex VII: Regulatory Frameworks for Electronic Money}

\section{Country New regulated figure Regulator Applicable legislation}

\begin{tabular}{|c|c|c|c|}
\hline Argentina & -- & -- & -- \\
\hline Brazil & $\begin{array}{l}\text { Payment institution } \\
\text { (Instituiçao de pagamento) }\end{array}$ & $\begin{array}{l}\text { Banco Central do } \\
\text { Brasil }\end{array}$ & $\begin{array}{l}\text { Law 12.865/2013 } \\
\text { Resolutions CMN } 4282 \text { and 4283, Circulars 3680- } \\
3693,3704,3705,3721,3735,3765\end{array}$ \\
\hline Chile & $\begin{array}{l}\text { Issuers of payment means } \\
\text { against provision of funds }\end{array}$ & SBIF & $\begin{array}{l}\text { Compendium of Financial Rules of the Central } \\
\text { Bank. Chapter III. J. } 3 . \\
\text { Law } 20950 \text { of } 2016\end{array}$ \\
\hline Colombia & $\begin{array}{l}\text { Institution specialzed on } \\
\text { electronic payments and } \\
\text { deposis (SEDPE - } \\
\text { Sociedades Especializada } \\
\text { en Depósitos y Pagos } \\
\text { Electrónicos) }\end{array}$ & $\begin{array}{l}\text { Superintendencia } \\
\text { Financiera (SFC) }\end{array}$ & $\begin{array}{l}\text { Law } 1735 \text { on Financial Inclusion Regulation } \\
\text { 1491/2015 on SEDPEs } \\
\text { Circular Básica Jurídica, Part II Title V, Chapter IV }\end{array}$ \\
\hline Mexico & -- & -- & -- \\
\hline Paraguay & $\begin{array}{l}\text { Entity of electronic } \\
\text { payments (EMPE - } \\
\text { Entidad de Medio de Pago } \\
\text { Electrónico) }\end{array}$ & $\begin{array}{l}\text { Central Bank of } \\
\text { Paraguay }\end{array}$ & $\begin{array}{l}\text { Resolution 6, March 2014. Regulation on electronic } \\
\text { payments } \\
\text { SEPRELAD Resolution 349/2013 }\end{array}$ \\
\hline Peru & $\begin{array}{l}\text { Institution issuer of } \\
\text { electronic money (EEDE } \\
\text { - Empresa Emisora de } \\
\text { Dinero Electrónico) }\end{array}$ & $\begin{array}{l}\text { Superintendencia } \\
\text { de Banca, Seguros } \\
\text { y AFP (SBS) }\end{array}$ & $\begin{array}{l}\text { Law } 29985 / 2013 \text { on electronic money } \\
\text { Regulation on the Law 29985/2013 } \\
\text { Resolutions 6283, } 6284 \text { and } 6285 \text { (2013) } \\
\text { Resolution 465/2017 }\end{array}$ \\
\hline Uruguay & $\begin{array}{l}\text { Institution issuer of } \\
\text { electronic money (IEDE - } \\
\text { Institución Emisora de } \\
\text { Dinero Electrónico) }\end{array}$ & $\begin{array}{l}\text { Central Bank of } \\
\text { Uruguay (BCU) }\end{array}$ & $\begin{array}{l}\text { Law } 19.210 / 2014 \text { on Financial Inclusion, modified } \\
\text { by Law 19.478/2017 } \\
\text { BCU Circular } 2201 / 2014 \\
\text { Circular } 2198\end{array}$ \\
\hline
\end{tabular}




\section{Annex VIII: Electronic Money: Summary of Regulatory Findings}

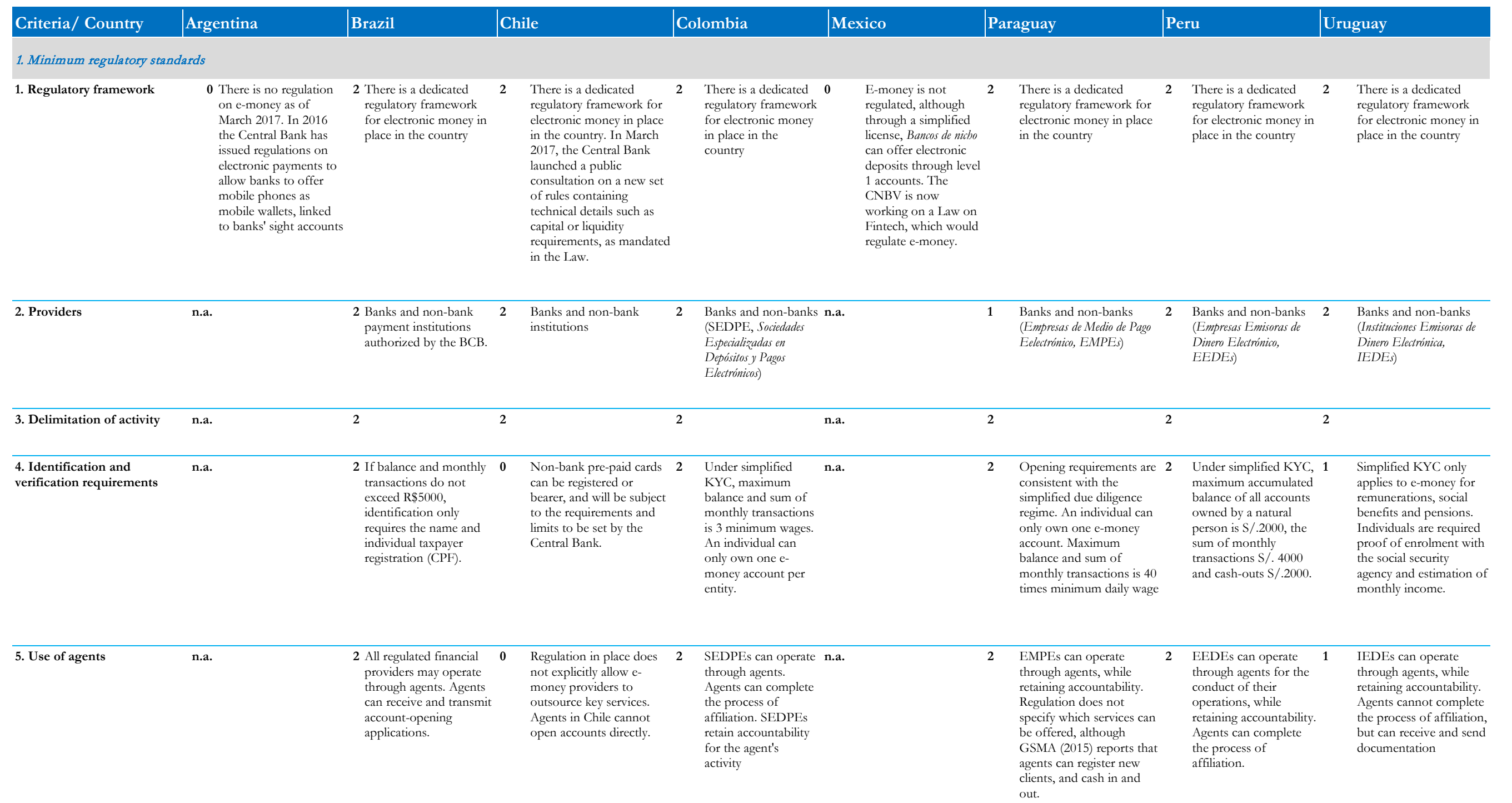




\begin{tabular}{|c|c|c|c|c|c|c|c|c|c|}
\hline Criteria/Country & Argentina & & Brazil & Chile & Colombia & Mexico & Paraguay & Peru & Uruguay \\
\hline 6. Protection of funds & n.a. & & 2 & 1.3 & 2 & n.a. & 1.3 & 2 & 1.3 \\
\hline 6A. Liquidity & -- & & $\begin{array}{l}2 \text { An amount equivalent } \\
\text { to the outstanding e- } \\
\text { money balance must } \\
\text { be kept in payment } \\
\text { accounts, and funds } \\
\text { invested at accounts at } \\
\text { the Central Bank or } \\
\text { government bonds. }\end{array}$ & $\begin{array}{l}2 \text { The owner of a prepaid } \\
\text { card has the right to cash } \\
\text { out the outstanding } \\
\text { balance at any time. } \\
\text { Funds received by the } \\
\text { issuer must be held in } \\
\text { financial instruments } \\
\text { determined by the Central } \\
\text { Bank }\end{array}$ & $\begin{array}{l}2 \text { SEDPEs are required to } \\
\text { deposit all customer funds in } \\
\text { a demand deposit account in } \\
\text { the Central Bank or another } \\
\text { financial institution }\end{array}$ & 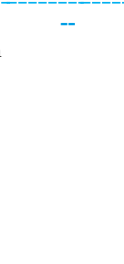 & $\begin{array}{l}2 \text { EMPEs must set aside } \\
\text { an amount equivalent to } \\
100 \% \text { of the outstanding } \\
\text { e-money liabilities. } \\
\text { These funds can only be } \\
\text { deposited in accounts at } \\
\text { an institution authorized } \\
\text { by the BCP. }\end{array}$ & $\begin{array}{l}2100 \% \text { of outstanding e- } \\
\text { money liabilities must be } \\
\text { set aside in accounts at } \\
\text { financial institutions rated } \\
\text { A+; government bonds } \\
\text { and instruments issued by } \\
\text { the Central Bank (up to } \\
30 \% \text { of total funds) }\end{array}$ & $\begin{array}{l}2 \text { Funds must be placed in } \\
\text { bank accounts or } \\
\text { government instruments. } \\
\text { IEDEs must guarantee } \\
\text { that the value of funds } \\
\text { set aside is at least equal } \\
\text { to the amount of e- } \\
\text { money liabilities. }\end{array}$ \\
\hline $\begin{array}{l}\text { 6B. Protection against } \\
\text { issuer's insolvency }\end{array}$ & -- & 2 & $\begin{array}{l}\text { Funds are not to be } \\
\text { used to meet any } \\
\text { obligation of the } \\
\text { payment institution, } \\
\text { even in the event of } \\
\text { the institution's } \\
\text { bankruptcy. }\end{array}$ & $\begin{array}{l}2 \text { Customer funds are not } \\
\text { to be used to meet any } \\
\text { obligation of the issuer, } \\
\text { even in the event of the } \\
\text { institution's bankruptcy. }\end{array}$ & $\begin{array}{l}2 \text { No specific provision on } \\
\text { ring-fencing. Funds are } \\
\text { covered by the Deposit } \\
\text { Guarantee Scheme directly. }\end{array}$ & -- & $\begin{array}{l}2 \text { The regulation requires } \\
\text { EMPEs to establish a trust } \\
\text { to protect customer funds } \\
\text { against losses in case of } \\
\text { insolvency of the issuer }\end{array}$ & $\begin{array}{l}2 \text { The regulation requires } \\
\text { EMPEs to establish a } \\
\text { trust to protect } \\
\text { customer funds against } \\
\text { losses in case of } \\
\text { insolvency }\end{array}$ & $\begin{array}{l}2 \text { Funds are not to be used } \\
\text { to meet any obligation of } \\
\text { the payment institution, } \\
\text { even in the event of the } \\
\text { issuer's bankruptcy. }\end{array}$ \\
\hline $\begin{array}{l}\text { 6C. Protection against } \\
\text { bank's insolvency }\end{array}$ & -- & 2 & $\begin{array}{l}\text { Initial (R\$2million) } \\
\text { and on-going capital } \\
\text { requirements ( } 2 \% \text { of } \\
\text { balance of electronic } \\
\text { currency issued). }\end{array}$ & $\begin{array}{l}0 \text { Regulation in place does } \\
\text { not deal with this issue, } \\
\text { further details might be } \\
\text { included in future Central } \\
\text { Bank regulation }\end{array}$ & $\begin{array}{l}2 \text { Funds are guaranteed by } \\
\text { Fogafin. Regulation sets } \\
\text { initial (COP } 5.846 \text { billion) } \\
\text { and on-going ( } 2 \% \text { of } \\
\text { outstanding e-money } \\
\text { liabilities) capital } \\
\text { requirements }\end{array}$ & - & $\begin{array}{l}0 \text { Initial and on-going capital } \\
\text { requirements are not } \\
\text { imposed. } \\
\text { No other mechanism is in } \\
\text { place to protect customer } \\
\text { funds against insolvency } \\
\text { of the bank. }\end{array}$ & $\begin{array}{l}2 \text { Regulation sets initial } \\
\text { (S/.2268519) and on- } \\
\text { going }(2 \% \text { of } \\
\text { outstanding e-money } \\
\text { liabilities) capital } \\
\text { requirements }\end{array}$ & $\begin{array}{l}0 \text { No initial or on-going } \\
\text { capital requirements. } \\
\text { No other mechanism is } \\
\text { in place to protect } \\
\text { customer funds against } \\
\text { insolvency of the bank. }\end{array}$ \\
\hline 7. Interoperability & n.a. & 2 & $\begin{array}{l}\text { Interoperability is a } \\
\text { long term goal, but } \\
\text { not mandated from } \\
\text { inception. Rules focus } \\
\text { on ensuring non- } \\
\text { discriminatory access } \\
\text { to inputs and } \\
\text { infrastructure. }\end{array}$ & $\begin{array}{l}1 \text { Regulation in place does } \\
\text { not include any provision } \\
\text { on interoperability }\end{array}$ & $\begin{array}{l}1 \text { Regulation does not include } \\
\text { any provision on } \\
\text { interoperability }\end{array}$ & n.a. & $\begin{array}{l}2 \text { Regulation requires } \\
\text { EMPEs to comply with } \\
\text { rules on interoperability to } \\
\text { be determined by the } \\
\text { BCP. }\end{array}$ & $\begin{array}{l}2 \text { Interoperability can be } \\
\text { regulated by the SBS in } \\
\text { the future. Although it } \\
\text { has not been } \\
\text { mandated, it is essential } \\
\text { for the recently } \\
\text { developed "Peruvian } \\
\text { Model" }\end{array}$ & $\begin{array}{l}1 \text { Regulation does not } \\
\text { include any provision on } \\
\text { interoperability }\end{array}$ \\
\hline 8. Fees and commissions & n.a. & 2 & $\begin{array}{l}\text { BCB can issue rules } \\
\text { on this at any time, } \\
\text { but has not done it so } \\
\text { far. }\end{array}$ & $\begin{array}{l}2 \text { Law in place does not set } \\
\text { restrictions, but the } \\
\text { Central Bank may issue } \\
\text { rules }\end{array}$ & $\begin{array}{l}2 \text { Regulation does not impose } \\
\text { restrictions on fees and } \\
\text { commissions }\end{array}$ & n.a. & $\begin{array}{l}0 \text { Regulation prohibits } \\
\text { charging fees for } \\
\text { converting the funds back } \\
\text { to cash }\end{array}$ & $\begin{array}{l}2 \text { Regulation does not } \\
\text { impose restrictions on } \\
\text { fees and commissions }\end{array}$ & $\begin{array}{l}0 \text { No commissions for } \\
\text { opening,maintenance, } \\
\text { balance enquiries and } \\
\text { withdrawals (up to 5) }\end{array}$ \\
\hline $\begin{array}{l}\text { 8A. Adjusted fees and } \\
\text { Commissions (for } \\
\text { competition Policies) }\end{array}$ & - & 2 & & 2 & 2 & -- & 0 & 2 & 0 \\
\hline Score Set 1 & 0 & & 2 & 1.3 & 1.9 & 0 & 1.5 & 2 & 1.3 \\
\hline
\end{tabular}




\begin{tabular}{|c|c|c|c|c|c|c|c|c|}
\hline Criteria/ Country & Argentina & Brazil & Chile & Colombia & Mexico & Paraguay & Peru & Uruguay \\
\hline \multicolumn{9}{|c|}{ 2. Additional government efforts } \\
\hline $\begin{array}{l}\text { 1. Additional government } \\
\text { efforts }\end{array}$ & n.a. & $\begin{array}{l}0 \text { Caixa Economica } \\
\text { intends to offer an } \\
\text { electronic wallet for } \\
\text { the payment of social } \\
\text { benefits as Bolsa } \\
\text { Familia, but this } \\
\text { product has not been } \\
\text { launched yet. }\end{array}$ & $\begin{array}{l}0 \text { No additional efforts } \\
\text { have been undertaken. } \\
\text { Payments of conditional } \\
\text { transfer programs are } \\
\text { mainly done through } \\
\text { checks, deposits at bank } \\
\text { account or in cash. }\end{array}$ & $\begin{array}{l}2 \text { Social programs (Más } \\
\text { Familias en Acción) can be } \\
\text { paid through simplified } \\
\text { savings accounts (CATS), } \\
\text { electronic savings } \\
\text { accounts (CAEs) and } \\
\text { electronics deposits. }\end{array}$ & n.a. & $\begin{array}{l}2 \text { Payment of the } \\
\text { conditional transfer } \\
\text { program Tekoporã can } \\
\text { be done through } \\
\text { simplified accounts at } \\
\text { Banco Nacional de } \\
\text { Fomento or through an } \\
\text { electronic wallet }\end{array}$ & $\begin{array}{l}1 \text { Payment of social } \\
\text { benefits cannot be } \\
\text { made through } \\
\text { electronic money yet, } \\
\text { although it is a mid- } \\
\text { term objective. Some } \\
\text { taxes can be paid } \\
\text { through BIM. }\end{array}$ & $\begin{array}{l}2 \text { Financial Inclusion Law } \\
\text { establishes that } \\
\text { workers, pensioners or } \\
\text { other beneficiaries can } \\
\text { receive their salary, } \\
\text { pension or benefit in an } \\
\text { e-money instrument. }\end{array}$ \\
\hline $\begin{array}{l}\text { 1A. Adjusted additional -- } \\
\text { gov. efforts (for Crowding } \\
\text { out) }\end{array}$ & & 0 & 0 & $\begin{array}{l}2 \text { There is no crowding out } \\
\text { of other products or } \\
\text { institutions. }\end{array}$ & -- & $\begin{array}{l}2 \text { There is no crowding out } \\
\text { of other products or } \\
\text { institutions. }\end{array}$ & 1 & $\begin{array}{l}2 \text { There does not seem to } \\
\text { be a crowding out. }\end{array}$ \\
\hline Score Set 2 & n.a. & 0 & 0 & 2 & 0 & 2 & 1 & 2 \\
\hline E-Money Sub-Index Score & 0 & 1.2 & 0.8 & 1.9 & 0 & 1.7 & 1.6 & 1.6 \\
\hline
\end{tabular}




\section{Annex IX: Regulatory Frameworks for Correspondents}

\begin{tabular}{|c|c|c|}
\hline Country & Denomination & Applicable legislation \\
\hline Argentina & -- & -- \\
\hline Brazil & $\begin{array}{l}\text { Correspondents } \\
\text { (Correspondentes) }\end{array}$ & $\begin{array}{l}\text { Resolution CMN } 3.954 \text { of } 2011 \text { and subsequent amendments } \\
\text { Resolution CMN } 3110 \text { of } 2003\end{array}$ \\
\hline Chile & $\begin{array}{l}\text { Proveedores de servicios } \\
\text { externos }\end{array}$ & Compendium on Updated Norms (RAN) - Chapter 20-7 \\
\hline Colombia & $\begin{array}{l}\text { Banking } \\
\text { correspondents } \\
\text { (Corresponsales } \\
\text { bancarios) }\end{array}$ & $\begin{array}{l}\text { Decrees } 2555 \text { of } 2010,2671 \text { of } 2013 \text { and } 2233 \text { of } 2006 \\
\text { Decree } 3965 \text { of } 2006 \\
\text { Decree } 086 \text { of } 2008\end{array}$ \\
\hline Mexico & $\begin{array}{l}\text { Banking } \\
\text { correspondents or } \\
\text { Comisionistas }\end{array}$ & $\begin{array}{l}\text { Credit Institutions Law - LIC } \\
\text { Circular Unica de Bancos } \\
\text { Law on Socaps and Sofipos, Law on Popular Savings and Loans } \\
\text { Sector }\end{array}$ \\
\hline Paraguay & $\begin{array}{l}\text { Non bank } \\
\text { correspondents } \\
\text { (Corresponsales no } \\
\text { bancarios) }\end{array}$ & Resolution BCP 1 of 2011, Act 70 \\
\hline Peru & Cajeros corresponsales & Resolution SBS 4798/ 2015 \\
\hline Uruguay & $\begin{array}{l}\text { Correspondents } \\
\text { (Corresponsales) }\end{array}$ & $\begin{array}{l}\text { Compilation of Regulatory and Control Norms for the Financial } \\
\text { System, Book I, Chapter VI - BIS }\end{array}$ \\
\hline
\end{tabular}




\section{Annex X: Correspondents: Summary of Regulatory Findings}

\begin{tabular}{|c|c|c|c|c|c|c|c|c|}
\hline Criteria/ Country & Argentina & Brazil & Chile & Colombia & Mexico & Paraguay & Peru & Uruguay \\
\hline 1. Regulatory framework & $\begin{array}{l}0 \text { There is no legislation in } \\
\text { force to regulate } \\
\text { financial institutions } \\
\text { operations through } \\
\text { agents or } \\
\text { correspondents. }\end{array}$ & $\begin{array}{l}2 \text { Regulation in place } \\
\text { applies to banks and } \\
\text { other institutions } \\
\text { authorized by the } \\
\text { Central Bank of } \\
\text { Brazil, including } \\
\text { payment institutions. }\end{array}$ & $\begin{array}{l}1 \text { This figure has not been } \\
\text { regulated. Banks can } \\
\text { outsource some services } \\
\text { through "proveedores de } \\
\text { servicios externos". No } \\
\text { additional regulation } \\
\text { applies to non-bank } \\
\text { financial institutions }\end{array}$ & $\begin{array}{l}2 \text { Regulated financial } \\
\text { institutions, including } \\
\text { SEDPEs, may provide } \\
\text { services through } \\
\text { correspondents. }\end{array}$ & $\begin{array}{l}2 \text { Multiple and } \\
\text { development banking } \\
\text { institutions, Socaps } \\
\text { and Sofipos are } \\
\text { allowed to operate via } \\
\text { correspondents. }\end{array}$ & $\begin{array}{l}1 \text { The law is applicable for } \\
\text { financial institutions. } \\
\text { Regulation on e- money } \\
\text { allows issuers to operate } \\
\text { through agents. } \\
\text { Cooperatives can operate } \\
\text { through different channels } \\
\text { including agencies. }\end{array}$ & $\begin{array}{l}2 \text { Regulation applies to } \\
\text { regulated financial } \\
\text { institutions, including } \\
\text { issuers of electronic } \\
\text { money (EEDEs) }\end{array}$ & $\begin{array}{l}2 \text { Regulation applies to } \\
\text { banks, cooperatives and } \\
\text { savings group } \\
\text { administrators. E- } \\
\text { money issuers can also } \\
\text { operate through agents. }\end{array}$ \\
\hline 2. Accountability & n.a. Not applicable & $\begin{array}{l}2 \text { Financial institutions } \\
\text { retain full } \\
\text { responsibility for the } \\
\text { service offered via } \\
\text { correspondents. }\end{array}$ & $\begin{array}{l}2 \text { The agents' regulatory and } \\
\text { legal compliance remains } \\
\text { with the financial } \\
\text { institution, as well as } \\
\text { responsibility for risk } \\
\text { management }\end{array}$ & $\begin{array}{l}2 \text { Financial institutions } \\
\text { retain the sole } \\
\text { responsibility. }\end{array}$ & $\begin{array}{l}2 \text { Financial institutions } \\
\text { retain the sole } \\
\text { responsibility for the } \\
\text { service offered via } \\
\text { correspondents. }\end{array}$ & $\begin{array}{l}2 \text { Financial institutions } \\
\text { retain the sole } \\
\text { responsibility for the } \\
\text { service offered via } \\
\text { correspondents }\end{array}$ & $\begin{array}{l}2 \text { Financial institutions } \\
\text { retain the sole } \\
\text { responsibility for the } \\
\text { service offered via } \\
\text { correspondents }\end{array}$ & $\begin{array}{l}2 \text { Financial institutions } \\
\text { are responsible for the } \\
\text { services provided. }\end{array}$ \\
\hline 3. Business Models & n.a. Not applicable & 2 & 1.5 & 2 & 2 & 1.5 & 2 & 2 \\
\hline $\begin{array}{l}\text { 3A. Types of } \\
\text { establishments }\end{array}$ & -- & $\begin{array}{l}2 \text { Companies, } \\
\text { entrepreneurs, } \\
\text { business associations, } \\
\text { and financial } \\
\text { institutions can be } \\
\text { correspondents. }\end{array}$ & $\begin{array}{l}2 \text { Any establishment whose } \\
\text { legal regime allows it to } \\
\text { serve the public can serve } \\
\text { as a correspondent, } \\
\text { including financial } \\
\text { institutions of small size. }\end{array}$ & $\begin{array}{l}2 \text { Any natural or legal } \\
\text { person who attends the } \\
\text { public may act as } \\
\text { correspondent, } \\
\text { provided that its legal } \\
\text { regime or social object } \\
\text { allows it, including } \\
\text { financial institutions. }\end{array}$ & $\begin{array}{l}2 \text { Correspondents may } \\
\text { be legal entities or } \\
\text { individuals with a } \\
\text { business activity and a } \\
\text { permanent } \\
\text { establishment. }\end{array}$ & $\begin{array}{l}1 \text { Non-banking } \\
\text { correspondents are natural } \\
\text { or legal persons who work } \\
\text { in their own or third-party } \\
\text { establishments. Their } \\
\text { activity as correspondents } \\
\text { is complementary to its } \\
\text { main commercial activity. }\end{array}$ & $\begin{array}{l}2 \text { Points of service, either } \\
\text { fixed or mobile, } \\
\text { managed by an } \\
\text { operator, who is the } \\
\text { natural or legal person, } \\
\text { different from the } \\
\text { financial companies, } \\
\text { which operates } \\
\text { correspondent tellers. }\end{array}$ & $\begin{array}{l}2 \text { If not linked to a } \\
\text { correspondent } \\
\text { administrator, they can } \\
\text { be legal persons } \\
\text { governed by public law } \\
\text { and legal entities } \\
\text { constituted as } \\
\text { commercial companies, } \\
\text { cooperatives or civil } \\
\text { associations. }\end{array}$ \\
\hline $\begin{array}{l}\text { 3B. Management of the } \\
\text { network }\end{array}$ & - & $\begin{array}{l}2 \text { Institutions are } \\
\text { allowed to operate } \\
\text { through a network } \\
\text { administrator, but } \\
\text { retain the } \\
\text { responsibility of the } \\
\text { agents' actions in any } \\
\text { case. }\end{array}$ & $\begin{array}{l}1 \text { Regulation does not deal } \\
\text { with the issue of whether } \\
\text { the financial institution } \\
\text { can work directly and } \\
\text { indirectly with } \\
\text { correspondents. }\end{array}$ & $\begin{array}{l}2 \text { Institutions are allowed } \\
\text { to operate through a } \\
\text { network administrator, } \\
\text { but retain the } \\
\text { responsibility of the } \\
\text { agents' actions in any } \\
\text { case. }\end{array}$ & $\begin{array}{l}2 \text { Institutions can } \\
\text { operate through an } \\
\text { administrator, who } \\
\text { will hold joint liability } \\
\text { with the institution } \\
\text { for the activities of } \\
\text { the agents }\end{array}$ & $\begin{array}{l}2 \text { Institutions can operate } \\
\text { through an administrator. } \\
\text { Financial institutions } \\
\text { cannot transfer } \\
\text { responsibility for the } \\
\text { agents' actions to the } \\
\text { administrator. }\end{array}$ & $\begin{array}{l}2 \text { Institutions can work } \\
\text { directly and indirectly } \\
\text { (through an } \\
\text { administrator), but } \\
\text { retain the responsibility } \\
\text { of the agents' actions in } \\
\text { any case. }\end{array}$ & $\begin{array}{l}2 \text { Institutions can work } \\
\text { directly or through an } \\
\text { administrator, who is } \\
\text { responsible for the } \\
\text { adequate provision of } \\
\text { services. The } \\
\text { institution is the } \\
\text { ultimate responsible. }\end{array}$ \\
\hline 4. Permitted activities & n.a. Not applicable & 2 & 1 & 2 & 1.3 & 2 & 2 & 1.7 \\
\hline $\begin{array}{l}\text { 4A. Transactional } \\
\text { services }\end{array}$ & -- & $\begin{array}{l}2 \text { Payments and } \\
\text { electronic transfers, } \\
\text { cash deposits and } \\
\text { withdrawals from } \\
\text { bank accounts, } \\
\text { disbursements and } \\
\text { reimbursements of } \\
\text { credits. }\end{array}$ & $\begin{array}{l}2 \text { Regulation does not } \\
\text { provide an explicit list of } \\
\text { services to be offered } \\
\text { through correspondents, } \\
\text { but states that the } \\
\text { contract should address } \\
\text { this issue. }\end{array}$ & $\begin{array}{l}2 \text { Cash deposits and } \\
\text { withdrawals, transfers } \\
\text { of funds, balance } \\
\text { enquiries, } \\
\text { disbursements and } \\
\text { reimbursements of } \\
\text { credit, among others }\end{array}$ & $\begin{array}{l}2 \text { Among others: } \\
\text { transfers, deposits, } \\
\text { withdrawals from } \\
\text { bank accounts, } \\
\text { payments, payment of } \\
\text { credit, balance and } \\
\text { movement enquiries. }\end{array}$ & $\begin{array}{l}2 \text { Collect and disburse } \\
\text { credit, withdraw money, } \\
\text { consult balances and issue } \\
\text { extracts, transfer funds, } \\
\text { deposits in bank accounts, } \\
\text { payment of services and } \\
\text { collections in general. . }\end{array}$ & $\begin{array}{l}2 \text { Among others: } \\
\text { transfers, deposits, } \\
\text { withdrawals from bank } \\
\text { accounts, payments, } \\
\text { payment of credit, } \\
\text { balance and movement } \\
\text { enquiries }\end{array}$ & $\begin{array}{l}2 \text { Cash deposits and } \\
\text { withdrawals from bank } \\
\text { accounts, transfers, } \\
\text { disbursement and } \\
\text { reimbursement of } \\
\text { credit, balance } \\
\text { enquiries, payments. }\end{array}$ \\
\hline 4B. Credit & -- & $\begin{array}{l}2 \text { Collect and deliver } \\
\text { documentation and } \\
\text { information. }\end{array}$ & $\begin{array}{l}1 \text { Regulation does not } \\
\text { provide an explicit list of } \\
\text { products or services }\end{array}$ & $\begin{array}{l}2 \text { Collect and deliver } \\
\text { documentation and } \\
\text { information and } \\
\text { activate pre-approved } \\
\text { credit products }\end{array}$ & $\begin{array}{l}1 \text { Regulation does not } \\
\text { allow correspondents } \\
\text { to intervene in the } \\
\text { process of granting } \\
\text { credit }\end{array}$ & $\begin{array}{l}2 \text { Collect and deliver } \\
\text { proposals related to credit } \\
\text { applications. }\end{array}$ & $\begin{array}{l}2 \text { Receive applications } \\
\text { from natural persons } \\
\text { regarding credit }\end{array}$ & $\begin{array}{l}2 \text { Collect and deliver } \\
\text { documentation and } \\
\text { information. }\end{array}$ \\
\hline
\end{tabular}




\begin{tabular}{|c|c|c|c|c|c|c|c|c|}
\hline Criteria/ Country & Argentina & Brazil & Chile & Colombia & Mexico & Paraguay & Peru & Uruguay \\
\hline $\begin{array}{l}\text { 4C. Affiliation of new } \\
\text { clients }\end{array}$ & -- & $\begin{array}{l}2 \text { Collect and deliver } \\
\text { documentation for } \\
\text { standard accounts, } \\
\text { and complete } \\
\text { opening of simplified } \\
\text { accounts }\end{array}$ & $\begin{array}{l}0 \text { Regulation excludes the } \\
\text { opening of accounts from } \\
\text { the activities that can be } \\
\text { outsourced via } \\
\text { correspondents. }\end{array}$ & $\begin{array}{l}2 \text { Collect and deliver } \\
\text { documentation for } \\
\text { standard accounts, and } \\
\text { complete opening of } \\
\text { simplified accounts }\end{array}$ & $\begin{array}{l}2 \text { Correspondents can } \\
\text { perform the opening } \\
\text { of bank accounts of } \\
\text { levels } 1,2 \text { and } 3 .\end{array}$ & $\begin{array}{l}2 \text { Collect and deliver } \\
\text { documentation for } \\
\text { standard accounts, and } \\
\text { complete opening of } \\
\text { simplified accounts }\end{array}$ & $\begin{array}{l}2 \text { Collect and deliver } \\
\text { documentation for } \\
\text { standard accounts, and } \\
\text { complete opening of } \\
\text { simplified accounts. }\end{array}$ & $\begin{array}{l}1 \text { Collect and deliver } \\
\text { documentation for } \\
\text { bank accounts, even } \\
\text { simplified accounts, } \\
\text { which cannot be } \\
\text { opened by agents } \\
\end{array}$ \\
\hline 5. Transactional limits & n.a. Not applicable & $\begin{array}{l}1 \text { Regulation does not } \\
\text { deal with this issue. }\end{array}$ & $\begin{array}{l}2 \text { Regulation requires the } \\
\text { establishment to define } \\
\text { limits, but gives room to } \\
\text { set them. }\end{array}$ & $\begin{array}{l}2 \text { Regulation requires the } \\
\text { establishment to set } \\
\text { limits, but gives room } \\
\text { to set them. }\end{array}$ & $\begin{array}{l}1 \text { Regulation sets } \\
\text { transactional limits for } \\
\text { each account, but not } \\
\text { to the aggregate sum } \\
\text { of transactions }\end{array}$ & $\begin{array}{l}2 \text { Regulation requires the } \\
\text { establishment to define } \\
\text { limits, but gives room to } \\
\text { set them. }\end{array}$ & $\begin{array}{l}2 \text { Companies should } \\
\text { establish prudent limits } \\
\text { for the provision of } \\
\text { services related to the } \\
\text { operator's cash flow. }\end{array}$ & $\begin{array}{l}2 \text { Companies should } \\
\text { establish limits for the } \\
\text { provision of services }\end{array}$ \\
\hline 6. Operational requirements & n.a. Not applicable & 1 & 1 & 1.8 & 2 & 1.8 & 1 & 1.5 \\
\hline $\begin{array}{l}\text { 6A. Security of the } \\
\text { information }\end{array}$ & -- & $\begin{array}{l}2 \text { Confidentiality is } \\
\text { guaranteed through } \\
\text { accessible means }\end{array}$ & $\begin{array}{l}2 \text { Confidentiality is } \\
\text { guaranteed through } \\
\text { accessible means }\end{array}$ & $\begin{array}{l}2 \text { Confidentiality is } \\
\text { guaranteed through } \\
\text { accessible means }\end{array}$ & $\begin{array}{l}2 \text { Confidentiality is } \\
\text { guaranteed through } \\
\text { accessible means }\end{array}$ & $\begin{array}{l}2 \text { Confidentiality is } \\
\text { guaranteed through } \\
\text { accessible means }\end{array}$ & $\begin{array}{l}2 \text { Confidentiality is } \\
\text { guaranteed through } \\
\text { accessible means }\end{array}$ & $\begin{array}{l}2 \text { Confidentiality is } \\
\text { guaranteed through } \\
\text { accessible means }\end{array}$ \\
\hline $\begin{array}{l}\text { 6B. Training and capacity } \\
\text { building }\end{array}$ & -- & $\begin{array}{l}2 \text { Correspondents must } \\
\text { be externally certified } \\
\text { to be able to operate. }\end{array}$ & $\begin{array}{l}2 \text { Correspondents are } \\
\text { required to follow an } \\
\text { accessible capacity- } \\
\text { building process }\end{array}$ & $\begin{array}{l}2 \text { Correspondents are } \\
\text { required to follow an } \\
\text { accessible capacity- } \\
\text { building process. }\end{array}$ & $\begin{array}{l}2 \text { Correspondents must } \\
\text { follow an accessible } \\
\text { capacity building } \\
\text { process }\end{array}$ & $\begin{array}{l}2 \text { Correspondents are } \\
\text { required to follow an } \\
\text { accessible capacity- } \\
\text { building process }\end{array}$ & $\begin{array}{l}2 \text { Correspondents are } \\
\text { required to follow an } \\
\text { accessible capacity- } \\
\text { building process }\end{array}$ & $\begin{array}{l}2 \text { Correspondents are } \\
\text { required to follow an } \\
\text { accessible capacity- } \\
\text { building process }\end{array}$ \\
\hline $\begin{array}{l}\text { 6C. Records of } \\
\text { transactions }\end{array}$ & -- & $\begin{array}{l}0 \text { Regulation does not } \\
\text { deal with this issue }\end{array}$ & $\begin{array}{l}0 \text { Regulation does not deal } \\
\text { with this issue }\end{array}$ & $\begin{array}{l}2 \text { Records of transactions } \\
\text { can be delivered in } \\
\text { physical or electronic } \\
\text { format. }\end{array}$ & $\begin{array}{l}2 \text { All operations must } \\
\text { generate electronic } \\
\text { records. }\end{array}$ & $\begin{array}{l}2 \text { Records of transactions } \\
\text { can be delivered in } \\
\text { physical or electronic } \\
\text { format }\end{array}$ & $\begin{array}{l}0 \text { Regulation does not } \\
\text { deal with the need to } \\
\text { handle records of } \\
\text { transactions }\end{array}$ & $\begin{array}{l}0 \text { Regulation does not } \\
\text { deal with the need to } \\
\text { handle records of } \\
\text { transactions }\end{array}$ \\
\hline 6D. In-line operations & -- & $\begin{array}{l}0 \text { Regulation does not } \\
\text { require operations to } \\
\text { be performed online, } \\
\text { even transactions } \\
\text { with risk of fraud by } \\
\text { multiple withdrawal }\end{array}$ & $\begin{array}{l}0 \text { Regulation does not } \\
\text { require operations to be } \\
\text { performed online, even in } \\
\text { the case of transactions } \\
\text { with risk of fraud by } \\
\text { multiple withdrawals }\end{array}$ & $\begin{array}{l}1 \text { Operations must be } \\
\text { performed always } \\
\text { through electronic } \\
\text { means connected in- } \\
\text { line to the } \\
\text { technological platform } \\
\text { of the entity }\end{array}$ & $\begin{array}{l}2 \text { Institutions must } \\
\text { transfer resources } \\
\text { online, except for the } \\
\text { payment of credits in } \\
\text { favor of the } \\
\text { institution. }\end{array}$ & $\begin{array}{l}1 \text { Operations must be } \\
\text { performed always through } \\
\text { electronic means } \\
\text { connected to the } \\
\text { technological platform of } \\
\text { the entity. }\end{array}$ & $\begin{array}{l}0 \text { Regulation does not } \\
\text { require operations to } \\
\text { be online, even for } \\
\text { transactions with risk } \\
\text { of fraud by multiple } \\
\text { withdrawals }\end{array}$ & $\begin{array}{l}2 \text { Most operations must } \\
\text { be performed online, } \\
\text { except from payments } \\
\text { of services or credit. }\end{array}$ \\
\hline 7. Supervision & n.a. Not applicable & 1 & 1 & 2 & 1 & 2 & 2 & 1 \\
\hline 7A. Authorization & -- & $\begin{array}{l}0 \text { No authorization is } \\
\text { required to operate } \\
\text { the channel, just } \\
\text { upload individual } \\
\text { agent information } \\
\text { into an online system. } \\
\text { Until 2009, BCB had } \\
\text { to authorize each } \\
\text { correspondent, but } \\
\text { not any more }\end{array}$ & $\begin{array}{l}0 \text { Circular } 3570 \text { of } 2014 \\
\text { removed the previous } \\
\text { regulatory provision that } \\
\text { forced financial } \\
\text { institutions to request } \\
\text { authorization to the SBIF } \\
\text { prior to the outsourcing } \\
\text { of any service. }\end{array}$ & $\begin{array}{l}2 \text { Institutions need } \\
\text { authorization from the } \\
\text { SFC on the contract } \\
\text { model but individual } \\
\text { agent authorization is } \\
\text { not needed. }\end{array}$ & $\begin{array}{l}1 \text { It is a two-phased } \\
\text { process: (1) one-time } \\
\text { authorization for the } \\
\text { agent channel and (2) } \\
\text { one-time agent } \\
\text { certification through } \\
\text { onsite checks. This } \\
\text { process is seen as too } \\
\text { complex and time- } \\
\text { consuming }\end{array}$ & $\begin{array}{l}2 \text { Regulation requires } \\
\text { institutions to obtain } \\
\text { authorization for the use } \\
\text { of correspondents prior to } \\
\text { start using this channel, } \\
\text { but not on a case-by-case } \\
\text { basis. }\end{array}$ & $\begin{array}{l}2 \text { Financial institutions } \\
\text { only need a one-time } \\
\text { authorization to start } \\
\text { operating the agents' } \\
\text { channels. Individual } \\
\text { authorizations to } \\
\text { operate through each } \\
\text { agent are not } \\
\text { requested. }\end{array}$ & $\begin{array}{l}0 \text { Institutions must obtain } \\
\text { authorization from the } \\
\text { SSF to operate with } \\
\text { each agent. Information } \\
\text { requested includes: } \\
\text { agent identification } \\
\text { details, services } \\
\text { contracted, contract } \\
\text { and remuneration } \\
\text { mechanism }\end{array}$ \\
\hline 7B. On-going supervision & -- & $\begin{array}{l}2 \mathrm{BCB} \text { has the right to } \\
\text { access all the } \\
\text { documentation on } \\
\text { products and services } \\
\text { offered via } \\
\text { correspondents, and } \\
\text { access to their } \\
\text { premises. }\end{array}$ & $\begin{array}{l}2 \text { The SBIF has access } \\
\text { through direct visits or } \\
\text { through records and } \\
\text { information. All } \\
\text { procedures should be } \\
\text { properly documented, } \\
\text { updated and permanently } \\
\text { available for the SBIF. }\end{array}$ & $\begin{array}{l}2 \text { The regulator has the } \\
\text { power to carry out } \\
\text { visits to the } \\
\text { correspondents and to } \\
\text { request reasonable } \\
\text { information consistent } \\
\text { with the model. }\end{array}$ & $\begin{array}{l}1 \text { Institutions may } \\
\text { receive home visits by } \\
\text { the CNBV and must } \\
\text { elaborate and } \\
\text { periodically update a } \\
\text { business plan. This } \\
\text { requirement has been } \\
\text { identified as too } \\
\text { onerous. }\end{array}$ & $\begin{array}{l}2 \text { Correspondents may } \\
\text { receive visits from the } \\
\text { Superintendence and be } \\
\text { available to supervision } \\
\text { and control actions. In } \\
\text { addition they must present } \\
\text { necessary manuals, } \\
\text { minutes and reports }\end{array}$ & $\begin{array}{l}2 \text { There is no } \\
\text { impediment for the } \\
\text { supervisor to conduct } \\
\text { on-site inspections. } \\
\text { Banks must report the } \\
\text { number, identity and } \\
\text { location of } \\
\text { correspondents } \\
\text { quarterly }\end{array}$ & $\begin{array}{l}2 \text { The SSF must have } \\
\text { access to all the data } \\
\text { and documentation } \\
\text { needed for the control } \\
\text { procedures. }\end{array}$ \\
\hline
\end{tabular}




\begin{tabular}{|c|c|c|c|c|c|c|c|c|}
\hline Criteria/ Country & Argentina & Brazil & Chile & Colombia & Mexico & Paraguay & Peru & Uruguay \\
\hline $\begin{array}{l}\text { 8. Interoperability and } \\
\text { exclusivity }\end{array}$ & n.a. Not applicable & $\begin{array}{l}1 \text { Regulation does not } \\
\text { deal with the issue of } \\
\text { exclusivity, although } \\
\text { in practice there are } \\
\text { exclusivity } \\
\text { arrangements (CGAP, } \\
\text { 2011) }\end{array}$ & $\begin{array}{l}1 \text { Regulation does not deal } \\
\text { with the issue of } \\
\text { exclusivity }\end{array}$ & $\begin{array}{l}2 \text { Exclusivity is not } \\
\text { mandated. When } \\
\text { working with several } \\
\text { financial institutions, } \\
\text { correspondents must } \\
\text { refrain from } \\
\text { performing acts of } \\
\text { discrimination or } \\
\text { preference bet ween } \\
\text { them. In practice, } \\
\text { there are exclusivity } \\
\text { arrangements. }\end{array}$ & $\begin{array}{l}2 \text { Exclusivity is } \\
\text { explicitly permitted by } \\
\text { the regulation, } \\
\text { although it is not } \\
\text { mandated. When } \\
\text { correspondents do } \\
\text { enter into exclusivity } \\
\text { agreements, they } \\
\text { cannot work with } \\
\text { other banks for one } \\
\text { year. }\end{array}$ & $\begin{array}{l}2 \text { Exclusivity is not } \\
\text { mandated nor prohibited. } \\
\text { When working with } \\
\text { several financial } \\
\text { institutions, } \\
\text { correspondents must } \\
\text { refrain from performing } \\
\text { acts of discrimination or } \\
\text { preference between them. } \\
\text { In practice, a financial } \\
\text { institution may } \\
\text { contractually require } \\
\text { exclusivity }\end{array}$ & $\begin{array}{l}2 \text { Operators and } \\
\text { aggregators of } \\
\text { correspondents may } \\
\text { operate with several } \\
\text { companies, therefore } \\
\text { exclusivity is not } \\
\text { mandated. According } \\
\text { to CAF (2013), } \\
\text { exclusivity used to be } \\
\text { prohibited in the past, } \\
\text { although this is not } \\
\text { case now }\end{array}$ & $\begin{array}{l}0 \text { The regulation } \\
\text { explicitly prohibits } \\
\text { financial institutions } \\
\text { signing exclusivity } \\
\text { arrangements with } \\
\text { correspondents. }\end{array}$ \\
\hline 9. Fees and commissions & n.a. Not applicable & 0 & 0.8 & 2 & 2 & 2 & 2 & 2 \\
\hline $\begin{array}{l}\text { 9A. Agents' fees and } \\
\text { commissions }\end{array}$ & -- & $\begin{array}{l}0 \text { The regulation } \\
\text { establishes strict } \\
\text { limits on the } \\
\text { remuneration paid to } \\
\text { the correspondent. }\end{array}$ & $\begin{array}{l}2 \text { The contract with the } \\
\text { external provider must } \\
\text { include the scheme of } \\
\text { fees and commissions for } \\
\text { the activities outsourced. }\end{array}$ & $\begin{array}{l}2 \text { There are no } \\
\text { restrictions on the fees } \\
\text { and commissions set } \\
\text { by the financial } \\
\text { institution, but these } \\
\text { must be specified in the } \\
\text { contract. }\end{array}$ & $\begin{array}{l}2 \text { The regulation does } \\
\text { not restrict the } \\
\text { commissions to be } \\
\text { paid by the institution } \\
\text { to the correspondent. }\end{array}$ & $\begin{array}{l}2 \text { Contracts with } \\
\text { correspondents should } \\
\text { include commissions to be } \\
\text { paid to them. }\end{array}$ & $\begin{array}{l}2 \text { There are no } \\
\text { restrictions on the fees } \\
\text { set by the financial } \\
\text { institution }\end{array}$ & $\begin{array}{l}2 \text { There are no } \\
\text { restrictions on the fees } \\
\text { set by the financial } \\
\text { institution }\end{array}$ \\
\hline $\begin{array}{l}\text { 9B. Clients' fees and } \\
\text { commissions }\end{array}$ & - & $\begin{array}{l}0 \text { Institutions are not } \\
\text { allowed to charge } \\
\text { fees to the client for } \\
\text { the services offered } \\
\text { via correspondents. } \\
\text { The correspondent } \\
\text { must stick to the } \\
\text { scheme of fees and } \\
\text { commissions set by } \\
\text { the institution, and } \\
\text { cannot charge other } \\
\text { fees }\end{array}$ & $\begin{array}{l}0 \text { The regulation does not } \\
\text { explicitly impede the } \\
\text { external provider to } \\
\text { charge additional fees and } \\
\text { commissions to the } \\
\text { institutions' clients. }\end{array}$ & $\begin{array}{l}2 \text { There are no } \\
\text { restrictions on the fees } \\
\text { and commissions, but } \\
\text { these must be specified } \\
\text { in the contract. The } \\
\text { correspondent cannot } \\
\text { by itself charge } \\
\text { additional fees to the } \\
\text { client. }\end{array}$ & $\begin{array}{l}2 \text { Correspondents } \\
\text { cannot charge } \\
\text { commissions to } \\
\text { clients, or receive } \\
\text { price differentials. } \\
\text { Furthermore, the } \\
\text { regulation does not } \\
\text { restrict the } \\
\text { commissions to be } \\
\text { charged by the } \\
\text { institution to the } \\
\text { client. }\end{array}$ & $\begin{array}{l}2 \text { Correspondents are not } \\
\text { allowed to charge fees or } \\
\text { commissions for the } \\
\text { provision of services to } \\
\text { final customers. } \\
\text { Furthermore, the } \\
\text { regulation does not restrict } \\
\text { the commissions to be } \\
\text { charged by the institution } \\
\text { to the client }\end{array}$ & $\begin{array}{l}2 \text { There are no } \\
\text { restrictions on the fees } \\
\text { and commissions set } \\
\text { by the financial } \\
\text { institution and the } \\
\text { correspondent cannot } \\
\text { by itself charge } \\
\text { additional fees and } \\
\text { commissions to the } \\
\text { client. }\end{array}$ & $\begin{array}{l}2 \text { There are no } \\
\text { restrictions on the fees } \\
\text { and commissions set by } \\
\text { the financial institution } \\
\text { and the correspondent } \\
\text { cannot by itself charge } \\
\text { additional fees and } \\
\text { commissions to the } \\
\text { client. }\end{array}$ \\
\hline $\begin{array}{l}\text { 9B.a. Adjusted Clients' } \\
\text { fees and commission for } \\
\text { quality of competition } \\
\text { policies }\end{array}$ & -- & 0 & 0 & 2 & 2 & 2 & 2 & 2 \\
\hline $\begin{array}{l}\text { Correspondents Sub-Index } \\
\text { Score }\end{array}$ & 0 & 1.3 & 1.3 & 1.97 & 1.7 & 1.8 & 1.9 & 1.6 \\
\hline
\end{tabular}




\section{Annex XI: Microcredit: Summary of Regulatory Findings}

\begin{tabular}{|c|c|c|c|c|c|c|c|c|}
\hline Criteria/ Country & Argentina & Brazil & Chile & Colombia & Mexico & Paraguay & Peru & Uruguay \\
\hline 1. Regulatory framework & 1 & 2 & 1 & 2 & 1 & 1 & 2 & 1 \\
\hline $\begin{array}{l}\text { 1A. Regulatory definition } \\
\text { and dedicated framework }\end{array}$ & $\begin{array}{l}2 \text { Microcredit is defined } \\
\text { by Law as any loan } \\
\text { financing an individual } \\
\text { or household that does } \\
\text { not exceed } 12 \text { minimum } \\
\text { wages, and provided by } \\
\text { non-for profit } \\
\text { institutions. This } \\
\text { differentiates } \\
\text { productive microcredit } \\
\text { from consumption } \\
\text { lending. }\end{array}$ & $\begin{array}{l}2 \text { BCB rules define } \\
\text { microcredit as an } \\
\text { operation with a } \\
\text { natural or legal person } \\
\text { which uses a specific } \\
\text { lending methodology } \\
\text { and has a volume } \\
\text { below } 3 \text { times GDP } \\
\text { per capita. This } \\
\text { differentiates } \\
\text { productive microcredit } \\
\text { from consumption } \\
\text { lending. }\end{array}$ & $\begin{array}{l}0 \text { There is no formal } \\
\text { definition or specific } \\
\text { regulatory framework for } \\
\text { microcredit in Chile. } \\
\text { There is also no formal } \\
\text { legal figure for } \\
\text { microfinance institutions. } \\
\text { This is creating } \\
\text { insufficient competition } \\
\text { in the market, dominated } \\
\text { by banks, and specially, } \\
\text { the public bank } \\
\text { BancoEstado. }\end{array}$ & $\begin{array}{l}2 \text { Microcredit was } \\
\text { formally defined in } \\
2000 \text {. Subsequent } \\
\text { amendments to the } \\
\text { regulatory framework } \\
\text { have raised the } \\
\text { balance limit of } \\
\text { microcredit, as well as } \\
\text { made additional } \\
\text { efforts to } \\
\text { differentiate } \\
\text { productive } \\
\text { microcredit from } \\
\text { consumption lending. }\end{array}$ & $\begin{array}{l}2 \text { There is no separate } \\
\text { regulatory framework, } \\
\text { but a definition has } \\
\text { been incorporated in } \\
\text { the regulations of } \\
\text { banks in } 2017 \text {, and } \\
\text { already existed in the } \\
\text { regulations of socaps } \\
\text { and sofipos. These } \\
\text { definitions } \\
\text { differentiate } \\
\text { productive } \\
\text { microcredit from } \\
\text { consumption lending. }\end{array}$ & $\begin{array}{l}2 \text { Microcredit is formally } \\
\text { defined as a loan to } \\
\text { support small-scale } \\
\text { production, sales or } \\
\text { service activities of natural } \\
\text { or legal persons in } \\
\text { amounts below } 25 \text { times } \\
\text { the monthly minimum } \\
\text { wage. This differentiates } \\
\text { productive microcredit } \\
\text { from consumption } \\
\text { lending. }\end{array}$ & $\begin{array}{l}2 \text { Microcredit is defined } \\
\text { under the General Law } \\
\text { on the Financial } \\
\text { System, which also } \\
\text { defines Development } \\
\text { Entity for Small and } \\
\text { Medium Enterprises } \\
\text { (EDPYME), as credits } \\
\text { to finance production, } \\
\text { commercialization or } \\
\text { provision of services to } \\
\text { natural or legal } \\
\text { persons. }\end{array}$ & $\begin{array}{l}0 \text { Uruguay has no } \\
\text { specific regulatory } \\
\text { framework for } \\
\text { microcredit, and this } \\
\text { modality of loans is } \\
\text { not contemplated in } \\
\text { national legislation }\end{array}$ \\
\hline 1B. Functional approach & $\begin{array}{l}0 \text { The Law on microcredit } \\
\text { regulates the activity of } \\
\text { non-for profit } \\
\text { microcredit institutions, } \\
\text { but not of regulated } \\
\text { ones. Microcredit } \\
\text { offered by these } \\
\text { institutions is not } \\
\text { defined nor regulated } \\
\text { differently to any other } \\
\text { type of credit. }\end{array}$ & $\begin{array}{l}2 \text { Regulatory definition } \\
\text { of microcredit is based } \\
\text { on the methodology } \\
\text { for granting the loans } \\
\text { and the volume, } \\
\text { regardless of the source } \\
\text { of the funds provided. } \\
\text { Regulation for } \\
\text { microcredit applies } \\
\text { equally to all } \\
\text { institutions offering it }\end{array}$ & $\begin{array}{l}2 \text { Since there is no formal } \\
\text { definition or specific } \\
\text { regulatory framework for } \\
\text { microcredit, existing } \\
\text { supervision standards and } \\
\text { regulation are of a general } \\
\text { nature and apply to the } \\
\text { financial system in whole. }\end{array}$ & $\begin{array}{l}2 \text { There is no micro } \\
\text { finance specific } \\
\text { vehicle, but regulated } \\
\text { financial institutions } \\
\text { and NGOs are } \\
\text { allowed to offer it. } \\
\text { Rules are based on } \\
\text { the size of the loan } \\
\text { and the type of client, } \\
\text { and not on the } \\
\text { institution offering it. }\end{array}$ & $\begin{array}{l}0 \text { Lack of specific } \\
\text { definition and } \\
\text { regulation on } \\
\text { microcredit has lead } \\
\text { different types of } \\
\text { institutions to use } \\
\text { different operational } \\
\text { definitions of } \\
\text { microcredit in } \\
\text { practice. }\end{array}$ & $\begin{array}{l}0 \text { Rules on microcredit only } \\
\text { apply to banks and } \\
\text { financing companies. } \\
\text { Under the regulatory } \\
\text { framework for credit } \\
\text { cooperatives, microcredit } \\
\text { is not defined nor } \\
\text { differentiated from any } \\
\text { other type of credit. } \\
\text { Regulation is based on the } \\
\text { provider rather than on } \\
\text { the financial product }\end{array}$ & $\begin{array}{l}2 \text { Rules on microcredit } \\
\text { apply to banks and all } \\
\text { other financial } \\
\text { institutions that are } \\
\text { regulated by the SBS. } \\
\text { Differences in } \\
\text { regulatory provisions } \\
\text { are based on the } \\
\text { activities and not on } \\
\text { the type of institution. }\end{array}$ & $\begin{array}{l}2 \text { Since there is no } \\
\text { formal definition or } \\
\text { specific regulatory } \\
\text { framework for } \\
\text { microcredit, existing } \\
\text { supervision standards } \\
\text { and regulation are of a } \\
\text { general nature and } \\
\text { apply to the financial } \\
\text { system in whole. }\end{array}$ \\
\hline 2. Prudential regulation & 1 & 0.5 & 0 & 1 & 1 & 1.5 & 2 & 0 \\
\hline $\begin{array}{l}\text { 2A. Regulatory } \\
\text { framework for risk } \\
\text { management }\end{array}$ & $\begin{array}{l}0 \text { There is no a } \\
\text { differentiated risk } \\
\text { management } \\
\text { framework. Microcredit } \\
\text { granted by regulated } \\
\text { institutions are } \\
\text { classified, provisioned } \\
\text { and managed following } \\
\text { the general rules that } \\
\text { apply to all types of } \\
\text { credit, without any } \\
\text { consideration to the } \\
\text { idiosyncrasies of } \\
\text { microcredit. }\end{array}$ & $\begin{array}{l}1 \text { The Brazilian model of } \\
\text { microcredit is based on } \\
\text { the methodology used } \\
\text { for the relationship } \\
\text { with the client, which is } \\
\text { based on direct } \\
\text { contacts and visits of a } \\
\text { microcredit agent from } \\
\text { the offering institution. } \\
\text { No collateral is } \\
\text { required for this type } \\
\text { of loans. There is no } \\
\text { specific provisioning } \\
\text { regime }\end{array}$ & $\begin{array}{l}0 \text { Since there is no formal } \\
\text { definition for microcredit, } \\
\text { there is also no } \\
\text { differentiated risk } \\
\text { management framework } \\
\text { for microcredit portfolios } \\
\text { of banks and regulated } \\
\text { institutions. The } \\
\text { provisioning regime for } \\
\text { microcredit portfolios is } \\
\text { the same as for the } \\
\text { consumer credit collective } \\
\text { portfflios. }\end{array}$ & $\begin{array}{l}2 \text { Since } 2008, \\
\text { microcredit has been } \\
\text { recognized as a } \\
\text { different loan } \\
\text { category in terms of } \\
\text { provisioning and loan } \\
\text { classification. The } \\
\text { microcredit portfolio } \\
\text { might have different } \\
\text { provisioning } \\
\text { requirements } \\
\text { depending on factors } \\
\text { like the quality of the } \\
\text { loans. }\end{array}$ & $\begin{array}{l}2 \text { The amendment } \\
\text { introduced in } 2017 \text { to } \\
\text { the regulations for } \\
\text { credit institutions } \\
\text { includes a } \\
\text { differentiated risk } \\
\text { management } \\
\text { framework for } \\
\text { microcredit portfolios, } \\
\text { as regards loan } \\
\text { classification, } \\
\text { provisioning and } \\
\text { collateral required. }\end{array}$ & $\begin{array}{l}1 \text { There is a dedicated risk } \\
\text { management framework } \\
\text { for banks and financing } \\
\text { companies, but it could be } \\
\text { improved as regards } \\
\text { provisioning and credit } \\
\text { risk assessment, which has } \\
\text { led to a permissive } \\
\text { treatment of these loans. } \\
\text { There is no differentiated } \\
\text { framework for } \\
\text { cooperatives. }\end{array}$ & $\begin{array}{l}2 \text { There is a dedicated } \\
\text { risk management } \\
\text { framework for } \\
\text { microcredit, and it is } \\
\text { comprehensive. } \\
\text { Main regulatory } \\
\text { requirements are not } \\
\text { based on the type of } \\
\text { institution. Loan loss } \\
\text { provisions depend on } \\
\text { the status of the loan, } \\
\text { rather than of the } \\
\text { institution offering it }\end{array}$ & $\begin{array}{l}0 \text { For regulated } \\
\text { institutions, there is } \\
\text { no specific risk } \\
\text { management } \\
\text { framework. In fact, } \\
\text { the President of the } \\
\text { BROU has stated that } \\
\text { this lack of regulation } \\
\text { is the main hurdle for } \\
\text { the development of } \\
\text { the microfinance } \\
\text { sector. }\end{array}$ \\
\hline
\end{tabular}


2B. Loan

2 The BCRA issued in

$0 \mathrm{BCB}$ rules do not

0 There are no simplified

0 Regulation does not

0 The amendment

introduced in 2017 to

2 Documentation

specify the
procedures for

allow the opening of

procedures for

is left to the

requirements for

microcredit. It has

minimum

micro entrepreneurs

requirements. The

consider loan

destination of the

consumption or for

documentation

productive activity.

requirements a major

ssing cred

rules do allow

simplified

ation for

the regulations for

equirements for granting

2 In the case of credit

institutions are

borrower's national

differentiated risk

management

identification document

institutions are
exempt of fulfilling

some of the

application and

microcredit portfolio,

conditions for the loan.

documentary

requirements, being

able to develop

consumption credit. differentiated loa

documentation

requirements.

3. Microcredit supervision $\quad 1.5$

3A. Institutional

microctit
1

1.5

BCB supervises all institutions that offer and are authorized to ake deposits, as well as take deposits, as well these are not deposit-

taking. Finally, non-fo profit organizations that offer microcredi are not supervised. According to EIU (2013), the BCB lacks specialized procedures and staff for microfinance. There are no specific supervisory tools for microcredit.

1.5

According to EIU (2013), there are no regulations specific to microfinance, nor is focused on this industry. There is no supervision of non-governmental organizations (NGOs) and Sociedades Anónimas, which compose a large part of the market, although these are not authorized to take deposits from the public.

\section{5}

According to $\mathrm{F}$ (2013), the SFC is the main supervisory body of depositaking microlenders. The majority of NGO MFIs do not fall under any supervisory body. The SFC lacks a microfinance specific supervisory tools for microcredit are contained under SFC's supervision rules.

1.5

All deposit-taking institutions are unde

supervisionAccording to EIU (2013), there microfinance department at the CNBV and no specific supervisory tools for microcredit are contained under the CNBV's supervision rules.

\section{3}

1.8

\section{Banks, finance}

\section{companies and}

deposits from the publi

and are supervised by the

BCP or the INCOOP.

According to EIU

(2013), the BCP has

small group of staff with

specialized knowledge of

the industry. No specific supervisory tools for microcredit are contained under the Central Bank's supervision rules.

\section{8}

1.5 Disin

tinct types of regulated institution
that can be involved in microcredit and are supervised by the also offered by nonregulated NGOs, which are not

supervised but cannot take deposits from the public. According to EIU (2013), the Supervisor has a welldepartment, but no specific supervisory tools.

$\begin{array}{lll}\text { 3B. Supervision } & \text { The supervisor is } \\ \text { procedures for } & \text { granted powers to } \\ \text { microcredit } & \text { conduct in situ and } \\ & \text { remote supervision } \\ \text { under the BCRA's } & \text { supervision rules. } \\ & \text { Remote supervision is } \\ \text { conducted through } \\ \text { reporting requirements } \\ \text { that according to EIU } \\ \text { (2016) are } \\ \text { differentiated } \\ \text { depending on the } \\ \text { institution. }\end{array}$

\begin{tabular}{|c|c|c|}
\hline $\begin{array}{l}\text { The supervisor is } \\
\text { granted powers to } \\
\text { conduct in situ and } \\
\text { remote supervision } \\
\text { under the Central } \\
\text { Bank's supervision } \\
\text { rules. Remote } \\
\text { supervision is } \\
\text { conducted through } \\
\text { reporting requirements } \\
\text { that according to EIU } \\
\text { (2016) are reasonable } \\
\text { for banks but not } \\
\text { tailored to other } \\
\text { companies such as } \\
\text { microenterprise credit } \\
\text { societies and non-bank } \\
\text { financial institutions }\end{array}$ & 2 & $\begin{array}{l}\text { The supervisor is } \\
\text { granted powers to } \\
\text { conduct in situ and } \\
\text { remote supervision } \\
\text { under SBIF's } \\
\text { supervision rules. } \\
\text { Remote supervision is } \\
\text { conducted through } \\
\text { reporting requirements } \\
\text { that according to EIU } \\
\text { (2016) differ depending } \\
\text { on the type of financial } \\
\text { institution. }\end{array}$ \\
\hline
\end{tabular}




\begin{tabular}{|c|c|c|c|c|c|c|c|c|}
\hline Criteria/ Country & Argentina & Brazil & Chile & Colombia & Mexico & Paraguay & Peru & Uruguay \\
\hline $\begin{array}{l}\text { 4. Non-prudential } \\
\text { regulation }\end{array}$ & 0.8 & 1.3 & 1.8 & 2 & 1.5 & 0.3 & 2 & 1.3 \\
\hline $\begin{array}{l}\text { 4A. Consumer } \\
\text { protection }\end{array}$ & $\begin{array}{l}1 \text { There is a general law } \\
\text { on consumer } \\
\text { protection and BCRA } \\
\text { rules on financial } \\
\text { consumer protection } \\
\text { that prohibit abusive } \\
\text { behavior towards } \\
\text { clients. BCRA has a } \\
\text { mandate to resolve } \\
\text { disputes regarding } \\
\text { banks and regulated } \\
\text { credit co-operatives, } \\
\text { NGOs, and private } \\
\text { companies owned by a } \\
\text { bank. There is also a } \\
\text { National Consumer } \\
\text { Protection Agency. }\end{array}$ & $\begin{array}{l}2 \text { All regulated financial } \\
\text { institutions are } \\
\text { required to have } \\
\text { financial ombudsmen } \\
\text { to handle complaints } \\
\text { from clients. The Law } \\
\text { on Consumer } \\
\text { Protection sets the } \\
\text { rules on abusive } \\
\text { collection and sales } \\
\text { practices. This Law is } \\
\text { enforced by the } \\
\text { National System for } \\
\text { Consumer Protection } \\
\text { which in } 2014 \text { created } \\
\text { an additional dispute- } \\
\text { settlement mechanism } \\
\text { under the online } \\
\text { platform } \\
\text { "consumidor.gov.br", } \\
\text { where consumers can } \\
\text { file complaints. }\end{array}$ & $\begin{array}{l}2 \text { All providers of credit } \\
\text { regulated or not, are } \\
\text { subject to the consumer } \\
\text { protection framework. } \\
\text { Relevant laws forbid } \\
\text { aggressive sales practices } \\
\text { and abusive behaviors } \\
\text { towards consumers. The } \\
\text { National Agency for } \\
\text { Consumer Protection } \\
\text { (SERNAC) has a } \\
\text { mechanism for dispute- } \\
\text { settlement. } \\
\text { Furthermore, } \\
\text { complaints in relation to } \\
\text { institutions regulated by } \\
\text { SBIF can be escalated to } \\
\text { this institution. }\end{array}$ & $\begin{array}{l}2 \text { Law } 1328 \text { of } 2009 \\
\text { created the financial } \\
\text { consumer protection } \\
\text { framework and a } \\
\text { Financial } \\
\text { Ombudsman within } \\
\text { the SFC to settle } \\
\text { disputes. } \\
\text { Cooperatives } \\
\text { regulated by SES and } \\
\text { unregulated } \\
\text { institutions are } \\
\text { subject to a Law that } \\
\text { imposes disclosure } \\
\text { requirements on all } \\
\text { credit providers. } \\
\text { Both laws prohibit } \\
\text { aggressive sales and } \\
\text { collection practices. }\end{array}$ & $\begin{array}{l}1 \text { Condusef is the } \\
\text { financial consumer } \\
\text { protection agency, } \\
\text { with powers on } \\
\text { regulated and non- } \\
\text { regulated lenders. It } \\
\text { offers a mechanism } \\
\text { to solve disputes and } \\
\text { its judgement can be } \\
\text { used in judicial } \\
\text { processes Since the } \\
2014 \text { Financial } \\
\text { Reform it has more } \\
\text { powers to deal with } \\
\text { abusive clauses. } \\
\text { Although it regulated } \\
\text { the activities of } \\
\text { Despacbos de Cobranza, } \\
\text { there is still evidence } \\
\text { of abusive collection } \\
\text { practices. }\end{array}$ & $\begin{array}{l}0 \text { The Law on Consumer } \\
\text { Protection regulates } \\
\text { consumer protection, } \\
\text { including for the } \\
\text { financial sector, and both } \\
\text { BCP and INCOOP have } \\
\text { issued additional rules. } \\
\text { However, these are not } \\
\text { uniform for banks and } \\
\text { cooperatives. There is } \\
\text { evidence of abusive } \\
\text { collection practices for } \\
\text { loans that are past due in } \\
\text { the case of non-regulated } \\
\text { institutions. These } \\
\text { institutions are not } \\
\text { subject to the same rules } \\
\text { on consumer protection } \\
\text { that apply to banks and } \\
\text { financing companies. }\end{array}$ & $\begin{array}{l}2 \text { The legal framework } \\
\text { for consumer } \\
\text { protection applies to } \\
\text { regulated and non- } \\
\text { regulated institutions. } \\
\text { It explicitly prohibits } \\
\text { aggressive sales and } \\
\text { collection practices. } \\
\text { Regulated institutions } \\
\text { must have a } \\
\text { mechanism to deal } \\
\text { with consumer } \\
\text { complaints. SBS does } \\
\text { not deal with } \\
\text { individual complaints } \\
\text { directly, but instead } \\
\text { forwards them to } \\
\text { INDECOPI, which } \\
\text { oversees and can } \\
\text { impose sanctions. }\end{array}$ & $\begin{array}{l}2 \text { The Consumer } \\
\text { Protection Law } \\
\text { established a mechanism } \\
\text { for dispute resolution } \\
\text { that applies to all } \\
\text { sectors, thereby covering } \\
\text { both regulated and non- } \\
\text { regulated MFIs. In the } \\
\text { case of financial services, } \\
\text { complaints can also be } \\
\text { addressed at the Central } \\
\text { Bank or to Auditoria } \\
\text { Interna de la Nacion (when } \\
\text { the institution involved } \\
\text { is a cooperative). }\end{array}$ \\
\hline $\begin{array}{l}\text { 4B. Disclosure and } \\
\text { transparency }\end{array}$ & $\begin{array}{l}0.5 \text { Non-regulated } \\
\text { institutions do not } \\
\text { have the legal } \\
\text { obligation to publish } \\
\text { their interest rates } \\
\text { according to } \\
\text { transparent and } \\
\text { consistent standards. } \\
\text { Regulated institutions } \\
\text { have to publish their } \\
\text { rules on financial } \\
\text { products, and the } \\
\text { BCRA collects pricing } \\
\text { and other relevant } \\
\text { market information } \\
\text { and publishes it on its } \\
\text { website. It allows } \\
\text { consumers to navigate } \\
\text { through different } \\
\text { products and gives a } \\
\text { list of financial } \\
\text { institutions that offer } \\
\text { them. }\end{array}$ & $\begin{array}{l}0.5 \text { Regulated financial } \\
\text { institutions must } \\
\text { disclose the total } \\
\text { effective cost (interest } \\
\text { rates and fees) in a } \\
\text { standardized form for } \\
\text { the products they } \\
\text { offer. Information is } \\
\text { published on a } \\
\text { monthly basis by the } \\
\text { Central Bank, broken } \\
\text { down into interest } \\
\text { rates, fees and } \\
\text { commissions. Non- } \\
\text { regulated providers are } \\
\text { not subject to any } \\
\text { disclosure } \\
\text { requirements. }\end{array}$ & $\begin{array}{l}\text { 1.5 There are disclosure } \\
\text { rules for all providers of } \\
\text { financial products and } \\
\text { these require transparent } \\
\text { pricing, clear contracts, } \\
\text { and full disclosure of } \\
\text { rights and obligations. } \\
\text { SBIF collects and } \\
\text { publishes on its website } \\
\text { information on pricing } \\
\text { of loans offered by } \\
\text { regulated institutions. } \\
\text { This information is not } \\
\text { presented in a way that } \\
\text { is easy to understand } \\
\text { and for comparisons } \\
\text { across entities. Lack of } \\
\text { transparency has been } \\
\text { identified as one of the } \\
\text { obstacles for the } \\
\text { development of the } \\
\text { market in Chile }\end{array}$ & $\begin{array}{l}2 \text { There are rules on } \\
\text { transparency and } \\
\text { disclosure } \\
\text { requirements for } \\
\text { SFC regulated } \\
\text { institutions, as well } \\
\text { as for cooperatives } \\
\text { regulated by the SES } \\
\text { and unregulated } \\
\text { institutions. SFC } \\
\text { collects monthly data } \\
\text { on fees, rates and } \\
\text { commissions, } \\
\text { including for } \\
\text { microloans, and } \\
\text { publishes it on its } \\
\text { website. Since 2010, } \\
\text { the price of products } \\
\text { offered by regulated } \\
\text { institutions is } \\
\text { published in national } \\
\text { newspapers on a } \\
\text { quarterly basis. }\end{array}$ & $\begin{array}{l}2 \text { Regulated and non- } \\
\text { regulated institutions } \\
\text { are required to } \\
\text { publish interest rates } \\
\text { using the Costo Anual } \\
\text { Total, including fees } \\
\text { and, commissions, } \\
\text { which Condusef } \\
\text { reports on its } \\
\text { website, and } \\
\text { institutions must } \\
\text { disclose in branches. } \\
\text { Since e } 016 \text {, Condusef } \\
\text { offers a comparator } \\
\text { of costs and interests. } \\
\text { The Credit Bureau } \\
\text { displays information } \\
\text { on all products } \\
\text { offered by regulated } \\
\text { and not regulated } \\
\text { institutions }\end{array}$ & $\begin{array}{l}0.5 \text { Central Bank rules on } \\
\text { transparency and } \\
\text { information disclosure } \\
\text { establish a methodology } \\
\text { to calculate and disclose } \\
\text { interest rates, fees and } \\
\text { commissions. Non- } \\
\text { regulated MFIs and } \\
\text { NGOs are not subject to } \\
\text { these rules } \\
\text { Information on interest } \\
\text { rates charged by } \\
\text { regulated institutions is } \\
\text { published in newspapers } \\
\text { and available at sight in } \\
\text { bank branches. }\end{array}$ & $\begin{array}{l}2 \text { Both regulated and } \\
\text { non-regulated } \\
\text { financial institutions } \\
\text { must disclose } \\
\text { effective interest rates, } \\
\text { expenses and other } \\
\text { fees, according to the } \\
\text { Code of Protection } \\
\text { and Defense of the } \\
\text { Consumers. } \\
\text { Information on } \\
\text { prices, fees and } \\
\text { commissions is } \\
\text { published online by } \\
\text { the SBS, as well as in } \\
\text { local newspapers } \\
\text { regularly. This allows } \\
\text { consumers to } \\
\text { compare information } \\
\text { by type of product } \\
\text { across all providers in } \\
\text { the consumer's } \\
\text { location. }\end{array}$ & $\begin{array}{l}0.5 \text { Regulated institutions } \\
\text { are required to provide } \\
\text { clear pricing } \\
\text { information, but non- } \\
\text { regulated institutions are } \\
\text { not subject to the same } \\
\text { rules. There has been a } \\
\text { significant effort to } \\
\text { enhance transparency } \\
\text { through Observatorio } \\
\text { Microfinananas, a } \\
\text { collaboration between } \\
\text { the and University of the } \\
\text { Republic, Participating } \\
\text { institutions publish } \\
\text { pricing information on a } \\
\text { quarterly basis. }\end{array}$ \\
\hline $\begin{array}{l}\text { Microcredit Sub-Index } \\
\text { Score }\end{array}$ & 1.1 & 1.2 & 1.1 & 1.6 & 1.3 & 1 & 1.9 & 1 \\
\hline
\end{tabular}




\section{Annex XII: Credit Reporting Systems: Summary of Regulatory Findings}

\begin{tabular}{|c|c|c|c|c|c|c|c|c|}
\hline Criteria/ Country & Argentina & Brazil & Chile & Colombia & Mexico & Paraguay & Peru & Uruguay \\
\hline $\begin{array}{l}\text { 1.Comprehensiveness of } \\
\text { information }\end{array}$ & 2 & 1.5 & 0.5 & 2 & 2 & 1 & 2 & 2 \\
\hline $\begin{array}{l}\text { 1A. Sources of } \\
\text { information }\end{array}$ & $\begin{array}{l}2 \text { Credit bureaus are } \\
\text { allowed to gather } \\
\text { information from } \\
\text { banks, financial } \\
\text { companies and other } \\
\text { sources (retailers and } \\
\text { utilities companies). } \\
\text { Financial institutions } \\
\text { under BCRA } \\
\text { supervision must report } \\
\text { monthly to the public } \\
\text { registry. }\end{array}$ & $\begin{array}{l}2 \text { Private bureaus are } \\
\text { allowed to gather } \\
\text { information from } \\
\text { institutions authorized by } \\
\text { the BCB and from other } \\
\text { sources (retailers and } \\
\text { utilities companies). The } \\
\text { public registry is runned } \\
\text { by the BCB, with } \\
\text { information from banks, } \\
\text { cooperatives, and other } \\
\text { financial institutions } \\
\text { including microenterprise } \\
\text { credit societies } \\
\text { (SCMEPPs). }\end{array}$ & $\begin{array}{l}1 \text { The public registry } \\
\text { contains information that } \\
\text { institutions under SBIF } \\
\text { supervision report } \\
\text { monthly. Private bureaus } \\
\text { can gather information } \\
\text { on financial obligations } \\
\text { from banks, financing } \\
\text { companies, savings and } \\
\text { loans cooperatives and } \\
\text { public institutions, as well } \\
\text { as from retailers, but not } \\
\text { from utilities companies. }\end{array}$ & $\begin{array}{l}2 \text { Relevant regulation } \\
\text { allows credit bureaus } \\
\text { to collect information } \\
\text { related to financial, } \\
\text { credit, commercial or } \\
\text { services. Therefore, } \\
\text { they are allowed to } \\
\text { gather information } \\
\text { provided by banks, } \\
\text { financial companies, } \\
\text { retailers and utilities } \\
\text { companies. }\end{array}$ & $\begin{array}{l}2 \text { Private bureaus - } \\
\text { sociedades de información } \\
\text { crediticia - can gather } \\
\text { information from } \\
\text { regulated and non- } \\
\text { regulated institutions, } \\
\text { commercial companies } \\
\text { that grant credit and } \\
\text { utilities companies. } \\
\text { Financial institutions } \\
\text { must report to at least } \\
\text { one bureau. }\end{array}$ & $\begin{array}{l}0.5 \text { There is a public registry } \\
\text { runned by the Central } \\
\text { Bank, with information } \\
\text { from institutions under its } \\
\text { supervision; and one } \\
\text { runned by INCOOP with } \\
\text { information only from } \\
\text { and for credit } \\
\text { cooperatives. Private } \\
\text { bureaus are allowed to } \\
\text { gather information from } \\
\text { banks and financial } \\
\text { institutions, but not from } \\
\text { non-regulated lenders }\end{array}$ & $\begin{array}{l}2 \text { Private bureaus can } \\
\text { gather information } \\
\text { from banks, financial } \\
\text { companies and other } \\
\text { sources (retailers and } \\
\text { utilities companies). } \\
\text { The public registry } \\
\text { contains information } \\
\text { from financial } \\
\text { institutions. The SBS } \\
\text { only consolidates the } \\
\text { information collected } \\
\text { monthly }\end{array}$ & $\begin{array}{l}2 \text { The public registry, } \\
\text { managed by the BCU, } \\
\text { contains monthly } \\
\text { information from } \\
\text { banks and other } \\
\text { financial companies, } \\
\text { including credit } \\
\text { cooperatives. Private } \\
\text { bureaus can gather } \\
\text { information provided } \\
\text { by banks, financial } \\
\text { companies and other } \\
\text { sources, such as } \\
\text { retailers and utilities } \\
\text { companies. }\end{array}$ \\
\hline $\begin{array}{l}\text { 1B. Nature of the } \\
\text { information }\end{array}$ & $\begin{array}{l}2 \text { Private bureaus can } \\
\text { gather positive as well } \\
\text { as negative information. } \\
\text { The latter can only } \\
\text { remain in the bureau } \\
\text { for five years, while } \\
\text { there is no fixed term } \\
\text { for the elimination of } \\
\text { positive information. } \\
\text { Financial institutions } \\
\text { inform on debtor } \\
\text { identification and on } \\
\text { the loan (amount, type, } \\
\text { performance, } \\
\text { guarantees, interest } \\
\text { rates, maturities). }\end{array}$ & $\begin{array}{l}0.5 \text { Financial institutions are } \\
\text { required to report both } \\
\text { positive and negative } \\
\text { information. Private } \\
\text { bureaus are allowed to } \\
\text { gather positive and } \\
\text { negative information, but } \\
\text { in practice only cover } \\
\text { negative data due to } \\
\text { obstacles arising from the } \\
\text { legislation of the Cadastro } \\
\text { Positivo. In late 2016, the } \\
\text { BCB issued a proposal on } \\
\text { this, not yet approved }\end{array}$ & $\begin{array}{l}\text { 0.5 The public credit registry, } \\
\text { Sistema de Deudores, covers } \\
\text { positive as well as } \\
\text { negative information } \\
\text { (debts past due, } \\
\text { outstanding debt, } \\
\text { guarantees and collateral } \\
\text { and assets and liabilities). } \\
\text { Private credit bureaus in } \\
\text { Chile are only allowed to } \\
\text { gather negative } \\
\text { information }\end{array}$ & $\begin{array}{l}2 \text { Private bureaus cover } \\
\text { positive and negative } \\
\text { information. The } \\
\text { latter must remain in } \\
\text { the bureaus for } \\
\text { double the time the } \\
\text { obligation has been } \\
\text { past due, with a } \\
\text { maximum of four } \\
\text { years. Positive } \\
\text { information must } \\
\text { remain indefinitely. }\end{array}$ & $\begin{array}{l}2 \text { Private credit bureaus } \\
\text { can cover positive and } \\
\text { negative information. } \\
\text { Financial institutions } \\
\text { are required to report } \\
\text { information on debts } \\
\text { past due and } \\
\text { obligations fulfilled. } \\
\text { Information on debts } \\
\text { past due or paid must } \\
\text { remain in the bureau } \\
\text { for at least } 72 \text { months }\end{array}$ & $\begin{array}{l}0.5 \text { BCP's registry is required } \\
\text { to gather positive and } \\
\text { negative information from } \\
\text { supervised institutions. } \\
\text { However, private credit } \\
\text { bureaus are only allowed } \\
\text { to gather negative } \\
\text { information by the law on } \\
\text { personal data. Rules on } \\
\text { banking secrecy also } \\
\text { create a legal obstacle to } \\
\text { the provision of positive } \\
\text { information in private } \\
\text { bureaus. }\end{array}$ & $\begin{array}{l}2 \text { The public credit } \\
\text { registry covers both } \\
\text { positive and negative } \\
\text { information, as it } \\
\text { registers the debts } \\
\text { contracted by users of } \\
\text { the financial system. } \\
\text { Private credit bureaus } \\
\text { are also allowed to } \\
\text { contain both positive } \\
\text { and negative } \\
\text { information }\end{array}$ & $\begin{array}{l}2 \text { Information reported } \\
\text { to the public registry } \\
\text { includes amounts } \\
\text { outstanding and } \\
\text { guarantees. Private } \\
\text { bureaus can contain } \\
\text { positive and negative } \\
\text { information of } \\
\text { commercial or credit } \\
\text { nature. This } \\
\text { information can remain } \\
\text { in the bureau for a } \\
\text { maximum of } 5 \text { year. }\end{array}$ \\
\hline 1C. Borrowers covered & $\begin{array}{l}2 \text { Under the BCRA's } \\
\text { Reporting Regime } \\
\text { debtors that must be } \\
\text { covered in the public } \\
\text { registry are natural and } \\
\text { legal persons, including } \\
\text { micro and SMEs; } \\
\text { except from debtors } \\
\text { with balance below } \\
1.000 \text { pesos. } \\
\text { Private bureaus can } \\
\text { cover information on } \\
\text { both natural and legal } \\
\text { persons, with no }\end{array}$ & $\begin{array}{l}2 \text { Financial institutions must } \\
\text { report information on } \\
\text { both natural and legal } \\
\text { persons. Since June 2016, } \\
\text { financial institutions must } \\
\text { provide information on } \\
\text { loans above R200 (USD } \\
\text { 55), broadening } \\
\text { information reported on } \\
\text { small borrowers. Private } \\
\text { bureaus can gather } \\
\text { information on natural } \\
\text { and legal persons, with no } \\
\text { limits on the amounts }\end{array}$ & $\begin{array}{l}0 \text { Credit bureaus and credit } \\
\text { registries gather } \\
\text { information on both } \\
\text { natural and legal persons. } \\
\text { A } 2012 \text { Law established } \\
\text { that credit bureaus } \\
\text { should not disclose } \\
\text { information on loans that } \\
\text { were delinquent before } \\
\text { end-2011 and do not } \\
\text { exceed } 2.5 \text { million pesos } \\
\text { (USD } 4000) \text {, limiting the } \\
\text { historical data available } \\
\text { on small loans. }\end{array}$ & $\begin{array}{l}2 \text { Private bureaus cover } \\
\text { information on both } \\
\text { firms and individuals, } \\
\text { and relevant } \\
\text { legislation does not } \\
\text { impose any limits on } \\
\text { the amount of the } \\
\text { loans to be reported. } \\
\text { NGOs offering } \\
\text { microcredit must } \\
\text { disclose information } \\
\text { on their clients } \\
\text { periodically. }\end{array}$ & $\begin{array}{l}2 \text { Private bureaus are } \\
\text { allowed to gather } \\
\text { information on both } \\
\text { natural and legal } \\
\text { persons. There is no } \\
\text { limitation in the law to } \\
\text { the amounts of the } \\
\text { loans on which } \\
\text { information can be } \\
\text { distributed. }\end{array}$ & $\begin{array}{l}2 \text { Private bureaus and the } \\
\text { public registry contain } \\
\text { information on both firms } \\
\text { and individuals. Both } \\
\text { distribute as well } \\
\text { information on loan } \\
\text { amounts below } 1 \% \text { of per } \\
\text { capita income. }\end{array}$ & $\begin{array}{l}\text { 2. Private bureaus and the } \\
\text { public registry contain } \\
\text { information on firms } \\
\text { and individuals. Both } \\
\text { distribute as well } \\
\text { information on loan } \\
\text { amounts below } 1 \% \text { of } \\
\text { per capita income. }\end{array}$ & $\begin{array}{l}2 \text { Private credit bureaus } \\
\text { can gather information } \\
\text { on both firms and } \\
\text { individuals. Banks and } \\
\text { other financial } \\
\text { institutions are required } \\
\text { to report information } \\
\text { on both firms and } \\
\text { individuals to the } \\
\text { public registry. Both } \\
\text { distribute as well } \\
\text { information on loan } \\
\text { amounts below } 1 \% \text { of } \\
\text { per capita income. }\end{array}$ \\
\hline
\end{tabular}




\begin{tabular}{|c|c|c|c|c|c|c|c|c|}
\hline Criteria/ Country & Argentina & Brazil & Chile & Colombia & Mexico & Paraguay & Peru & Uruguay \\
\hline 2. Accessibility and safety & 2 & 1.7 & 2 & 2 & 2 & 1.7 & 2 & 2 \\
\hline 2A. Borrowers' access & $\begin{array}{l}2 \text { Borrowers have the } \\
\text { right to access their } \\
\text { data in the credit } \\
\text { bureau and the credit } \\
\text { registry. This is } \\
\text { regulated under Law } \\
25326, \text { which states that } \\
\text { borrowers have the } \\
\text { right to access } \\
\text { information contained } \\
\text { on them, and request } \\
\text { for free an amendment } \\
\text { if mistaken information } \\
\text { is identified. }\end{array}$ & $\begin{array}{l}1 \text { Borrowers can access } \\
\text { their data in the credit } \\
\text { reporting systems and } \\
\text { modify for free mistaken } \\
\text { information. In the public } \\
\text { registry, it can be done } \\
\text { through the BCB's } \\
\text { Registrato in person, in } \\
\text { written or online } \\
\text { Individuals can also } \\
\text { request the reporting } \\
\text { financial institutions to } \\
\text { modify errors in the } \\
\text { registry, and if they fail to } \\
\text { reach an agreement, the } \\
\text { borrower can submit a } \\
\text { complaint to the Central } \\
\text { Bank. This results in a } \\
\text { process that is difficult } \\
\text { and time-consuming. }\end{array}$ & $\begin{array}{l}2 \text { Borrowers have the right } \\
\text { to access information on } \\
\text { them in the Debtors } \\
\text { System, in person or } \\
\text { online. } \\
\text { Borrowers have also the } \\
\text { right to access } \\
\text { information in the private } \\
\text { credit bureaus and have } \\
\text { any errors corrected free } \\
\text { of cost. Furthermore, } \\
\text { Law } 20575 \text { o o } 2012 \\
\text { established that private } \\
\text { credit bureaus must have } \\
\text { a designated person to } \\
\text { deal with data processing } \\
\text { and requests from } \\
\text { borrowers }\end{array}$ & $\begin{array}{l}2 \text { Borrowers have the } \\
\text { right to access their } \\
\text { data in the credit } \\
\text { bureaus, once a } \\
\text { month free of cost. } \\
\text { Borrowers can } \\
\text { request corrections } \\
\text { or updates by } \\
\text { submitting a claim to } \\
\text { the bureau (in } \\
\text { person, in written or } \\
\text { by any means) The } \\
\text { Law regulates the } \\
\text { number of days in } \\
\text { which the credit } \\
\text { bureau can solve the } \\
\text { claim and mandates } \\
\text { that the bureau } \\
\text { formally responds to } \\
\text { any claim. }\end{array}$ & $\begin{array}{l}2 \text { Borrowers can access } \\
\text { their data in the credit } \\
\text { bureaus and request } \\
\text { their "Special Credit } \\
\text { Report", in person, via } \\
\text { email or by mail, } \\
\text { provided for free once } \\
\text { a year. Borrowers can } \\
\text { present a claim if any } \\
\text { error is identified, and } \\
\text { the bureau is } \\
\text { mandated to channel } \\
\text { this claim to the } \\
\text { reporting entity. } \\
\text { Furthermore, private } \\
\text { bureaus are required to } \\
\text { process at least two } \\
\text { claims by client each } \\
\text { year. }\end{array}$ & $\begin{array}{l}1 \text { Borrowers can access their } \\
\text { data in the bureaus and in } \\
\text { the public registry. The } \\
\text { National Constitution } \\
\text { gives individuals the right } \\
\text { to modify any false public } \\
\text { information on them, and } \\
\text { this applies to the public } \\
\text { and private registries. } \\
\text { However, this right has } \\
\text { not been legislated and } \\
\text { there are no rules to } \\
\text { streamline the process of } \\
\text { requesting an update, } \\
\text { correction or elimination } \\
\text { of incorrect information. } \\
\text { As a result, the process is } \\
\text { costly and time- } \\
\text { consuming. }\end{array}$ & $\begin{array}{l}2 \text { Borrowers can access } \\
\text { their data in credit } \\
\text { bureaus and in the } \\
\text { public registry online } \\
\text { for free or with } \\
\text { minimum cost if } \\
\text { handed in hard copy, } \\
\text { and have any errors } \\
\text { corrected for free. In } \\
\text { the public registry } \\
\text { individuals must } \\
\text { present a claim to the } \\
\text { reporting financial } \\
\text { entity. Borrowers also } \\
\text { can present a claim to } \\
\text { the SBS, who will } \\
\text { assess if the reporting } \\
\text { entity is subject to an } \\
\text { administrative fine. }\end{array}$ & $\begin{array}{l}2 \text { Borrowers can access } \\
\text { their data in credit } \\
\text { bureaus and in the } \\
\text { public registry free of } \\
\text { cost every six months, } \\
\text { and have mistakes } \\
\text { corrected for free. In } \\
\text { the public registry, if } \\
\text { borrowers identify } \\
\text { errors, they must } \\
\text { contact the reporting } \\
\text { institution(s) and } \\
\text { provide the relevant } \\
\text { information to make } \\
\text { the correction. Each } \\
\text { institution must have a } \\
\text { service to handle } \\
\text { borrowers' claims, The } \\
\text { client can present the } \\
\text { claim to the SSF }\end{array}$ \\
\hline 2B. Lenders' access & $\begin{array}{l}2 \text { Banks and financial } \\
\text { companies are allowed } \\
\text { to access information } \\
\text { on borrowers from the } \\
\text { credit bureau and the } \\
\text { credit registry online. }\end{array}$ & $\begin{array}{l}2 \text { Banks and regulated } \\
\text { financial institutions have } \\
\text { the right to access the } \\
\text { data on borrowers } \\
\text { provided explicit } \\
\text { authorization. } \\
\text { Information contained in } \\
\text { private bureaus can only } \\
\text { be accesses by natural or } \\
\text { legal persons with whom } \\
\text { the borrower maintains a } \\
\text { commercial or credit } \\
\text { relationship }\end{array}$ & $\begin{array}{l}2 \text { Only banks and financial } \\
\text { companies can access } \\
\text { information on } \\
\text { borrowers from the } \\
\text { public credit registry. } \\
\text { Data contained in private } \\
\text { bureaus can only be used } \\
\text { for credit assessment, and } \\
\text { therefore can be accessed } \\
\text { by lenders. }\end{array}$ & $\begin{array}{l}2 \text { Banks and financial } \\
\text { companies are } \\
\text { allowed to access } \\
\text { information on } \\
\text { borrowers from the } \\
\text { credit bureaus. }\end{array}$ & $\begin{array}{l}2 \text { Only financial } \\
\text { institutions, } \\
\text { commercial companies } \\
\text { and non regulated } \\
\text { sofomes can access } \\
\text { information from the } \\
\text { bureau. They are only } \\
\text { allowed to access } \\
\text { information on a } \\
\text { borrower when this } \\
\text { borrower has given its } \\
\text { explicit authorization. }\end{array}$ & $\begin{array}{l}2 \text { Banks and financial } \\
\text { companies can access } \\
\text { information on borrowers } \\
\text { from the credit bureaus } \\
\text { and in the public registry, } \\
\text { according to the } \\
\text { regulation in place. }\end{array}$ & $\begin{array}{l}2 \text { Banks and financial } \\
\text { companies can access } \\
\text { information on } \\
\text { borrowers from the } \\
\text { credit bureaus and in } \\
\text { the public registry. }\end{array}$ & $\begin{array}{l}2 \text { Banks and financial } \\
\text { companies and other } \\
\text { credit companies are } \\
\text { allowed to access } \\
\text { information on } \\
\text { borrowers from the } \\
\text { credit bureaus and in } \\
\text { the public registry, as } \\
\text { regulated in the } \\
\text { relevant legislation. }\end{array}$ \\
\hline 2C. Data protection & $\begin{array}{l}2 \text { Law } 25326 \text { of } 2000 \text { sets } \\
\text { a framework for } \\
\text { personal data } \\
\text { protection that credit } \\
\text { bureaus must comply } \\
\text { with. }\end{array}$ & $\begin{array}{l}2 \text { Law no } 8078 \text { of } 1990 \text { on } \\
\text { Consumer Protection and } \\
\text { Law } 9507 \text { on Habeas data } \\
\text { set out strong rules on } \\
\text { privacy rights for both } \\
\text { borrowers and creditors, } \\
\text { applicable to the public } \\
\text { registry and private credit } \\
\text { bureaus. }\end{array}$ & $\begin{array}{l}2 \text { Law } 19628 \text { on the } \\
\text { protection of personal } \\
\text { data sets out rules on } \\
\text { privacy rights for } \\
\text { individuals that apply to } \\
\text { the existing credit } \\
\text { information systems. }\end{array}$ & $\begin{array}{l}2 \text { Law } 1581 \text { of } 2012 \text { on } \\
\text { privacy of personal } \\
\text { data applies to credit } \\
\text { bureaus. Compliance } \\
\text { with these rules is } \\
\text { overseen by the } \\
\text { Superintendencies of } \\
\text { Finance and of } \\
\text { Industry and } \\
\text { Commerce. }\end{array}$ & $\begin{array}{l}2 \text { A } 2002 \text { Law on credit } \\
\text { bureaus forbids these } \\
\text { to share personal } \\
\text { information for any } \\
\text { reason different to } \\
\text { checking a borrower's } \\
\text { credit history. Further } \\
\text { rules are set out in the } \\
\text { Federal Law on } \\
\text { Protection of Personal } \\
\text { Data. }\end{array}$ & $\begin{array}{l}2 \text { Law } 1682 \text { of } 2001 \text { on } \\
\text { private information states } \\
\text { privacy rights for } \\
\text { borrowers and lenders. } \\
\text { This Law establishes that } \\
\text { financial institutions } \\
\text { cannot obtain credit } \\
\text { reports of individuals who } \\
\text { are not their clients } \\
\text { whithout their explicit } \\
\text { consent. }\end{array}$ & $\begin{array}{l}2 \text { Law } 27489 \text { of } 2011 \\
\text { requires credit bureaus } \\
\text { to comply with } \\
\text { consumer protection } \\
\text { laws. Enforcement of } \\
\text { these laws is overseen } \\
\text { by the SBS and } \\
\text { Indecopi. }\end{array}$ & $\begin{array}{l}2 \text { Public and private } \\
\text { credit information } \\
\text { systems in Uruguay are } \\
\text { subject to Law } 18.331 \\
\text { of } 2008 \text { (Law } \\
\text { protecting personal } \\
\text { data), which guarantees } \\
\text { the right to respect } \\
\text { personal data. }\end{array}$ \\
\hline $\begin{array}{l}\text { Credit Reporting Systems } \\
\text { Sub-index Score }\end{array}$ & 2 & 1.6 & 1.3 & 2 & 2 & 1.4 & 2 & 2 \\
\hline
\end{tabular}




\section{Annex XIII: Simplified KYC Requirements: Summary of Regulatory Findings}

\begin{tabular}{|c|c|c|c|c|c|c|c|c|}
\hline Criteria/ Country & Argentina & Brazil & Chile & Colombia & Mexico & Paraguay & Peru & Uruguay \\
\hline 1. Level Playing Field & $\begin{array}{l}2 \text { KYC rules are } \\
\text { equivalent across } \\
\text { providers of financial } \\
\text { services. According to } \\
\text { the FATF latest Mutual } \\
\text { Evaluation of Argentina } \\
\text { in 2014, provisions on } \\
\text { KYC applicable to } \\
\text { different sectors } \\
\text { (banking and other } \\
\text { financial intermediaries, } \\
\text { exchange, insurance and } \\
\text { securities sectors) are } \\
\text { equivalent }\end{array}$ & $\begin{array}{l}2 \text { KYC rules are } \\
\text { equivalent across } \\
\text { providers of financial } \\
\text { services. Relevant } \\
\text { legislation is } \\
\text { applicable to all } \\
\text { institutions authorized } \\
\text { to operate by the } \\
\text { Central Bank, } \\
\text { including banks, } \\
\text { cooperatives and } \\
\text { other financing } \\
\text { companies, and } \\
\text { payment institutions. }\end{array}$ & $\begin{array}{l}2 \text { Rules from the SBIF on } \\
\text { KYC apply only to banks, } \\
\text { while law } 19.913 \text { on the } \\
\text { UAF has a broader scope. } \\
\text { However, this Law does } \\
\text { not regulate customer due } \\
\text { diligence. Rules on the } \\
\text { latter differ for each type } \\
\text { of institutions (i.e. banks, } \\
\text { insurance companies, } \\
\text { securities companies are } \\
\text { subject to different rules). } \\
\text { According to local experts, } \\
\text { the different regulatory } \\
\text { frameworks provide for } \\
\text { similar rules as regards } \\
\text { KYC }\end{array}$ & $\begin{array}{l}2 \text { KYC rules in Colombia } \\
\text { are applicable to all } \\
\text { institutions that provide } \\
\text { financial services and are } \\
\text { under the supervision of } \\
\text { the SFC. Furthermore, } \\
\text { exemptions under which } \\
\text { it is possible to follow a } \\
\text { simplified CDD } \\
\text { procedure are defined } \\
\text { on the basis of the type } \\
\text { and nature of the } \\
\text { product, and not } \\
\text { depending on the } \\
\text { financial institution that } \\
\text { offers it. }\end{array}$ & $\begin{array}{l}2 \text { There are different } \\
\text { standards and } \\
\text { regulators for each type } \\
\text { of financial institution. } \\
\text { According to the latest } \\
\text { FATF Mutual } \\
\text { Evaluation for Mexico } \\
\text { (2014), rules on KYC } \\
\text { for the different sectors } \\
\text { are to a great degree } \\
\text { identical, including on } \\
\text { CDD measures, even if } \\
\text { contained in different } \\
\text { legislative acts. }\end{array}$ & $\begin{array}{l}0 \text { Laws on AML/CFT apply } \\
\text { to banks, financial } \\
\text { companies, insurance } \\
\text { companies, cooperatives } \\
\text { and other institutions, } \\
\text { contain the obligation of } \\
\text { all these institutions to } \\
\text { identify their clients. } \\
\text { However, more detailed } \\
\text { regulations differ for } \\
\text { institutions supervised by } \\
\text { the Central Bank and for } \\
\text { cooperatives supervised by } \\
\text { INCOOP. There is no } \\
\text { simplified due diligence } \\
\text { regime for cooperatives. }\end{array}$ & $\begin{array}{l}2 \text { Resolution No } 2660- \\
2015 \text { on anti-money } \\
\text { laundering rules applies } \\
\text { to all the enterprises } \\
\text { under the supervision } \\
\text { of the SBS (banks, } \\
\text { financing companies, } \\
\text { cajas, EDPYMEs, } \\
\text { cooperatives, insurance } \\
\text { companies, issuers of } \\
\text { credit/debit cards and } \\
\text { electronic money } \\
\text { issuers. }\end{array}$ & $\begin{array}{l}2 \text { The relevant } \\
\text { legislation is of } \\
\text { application to all } \\
\text { natural and legal } \\
\text { persons under the } \\
\text { supervision of the } \\
\text { BCU, as mandated } \\
\text { by articles } 1 \text { and } 2 \text { of } \\
\text { Law } 18494 \text {. This } \\
\text { includes banks, } \\
\text { cooperatives and } \\
\text { electronic money } \\
\text { issuers, among } \\
\text { others. }\end{array}$ \\
\hline $\begin{array}{l}\text { 2. Identification } \\
\text { requirements }\end{array}$ & $\begin{array}{l}2 \text { Rules on KYC allow the } \\
\text { application of simplified } \\
\text { due diligence for client } \\
\text { identification for the } \\
\text { opening of cajas de aborro } \\
\text { (simplified accounts), } \\
\text { based on the } \\
\text { presentation of the } \\
\text { national identification } \\
\text { document. }\end{array}$ & $\begin{array}{l}1 \text { There is not a } \\
\text { simplified CDD } \\
\text { procedure in Chilean } \\
\text { rules, but financial } \\
\text { institutions can } \\
\text { identify low-risk } \\
\text { financial services } \\
\text { which may be exempt } \\
\text { from some } \\
\text { information } \\
\text { requirements. } \\
\text { Information required } \\
\text { for simplified } \\
\text { accounts includes: } \\
\text { basic identification } \\
\text { information, number } \\
\text { of inscription on the } \\
\text { Cadastro de Pesso Fissica } \\
\text { and information on } \\
\text { marital status, } \\
\text { occupation, address } \\
\text { and signature. }\end{array}$ & $\begin{array}{l}2 \text { There is no simplified due } \\
\text { diligence recognized in } \\
\text { local regulations. } \\
\text { However, SBIF rules on } \\
\text { KYC recognize that when } \\
\text { justified by the nature, } \\
\text { characteristics and risks of } \\
\text { the products and services, } \\
\text { some requirements might } \\
\text { not be imposed, for } \\
\text { instance, institutions may } \\
\text { be allowed not to request } \\
\text { a photo or the digital } \\
\text { fingerprint. } \\
\text { Following this, } \\
\text { BancoEstado's RUT } \\
\text { accounts can be opened } \\
\text { solely with the identity } \\
\text { card. }\end{array}$ & $\begin{array}{l}2 \text { Simplified CDD is } \\
\text { recognized in some } \\
\text { cases: special insurance } \\
\text { types, deposit accounts } \\
\text { with a simplified } \\
\text { opening (CATS), } \\
\text { electronic savings } \\
\text { accounts (CAE), } \\
\text { electronic deposits (e- } \\
\text { money), and low-value } \\
\text { consumption credit. } \\
\text { However, KYC rules do } \\
\text { not define information } \\
\text { to be collected in these } \\
\text { cases. Instead this is } \\
\text { regulated under the } \\
\text { regulation of each } \\
\text { product. In the case if } \\
\text { simplified electronic } \\
\text { deposits, CATS and } \\
\text { CAE, information } \\
\text { required is: name and } \\
\text { type, number and date } \\
\text { of the identity } \\
\text { document. Record of } \\
\text { signatures or fingerprints } \\
\text { is not required for these. }\end{array}$ & $\begin{array}{l}2 \text { There is not a unique } \\
\text { simplified KYC regime, } \\
\text { but instead, credit } \\
\text { institutions are exempt } \\
\text { of certain identification } \\
\text { requirements } \\
\text { depending on the level } \\
\text { of risk of each product } \\
\text { offered. In the case of } \\
\text { Level 1, accounts } \\
\text { institutions are not } \\
\text { required to identify the } \\
\text { client. The data to be } \\
\text { provided in the case of } \\
\text { level } 2 \text { accounts are: } \\
\text { full name, date of birth } \\
\text { and address, which } \\
\text { must be obtained from } \\
\text { an official } \\
\text { identification. These } \\
\text { requirements may also } \\
\text { apply to microloans for } \\
\text { natural persons. }\end{array}$ & $\begin{array}{l}1 \text { There is a simplified KYC } \\
\text { procedure for all entities } \\
\text { supervised by Central } \\
\text { Bank, which can be } \\
\text { applied to low-risk } \\
\text { customers. The simplified } \\
\text { procedures of KYC still } \\
\text { require the customer } \\
\text { identification form along } \\
\text { with a copy of the } \\
\text { identification document, } \\
\text { proof of income or } \\
\text { commercial activity } \\
\text { However, there is not a } \\
\text { simplified due diligence } \\
\text { regime for cooperatives, } \\
\text { which according to the } \\
\text { World Bank (2014) could } \\
\text { facilitate the opening of } \\
\text { accounts for populations } \\
\text { in rural areas. }\end{array}$ & $\begin{array}{l}2 \text { SBS Resolution } \mathrm{N}^{\circ} \\
2660-2015 \text { establishes } \\
\text { that companies will be } \\
\text { allowed to employ } \\
\text { reduced due diligence } \\
\text { arrangements when its } \\
\text { risk level allows it in } \\
\text { accordance to the } \\
\text { Superintendence's } \\
\text { regulations. Minimal } \\
\text { information to be } \\
\text { obtained from natural } \\
\text { person customers } \\
\text { includes: a) full name; } \\
\text { b) identification } \\
\text { document number and } \\
\text { type; and c) address. In } \\
\text { order to identify a } \\
\text { customer, an } \\
\text { identification } \\
\text { document should be } \\
\text { provided in case of } \\
\text { natural persons. }\end{array}$ & $\begin{array}{l}2 \text { Simplified due } \\
\text { diligence applies to } \\
\text { simplified savings } \\
\text { accounts for } \\
\text { individuals and small } \\
\text { enterprises, as well } \\
\text { as for electronic } \\
\text { money instruments } \\
\text { for payment of } \\
\text { payroll, professional } \\
\text { fees, passivities and } \\
\text { social benefits. } \\
\text { In these cases, } \\
\text { information to be } \\
\text { requested for } \\
\text { individual persons is } \\
\text { based on the } \\
\text { following } \\
\text { information: full } \\
\text { name, date and place } \\
\text { of birth, identity } \\
\text { document, address } \\
\text { and telephone } \\
\text { number. Individuals } \\
\text { must also present a } \\
\text { copy of the } \\
\text { identification } \\
\text { document. }\end{array}$ \\
\hline
\end{tabular}




\begin{tabular}{|c|c|c|c|c|c|c|c|c|}
\hline Criteria/ Country & Argentina & Brazil & Chile & Colombia & Mexico & Paraguay & Peru & Uruguay \\
\hline 3. Verification requirements & $\begin{array}{l}2 \text { Regulation provides a } \\
\text { list of valid } \\
\text { identification } \\
\text { documents, of which } \\
\text { the individual must } \\
\text { present the original and } \\
\text { provide a copy. For } \\
\text { simplified CDD } \\
\text { procedures, the relevant } \\
\text { identification document } \\
\text { is the Documento Nacional } \\
\text { de Identidad. The latter is } \\
\text { the primary } \\
\text { identification document } \\
\text { that every Argentine } \\
\text { citizen has since birth. } \\
\text { According to the World } \\
\text { Bank ID4D Database, } \\
\text { the ID is provided at a } \\
\text { cost of ARS } 35 \text { (USD 9) }\end{array}$ & $\begin{array}{l}2 \text { Original } \\
\text { documentation is } \\
\text { required as part of the } \\
\text { verification process. } \\
\text { In the case of natural } \\
\text { persons, identity is to } \\
\text { be verified against the } \\
\text { National Civil } \\
\text { Identification } \\
\text { Document. Its } \\
\text { emission is the } \\
\text { responsibility of the } \\
\text { federal states, but it is } \\
\text { valid throughout the } \\
\text { national territory. } \\
\text { According to the } \\
\text { World Bank ID4D } \\
\text { Database, this } \\
\text { document is } \\
\text { mandatory for all } \\
\text { individuals over } 18, \\
\text { and it is obtained at a } \\
\text { reasonable cost (varies } \\
\text { depending on the } \\
\text { state) }\end{array}$ & $\begin{array}{l}0 \text { SBIF rules on KYC state } \\
\text { that financial institutions } \\
\text { must ensure the } \\
\text { verification of the } \\
\text { information provided by } \\
\text { the client, by the means } \\
\text { that the institution } \\
\text { considers appropriate, but } \\
\text { does not specify further. }\end{array}$ & $\begin{array}{l}0 \text { Under the general CDD } \\
\text { regime, entities verify } \\
\text { the information with the } \\
\text { original identification in } \\
\text { the personal interview. } \\
\text { Under the simplified } \\
\text { regime, there is no need } \\
\text { to conduct personal } \\
\text { interviews or to } \\
\text { complete the } \\
\text { identification form. } \\
\text { Howwever, the regulation } \\
\text { is not clear about how } \\
\text { financial institutions can } \\
\text { verify customers' } \\
\text { identity. }\end{array}$ & $\begin{array}{l}\text { 1.5 Under the simplified } \\
\text { CDD regime, credit } \\
\text { institutions must verify } \\
\text { the validity of the data } \\
\text { via electronic means } \\
\text { with the National } \\
\text { Registry of the } \\
\text { Population (Renapo) to } \\
\text { integrate the Clave } \\
\text { Única del Registrro de } \\
\text { Población del cliente } \\
\text { (CURP). Identity fraud } \\
\text { problems have recently } \\
\text { been reported, due to } \\
\text { the lack of a secure } \\
\text { national identity card. } \\
\text { In } 2017 \text {, the } \\
\text { AML/CFT rules for } \\
\text { banks have been } \\
\text { modified to allow a } \\
\text { broader range of valid } \\
\text { identification } \\
\text { documents }\end{array}$ & $\begin{array}{l}2 \text { Financial institutions must } \\
\text { require new clients to } \\
\text { submit original documents } \\
\text { or copies certified by a } \\
\text { notary of their } \\
\text { identification documents } \\
\text { (cedula de indentidad), which } \\
\text { is mandatory for all } \\
\text { individuals over 18. The } \\
\text { problem is that financial } \\
\text { institutions do not have } \\
\text { access to a national } \\
\text { database to verify the } \\
\text { authenticity of the ID } \\
\text { documents. Furthermore, } \\
\text { demanding a copy of the } \\
\text { ID card may be } \\
\text { cumbersome for the } \\
\text { population in rural areas. }\end{array}$ & $\begin{array}{l}2 \text { Verification also } \\
\text { follows a risk-based } \\
\text { approach. Under the } \\
\text { simplified CDD } \\
\text { regime, verification is } \\
\text { based on the } \\
\text { presentation of the } \\
\text { identification } \\
\text { document.According } \\
\text { to information } \\
\text { provided by the World } \\
\text { Bank ID4D Database, } \\
\text { the latter is mandatory } \\
\text { for individuals older } \\
\text { than } 17 . \text { RENIEC } \\
\text { National Registry of } \\
\text { Identification and Civil } \\
\text { Status) is the } \\
\text { responsible body for } \\
\text { the national ID system, } \\
\text { which is based on } \\
\text { biometrics to ensure } \\
\text { uniqueness. The ID is } \\
\text { free the first time. }\end{array}$ & $\begin{array}{l}2 \text { Relevant legislation } \\
\text { states that financial } \\
\text { institutions must } \\
\text { verify the identity of } \\
\text { their clients, but } \\
\text { does not specify } \\
\text { under which } \\
\text { mechanisms. } \\
\text { Individuals are } \\
\text { required to present } \\
\text { copies of their } \\
\text { national } \\
\text { identification } \\
\text { document. } \\
\text { The Uruguay } \\
\text { Identity Card is } \\
\text { issued by the } \\
\text { Ministry of the } \\
\text { Interior and the } \\
\text { National Directorate } \\
\text { of Civil } \\
\text { Identification } \\
\text { (D.N.I.C.), is } \\
\text { mandatory for all } \\
\text { inhabitants of } \\
\text { Uruguay, has a cost } \\
\text { of UYU \$ } 108 \text { (USD } \\
5.19 \text { and is based on } \\
\text { biometrics to } \\
\text { prevent identity } \\
\text { theft. }\end{array}$ \\
\hline $\begin{array}{l}\text { 4. Record-Keeping } \\
\text { requirements }\end{array}$ & $\begin{array}{l}2 \text { Rules on KYC impose } \\
\text { the need to maintain } \\
\text { information and } \\
\text { documentation on } \\
\text { clients' identification for } \\
\text { a minimum period of } 10 \\
\text { years, but it does not } \\
\text { specify whether these } \\
\text { records must be kept in } \\
\text { physical or electronic } \\
\text { format }\end{array}$ & $\begin{array}{l}2 \text { Rules on KYC } \\
\text { mandate financial } \\
\text { institutions to } \\
\text { maintain and keep } \\
\text { records and } \\
\text { information on the } \\
\text { process of } \\
\text { identification of the } \\
\text { client for a minimum } \\
\text { period of } 5 \text { years. } \\
\text { However, relevant } \\
\text { legislation does not } \\
\text { impose the physical } \\
\text { retention of the } \\
\text { documentation. }\end{array}$ & $\begin{array}{l}0 \text { Relevant regulation does } \\
\text { not define record-keeping } \\
\text { requirements }\end{array}$ & $\begin{array}{l}0 \text { Record-keeping } \\
\text { requirements impose the } \\
\text { retention of physical } \\
\text { copy of the } \\
\text { documentation provided } \\
\text { for the identification of } \\
\text { clients for a minimum } \\
\text { period of } 5 \text { years. }\end{array}$ & $\begin{array}{l}2 \text { Credit institutions must } \\
\text { keep, as part of the } \\
\text { identification file of } \\
\text { each client, the } \\
\text { information and } \\
\text { documents requested } \\
\text { and a document that } \\
\text { contains the results of } \\
\text { the interviews } \\
\text { conducted. However, } \\
\text { relevant legislation } \\
\text { does not impose the } \\
\text { retention of the } \\
\text { physical } \\
\text { documentation. }\end{array}$ & $\begin{array}{l}2 \text { KYC regulations state that } \\
\text { customers must provide } \\
\text { documentation proving } \\
\text { the veracity of the } \\
\text { information, which may be } \\
\text { original documents or } \\
\text { notarized copies, which } \\
\text { financial institutions must } \\
\text { keep for a minimum } \\
\text { period of } 5 \text {. }\end{array}$ & $\begin{array}{l}2 \text { Record-keeping } \\
\text { requirements are } \\
\text { streamlined, since rules } \\
\text { on KYC allow financial } \\
\text { institutions to maintain } \\
\text { records of clients' } \\
\text { identification and } \\
\text { verification by } \\
\text { electronic means or } \\
\text { through retention of } \\
\text { physical copies. }\end{array}$ & $\begin{array}{l}2 \text { Financial institutions } \\
\text { are obliged to keep } \\
\text { all the information } \\
\text { and relevant } \\
\text { documentation used } \\
\text { to verify clients' } \\
\text { information during } \\
\text { the CDD procedure } \\
\text { for a minimum term } \\
\text { of } 5 \text { years at the } \\
\text { establishment of the } \\
\text { financial institution. } \\
\text { However, relevant } \\
\text { legislation does not } \\
\text { impose the physical } \\
\text { retention of the } \\
\text { documentation. }\end{array}$ \\
\hline $\begin{array}{l}\text { Simplified KYC Sub-Index } \\
\text { Score }\end{array}$ & 2 & 1.8 & 1 & 1 & 1.9 & 1.3 & 2 & 2 \\
\hline
\end{tabular}




\section{Annex XIV: Financial Literacy: Summary of Regulatory Findings}

\begin{tabular}{|c|c|c|c|c|c|c|c|c|}
\hline Criteria/ Cou & Argentina & Brazil & Chile & Colombia & Mexico & Paraguay & Peru & Uruguay \\
\hline $\begin{array}{l}\text { 1. Financial Ed. } \\
\text { Capacity }\end{array}$ & 0.5 & 2 & 1.3 & 1.3 & 1.3 & 0.5 & 2 & 0.5 \\
\hline $\begin{array}{l}1 \mathrm{~A} . \\
\text { Institutional } \\
\text { Framework }\end{array}$ & $\begin{array}{l}1 \text { There is not a } \\
\text { coordinated policy } \\
\text { response in Argentina } \\
\text { to promote financial } \\
\text { education and no } \\
\text { specific authority has a } \\
\text { formal legal mandate } \\
\text { and earmarked } \\
\text { resources for it. The } \\
\text { BCRA, the Securities } \\
\text { Commission (CNV) } \\
\text { and the Ministry of } \\
\text { Education have } \\
\text { implemented some } \\
\text { initiatives to increase } \\
\text { financial knowledge } \\
\text { among the general } \\
\text { public, but these are } \\
\text { isolated, more limited } \\
\text { and with little } \\
\text { diffusion. }\end{array}$ & $\begin{array}{l}2 \text { Brazil officially } \\
\text { established a national } \\
\text { strategy for financial } \\
\text { education (ENEF) in } \\
2010 \text { through a } \\
\text { Presidential Decree, } \\
\text { under the responsibility } \\
\text { of a Working Group } \\
\text { coordinated by the } \\
\text { Brazilian securities and } \\
\text { exchange commission } \\
\text { (CVM) and composed } \\
\text { of financial sector } \\
\text { regulators and several } \\
\text { Ministries. }\end{array}$ & $\begin{array}{l}\text { The development of a } \\
\text { national strategy began in } \\
\text { 2012, but it is still been } \\
\text { drafted. In 2014, an } \\
\text { advisory commission for } \\
\text { financial inclusion } \\
\text { (CAPIF) was created by } \\
\text { Decree } 954 \text { as an } \\
\text { intergovernmental body } \\
\text { whose objectives include } \\
\text { the development of a } \\
\text { national strategy for } \\
\text { financial education. } \\
\text { Financial sector } \\
\text { regulators have } \\
\text { implemented financial } \\
\text { education initiatives in } \\
\text { their sectors, but these } \\
\text { initiatives could benefit } \\
\text { from the establishment } \\
\text { of a national framework. }\end{array}$ & $\begin{array}{l}\text { 1.5 In } 2010 \text { several public } \\
\text { institutions issued a } \\
\text { joint proposal for } \\
\text { implementing a } \\
\text { national strategy to } \\
\text { rationalize and } \\
\text { coordinate the } \\
\text { initiatives already in } \\
\text { place. In 2014, the } \\
\text { Intersectoral } \\
\text { Commission on } \\
\text { Economic and } \\
\text { Financial Education } \\
\text { was created. Despite } \\
\text { these advances, there } \\
\text { is room for } \\
\text { improvement in } \\
\text { achieving a } \\
\text { coordinated, broad } \\
\text { and robust approach, } \\
\text { which may be } \\
\text { achieved by a new } \\
\text { Strategy issued for } \\
\text { comments in May } \\
\text { 2017. }\end{array}$ & $\begin{array}{l}\text { 1.5 The Committee for } \\
\text { Financial Education } \\
\text { (CEF), set up in 2011, is } \\
\text { composed of the Ministry } \\
\text { of Finance and financial } \\
\text { regulatory commissions. } \\
\text { No National Financial } \\
\text { Education Strategy is in } \\
\text { place, but this is one of } \\
\text { the pillars of the Financial } \\
\text { Inclusion Strategy. The } \\
\text { upcoming financial } \\
\text { education strategy will } \\
\text { likely aim to: implement } \\
\text { new programs for target } \\
\text { sectors, coordinate public } \\
\text { and private actions and } \\
\text { define delivery tools. } \\
\text { Relevant authorities have } \\
\text { implemented several } \\
\text { initiatives. }\end{array}$ & $\begin{array}{l}1 \text { No public institution has } \\
\text { a legal mandate or } \\
\text { earmarked funds to } \\
\text { promote financial } \\
\text { education. The World } \\
\text { Bank recommended in } \\
2015 \text { to give the Central } \\
\text { Bank and the INCOOP } \\
\text { an explicit legal mandate, } \\
\text { but this has not yet been } \\
\text { regulated. The same } \\
\text { report also stated that } \\
\text { existing financial } \\
\text { education policies were } \\
\text { small and fragmented, } \\
\text { and that limited } \\
\text { coordination limited their } \\
\text { effectiveness. A working } \\
\text { group on financial } \\
\text { education was set up to } \\
\text { start preparing a national } \\
\text { strategy for financial } \\
\text { education, which has not } \\
\text { been finalized yet. }\end{array}$ & $\begin{array}{l}2 \text { The } 2015 \text { National } \\
\text { Financial Inclusion } \\
\text { Strategy (ENIF) also } \\
\text { aims at improving by } \\
\text { Financial Education, } \\
\text { through the work of the } \\
\text { SBS and the Ministry of } \\
\text { Education. Its objectives } \\
\text { are oriented to improve } \\
\text { the capacities, attitudes } \\
\text { and financial knowledge } \\
\text { of all the segments of the } \\
\text { population. The ENIF } \\
\text { also established a } \\
\text { Financial Education } \\
\text { Thematic Technical } \\
\text { Group and developed } \\
\text { the National Financial } \\
\text { Education Plan } \\
\text { (PLANEF), approved in } \\
\text { September 2016. }\end{array}$ & $\begin{array}{l}1 \text { Uruguay does not have } \\
\text { a financial education } \\
\text { strategy, but the } \\
\text { Central Bank has } \\
\text { embarked on an } \\
\text { Economic and } \\
\text { Financial Education } \\
\text { Program (BCU Educa). } \\
\text { It provides } \\
\text { information on the } \\
\text { functions performed } \\
\text { by the BCU, the } \\
\text { administration of } \\
\text { money and the use of } \\
\text { financial elements. On } \\
\text { the latter "BCU } \\
\text { Educa" includes } \\
\text { another portal called } \\
\text { "Usuario Financiero", } \\
\text { to provide information } \\
\text { on products and } \\
\text { services for the user of } \\
\text { the Uruguayan } \\
\text { Financial System. }\end{array}$ \\
\hline $\begin{array}{l}\text { 1B. } \\
\text { Coordination }\end{array}$ & $\begin{array}{l}0 \text { There is no formal } \\
\text { mechanism for cross- } \\
\text { sectorial coordination } \\
\text { of relevant public } \\
\text { authorities, beyond } \\
\text { specific agreements } \\
\text { between the Ministry } \\
\text { of Education and the } \\
\text { Central Bank for the } \\
\text { promotion of financial } \\
\text { knowledge in schools. } \\
\text { No specific effort has } \\
\text { been made to promote } \\
\text { or coordinate initiatives } \\
\text { from the private sector }\end{array}$ & $\begin{array}{l}2 \text { The National } \\
\text { Committee on } \\
\text { Financial Education is } \\
\text { composed of } \\
\text { representatives from } \\
\text { the public (including } \\
\text { Ministries and financial } \\
\text { sector regulators) and } \\
\text { private sector } \\
\text { representatives from } \\
\text { the capital market, } \\
\text { stock-exchange } \\
\text { insurance and bank } \\
\text { sectors. Private sector } \\
\text { agents operate under } \\
\text { the monitoring of } \\
\text { public authorities. }\end{array}$ & $\begin{array}{l}1 \text { CAPIF is mandated to } \\
\text { coordinate the work of } \\
\text { relevant public } \\
\text { authorities (Ministers of } \\
\text { Finance, Social } \\
\text { Development, } \\
\text { Education, Economy, } \\
\text { and Labor, the Central } \\
\text { Bank and financial } \\
\text { authorities, etc.) } \\
\text { Although Decree } 954 \\
\text { states that CAPIF may } \\
\text { invite relevant actors } \\
\text { from the private sector, } \\
\text { this participation does } \\
\text { not appear to be actively } \\
\text { promoted or monitored. }\end{array}$ & $\begin{array}{l}1 \text { The Intersectoral } \\
\text { Commission on } \\
\text { Economic and } \\
\text { Financial Education, } \\
\text { formed by different } \\
\text { public entities and the } \\
\text { private sector } \\
\text { coordinates public } \\
\text { and private } \\
\text { institutions' actions. } \\
\text { There are no } \\
\text { standards to monitor } \\
\text { private sector's } \\
\text { actions, even if this } \\
\text { was recognized in the } \\
2010 \text { proposal. }\end{array}$ & $\begin{array}{l}1 \text { The } 2014 \text { financial reform } \\
\text { establishes that the } \\
\text { National Council for } \\
\text { Financial Inclusion must } \\
\text { coordinate with the } \\
\text { Committee for Financial } \\
\text { Education., as well as } \\
\text { establish coordination } \\
\text { mechanisms among } \\
\text { public authorities and } \\
\text { with the private sector. } \\
\text { However, there is no } \\
\text { mention to the need of } \\
\text { ensuring an appropriate } \\
\text { supervision of the private } \\
\text { sector. }\end{array}$ & $\begin{array}{l}0 \text { There is no formal } \\
\text { mechanism for cross- } \\
\text { sectorial coordination of } \\
\text { relevant public } \\
\text { authorities. A number of } \\
\text { public and private } \\
\text { stakeholders are } \\
\text { providing financial } \\
\text { capability training and } \\
\text { education, but mostly as } \\
\text { stand-alone initiatives. } \\
\text { The BCP has signed } \\
\text { Memoranda of } \\
\text { Understanding with } \\
\text { individual ministries and } \\
\text { other stakeholders }\end{array}$ & $\begin{array}{l}2 \text { The SBS and the } \\
\text { Ministry of Education } \\
\text { are the leaders of the } \\
\text { Financial Technical } \\
\text { Thematic Group of } \\
\text { ENIF. Both agencies are } \\
\text { in charge of } \\
\text { implementing PLANEF } \\
\text { under the direction of } \\
\text { the Multisectorial } \\
\text { Commission for } \\
\text { Financial Inclusion. This } \\
\text { is compounded by the } \\
\text { efforts of public and } \\
\text { private sector actors. }\end{array}$ & $\begin{array}{l}0 \text { There is no formal } \\
\text { mechanism for cross- } \\
\text { sectoral coordination } \\
\text { of relevant public } \\
\text { authorities, beyond } \\
\text { some specific } \\
\text { agreements between } \\
\text { the Central Bank and } \\
\text { national educational } \\
\text { institutions, both } \\
\text { public and private, to } \\
\text { carry out financial } \\
\text { education projects for } \\
\text { primary and secondary } \\
\text { education and teacher } \\
\text { training. }\end{array}$ \\
\hline
\end{tabular}




\begin{tabular}{|c|c|c|c|c|c|c|c|c|}
\hline Criteria/ Count & Argentina & Brazil & Chile & Colombia & Mexico & Paraguay & Peru & Uruguay \\
\hline 2. Policy Efforts & 1.3 & 2 & 1.3 & 1.7 & 1.7 & 1.3 & 2 & 1 \\
\hline 2A. Target & $\begin{array}{l}1 \text { The most common } \\
\text { target group is children } \\
\text { at schools. The BCRA } \\
\text { began in } 2008 \text { to visit } \\
\text { educational } \\
\text { establishments under } \\
\text { the slogan "Central } \\
\text { Bank goes to school". } \\
\text { BCRA also has the } \\
\text { BCRA Educa website } \\
\text { with educational } \\
\text { material for children, } \\
\text { young people and } \\
\text { teachers. All other } \\
\text { initiatives are addressed } \\
\text { at the general public. }\end{array}$ & $\begin{array}{l}2 \text { Providing financial } \\
\text { education in the formal } \\
\text { school is central in the } \\
\text { national strategy. } \\
\text { Private sector } \\
\text { associations have } \\
\text { collaborated in the } \\
\text { implementation of this } \\
\text { action. There is also an } \\
\text { Adult Financial } \\
\text { Education Program } \\
\text { with two priority target } \\
\text { groups: women } \\
\text { beneficiaries of Bolsa } \\
\text { Familia and retirees } \\
\text { with low income. }\end{array}$ & $\begin{array}{l}0 \text { Regulation on the } \\
\text { financial education } \\
\text { framework does not } \\
\text { identify relevant target } \\
\text { groups such as the youth, } \\
\text { young adults, people in } \\
\text { "learning environments" } \\
\text { or vulnerable sectors. } \\
\text { Also, there has not been } \\
\text { yet a formal effort to } \\
\text { introduce financial } \\
\text { education in the school } \\
\text { program, although Chile } \\
\text { participated in the } \\
\text { financial literacy option } \\
\text { in the } 2015 \text { PISA test. }\end{array}$ & $\begin{array}{l}1 \text { Financial education } \\
\text { programs focus on } \\
\text { the general public or } \\
\text { students in high-level } \\
\text { education, while other } \\
\text { relevant audiences are } \\
\text { not usually targeted. } \\
\text { The 2010 National } \\
\text { Development Plan } \\
\text { mandated the } \\
\text { Education Ministry to } \\
\text { define the basic } \\
\text { competences for } \\
\text { students, but this } \\
\text { effort has not } \\
\text { materialized }\end{array}$ & $\begin{array}{l}1 \text { The } 2013 \text { National } \\
\text { Development Plan (PND) } \\
\text { seeks to include financial } \\
\text { education in basic and } \\
\text { intermediate education } \\
\text { programmes and } \\
\text { strengthening the } \\
\text { financial education of } \\
\text { women. However, no } \\
\text { specific advances have } \\
\text { been made yet. The } \\
\text { Public Education } \\
\text { Secretariat implements a } \\
\text { program since } 2008 \text { with } \\
\text { the same aim. No other } \\
\text { target groups are } \\
\text { identified. Other } \\
\text { programs are targeted to } \\
\text { the general public. }\end{array}$ & $\begin{array}{l}1 \text { The Central Bank and } \\
\text { the Ministry of } \\
\text { Education developed an } \\
\text { optional program of } \\
\text { Economic and Financial } \\
\text { Education for Middle } \\
\text { School. } \\
\text { In } 2017 \text { a one-month } \\
\text { financial education } \\
\text { campaign started "Más } \\
\text { vale saber. Educacion de } \\
\text { Bolsillo and a Decree } \\
\text { created the Financial } \\
\text { Education Week to be } \\
\text { celebrated every year. } \\
\text { Both will include fairs } \\
\text { and seminars for the } \\
\text { general public. }\end{array}$ & $\begin{array}{l}2 \text { PLANEF has defined } \\
\text { target groups based on } \\
\text { the Financial Education } \\
\text { Diagnosis and demand } \\
\text { studies. The proposed } \\
\text { target groups are: } \\
\text { students of basic } \\
\text { education and } \\
\text { universities and technical } \\
\text { institutes, vulnerable } \\
\text { populations, micro } \\
\text { entrepreneurs and } \\
\text { workers. Some initiatives } \\
\text { focus on the general } \\
\text { population (such as } \\
\text { awareness campaigns). }\end{array}$ & $\begin{array}{l}1 \text { Central Bank's efforts } \\
\text { are either directed to } \\
\text { the general public, or } \\
\text { to children and young } \\
\text { people. The BCU } \\
\text { creates strategic } \\
\text { alliances with public } \\
\text { and private institutions } \\
\text { of education. }\end{array}$ \\
\hline $\begin{array}{l}2 \mathrm{~B} \text {. } \\
\text { Direct Access to } \\
\text { Products }\end{array}$ & $\begin{array}{l}2 \text { In } 2017 \text { the National } \\
\text { Social Security } \\
\text { Administration and } \\
\text { Banco Macro reached } \\
\text { an agreement to } \\
\text { provide workshops on } \\
\text { financial education for } \\
\text { retirees and recepeints } \\
\text { of the Asignación } \\
\text { Universal por Hijo }\end{array}$ & $\begin{array}{l}2 \text { The National Strategy } \\
\text { targets women } \\
\text { beneficiaries of Bolsa } \\
\text { Familia and actively } \\
\text { promotes financial } \\
\text { education amongst } \\
\text { them. Beneficiaries } \\
\text { receive information on } \\
\text { the advantages of } \\
\text { receiving money in } \\
\text { bank accounts, as well } \\
\text { as in person talks. } \\
\text { Furthermore, they also } \\
\text { receive information on } \\
\text { management of } \\
\text { personal finance. }\end{array}$ & $\begin{array}{l}2 \text { Recipients of social } \\
\text { benefits that apply for } \\
\text { the opening of a } \\
\text { CuentaRUT to receive } \\
\text { their benefits under the } \\
\text { program Chile Cuenta, } \\
\text { receive some financial } \\
\text { education on how to use } \\
\text { the account, card, ATMs. } \\
\text { This is conducted in a } \\
\text { BancoEstado branch. } \\
\text { Since } 2011 \text { training was } \\
\text { included for a pilot } \\
\text { beneficiary group of the } \\
\text { Programa Aborro }\end{array}$ & $\begin{array}{l}2 \text { In } 2008 \text { the } \\
\text { Government } \\
\text { launched a pilot } \\
\text { program of financial } \\
\text { education for the } \\
\text { promotion of savings } \\
\text { behaviour for } \\
\text { recipients of cash } \\
\text { transfers. Since 2014, } \\
\text { the strategy "Colombia } \\
\text { Lista" seeks to } \\
\text { enhance financial } \\
\text { education for } \\
\text { recipients of social } \\
\text { benefits. }\end{array}$ & $\begin{array}{l}2 \text { There are targeted } \\
\text { financial education efforts } \\
\text { for beneficiaries of the } \\
\text { Prospera programme. } \\
\text { This includes conferences } \\
\text { on how and where } \\
\text { account and cardholders } \\
\text { can use these instruments. } \\
\text { Furthermore, Bansefi } \\
\text { offers workshops and } \\
\text { educational materials on } \\
\text { financial planning, } \\
\text { financial services, credit } \\
\text { administration and } \\
\text { remittances. }\end{array}$ & $\begin{array}{l}2 \text { The BCP and the } \\
\text { Ministry of Social Affairs } \\
\text { collaborate to help } \\
\text { improve the financial } \\
\text { literacy of beneficiaries } \\
\text { of Tekopora, which } \\
\text { receive their transfers via } \\
\text { accounts held at the } \\
\text { public bank BNF. The } \\
\text { capacity building is } \\
\text { provided by a leading } \\
\text { international NGO and } \\
\text { aims to foster savings } \\
\text { and help beneficiaries } \\
\text { understand financial } \\
\text { products and services }\end{array}$ & $\begin{array}{l}2 \text { Financial education is } \\
\text { integrated into various } \\
\text { social protection } \\
\text { programs, such as Juntos. } \\
\text { For example, municipal } \\
\text { government staff are } \\
\text { trained to distribute } \\
\text { financial education as } \\
\text { part of economic and } \\
\text { social development } \\
\text { programs. Existing } \\
\text { efforts include } \\
\text { workshops on the use of } \\
\text { cards and on personal } \\
\text { finance management and } \\
\text { entrepreneurship. }\end{array}$ & $\begin{array}{l}0 \text { There is no } \\
\text { information about the } \\
\text { existence of financial } \\
\text { education strategies on } \\
\text { welfare programs such } \\
\text { as the distribution of } \\
\text { conditional cash } \\
\text { transfers through } \\
\text { simplified accounts. }\end{array}$ \\
\hline $\begin{array}{l}2 \mathrm{C} \text {. } \\
\text { Convenience }\end{array}$ & $\begin{array}{l}1 \text { Main channels used are } \\
\text { fairs and seminars, } \\
\text { websites and } \\
\text { educational material for } \\
\text { children and teachers. } \\
\text { There is no policy in } \\
\text { place for the } \\
\text { promotion of financial } \\
\text { education using mass } \\
\text { media, such as TV or } \\
\text { radio, or social } \\
\text { networks. }\end{array}$ & $\begin{array}{l}2 \text { The ENEF promoted } \\
\text { different delivery } \\
\text { channels, widely used } \\
\text { by public authorities: } \\
\text { websites, apps, } \\
\text { audiovisual material; } \\
\text { contents in social } \\
\text { networks; seminars and } \\
\text { other events; } \\
\text { educational material; } \\
\text { and training. }\end{array}$ & $\begin{array}{l}2 \text { Public authorities mainly } \\
\text { use: websites, audiovisual } \\
\text { material, seminars and } \\
\text { other events; and } \\
\text { training. Central Bank } \\
\text { also uses innovative } \\
\text { channels (social } \\
\text { networks, plays for } \\
\text { children and display of } \\
\text { posters in the subway), } \\
\text { and direct visits to target } \\
\text { groups. }\end{array}$ & $\begin{array}{l}2 \text { Public authorities } \\
\text { mainly use seminars, } \\
\text { talks, educational } \\
\text { material, videos and } \\
\text { other activities. A } \\
\text { Banca de Oportunidades } \\
\text { program aims to use } \\
\text { alternative, mass } \\
\text { media channels: social } \\
\text { networks, TV, radio }\end{array}$ & $\begin{array}{l}2 \text { The Financial Inclusion } \\
\text { Strategy promotes the use } \\
\text { of alternative channels. } \\
\text { Public authorities mainly } \\
\text { use: seminars and talks, } \\
\text { educational material } \\
\text { public websites; plays for } \\
\text { children, prizes and } \\
\text { competitions, and Banco } \\
\text { de Mexico's interactive } \\
\text { museum }\end{array}$ & $\begin{array}{l}1 \text { Channels used by public } \\
\text { authorities are: training, } \\
\text { information brochures } \\
\text { and flyers, as well as } \\
\text { mass media (TV and } \\
\text { radio). However, so far } \\
\text { use of mass media for } \\
\text { financial education } \\
\text { purposes has been } \\
\text { limited. Information is } \\
\text { distributed in all official } \\
\text { languages. }\end{array}$ & $\begin{array}{l}2 \text { The National Financial } \\
\text { Education Plan shows } \\
\text { the intention to use } \\
\text { various channels, } \\
\text { leveraging technologies } \\
\text { to improve reach and use } \\
\text { innovative approaches } \\
\text { such as SMS text } \\
\text { messaging, or radio. }\end{array}$ & $\begin{array}{l}2 \text { The BCU has two } \\
\text { webistes for financial } \\
\text { education: "BCU } \\
\text { Educa", and "Usuario } \\
\text { Financiero". The BCU } \\
\text { also uses television } \\
\text { programs and face-to- } \\
\text { face courses in schools } \\
\text { to disseminate the } \\
\text { financial education } \\
\text { program. }\end{array}$ \\
\hline $\begin{array}{l}\text { Financial Literacy } \\
\text { Sub-Index Score }\end{array}$ & 0.9 & 2 & 1.3 & 1.5 & 1.5 & 0.9 & 2 & 8 \\
\hline
\end{tabular}




\section{Annex XV: Financial Transaction Taxes: Summary of Regulatory Findings}

\begin{tabular}{|c|c|c|c|c|c|c|c|c|}
\hline Criteria/ Country & Argentina & Brazil & Chile & Colombia & Mexico & Paraguay & Peru & Uruguay \\
\hline $\begin{array}{l}\text { 1. Unadjusted Financial } \\
\text { Transaction Tax }\end{array}$ & $\begin{array}{l}0 \text { In Argentina a financial } \\
\text { transaction tax exists } \\
\text { which taxes both credit } \\
\text { and debit in bank } \\
\text { accounts and other } \\
\text { operations. General } \\
\text { rates move between } \\
0.25 \% \text { and } 1.2 \% \text {. }\end{array}$ & $\begin{array}{l}0 \text { Brazil has employed } \\
\text { two different taxes, } \\
\text { one on bank debit } \\
\text { (CPMF), currently not } \\
\text { in force, and one on } \\
\text { financial operations } \\
\text { (foreign exchange, } \\
\text { insurance, credit), the } \\
\text { IOF, in force. Both } \\
\text { distort financial } \\
\text { intermediation, } \\
\text { although the IOF is } \\
\text { more punitive on } \\
\text { credit. }\end{array}$ & $\begin{array}{l}0 \text { In Chile a financial } \\
\text { transaction exists (the seal } \\
\text { and stamp tax) which } \\
\text { stipulates a rate of } \\
0.066 \% \text { per month (with } \\
\text { a maximum } 0.8 \% \\
\text { annually) on every credit } \\
\text { operation. }\end{array}$ & $\begin{array}{l}\mathbf{0} \text { The Colombian bank } \\
\text { debit tax, commonly } \\
\text { known as } 4 \times 1000 \text {, is in } \\
\text { force since } 1998 \text {. The } \\
2016 \text { tax reform has } \\
\text { stopped the } \\
\text { progressive elimination } \\
\text { of the tax that had } \\
\text { been agreed in } \\
\text { previous reforms } \\
\text { (2010 and 2014), and } \\
\text { therefore the tax is } \\
\text { now considered } \\
\text { permanent }\end{array}$ & $\begin{array}{l}0 \text { Mexico levies a tax } \\
(3 \%) \text { on all cash } \\
\text { deposits in any } \\
\text { account owned by } \\
\text { natural or legal } \\
\text { persons that exceed } \\
15000 \text { Mexican pesos. } \\
\text { The amount paid for } \\
\text { this tax can be fully } \\
\text { credited against the } \\
\text { personal income tax. }\end{array}$ & $\begin{array}{l}2 \text { There is not a financial } \\
\text { transaction tax in force }\end{array}$ & $\begin{array}{l}\mathbf{0} \text { The Peruvian Financial } \\
\text { Transaction Tax } \\
\text { became a permanent } \\
\text { instrument in 2004. It } \\
\text { charges a } 0.005 \% \text { rate } \\
\text { on all credit and debit } \\
\text { operations. }\end{array}$ & $\begin{array}{l}2 \text { There is not a financial } \\
\text { transaction tax in force }\end{array}$ \\
\hline $\begin{array}{l}\text { 1A. } \\
\text { Adjustment for fiscal } \\
\text { deductions }\end{array}$ & $\begin{array}{l}\text {-- The IOF payment } \\
\text { cannot be fully } \\
\text { deducted against the } \\
\text { payment of other taxes }\end{array}$ & $\begin{array}{l}\text {-- The IOF payment } \\
\text { cannot be deducted } \\
\text { against the payment of } \\
\text { other taxes }\end{array}$ & $\begin{array}{l}\text {-- The amount paid on this } \\
\text { tax cannot be deducted/ } \\
\text { credited against the } \\
\text { payment of other taxes. }\end{array}$ & $\begin{array}{l}\text {-- The amount paid on } \\
\text { this tax cannot be } \\
\text { deducted/ credited } \\
\text { against the payment } \\
\text { of other taxes. }\end{array}$ & $\begin{array}{l}0.5 \text { The amount paid for } \\
\text { this tax can be fully } \\
\text { credited against the } \\
\text { personal income tax. }\end{array}$ & $\begin{array}{l}\text { n.a. There is not a financial } \\
\text { transaction tax in force }\end{array}$ & $\begin{array}{l}0.5 \text { The amounts paid for } \\
\text { the tax can be fully } \\
\text { deducted for the } \\
\text { personal income tax }\end{array}$ & $\begin{array}{l}\text { n.a. There is not a financial } \\
\text { transaction tax in force }\end{array}$ \\
\hline $\begin{array}{l}\text { 1B. } \\
\text { Adjustment for } \\
\text { exceptions in payment } \\
\text { of tax }\end{array}$ & $\begin{array}{l}0.5 \text { Credits and debits on } \\
\text { cajas de aborros } \\
\text { (simplified accounts) } \\
\text { are exempt from the } \\
\text { tax. }\end{array}$ & $\begin{array}{l}\text {-- No relevant } \\
\text { exemptions }\end{array}$ & -- No relevant exemptions & $\begin{array}{l}0.5 \text { Each individual can } \\
\text { have own one } \\
\text { financial instrument } \\
\text { exempt from the } \\
4 \times 1000 \text {. Also, } \\
\text { products aimed to } \\
\text { promote financial } \\
\text { inclusion are exempt. }\end{array}$ & $\begin{array}{l}0.5 \text { The tax is only } \\
\text { imposed on cash } \\
\text { deposits that exceed } \\
15000 \text { Mexican pesos }\end{array}$ & $\begin{array}{l}\text { n.a. There is not a financial } \\
\text { transaction tax in force }\end{array}$ & $\begin{array}{c}\text { - No relevant } \\
\text { exemptions }\end{array}$ & $\begin{array}{l}\text { n.a. There is not a financial } \\
\text { transaction tax in force }\end{array}$ \\
\hline $\begin{array}{l}\text { 1C. } \\
\text { Adjustment for close to } \\
\text { zero tax rate }\end{array}$ & $\begin{array}{l}-- \text { The tax rates depend on } \\
\text { the financial transaction } \\
\text { (rank between } 0.05 \% \\
\text { and } 1.2 \% \text { ) }\end{array}$ & $\begin{array}{l}\text {-- The tax rates depend } \\
\text { on the financial } \\
\text { transaction. The tax } \\
\text { rate for credit } \\
\text { operations is } 3 \%\end{array}$ & $\begin{array}{l}\text {-- The tax charges a rate of } \\
0.066 \% \text { per month (with } \\
\text { a maximum } 0.8 \% \\
\text { annually) on every credit } \\
\text { operation. }\end{array}$ & -- The tax rate is $0.4 \%$ & $\begin{array}{l}- \text { The tax rate is } 3 \% \text { of } \\
\text { the deposits over } \\
15000 \text { Mexican pesos }\end{array}$ & $\begin{array}{l}\text { n.a. There is not a financial } \\
\text { transaction tax in force }\end{array}$ & $\begin{array}{l}0.5 \text { It charges a } 0.005 \% \\
\text { rate on all credit and } \\
\text { debit operations. }\end{array}$ & $\begin{array}{l}\text { n.a. There is not a financial } \\
\text { transaction tax in force }\end{array}$ \\
\hline $\begin{array}{l}\text { Adjusted Financial } \\
\text { Transaction Tax Sub- } \\
\text { Index Score }\end{array}$ & 0.5 & 0 & 0 & 0.5 & 1 & 2 & 1 & 2 \\
\hline
\end{tabular}




\section{Annex XVI: Financial Transaction Taxes in Brazil ${ }^{97}$}

Over time, Brazil has introduced two different financial transaction taxes.

\section{Contribucao provisoria sobre movimentacao ou trasmissao de valores e de creditos e direitos de natureza financiera (CPMF).}

This tax on bank debit was first introduced in 1993 (originally called Imposto Provisorio sobre a Movimentacao Financeira - IPMF). After it was revoked, Law 9.311 from October 1996 reintroduced the tax, now under the name: Contribucao provisoria sobre movimentacao ou trasmissao de valores e de creditos e direitos de natureza financiera (CPMF).

The rate was set at 0.2 percent $^{98}$ and it was originally earmarked to finance health care programs, to combat poverty and for social assistance. The tax rate was raised several times, and it was set at 0.38 percent by the time it was revoked in 2007 .

Table 1. CPMF Tax Rates

\begin{tabular}{ll}
$\begin{array}{l}\text { Tax } \\
\text { Rate }\end{array}$ & Period \\
\hline $\mathbf{0 . 2 5}$ & $\begin{array}{l}\text { 26 August } 1993 \text { to 15 September 1993; 1 January 1994 to } 31 \\
\text { December 1994 }\end{array}$ \\
\hline $\mathbf{0 . 2 0}$ & 23 January 1997 to 22 January 1999 \\
\hline $\mathbf{0 . 3 8}$ & 17 June 1999 to 16 June 2000 \\
\hline $\mathbf{0 . 3 0}$ & 17 June 2000 to 17 March 2001 \\
\hline $\mathbf{0 . 3 8}$ & From 18 March 2001 until the tax was revoked
\end{tabular}

Source. Baca-Campodónico, et al (2006) and relevant legislation

The tax levied all debits by non-bank depositors from current, investment, time deposit and savings accounts, including overdraft facilities in current accounts and transactions in derivatives. Government accounts (all levels of governments, including government agencies) were exempt, as well as withdrawals from individual social security accounts and unemployment insurance. Non-profit organizations were also exempt from CPMF taxation.

This tax has been officially revoked since 2007. However, over the past year the potential reintroduction of the CPMF has been present in the media. This measure was already

\footnotetext{
97: Unless stated otherwise, information was obtained from: Penido do Freitas et.al. (2013)

98: The tax rate of the original IMPF was 0.25 percent, but it was lowered to 0.2 percent when the CPMF was created.
} 
brought forward by the Government in 2015, but it has not been discarded by the current Minister of Finance, Henrique Meirelles. The rapporteur of the Budgetary Law for 2017 has declared that potential tax revenues from the CPMF will not be included in the 2017 Budget unless the Constitution is amended first. ${ }^{99}$

\section{The effects of the CPMF:}

On the effects of the CPMF, Baca-Campodónico, et al (2006) identified that the tax promoted some financial disintermediation in Brazil (measured as the ratio of cash out of banks to banks' liquid assets) as the statutory CPMF rate was increased. Furthermore, Koyama and Nakane (2001) showed that the Brazilian bank debit tax (CPMF) was associated with a fall in the number of issued checks, a small increase in M1, a shift in portfolio allocation from term deposits in favor of investment funds, and an increase in interest spreads

This is consistent with the results obtained by Albuquerque (2001), Singh et al (2005) and Coelho et al (2001). Furthermore, Coelho et al (2001) also found that the bulk of the revenue raised from the CPMF seemed to be coming from basic financial transactions (such as checks paid for consumption or business purposes) rather than from investment transactions and complex financial operations.

\section{Imposto Transaccoes Financieras (IOF).}

The Tax on Financial Transactions (IOF for its acronym in Portuguese) was first created in 1966, as an auxiliary monetary policy instrument.

The IOF is levied on credit (including intercompany loans), foreign exchange operations, insurance and securities transactions. The tax also applies to transactions in gold or involving gold. The tax base varies depending on the taxable event and the financial nature of the transaction, and rates vary depending on the financial transaction.

Under the Brazilian Constitution most taxes can only be increased by law approved by the National Congress and usually take effect after ninety days. However, the IOF is an exception, as its management rests with the Executive Power, through the Finance Ministry, and can be modified at any time by Decree without Congressional ratification. Any change introduced may become effective immediately from its enactment date. Because of the above, the rates levied for the financial transactions tax have changed repeatedly over time, although within certain limits provided by the law. In fact, in several occasions the tax rates for the IOF have been raised to compensate for a fall in fiscal revenues brought forward by the suspension of the CPMF (see below more information on the evolution of the IOF).

\footnotetext{
99: The Brazilian Banking Association (Febraban) has declared that it supports the reintroduction of the CPMF, as a rapid way to boost public finances. However, the association insisted in the need of a temporary introduction, which should be accompanied by a progressive phase-out of the tax.
} 
Exemptions from the IOF include: credit transactions carried out by state-owned financing company FINEP; credit transactions made by the state-owned financing agency FINAME; and purchases of foreign currency by Brazilian banks as well as simultaneous exchange transactions. Credit transactions by Brazil's National Bank for Economic and Social Development or its agents used to be exempt of the tax, but a Decree that entered into force in September 2015 eliminated this exemption (Decree 8511/2015).

\section{Recent evolution of the IOF}

In 2008, to stem the outflow of investment and counteract the effects of the global financial crisis, the Brazilian government eliminated the IOF. With the resumption of massive capital inflows, capital controls were imposed again as early as February of 2009. In October 2009, Brazilian authorities expanded the IOF tax to a 2 percent rate on fixed income, in addition to portfolio and equity investments, and increased the rate to 0.38 percent on most foreign exchange operations. Besides the strong appreciation of the Brazilian real, the other driver of the increases in the IOF rate is the end of the CPMF in 2008. The lack of the associated tax revenue led the government to increase the IOF rate.

Since its re-introduction in October 2009, the IOF tax was repeatedly raised and expanded to include other forms of investments by the Brazilian government to control the influx of foreign capital. In 2010, the IOF rate was raised to 6 percent. In 2013, the Brazilian Government decided to cut the IOF from 6 percent to zero, amid concerns that the Brazilian Real was weakening too quickly against the dollar.

In 2015, the Government decided to raise the IOF on credit operations from 1.5 percent to 3 percent, in an attempt to increase revenues collected. This has significantly increased the cost of credit.

Table 2. Current IOF rates:

\section{Type of operation $\quad$ IOF Rate}

Credit, natural persons $\quad 3 \%$ on a yearly basis

Opening of credit $\quad 0.38 \%$

Foreign exchange $\quad$ Maximum 25\%

\begin{tabular}{ll}
\hline Insurance & Maximum 25\%
\end{tabular}

Equity and real estate $\quad 1.5 \%$, daily basis

Source: Decree 6306/2007 and amendments

\section{The effects of the IOF:}

The National Association of Executives for Finance, Adminsitration and Accounting (ANAFEC), has performed several simulations on the effects of the IOF on the cost of 
credit. By the time of its reintroduction, back in 2008, ANAFEC stated that the increase in the cost of credit caused by the introduction of the IOF was larger than the savings allowed by the elimination of the CPMF. Furthermore, ANAFEC also reiterated that the increase in the rate for credit in 2015 (from 1.5 percent to 3 percent) would increase the cost of short term credit, ${ }^{100}$ especially affecting consumer decisions.

100: The increase only affected credit with maturities up to one year. 


\section{Annex XVII: Interest Rates Ceilings: Summary of Regulatory Findings}

\begin{tabular}{|c|c|c|c|c|c|c|c|c|}
\hline Criteria/ Country & Argentina & Brazil & Chile & Colombia & Mexico & Paraguay & Peru & Uruguay \\
\hline $\begin{array}{l}\text { Interest rate } \\
\text { ceilings }\end{array}$ & $\begin{array}{l}1 \text { Compensatory interest } \\
\text { rates are freely agreed } \\
\text { between financial } \\
\text { institutions and clients, } \\
\text { with the exception of } \\
\text { financing related to } \\
\text { credit cards } \\
\text { transactions. } \\
\text { In this case, the limit of } \\
\text { compensatory interest } \\
\text { shall not exceed more } \\
\text { than } 25 \% \text { of the rate } \\
\text { resulting from the } \\
\text { average interest rates } \\
\text { that the entity applied } \\
\text { during the previous } \\
\text { month. According to } \\
\text { local experts, these rates } \\
\text { are below market rates } \\
\text { for some segments of } \\
\text { borrowers, who might } \\
\text { end up without access } \\
\text { to credit. Also, directed } \\
\text { lending programs } \\
\text { mandate banks to } \\
\text { allocate a percentage of } \\
\text { their deposits to credit } \\
\text { to predefined sectors } \\
\text { and SMEs at rates } \\
\text { below a fixed rate set by } \\
\text { the Central Bank also } \\
\text { generate distortions in } \\
\text { credit markets. Still, } \\
\text { recent Government } \\
\text { policies are moving in } \\
\text { the right direction. }\end{array}$ & $\begin{array}{l}0 \text { Interest rates for not } \\
\text { directed credit are } \\
\text { determined freely } \\
\text { under market } \\
\text { conditions. However, } \\
\text { interest rates on credit } \\
\text { with the so-called } \\
\text { recursos direcionados } \\
\text { (related to agriculture, } \\
\text { real estate and } \\
\text { microcredit) are } \\
\text { subject to caps. This } \\
\text { has been found to } \\
\text { create important } \\
\text { distortions and drive } \\
\text { up the price of credit. }\end{array}$ & $\begin{array}{l}0 \text { There is a limit on interest } \\
\text { rates on consumer credit, } \\
\text { set at } 150 \% \text { of current } \\
\text { interest rates, although the } \\
\text { Law differentiates } \\
\text { depending on the amount } \\
\text { of the loans. A reform } \\
\text { introduced in } 2013 \text { to } \\
\text { reduce the maximum } \\
\text { interest rates charged for } \\
\text { low-value loans has been } \\
\text { found to restrict access to } \\
\text { credit for low income } \\
\text { population, according to } \\
\text { studies by SBIF and } \\
\text { ABIF. }\end{array}$ & $\begin{array}{l}0 \text { There is a limit on } \\
\text { interest rates, set at } 1.5 \\
\text { times the moving } \\
\text { average of interest } \\
\text { rates charged by banks. } \\
\text { The limit is calculated } \\
\text { for three categories of } \\
\text { credit: consumption } \\
\text { credit, microcredit and } \\
\text { smaller consumption } \\
\text { loans (credito al consumo } \\
\text { de bajo monto). The } \\
\text { methodology for the } \\
\text { calculation was } \\
\text { amended in } 2010 \text { to } \\
\text { better reflect market } \\
\text { rates. This has been } \\
\text { found to benefit } \\
\text { financial inclusion and } \\
\text { access to credit. } \\
\text { However, according to } \\
\text { a } 2016 \text { study from } \\
\text { Anif, the cap still } \\
\text { restricts access to } \\
\text { credit for low income } \\
\text { population. }\end{array}$ & $\begin{array}{l}2 \text { There are no interest } \\
\text { rate ceilings. The } \\
\text { Financial Services } \\
\text { Transparency and } \\
\text { Regulation Law allows } \\
\text { the Central Bank to } \\
\text { set limits to interest } \\
\text { rates, but the Bank has } \\
\text { not exercised this } \\
\text { power so far. }\end{array}$ & $\begin{array}{l}1 \text { There is a limit on interest } \\
\text { rates for loans, set at } 130 \% \\
\text { of a moving average of } \\
\text { consumer lending rates. } \\
\text { According to a } 2014 \text { World } \\
\text { Bank report, financial } \\
\text { institutions in Paraguay } \\
\text { found that this limit allows } \\
\text { them to cover the costs of } \\
\text { providing credit, even in } \\
\text { the case of microfinance } \\
\text { loans. However, in } 2015 \text { a } \\
\text { regulation entered into } \\
\text { force that creates a limit to } \\
\text { the interest rate on credit } \\
\text { cards. According to the } \\
\text { Central Bank and market } \\
\text { participants, this has lead } \\
\text { to a fall in the number of } \\
\text { credit cards. }\end{array}$ & $\begin{array}{l}2 \text { There are no interest } \\
\text { rate ceilings, but Law } \\
26.123 \text { allows the } \\
\text { Central Bank to set } \\
\text { maximum interest rates } \\
\text { if deemed necessary. } \\
\text { This has not been } \\
\text { implemented in } \\
\text { practice }\end{array}$ & $\begin{array}{l}0 \text { Law } 18.212 / 2007 \text { sets } \\
\text { the limit on interest } \\
\text { rates for loans of less } \\
\text { than } 2 \text { million UI at } \\
55 \% \text { above average } \\
\text { market rates, and for } \\
\text { loans greater than } 2 \\
\text { million UI at } 90 \% \\
\text { above average market } \\
\text { rates. The limit imposed } \\
\text { for smaller loans seems } \\
\text { to distort the market, as } \\
\text { it is calculated by the } \\
\text { Central Bank using } \\
\text { information from } \\
\text { financial intermediation } \\
\text { institutions. This results } \\
\text { in a ceiling that is not } \\
\text { representative of } \\
\text { microfinance activities }\end{array}$ \\
\hline $\begin{array}{l}\text { Interest rate } \\
\text { ceilings Sub- } \\
\text { Index Score }\end{array}$ & 1 & 0 & 0 & 0 & 2 & 1 & 2 & 0 \\
\hline
\end{tabular}




\section{Annex XVIII: Directed Lending: Summary of Regulatory Findings}

\begin{tabular}{|c|c|c|c|c|c|c|c|c|}
\hline Criteria/ Country & Argentina & Brazil & Chile & Colombia & Mexico & Paraguay & Peru & Uruguay \\
\hline Directed Lending & $\begin{array}{l}0 \text { The Government } \\
\text { significantly influences } \\
\text { the allocation of credit. } \\
\text { Argentina has both } \\
\text { directed lending } \\
\text { programs, that force } \\
\text { some financial } \\
\text { institutions to invest in } \\
\text { particular sectors, } \\
\text { especially those related } \\
\text { with SMEs and } \\
\text { productive projects, and } \\
\text { also state bank lending } \\
\text { though several state } \\
\text { banks. }\end{array}$ & $\begin{array}{l}0 \text { Approximately } 42 \% \text { of } \\
\text { Brazilian credit falls } \\
\text { under the category } \\
\text { credito direcionado and } \\
\text { regulated interest rates } \\
\text { are used on } 86 \% \text { of } \\
\text { the total directed } \\
\text { credit. This credit } \\
\text { comes mainly from } \\
\text { the national } \\
\text { development bank } \\
\text { (BNDES), the Rural } \\
\text { Credit National } \\
\text { System (SNCR) and } \\
\text { the Housing National } \\
\text { System (SNH). } \\
\text { Furthermore, the } \\
\text { national development } \\
\text { bank conducts both } \\
\text { first and second tier } \\
\text { lending. }\end{array}$ & $\begin{array}{l}2 \text { Quantitative limits } \\
\text { governing credit } \\
\text { allocation by banks were } \\
\text { revoked in } 1973 \text {. } \\
\text { Furthermore, as a result } \\
\text { of the financial reforms } \\
\text { carried out in the } 70 \text { s, the } \\
\text { only remaining public } \\
\text { bank in Chile is Banco Del } \\
\text { Estado. It competes as a } \\
\text { first-tier bank with private } \\
\text { commercial banks, and } \\
\text { there is no evidence of } \\
\text { political interference in its } \\
\text { activities, although it has a } \\
\text { social role. }\end{array}$ & $\begin{array}{l}0 \text { Regulation mandates } \\
\text { private institutions to } \\
\text { invest a percentage of } \\
\text { their resources in a } \\
\text { second-tier public bank } \\
\text { (Finagro). These } \\
\text { resources are then used } \\
\text { to provide agricultural } \\
\text { loans at interest rates } \\
\text { set by the authorities. } \\
\text { Banks are allowed to } \\
\text { substitute the } \\
\text { mandatory investments } \\
\text { in Finagro with credit } \\
\text { granted directly to the } \\
\text { agricultural sector with } \\
\text { their own resources. } \\
\text { As a result, smaller } \\
\text { producers get excluded } \\
\text { from formal credit. }\end{array}$ & $\begin{array}{l}2 \text { Development banking } \\
\text { institutions in Mexico } \\
\text { are regulated under } \\
\text { the Credit Institutions } \\
\text { Law. Development } \\
\text { banks conduct their } \\
\text { operations through } \\
\text { second-tier credit. } \\
\text { This has not been } \\
\text { found to create } \\
\text { distortions in credit } \\
\text { markets (GFDR } \\
\text { 2013). }\end{array}$ & $\begin{array}{l}0 \text { First-tier public institutions } \\
\text { have benefited from } \\
\text { preferential treatment by } \\
\text { the Government, which } \\
\text { might have induced a lax } \\
\text { credit risk assessment. } \\
\text { Additionally, governance } \\
\text { structures suggest } \\
\text { significant Government } \\
\text { interference and in some } \\
\text { cases, first-tier institutions } \\
\text { are catering sectors which } \\
\text { are already served by the } \\
\text { private sector. These } \\
\text { features have been found } \\
\text { to generate distortions. }\end{array}$ & $\begin{array}{l}2 \text { Banco de la Nación and } \\
\text { Banco Agropecuario act as } \\
\text { first and second tier } \\
\text { institutions. In } \\
\text { particular, Banco } \\
\text { Agropecuario's objectives } \\
\text { include granting first } \\
\text { tier credit for small and } \\
\text { medium producers. } \\
\text { Still, they represent a } \\
\text { minimum share of the } \\
\text { market, and their } \\
\text { activities are not } \\
\text { perceived as } \\
\text { distortionary by market } \\
\text { participants. }\end{array}$ & $\begin{array}{l}0 \text { The state significantly } \\
\text { influences the allocation } \\
\text { of credit. According to } \\
\text { the latest FSAP } \\
\text { conducted by the IMF } \\
\text { on Uruguay (2013), } \\
\text { state banks (Banco de la } \\
\text { Repriblica Orienta de } \\
\text { Uruguay and Banco } \\
\text { Hipotecario de Urugualy } \\
\text { have an explicit } \\
\text { unlimited and } \\
\text { permanent deposit } \\
\text { guarantee, providing } \\
\text { them with a competitive } \\
\text { advantage. } \\
\text { Also, BROU enjoys } \\
\text { special authorization to } \\
\text { directly debit payrolls to } \\
\text { service outstanding } \\
\text { loans, thus reducing } \\
\text { credit risk. }\end{array}$ \\
\hline $\begin{array}{l}\text { Directed Lending } \\
\text { Sub-Index Score }\end{array}$ & 0 & 0 & 2 & 0 & 2 & 0 & 2 & 0 \\
\hline
\end{tabular}




\section{Abbreviations}

\begin{tabular}{|c|c|}
\hline $\mathrm{ABIF}$ & Asociación de Bancos e Instituciones Financieras de Chile \\
\hline AML/CFT & $\begin{array}{l}\text { Anti-Money Laundering/Combating the Financing of } \\
\text { Terrorism }\end{array}$ \\
\hline ANIF & $\begin{array}{l}\text { Asociación Nacional de Instituciones Financieras de } \\
\text { Colombia }\end{array}$ \\
\hline ARS & Peso Argentino \\
\hline ASBA & Asociación de Supervisores Bancarios de las Américas \\
\hline ATM & Automated Teller Machine \\
\hline AUH & Asignación Universal por Hijo \\
\hline Bansefi & Banco del Aborro Nacionaly Servicios Financieros \\
\hline BCB & Banco Central do Brasil \\
\hline BCBS & Basel Committee on Banking Supervision \\
\hline BCP & Banco Central del Paraguay \\
\hline BCRA & Banco Central de la República Argentina \\
\hline BCU & Banco Central de Uruguay \\
\hline BIS & Bank. for International Settlements \\
\hline BNDES & $\begin{array}{l}\text { Banco Nacional de Desenvolvimento Econômico e Social do } \\
\text { Brasil }\end{array}$ \\
\hline BNF & Banco Nacional de Fomento de Paraguay \\
\hline BROU & Banco de la República Oriental de Uruguay \\
\hline CAE & Cuenta de Ahorro Electrónica \\
\hline CAF & Corporación Andina de Fomento \\
\hline CAPIF & Comisión Asesora para la Inclusión Financiera de Chile \\
\hline CATS & Cuenta de Ahorro de Trámite Simplificado \\
\hline CBA & Cuenta Básica de Ahorro \\
\hline CDD & Customer Due Diligence \\
\hline CEF & Committee for Financial Education \\
\hline CFT & Counter the Financing of Terrorism \\
\hline CGAP & Consultative Group to Assist the Poor \\
\hline CGD & Center for Global Development \\
\hline
\end{tabular}

\begin{tabular}{|c|c|}
\hline CMACs & Cajas Municipales de Aborro y Crédito \\
\hline CMN & Conselho Monetário Nacional \\
\hline CNBV & Comisión Nacional Bancaria y de Valores de Mexico \\
\hline CNDC & $\begin{array}{l}\text { Comisión Nacional de Defensa de la Competencia de } \\
\text { Argentina }\end{array}$ \\
\hline $\mathrm{CNV}$ & Comisión Nacional de V alores de Argentina \\
\hline COFIDE & Corporación Financiera de Desarrollo \\
\hline CONDUSEF & $\begin{array}{l}\text { Comisión Nacional para Protección y Defensa de los } \\
\text { Usuarios de Servicios Financieros }\end{array}$ \\
\hline COP & Peso Colombiano \\
\hline $\mathrm{CPF}$ & Cadastro de Pessoas Físicas \\
\hline CPMF & $\begin{array}{l}\text { Contribuição Provisória sobre Movimentação } \\
\text { Financeira }\end{array}$ \\
\hline CURP & Clave Única del Registro de Población \\
\hline CVM & Comissão de Valores Mobiliários \\
\hline DNIC & Dirección Nacional de Identificación Civil \\
\hline DSP & Digital Service Provider \\
\hline EDPYME & $\begin{array}{l}\text { Entidad de Desarrollo para la Pequeña y } \\
\text { Microempresa }\end{array}$ \\
\hline EEDE & Empresa Emisora de Dinero Electrónico \\
\hline EIU & Economic Intelligence Unit \\
\hline EMPE & Entidad de Medio de Pago Electrónico \\
\hline ENEF & Estratégia Nacional de Educação Financeira \\
\hline ENIF & Estrategia Nacional de Inclusión Financiera \\
\hline FATF & Financial Action Task Force \\
\hline FEBRABAN & Federação Brasileira de Bancos \\
\hline Finagro & $\begin{array}{l}\text { Fondo para el Financiamiento del Sector } \\
\text { Agropecuario }\end{array}$ \\
\hline FINAME & Agência Especial de Financiamento Industrial \\
\hline FINEP & Financiadora de Estudos e Projetos \\
\hline FOGAFIN & Fondo de Garantías de Instituciones Financieras \\
\hline FOMIN & Fondo Multilateral de Inversiones \\
\hline
\end{tabular}




\begin{tabular}{|c|c|c|c|}
\hline FSAP & Financial Sector Assessment Program & RENIEC & Registro Nacional de Identificación y Estado Civil \\
\hline FSB & Financial Stability Board & RUT & Registro Único Tributario \\
\hline FTT & Financial Transaction Tax & SBIF & $\begin{array}{l}\text { Superintendencia de Bancos e Instituciones } \\
\text { Financieras }\end{array}$ \\
\hline GDP & Gross Domestic Product & SBS & Superintendencia de Banca, Seguros y AFP \\
\hline GFDR & Global Financial Development Report & SCMEPPs & $\begin{array}{l}\text { Sociedades de Crédito ao Microempreendedor e às } \\
\text { Empresas de Pequeno Porte }\end{array}$ \\
\hline GSMA & GSM Association & SEDPE & $\begin{array}{l}\text { Sociedad Especializada en Depósitos y Pagos } \\
\text { Electrónicos }\end{array}$ \\
\hline IADB & Inter-American Development Bank & SEFyC & $\begin{array}{l}\text { Superintendencia de Entidades Financieras y } \\
\text { Cambiarias }\end{array}$ \\
\hline IADI & International Association of Deposit Insurers & SEPRELAD & $\begin{array}{l}\text { Secretaría de Prevención de Lavado de Dinero o } \\
\text { Bienes }\end{array}$ \\
\hline IBFD & International Bureau of Fiscal Documentation & SERNAC & Servicio Nacional del Consumidor \\
\hline ID & Identity Document & SES & Superintendencia de Economía Solidaria \\
\hline ID4D & Identification for Development Database & SFC & Superintendencia Financiera de Colombia \\
\hline IEDE & Institución Emisora de Dinero Electrónico & SHCP & Secretaría de Hacienda y Crédito Público \\
\hline IMF & International Monetary Fund & SMEs & Small and Middle Size Enterprises \\
\hline INCOOP & Instituto Nacional de Cooperativismo & SNCR & Sistema Nacional de Crédito Rural \\
\hline INDECOPI & $\begin{array}{l}\text { Instituto Nacional de Defensa de la Competencia y } \\
\text { de la Protección de la Propiedad Intelectual }\end{array}$ & SOCAP & Sociedades Cooperativas de Ahorro y Préstamo \\
\hline INFE & International Network on Financial Education & SOFIPO & Sociedad Financiera Popular \\
\hline IOF & Imposto sobre Operações Financeiras & SOFOME & Sociedad Financiera de Objeto Múltiple \\
\hline KYC & Know Your Customer & SSF & Superintendencia de Servicios Financieros \\
\hline LIC & Ley de Instituciones de Crédito & TDA & Título de Desarrollo Agropecuario \\
\hline MFA & Más Familias en Acción & UAF & Unidad de Análisis Financiero \\
\hline MFI & Microfinance Institution & UDIS & Unidades de Inversión \\
\hline NGO & Non-Governmental Organizations & UNCTAD & $\begin{array}{l}\text { United Nations Conference on Trade and } \\
\text { Development }\end{array}$ \\
\hline OECD & $\begin{array}{l}\text { Organization for Economic Co-operation and } \\
\text { Development }\end{array}$ & USD & United States Dollars \\
\hline PLANEF & Plan Nacional de Educación Financiera & UYU & Peso Uruguayo \\
\hline PND & Plan Nacional de Desarrollo & & \\
\hline POS & Point Of Sale & & \\
\hline RADIM & Red Argentina de Instituciones de Microcrédito & & \\
\hline RAN & Recopilación Actualizada de Normas & & \\
\hline Renapo & Registro Nacional de Población e Identificación & & \\
\hline
\end{tabular}

